
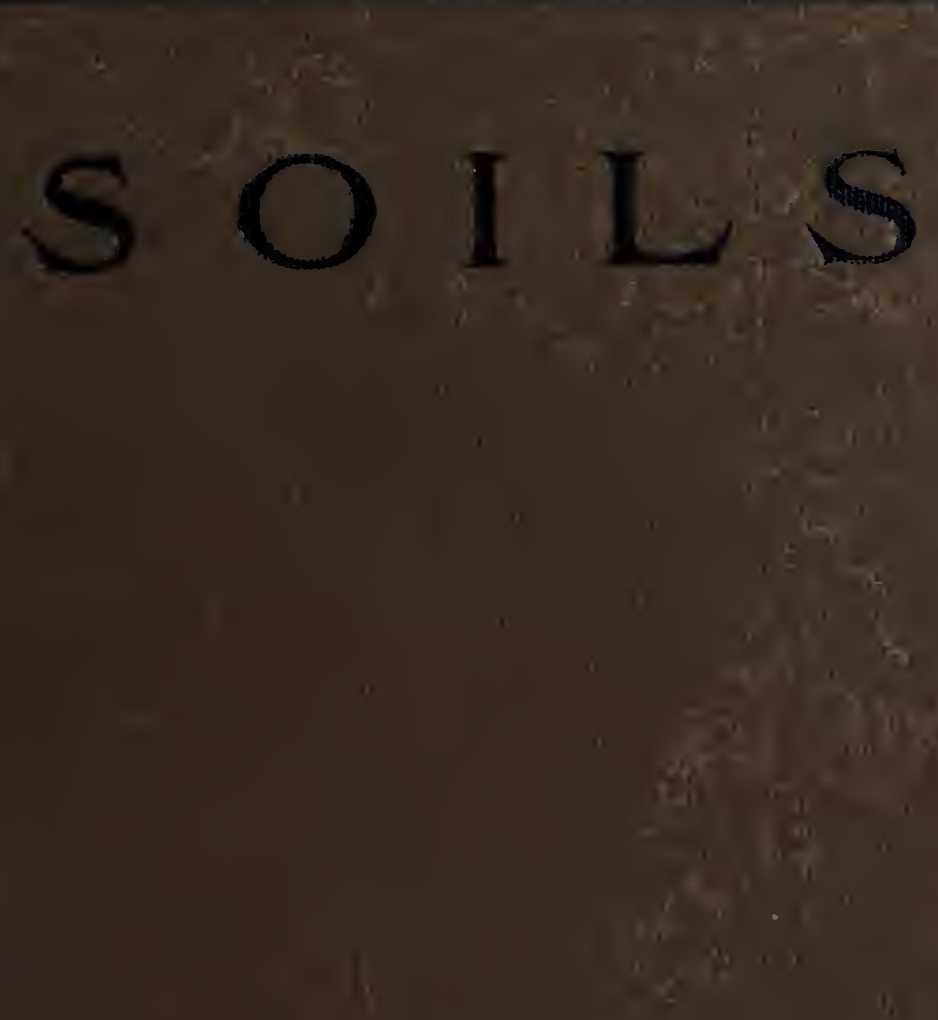

C.W.BURKETT $i^{\prime}$ 


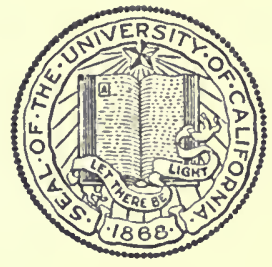

THE LIBRARY

OF

THE UNIVERSITY

OF CALIFORNIA

LOS ANGELES

GIFT OF

Paul Popenoe 
WES'I INIIA GARDENS 


$$
1
$$




\section{Digitized by the Internet Archive}

in 2007 with funding from Microsoft Corporation 


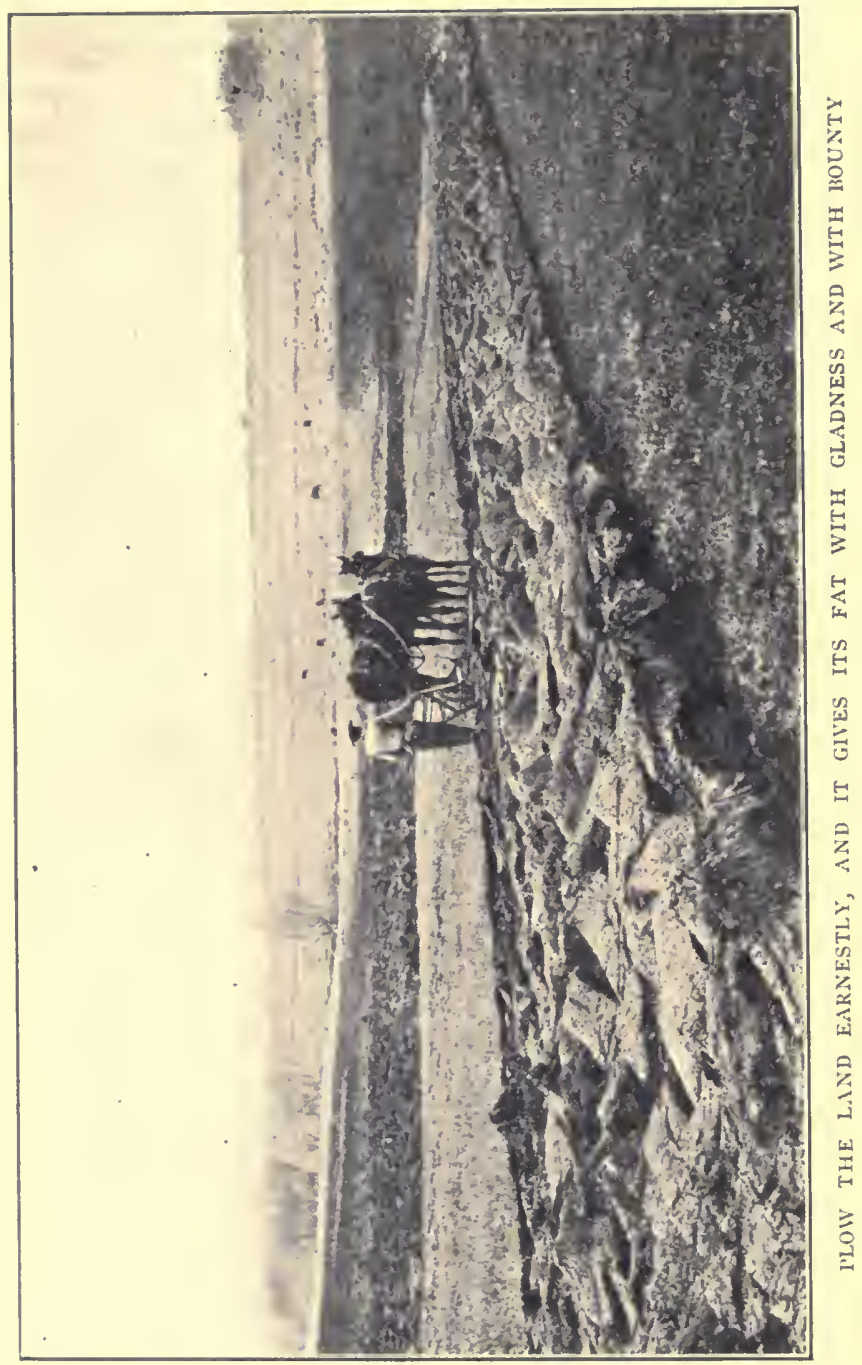




\section{SOILS}

Their Properties, Improvement, Management, and the Problems of Crop Growing and Crop Feeding

\section{By \\ CHARLES WILLIAM BURKETT \\ Director of the Agricultural Exteriment Station, Kansas State Agricultural College}

Where grows ?-Where grows it not? If vain our toil, We ought to blame the culture, not the soil.

Pope.

ILLUSTRATED

\section{NEW YORK \\ ORANGE JUDD COMPANY}

LONDON

Kegan Paul, Trench, Trubner \& Co., Limited 
COPYRIGHT, 1907, BY ORANGE JUDD COMPANY

All Rights Reserved

IENTERRd AT STATIONERS' haLL, LONDON, ENGLANת? 


\section{1 \\ Bals}

\section{ACKNOWLEDGMENTS}

The author is under obligations to many friends for helpful suggestions and illustrations. Especial credit is due the following for illustrations used on the pages indicated: Professor E. O. Fippin, of Cornell University, 29. 31, 34, 36, 65, 91, 94, I13, 173, I74, I92, I95. 198, 204, 218, 230́, 266, 280, 283, etc.; Professor A. M. Ten Eyck, of the Kansas Experiment Station, 2, 13, 20, 47, 197, 270; Professor Oscar Erf, of Kansas Experiment Station, 207, 209, 211, 259; Professor Charles E. Thorne. Director of the Ohio Experiment Station, 100, 105: Dr. C. G. Hopkins, of the Illinois Experiment Station, 267, 268; Mr. George K. Helder, 177. 178, I80, 182, 183, I94, 202. Thanks are also due the Orange Judd Company for many photographs and Mr. B. F. Williamson for the line drawings. 


\section{CONTENTS}

Introduction . . . . . . . . . . . . I

I. The Soil Makers . . . . . . . . . . 7

II. The Soils that Living Things Have Made . . . I7

III. What We Find in Soils . . . . . . . 23

IV. Concerning the Texture of the Soil . . . . 34

V. How Plants Feed . . . . . . . . . 44

VI. The Elements that Plants Use . . . . 52

VII. How Plant Food is Preserved . . . . . . 62

VIII. Getting Acquainted with Plant Food . . . . . 7r

IX. The Potential Plant Food: Its Stores and Nature 79

X. The Rôle that Tillage Plays . . . . . . 88

XI. Liming the Land: A Corrective for Acidity . 90

XII. The Quest of Nitrogen . . . . . . . . 108

XIII. The Release of Soil Nitrogen: The Return to the Air II7

XIV. Nitrification: Nitrogen Made Ready for Plants • I 124

XV. Reclaiming Lost Nitrogen : the Call to the Air . . 132

XVI. Soil Inoculation: How Done . . . . . . 143

XVII. Draining the Land . . . . . . . . 152

XVIII. Soil Water: How it is Lost; how it May be Held I64

XIX. Dry Farming: A Problem in Water Conservation 176

XX. Tillage Tools: What They are for; how to Use Them 185

XXI. The Cultivation of Crops: The Tools and Purposes 197

XXII. Stable Manure: Its Composition and its Preservation 206

XXIII. Handling Manure on the Farm . . . . . 216

XXIV. Buying Plant Food for the Soil . . . . . 227

XXV. Using Chemical Manures Intelligently . . . . 238

XXVI. Mixing Fertilizers at Home . . . . . . 246

XXVII. Dairying: An Example in Soil Building . . . 255

XXVIII. Rotation of Crops . . . . . . . . . . 266

XXIX. The Old, Worn-out Soils: What we May do for Them 282

XXX. Conclusion: A Bit of Philosophy . . . . 29I 


\section{ILLUSTRATIONS}

PAGE

Only the Roots Remain Behind . . . . . . . . 2

A Bit of Earth's Clothing . . . . . . . . . . . . 5

Gradually Changing from Rock to Soil . . . . . . 8

Cover Crop for the Orchard . . . . . . . . . . . 12

A Field of Corn Carried Away by a Raging Flood . . . . I3

Just after a Flood . . . . . . . . . . . . 15

Soil Builders at Work . . . . . . . . . . . I8

Alfalfa Roots Go Deep into the Soil . . . . . . . . 20

A Crop that is Hard on the Soil . . . . . . . . . 24

Section of Soil Showing Air Spaces and Particles . . . . 26

On Two Types of Soil . . . . . . . . . . . . 29

Crop Adaptation . . . . . . . . . . . . . . . 31

A Case of Bad Texture . . . . . . . . . . . . 34

Taking Soil Samples . . . . . . . . . . . . 36

The Pore-space of the Soil . . . . . . . . . . 37

A Soil that Needs Hunıss . . . . . . . . . . . . 39

Circulation of Water in the Soil . . . . . . . . 40

Vegetable Matter Aids the Soil in Holding Water . . . . 42

Trees in the Prairic Region. . . . . . . . . . . 43

How Plant Food Gets into the Soil . . .. . . . . . . 44

The Underside of a Leaf with a Microscope . . . . . . 46

Oats . . . . . . . . . . . . . . . . . 47

Cross-section of Root Hair . . . . . . . . . . 48

Root Hairs . . . . . . . . . . . . . . . . . 48

How the Sap Current Moves . . . . . . . . . . 49

The Greater Part of this WVonderful Crop Comes from the Air 55

Getting Humus into the Soil . . . . . . . . . . . 59

Cotton Plant Above and Below the Ground . . . . . . 62

A Root Hair with Soil Attached . . . . . . . . . . 64

Making Plant Food Available . . . . . . . . . . . 65

At Work in the Corn-field . . . . . . . . . . . 67

Cetting Ready for Cotton. . . . . . . . . . . . 68

Puor Grass, Poor Cattle • • . . . . . . . . . 73 
Corn Growing in Surface and Subsoil . . . . . . 76 A Crop that Calls for Much Nitrogen . . . . . . 79

A Crop that Gets Nitrogen froln the Air . . . . . . 82

A Sure Way to Improve the Soil . . . . . . . 84

Increasing the Nitrogen with Legumes . . . . . . 86

Alfalfa Roots: Vegetabie Tillage Tools . . . . . . 89

A Good Job of Plowing . . . . . . . . . . . 91

Plowed for the First Time . . . . . . . . . . 93

Effect of Plowing Wet Land. . . . . . . . . . 94

Limed and Unlimed Land . . . . . . . . . . . 100

Using the Lime Spreader . . . . . . . . . . . I05

A Magnificent Crop of Beans . . . . . . . . . . . II3

Two Kinds of Bacteria Found in Decaying Vegetable Matter . I20

Bacteria Usually Found in Decaying Organic Matter . . . I2I

Some Bacteria that Cause the Fermentation of Urine . . . I23

Nitrifying Bacteria . . . . . . . . . . . . . . 127

Losing Nitrogen and Humus . . . . . . . . . I32

Root Tubercle Bacteria . . . . . . . . . . . . I39

Back of Good Tiilage is the Well-bred Farm Horse . . I 42

Some Legume Roots Showing Root Tubercles . . . . . I45

Growing Bacteria in the Laboratory . . . . . . . . . I49

Alfalfa: the Best All-round Crop in Anerica . . . . . . I50

Red Clover Roots . . . . . . . . . . . . . 153

Soil Temperature . . . . . . . . . . . . . . . I55

A Way to Help the Drainage . . . . . . . . . 156

Losing Soils by Heavy Rains . . . . . . . . . . 158

The Result when Water was Secured and Held . . . . . I64

Effect of Cultivation of Corn Crop . . . . . . . . . I65

Cultivation Checks Evaporation . . . . . . . . . . I66

A Home-made Roller . . . . . . . . . . . . . I69

Disking the Ground before Plowing . . . . . . . . I7I

A Stone Mulch . . . . . . . . . . . . . . . 173

A Good Mulch . . . . . . . . . . . . . I74

Kaffir Corn . . . . . . . . . . . . . . . . 177

Corn Planted with Disk Furrow-opener Attached . . . I78

Double Disking the Land . . . . . . . . . . I80

"Out There in Kansas" . . . . . . . . . . . 181

Sub-surface Packing . . . . . . . . . . . . 182

Dry Land Farming . . . . . . . . . . . 183

Ideal Plowing . . . . . . . . . . . . . . I86

Furrow Slices that are too Flat . . . . . . . I86 
Plowing Levees for Rice . . . . . . . . . I88

Everything is Done at One Operation . . . . . . 190

Where Rolling Does Little Good . . . . . . . . 192

The Acme Harrow . . . . . . . . . . . . 194

A Step in Soil Preparation . . . . . . . . . 195

Corn Roots . . . . . . . . . . . . . . . 197

Cultivating the Orchard . . . . . . . . . . 198

The Gentle Art of Cultivation . . . . . . . . 200

Catalpa Tree with One Season's Growth . . . . . . 202

Losing Water from Soil . . . . . . . . 204

The Erf Stabling System . . . . . . . . 207

Losing Fertility . . . . . . . . . . . . . 209

A Covered Barnyard . . . . . . . . . . . . 2II

Letting the Manure Get Away . . . . . . . . 216

A Common Way but Poor Practice . . . . . . . 218

Hauling Manure to the Field . . . . . . . . 220

Manure Spreader at Work . . . . . . . . . $22 \mathrm{I}$

Crimson Clover in the South . . . . . . . . . . . 224

Cow-peas and Fertilizers and a Poor Soil . . . . . . 227

A Case where All Three Elements Are Needed . . . . 228

Our Common Fertilizing Materials . . . . . . . 230

Where Acid Phosphate Pays . . . . . . . . . . . 233

A Muck Soil that Profitably Uses Potassium . . . . 236

Plant Food in a Bag of Fertilizer . . . . . . . $24 \mathrm{I}$

The Bag and the Plant Food in It . . . . . . . . 243

Fertilizers Pay Best when Good Plowing Has Been Done . . 247

The Soil that Tells Its Own Story . . . . . . . . $25 \mathrm{I}$

Where Alfalfa Prospers Dairying Prospers . . . . . 256

Complete Irrigating System with Dairy House and Residence

Attached . . . . . . . . . . . . . 259

A Balance Wheel in Farming . . . . . . . . 260

Two Kinds of Farming . . . . . . . . . . . . 262

Relative Amounts of Plant Food when a Ton of Each is Sold 263

Crop Rotation . . . . . . . . . . . . . . 266

Corn in Growing Stage . . . . . . . . . 267

Corn at Harvest Time . . . . . . . . . . . 268

Cow-pea Roots . . . . . . . . . . . . . 270

Crop of Corn and Cow-peas the Same Year . . . . 272

Close Rotation of Crops . . . . . . . . . . . . 278

Crop Rotation and Mixed Farming Go Hand in Hand . . 277

Timothy May Go in Rotation . . . . . . . . . 280 
In Perfect Condition . . . . . . . . . . 283 What Humus Does in the Soil . . . . . . 285 Grow Legumes Constantly . • • • • • • • . 288 One Kind of Farming that Improves the Land . . . . 29I A Sure Way to Ruin the Farm . . . . . . . . . 293 Seven of Our Leading Products . . . . . . . . 295 Intensive Farming . . . . . . . . . . . . . 296 A Department of the Farm Factory . . . . . . . 298 "Thro' Wood and Mead" . . . . . . . . . . 299 



\title{
THE PLOW
}

\author{
By V. I. Boyson
}

[By courtesy Everybody's Magazine.]

I am a worker.

Sleep on and take your rest

Though my sharp coulter shows white in the dawn:

Beating through wind and rain,

Furrowing hill and plain

Till twilight dims the west

And I stand darkly against the night sky.

I am a worker, I, the plow.

I feed the peoples.

Eagerly wait on me

High-born and low-born, pale children of want:

Kingdoms may rise and wane,

War claim her tithe of slain,

Hands are outstretched to me.

Master of men am I, seeming a slave,

I feed the peoples, I, the plow.

I prove God's word true-

Toiling that earth may give

Fruit men shall gather with songs in the sun.

Where sleeps the hidden grain

Corn-fields shall wave again;

Showing that while men live

Nor seed nor harvest time ever will cease.

I prove God's words true, I, the plow. 


\section{INTRODUCTION}

\section{THE EARTH'S CLOTHING}

It has been calculated that if the earth were tunneled direct to the other side, 7,91 8 miles would be traveled in making the journey. But a difficulty would be met in this endeavor: After going a few miles, the heat would be so intense that further progress would be impossible. For as we descend into the earth, after going a very little way, the temperature rises at the rate of I degree for every 50 feet, a rate that is universal over the earth's surface, and for the greatest depth attained.

From the known laws of the conduction of heat the conclusion follows that at a depth of 15 to 20 miles below the surface the earth is red hot, while the heat roo miles deeper, if applied at the surface, would liquefy all materials at the surface crust. These known facts have led to an hypothesis that the interior of the earth is more or less fluid, and that the crust is only a thin shell floating on the molten globe.

However, the earth as a body is very rigid and subjected to a pressure so great that despite the high temperature, the interior is locked into a solid mass as rigid as steel itself.

But after all, we are concerned less with the interior of the earth and with the surface more. Our aim is to know the outer covering-the clothing that encloses this hidden interior-and to use its history to our profit and grood. Every science has labored with the secret that is hidden in this clothing of the earth that the world might know some of the stories it has to tell: of the 
strange forms of vegetation that once visited here; of the bizarre creatures that peopled it in old days-before man came and before the myriads of present-day friends and foes had sprung into existence; of the monsters that throve and multiplied and brought fear and death to weaker kind; of the hideous reptiles that crawled over the slimy domain, battling with each other or with the

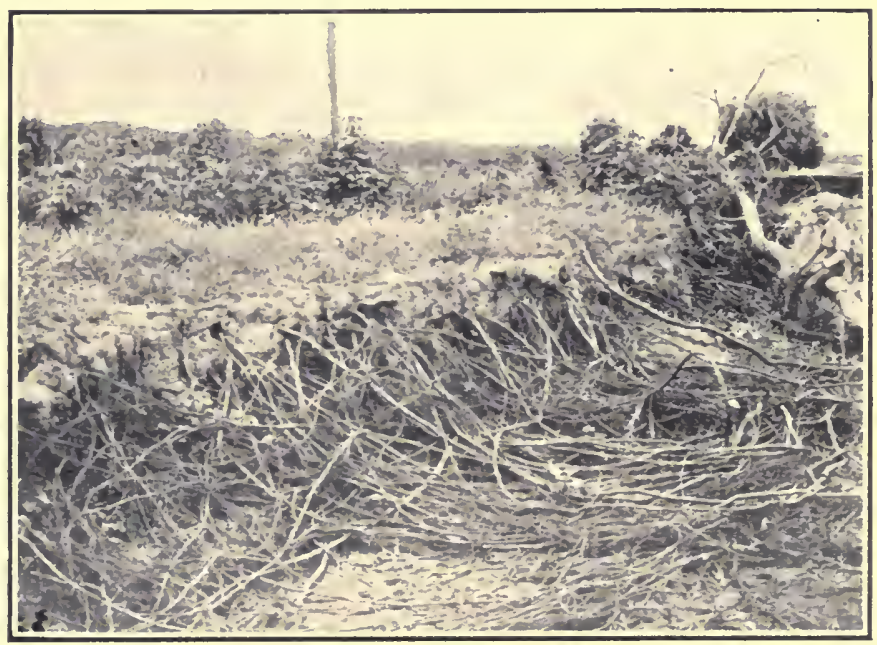

ONLY THE ROOTS REMAIN BEHIND

This picture is an example of the power of water in soil making

denizens of the forest; of primitive man-weak, dull, savage, and yet endowed with more cunning of brainfulfilling his mission and preparing the way for better and higher tribes; of all the agencies that have been at work in the making of the garment that covers this great body; of the soil, the real covering, and all it means: these many stories have been told in rock and stone and 
in slowly perishable materials, and so clearly told that man reads and reflects and profits in the lessons that are learned. And of some of these we want to learn in the pages that follow.

The soil: the clothing of the earth.-The real clothing of the earth is the soil-and we are to study it: the good, kind soil that brings us so many useful and beautiful and wholesome things. For with the soil is the real beginning of all material things, of all useful things; of all things that secure contentment: of all things that lead to comfort and happiness; of all things that have to do with food and raiment and shelter; of all things that advance mankind and promote civilization. All of these things spring from the soil-from the simple, inanimate, material thing we call dirt.

The earth's clothing includes the soil in all its variations; includes the dirt in which plants root and feed and grow; includes the rock and stony structures of sea and mountain; includes the waters of the soil and of the deep; inclucles the minerais in the mines that man secks. often losing his life in the search; includes the insect. the worm, the bacteriun, and every form of life that labors for its usefulness and grancleur; includes the fruits of field and soil-the life that grows therein and makes food for man and beast; includes the tree that grows and fructifies in forest or orcliard; includes the cultivated crop of every variety and species, of every form and description; includes every vegetable type that provirles raiment, or covering in the open, or when removed from its place of growth. becomes house and shelter that protects and guards and comforts: includes everything that has use and that supplies a want in every part of the world and for every purpuse. All these things come from the soil, from the magnificent garment 
that clothes the earth. "Before literature existed, before governments were known, agriculture was the calling of man. And all the fruits of social progress since then grew from the brown soil."

The soil changes its clothing.-The clothing of the earth is a changing one. It is of as many colors as the coat of Joseph. And this clothing changes not in color only, but in texture, in wearing ability, in usefulness. For are there not many soils that had poverty as their inheritance and still others that had only the fullest riches? Yet both kinds meet at a common point so often-the rich have become poor, the poor have become rich.

All over our land this change is observed. To man's credit, however, we are now at a point in farming where this may be corrected, for we realize that the soil is capable of change and of improvement: it offers a great opportunity for thought and study. Applied here, knowledge brings abundant returns.

The soil and the subsoil.-There are two layers of this clothing: the soil and the subsoil, and of course we must give due weight to both with any discussion of crop production or in any method of land management. In both soil and subsoil are found organic and inorganic materials, although the subsoil contains a greater portion of the latter substances than the soil immediately over it.

It is in both of these layers that the roots of plants grow, and now that we know more about roots than we did a few years ago, we ought to be able to handle lands with greater certainty and to grow crops with more profit. We know where roots grow; we know the places in which they feed and just how they do their work. Is this not a practical turn? Roots grow from their tips, and at these points they gather food and drink. With the passing of 
a little time the tip end is sent further on in the search; it grows longer; it finds a new place to take nourishment.

The roots grow on and on and new root hairs form, taking their nutriment from the new and fresh pastures. So all about in the soil they go, just below the surface, a little deeper in the soil top; even in the subsoil (if they can enter it), and all the while they search and seek for plant food that the great borly above may be supplied.

Fertility is more than soil.-And we should bear in mind that fertility is more than a mere abundance of plant food in the soil (we have learned more about the soil). Fertility is plant food, of course, but in part, only. It is water-just the right amount and served when needed. It is climate-neither too cold nor too hot for the particular plant. It is texture-soil grains of proper size and in proper relation to control heat, moisture, and air. It is humus-a goodly amount to supply nitrogen as required, and to help in making pleasant and comfortable the home of the roots. It is tiilage-the real, true sort of tillage that provides tilth and mellowness. It is

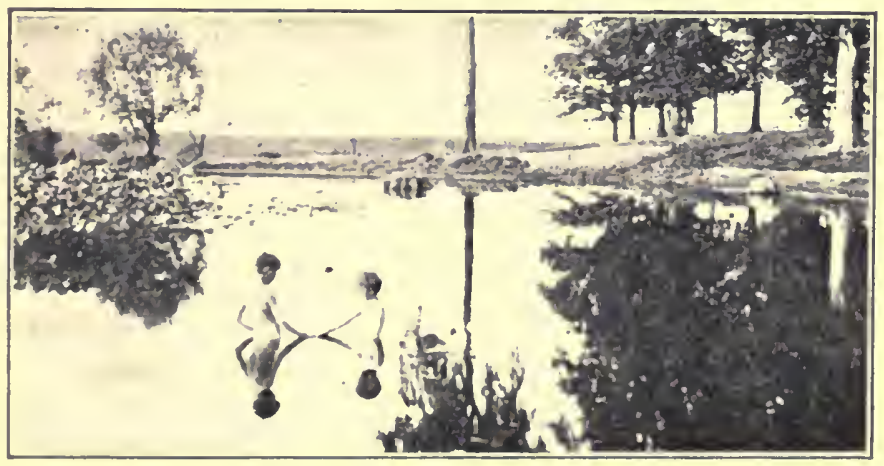

A BIT OF THE EARTH'S CLOTHING 
the plant-the riglit kind for the particular soil. Fertility springs from these and from all other contributions that secure a soil environment to the liking of the growing plant. Hence, the plant food of the soil is an incident, but a necessary incident, just as heat and air and water and tillage and texture are incidents and prerequisites of high production. 


\section{SOILS}

\section{CHAPTER I}

\section{THE SOIL MAKERS}

Do not think, gentle reader, that I am going to weary you with a long discussion about the history of the ground. The only misgivings the author has had in the preparation of this volume has been the necessity of saying these few words that follow about the soil makers, the agencies that have been at work making the soil. Important? Yes, in a way; but if you see the matter as I do, you are more interested in having the soil demonstrate what it can do now, rather than to inquire into its line of descent ; to be familiar with its ability to do work and to perform to-day, rather than to know its ancestral life of long years ago.

First effort in soil making.-To find the first effort in soil making we shall have to go back to a time far into the past; back before man had appeared; farther back yet than the time when plants had begun their existence. For is it not true that plants must have raiment for their roots-earth in which they may grow and out of which they may get food and drink?

We shall have to go back-very far back in the pastwhen the surface was coling and forming its crust, when the entire surface of the earth was rock-no animals, no cultivated crops, no trees, no grass-not even the tiniest form of lug or plant or beast.

For at this time the earth was void and without form, 
although surrounded by an atmosphere of mist and vapor. When this rocky and molten mass of earth began to cool, its crust became broken and uneven. But no soil was there, only hard, fire-burned rock. Then centuries passed-thousands and thousands of them. The molten mass had cooled. The darkness that was on the face of the deep gave way to light and change. For the light came from the sun and these rays the rocks absorbed. They felt the refining influence, also, of the air as it played over the wrinkled faces of rock and cliff. At first these two agencies made but little, if any, impression. So hard was the rock, what might air and sunshine do?

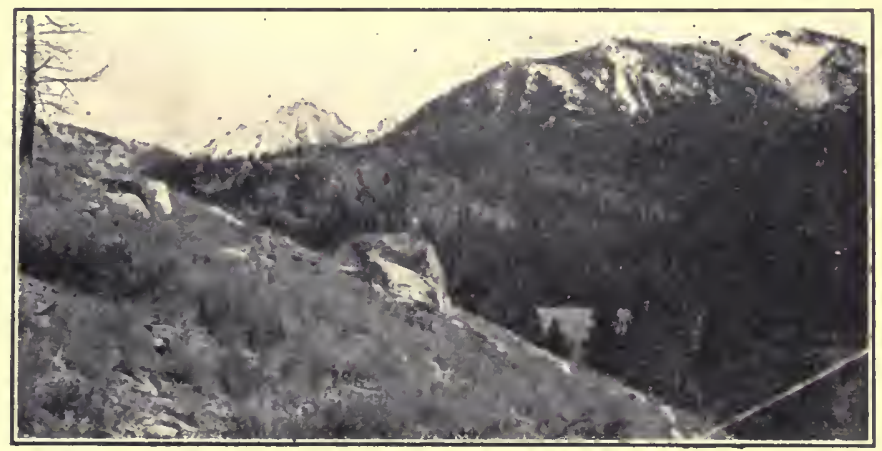

GRADUALLY CHANGING FROM ROCK TO SOIL

But busy bodies, that are at work always and ever, gradually gain their ends, and so these first rocks, now cold, now warm but yet so hard and strong-and so brutalslowly gave up their determined tenacity and lost some of their strength and hidden power. A little softening, and they were changed, just as the refining influence of good air and much sunshine refines the plant or beast or man that comes under their spell and change. 
How the atmosphere assists.-Just as soon as the first rocks were exposed to the weather, remarkable changes then resulted. The rocks, after long exposure, crumbled somewhat; just a few particles, a few tiny grains from time to time fell apart from the whole and dropped to a lower level to be carried away by water; or they were picked up and carried away by the wind when it rose in sufficient force to defy the miglity giants of rock formation. Of course the wind accomplished but little with each attack. But the wind is ever young; it never grows old, and a thousand years of trial weaken it not. These tiny particles-the first released from rock-represent the beginnings in soil making. And ever since the time, who shall say how long? that these first particles were given to the wind, the weather has been at work making soil.

The atmosphere assists in soil making because of the chemical action of the gases that compose the air and of the moisture or vapor it holds. The two important gases that are so powerful in making soil are oxygen and carbonic acid. They are always at work; they have been at work from the very beginning of time; and so long as life exists, from the tiniest plant up to the finest developed type of man, oxygen will be required for the work of the world.

Oxygen forms oxides by combining with nearly all sorts of materials that are found in the earth. You know how quickly iron rusts when exposed to the air, especially if moist-an oxide of iron has resulted: not that the iron has been destroyed nor the oxygen of the air that combined with it, but the two lave united and formed a new chemical compound, powdery in texture and now in a form to be easily combined with acid so as to become food which plants may use. 
The carbonic acid of the air serves its part, also, but in another way. It works with water and in this manner: the two substances-carbonic acid and water-readily commingle and produce a liquid that is strong as a solvent, effective as a dissolving agent, so as to weaken the rocks, and active as a selective power which seeks the soft minerals of earthy formations and quarries them for plant builders to use.

Oxygen and carbonic acid work whether man would have them or not; they ask not his permit when they shall work nor where; and neither do they ask on what materials they shall satisfy their desires. They work for Nature and to her they belong, and in this case they refuse to bow or to conform to man's wishes.

But air and water are usually most effective as soil makers when they are working together, for they accomplish more and do it more quickly. You have seen perhaps some iron tool that for years has remained in the bottom of a well, the water having made no perceptible headway against it. Because no air was there, rust did not result. And again, you have seen another iron tool kept in an atmosphere that was dry. You note no perceptible disintegration because moisture is highly essential for iron to change into its own powdery dust.

In dry climates rocks last longer than in moist climates for the reasons explained in reference to the dissolving action of air, carbonic acid, and moisture.

Changes in temperature play a part.-In the early days the earth had a larger garment to clothe it than it now possesses. It was very hot-a boiling mass, at first. As time went on, the outer crust became cool, and at the same time this crust hardened and became fixed in character, but only temporarily; only long enough for the cooled crust to deepen its thickness, when the entire body 
must contract; because, you know all matter expands when heated and becomes smaller when cooled. With the cooling of the earth its outer clothing was drawn in. with the result that it was wrinkled-hills here and high mountains there-which continued so long as the contractive force was greater than the holding force of the crust. In all this work changes were taking place. Huge beds of rock were thrown up and exposed in an hundred places to air and moisture, where before they were so snugly covered that neither could enter.

The earth continued to cool and in some places ice formed. Vapor condensed and dropped as rain. For centuries rain had fallen, but as it struck the hard earth it was flung back into the air again as vapor and mist. As the earth gradually cooled, water was thrown back with less vengeance and force. Some of it was left for a considerable time on the earth, where it had collected in basins, or in crevices in the rock. It was caught here at times by wind-storms that were cold enough to freeze this gathered water. As the water froze, it expanded, forcing many crevices wider, breaking many rocks asunder-and doing what we are pleased to call its share in soil making.

It is this change in temperature that assists in soil making-that weakens the original rocks that were ages ago forced from the very bowels of the earth.

Rocks such as the granitetype-whenalternately heated and cooled for a long time-gradually weaken and break. Surlden changes in temperature produce similar results. Temperature is more active when moisture is present. Fven in the modern world we see stone buildings, that frequently (lrop a corner or a slab, due to suclien freezing when saturaterl with water. You recall with what ease the same may be lone with a hammer on a cold day.

Since nearly all rocks, even those deeply imbeded in 
the soil, contain not a small amount of water, cold becomes a most potent as well as a most active agent in breaking and pulverizing them and in preparing them for the soil itself.

Water wears away the rock.-But water is a soil maker in another way than as a solvent. By simple friction it wears the hardest rock and makes for itself a track in which it may flow with greater ease. This action of the water has been so constant, and so regular, through so many summers and winters, and at work for so many, many centuries, that it has widened and deepened its

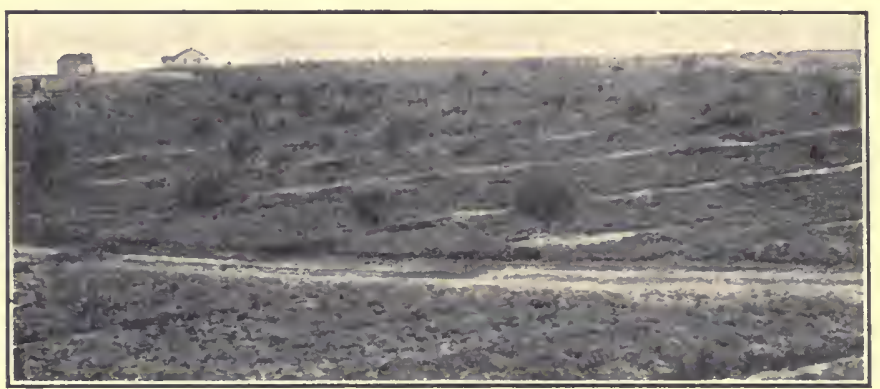

COVER CROP FOR THE ORCHARD

Oats are used here, and dogood service for protection against water and wind

channels in all parts of the earth so that millions and millions of tons of solid rock have been washed from higher to lower levels, the dissolved part being left in lower regions or carried out into the sea, where the accumulations for centuries have made new lands, some of which are now and for long times have been used for the growing of many of the necessities of man.

Every time you see moving water in a stream, you see a soil maker at work. With even a light shower the water deepens its color, since the stream, the road and the field 
give up their finest dust, and send real soil downward to a lower level. It is beyond our power to estimate the enormous quantity of soil that is moved during a single year. A single illustration will show how great this quantıty is: The Mississippi River as it pours into the Gulf of Mexico each year deposits soil sufficient in quantity to cover an area of 100 square miles nearly three feet in depth. Add to this the outpourings of all river systems and you have land areas made each year that equal many a state in size. Whenever a river outflows its banks it leaves deposited on the submerged territory tons and tons of mud-and this mud is valuable soil-often as much as an inch in thickness.

In all mountainous regions we have the results of the wearing power of water. Huge cañons, hundreds of feet deep-the Colorado Cañon is 6,000 feet in depth-mark the track of the leaps and pourings of water from the mountain summits. When considered in the aggregate, the amount of soil made by water-washing of our thou-

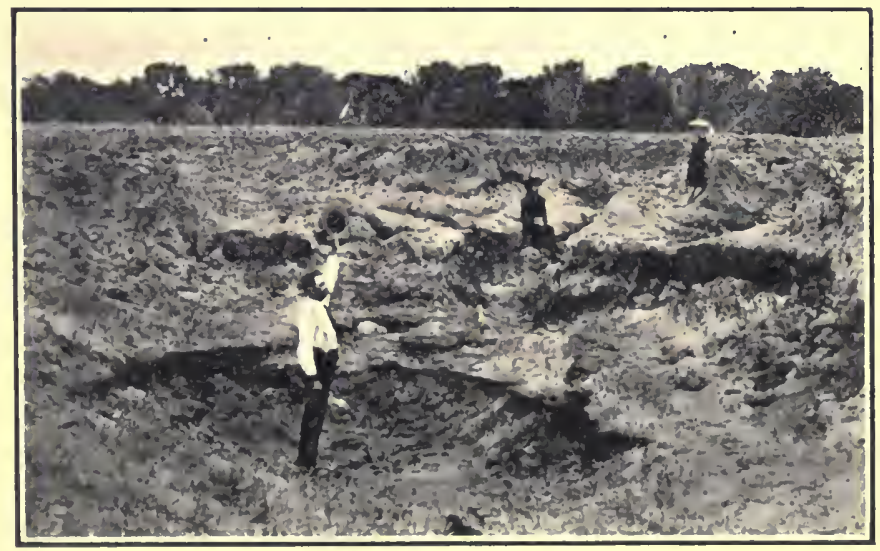

A FIELD OF CORN CARRIED AWAY BY A RAGING FLOOD 
sands of hills and mountains is large. Here we see a mighty force and a powerful agent at work in soil making.

The sorting power of water.-In this connection we should not forget the work of water as it moves silt, clay, pebbles, and stone that have been caught in its channels and then moved downward toward its emptyings. Silt and clay are readily held in suspension even if the water is slow going. It requires rapid currents to move the heavier, coarser stoncs and pebbles. As these are carrich along, their rough edges are worn off, their sides are scraped and scratcherl, and many particles are pulverized and ground-all contributing to soil making. To be sure, this soil will be fleposited in lower regions, yet it is now soil. the same as that in the cultivated field or garden.

The rôle that ice has played.-In the northern part of the United States we have a class of soils formed by giant masses of ice called glaciers, that moved in a southward course many, many centuries ago. Our ideas of the cause of this vast body of moving ice are not clear and we have only the evidence that once it was so. We are told that all the northern part of our country was covered with a frozen mass of ice and snow, and that for some reason this whole mass assumed a moving character, creeping over plain and stream, attacking every hill top and mountain range, and without further ado, conquering them as if play mounds made by children's hands were the confronting power.

As this huge mass moved onward in its course it gathered up huge rocks that once were free, quarried other giants from the bosoms of the mountains, and played with them as it went along-rolling them, forcing them together, dragging them, rubbing their rough faces until they were smooth (if perchance they were not completely ground into powder) - until finally the rays of the 
more southern sun robbed the glacier of its power by melting snow and ice, which freed, rushed on into river channels to be lost at last in the seas of the East and the South.

Soils that were formed by this moving mass of ice are known as drift soils. Such soils vary greatly in composition and in physical nature. The area formed by these glacier or drift soils is altogether lacking in uniformity. its surface is broken often abrupt, its elevation is sometimes considerable, often but slight and its producing power is modified by the nature of the deposits. While it is true that these soils are fairly well supplied with necessary mineral constituents essential to plant growth

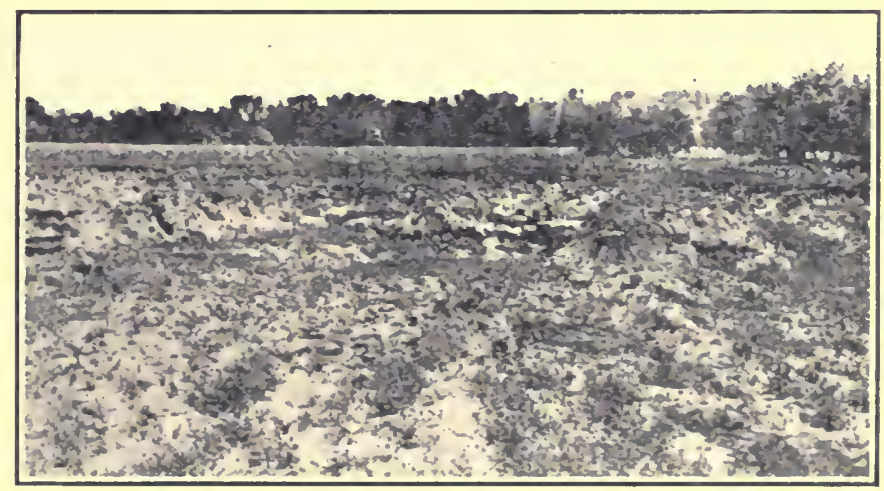

JUST AFTER A FLOOD

they are often deficient in organic matter-the source of nitrogren supply.

Wind made soils. - Il hile the wiml is often most vigorous in its activity, it is a reasumably slow agent in soil making. when comsinered hy its latily work: it must he

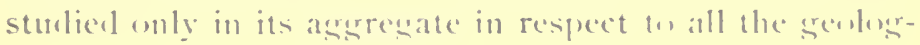


ical ages past. You will find the wind most actively at work in arid regions and in those sections where sand and dust most abound.

A single experience in a wind storm must convince you of the power as well as of the quantity of earth that is moved throughout the world. Dust or particles of the earth are in the air at all times, and with every drop of rain, every flake of snow, and every movement in the air these particles are carried elsewhere than to the spot at which they were originally gathered up. You will find in some sections of our country huge mounds or drifts of sand that have been deposited by the constant and more vigorous action of the wind. 


\section{CHAPTER II}

\section{THE SOILS THAT LIVING THINGS HAVE MADE}

No one knows just when the first plant came into the world, nor the kind: it was too far back in the dim ages of the past; long before any history was ever written; long even before man or bird or beast had yet appeared. We may be sure, however, that it was a very tiny plant, so small that the little roots did not need to go deep into the earth, for the soil was just beginning its growth. We may be safe even in saying that these early forms of plants had only the rock itself for their homes, and on this rock they established themselves, sending their small roots just the tiniest bit into the crevices and into the opened particles that had been loosed by air and water, by heat and cold.

The beginning of plant growth.-But doubtless the earliest forms of plant life were aquatic in character: they lived in the water. We have learned of the solvent power of water. Many of the early stagnant pools became depositories of water holding in solution the dissolved mineral materials of the kind forming the rock structures. 'This was just the sort of food that these pioneer plants fancied, for they and all of their kind since have secured their feeding materials in this manner. As years and centuries passed, these beginning forms of plant life became stronger, more steady and some became quite venturesome, clinging to the rocks that held fast the waters of the pool; and still others, flinging the experience of their parental tribes to the winds, ascended beyond the limits 
of the pond, where flowing water was uncommon, there to become adjusted to their new homes and to their new environment-at last to be stationary in their rules of living.

It is likely the first stationary forms found lodgment in the crevices of the rock, where perhaps had accumulated small quantities of soil that had been made long before by air and water working in unison. These plants, no doubt, set their fibrous roots firmly against the rock surfaces and worked in their own way in securing the coveted elements locked in the storehouse of the rocks.

Just as the ivy of to-day creeps over stone and brick, so did these first forms secure their food substances for their life and growth. But with this difference: those were small, insignificant plants and of low order; the ivy has culture, good breeding and pedigree as its inheritance.

Real soil was made and left.-You must not think

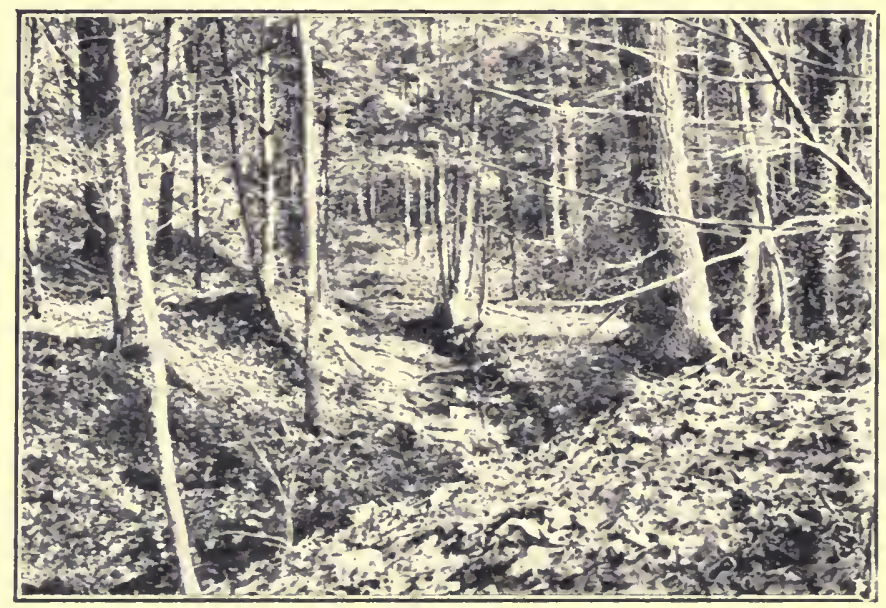

SOIL BUILDERS AT WORK

Leaves, roots stems and grass find their way back to the soil and enrich it 
these pioneer plants lived forever. They grew old in time: they died. But at their death they left a valuable contribution to the world. They left the riches they had accumulated: the elements they had secured from the rocks, the substances of their growth, the wee beds of soil they had secured from their forefathers, from the donations of the wind, and from the gifts of air and moisture.

With this wealth available, there was no longer so great a struggle. The decayed plant life in the crevices and the deteriorated rock afforded better feeding grounds for plants, more soil for support, more food for the needs of maintenance and of growth. Consequently, this bettering of material necessities afforded increased opportunities for growth. A higher order of plants might now come. So the small struggling plants, through a long course of years, changed, now gradually, now suddenly, into stronger varieties and species-onward and upward in the scale, until the time when soil was present in abundance, when the higher plants, useful for food and raiment, might be secure and safe, thoroughly fitted and abundantly adapted to all the environmental conditions needed for their complete development and growth.

The work of plants in soil building.-It follows, then, that every kind of plant is a soil builder. The decay of the plant at once produces a change in the texture of the soil-making material. It is this adclition of the organic matter-the dead plant-that produces this constantly performed miracle: for as the plant decays in the soil, the particles of soil in contact with it likewise decay. In other words, soil rotting is soil making. Decay of any material in the soil-organic or not-favors and induces the breaking down of the various complex compounds forming the rock, or the raw or the untaned soils. 
The addition of vegetable matter to the soil has assisted in soil making from the time that plants came first to the planet; it has increased the efficiency of all other agencies ever since the early days; and at the very present time it is the soil builder's best friend,-its decay is essential to the feeding of plants.

The roots of plants have done their work in soil making. A great work it has been! For they have gone down deep into the soil making tiny channels for air and water; creeping into the crevices of rocks, they have continued their growth and their enlargement, in the end, breaking

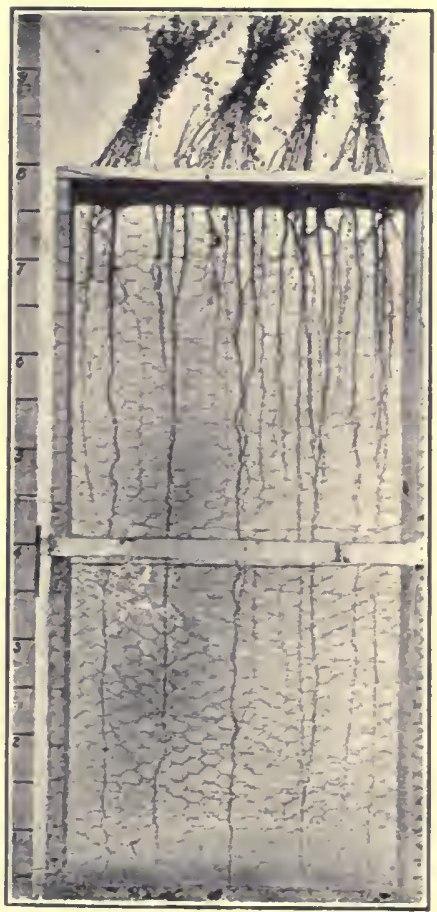

ALFAJFA ROOTS GO DEEF INTO THF SOII. many rocks asunder, dislodging others from their beds,--exposing all to the disintegrating influences of air and moisture, of heat and cold.

And roots - especially the small, fibrous oneshave a solvent action as well. The juice they exude at the tips, and the moisture with which they s u r round themselves, work a change in the soil particles between which they grow; limestone or granite or feldspar or mica slowly but surely suc. cumbs to the deteriorating action of root life.

Animals the modern soil makers.-Soil making was considerably 
advanced when animals first made their appearance. But animals of all sorts have been potent workers in soil making, the higher animals largely by the manurial return to the land and the lower forms through the manurial effect, but also in directly affecting the physical conformation of earth.

For does not the ant seek the earth for its home and shelter, to construct there its house of many rooms, with the many tunnels connecting the dwellings of the nation? What are these homes and these tunnels but underground traps for air and moisture-soil builders?

Besides the work done in this direction, a tremendous quantity of earth is annually turned over and exposed to sunshine and rain, to heat and cold, to every influence concerned with soil making and soil improvement.

Every sort of insect or animal that burrows into the soil, that opens it, or tunnels it, or loosens it, contributes not a little to soil making: the ant that builds there, the mole that tunnels, the prairie $\log$ or hedgelog that burrows, the earthworm that glicles and crawis. and even eats and digests-all are man's good friends in having had a hand in preparing the surface of the earth for th: luxuriant growth of vegretable life.

The task of the earthworm.-The task that has been the earthworm's is a most important one. So simple are these creatures, so faithful are they in their labors, so undemonstrative in their duties, we scarcely give them a thought save the time when we seek them for bait for our fishing traps. Pint the earthworm has for ages been busy opening the soil to air and water, and even more: it eats the raw soil underyround and plows its way upwards and downwards, casting at the surface the unused portions of its eatings. In loing this, the muscular gizzard of the worm is ever busy rubbing and grinding stony 
particles, mixing with these the organic matter taken into the body system; with these go the secreted slime that has a dissolving effect-useful in making subsoil and untamed earthy constituents available as food for plants.

As proof of the great good of these indefatigable workers, we have the evidence of Charles Darwin, who after long study and observation declared that in many parts of England as much as ten tons a day of dry earth annually were passed through the bodies of these common worms of the field. He also calculated that as much as ten inches of the upper surface of the soil passed through their bodies every fifty years. You can gather from this evidence what worthy workers these insignificant animals have been in preparing the earth for the habitation of man. The increased production of all products of the garden, of the orchard, and of the field has been due, in not a small measure, to these underground helpers and to these wonderful workers in soil making. 


\section{CHAPTER III \\ WHAT WE FIND IN SOILS}

Having come now to the point where soils are made, we may with all propriety consider their physical nature, and then the treasures they hold fast secured in their earthy storehouses. Not that soil making has ended, for this process goes on forever. Only this: a time has been reached in their development when, with the aid of tillage tools, the most productive and useful of plants might now be grown for the highest profit of man.

Let us go out into the field itself. Of what is this soil made? was at one time the first inquiry. Naturally, it was said that soils were derived from the original rock formations. We have discussed already the agencies that have made our soils. No single one is responsible for yours or mine. That we possess these soils, there is no doubt. What brought them to us, what placed particular soils within the limits of our possessions, what influence or agency made them rough or level, good producing or poor producing, is not the problem now.

Four kinds of soil materials.-Our present inquiry is in reference to their physical conformation, to their component parts, to the minerals composing them. These materials are: sand, silt, clay, and humus or organic matter. All productive soils contain these materials, but not in the same proportions. There is a wide difference in the quantities of each in our many varieties of soil. A preponderance of one of these materials over the normal 
average gives rise to a grade distinguished by the name of the material there present in excess of that normal average. Hence, we get names that stand for the particular type, as sand soils, where much sand is present; clay soils, where much clay or silt is present; and humus soils, where much organic matter is present.

Plants show preference for certain soils.-And there is a very great problem unfolded here, for the most of our field crops do not do equally well on each of these soil types. Not a little partiality is shown. While some crops are not so very choice of their soil homes, others are par-

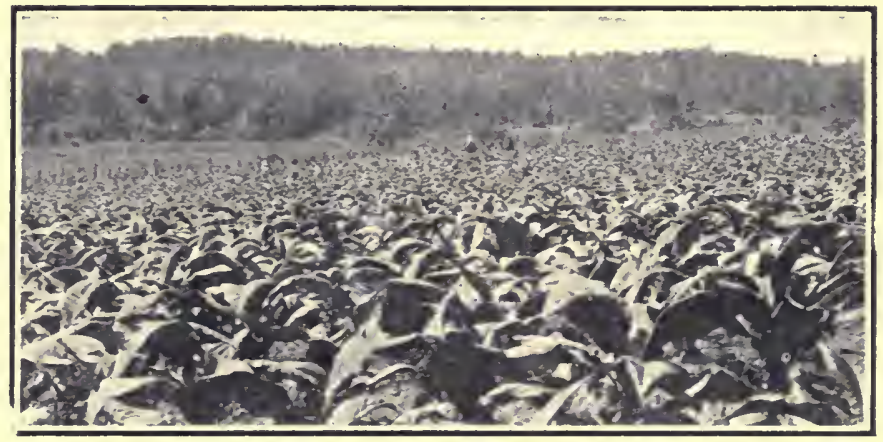

A CROP THAT IS HARD ON THE SOIL

Tobacco is usually a profitable crop, but one that quickly exhausts the soil of its fertility

ticularly mindful; in fact, some. like the grape or tobacco plant, permit their fancy to extend even as far as the manufactured product.

Size of soil particles.-It is due to the size of the particles of which soils are made that we have our various classes of sand and silt and clay-rock descendants. When these particles are separated mechanically, we find 
that they can be classified into various groups, as follows: fine gravel, coarse sand, medium sand, fine sand, very fine sand, silt, fine silt and clay. To these components let us add humus, moisture, the soluble plant food elements, and we shall have the soils of our fields.

The size of these particles and their mechanical arrangement have much to do in way of influencing soil productivity, of influencing heat, moisture, and plant food factors, of governing the type of soil that each crop fancies. Thus it is that a sand soil-where the coarser particles predominate-is a most favorable medium when reenforced with humus, in which certain crops, like the vegetables, are most at home. On the other hand, you will find the opposite extreme-where the finest soil grains predominate-most favorable to wheat and grass. In the first case-the sand type-water is freely received and as freely given to the subsoil, while with the clay type water enters with difficulty but remains longer with its host. Between these extremes we find all sorts of modified types: light sand loams, sand loams, loams, clay loams, and heavy clay loams. IVe should adcl, also, humus to these combinations, for it must be understood that humus is positively a necessity for remunerative crops, regardless of type or of ancestry.

What mechanical analysis shows.-To illustrate this point, let us take the mechanical analysis of barren sand soils: examples of the sand type that are found in many sections of the country-along the seashore, in the sand hills of the arid West, and throughout the desert regions.

Using the plan now gencrally approved by soil investigators, we get the following-the average of I barren sand soils: 


\section{BARREN SAND SOILS}

Material

Per cent

Organic Matter.......................... $\quad 3.75$

Fine Gravel, 2-I mm..................... $\quad 1.40$

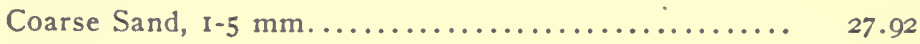

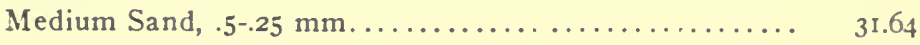

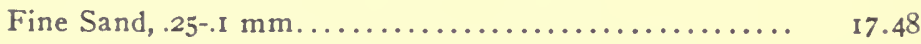

Very Fine Sand, .I $.05 \mathrm{~mm} \ldots \ldots \ldots \ldots \ldots \ldots \ldots \ldots \ldots . \ldots \ldots$

Silt, .05-.01 mm.......................... 1.90

Fine Silt, $.01-.005 \mathrm{~mm} \ldots \ldots \ldots \ldots \ldots \ldots \ldots \ldots \ldots \ldots \ldots . \ldots \ldots$

Clay, $.005-.0001 \mathrm{~mm} . \ldots \ldots \ldots \ldots \ldots \ldots \ldots \ldots \ldots \ldots \ldots \ldots \ldots \ldots \ldots$ I.II

The above percentages tell their own story: they show the classes in which these soil particles fall. In other words, as much as 84 percent. of these barren soils is composed of sand. You can note readily the small percentage of silt, humus, and the clay components. Were plant food to be added, it would be lost as quickly as the water that falls as rain.

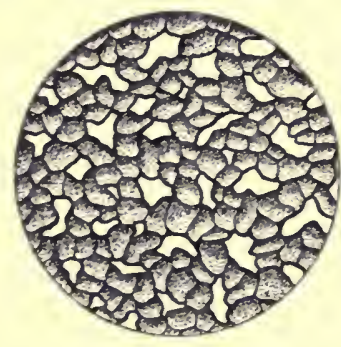

SECTION OF THE SOIL SHOWING AIR SPACES AND PARTICLES

Soils containing so high a percentage of sand may be used for a limited number of crops, and then only when reënforced with organic matter, chemical fertilizers. and water at frequent intervals (by irrigation, if possible).

What special soil types show.To develop this idea further, let us take the analyses of a few soils where certain standard crops grow to their fullest perfection, not for a single year, but for a time of sufficient duration to give these soils the right to the name of model examples of their type or class. 
MECHANICAL ANALYSES* OF TYPICAL AGRICULTURAL SOILS

\begin{tabular}{|c|c|c|c|c|c|c|c|}
\hline Material & Corn & $\begin{array}{l}\text { Wheat } \\
\text { Soil }\end{array}$ & Grass & Truck & $\begin{array}{c}\text { Barren } \\
\text { Clay }\end{array}$ & $\begin{array}{c}\text { Bright } \\
\text { 'lo- } \\
\text { bacco }\end{array}$ & $\begin{array}{c}\text { Heavy } \\
\text { To- } \\
\text { bacco }\end{array}$ \\
\hline Fine Gravel, 2-1 $\mathrm{mm} . .$. & $0 . \infty$ & $0 . \infty$ & $0 . \infty$ & $0 . \infty 0$ & $0 . \infty 0$ & 3.09 & 1.12 \\
\hline Coarse Sand, I-s mm.... & 0.15 & 0.23 & 0.08 & $0.3^{\circ}$ & 0.00 & 7.16 & 1.82 \\
\hline 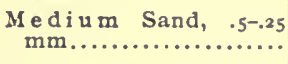 & 2.65 & 1.72 & 0.13 & 6.04 & 0.29 & 21.74 & $1 \cdot 37$ \\
\hline Fine Sand, $.25-.1 \mathrm{~mm} .$. & 16.25 & 6.08 & 0.53 & 49.63 & 1.27 & 22.92 & 0.39 \\
\hline 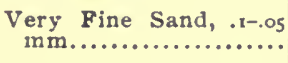 & 26.81 & 36.82 & 10.94 & 32.29 & 8.93 & 16.76 & $4 \cdot 34$ \\
\hline Silt, .05-.01 $\mathrm{mm} \ldots \ldots \ldots$ & 25.30 & 20.92 & 19.02 & 6.24 & 20.16 & 13.17 & 34.40 \\
\hline Fine Silt, .01-.005 $\mathrm{mm}$ & 15.60 & II.2I & 4.67 & 1.93 & 16.72 & 8.24 & 10.58 \\
\hline Clay, ..05-.000r mm..... & 10. xo & 23.78 & 51.75 & 2.80 & 50.02 & 4.80 & 35.24 \\
\hline
\end{tabular}

What does this table show? This-in a most striking way: that wheat soils, handled under certain conditions, possess a moderate quantity of their soil grains in the form of very fine sand, silt, fine silt, and clay; that truck-crop soils possess but a small quantity of the finest grains, their characteristic lying in the great quantity of fine and very fine sand; that the bright tobacco soils possess a limited quantity of the finer grains and most of the coarser grains, while the heavy tobacco soils are largely composed of the finer grains with a much lesser quantity of the coarser materials; that the grass lands possess a very great quantity of clay and silt, but a relatively small amount of the coarser sand grains.

In this table two types of grass lands are shown: the productive and the barren. The former is in good physical condition, that is, its texture is in good form: the soil grains are reasonably well arranged, the humus content

- United States Department of Agriculture. 
(while not given here) is probably sufficient to insure a healthy influence on plant growth. The barren clay here discussed is just as rich in plant food, but the soil grainslargely clay-are so arranged that the soil is puddled; it offers extreme resistance to rain in its passage through, so that when plants are grown in this type of soil they quickly use the water about their roots-and much to their hurt.

Wise farming plans will be in the line of drainage by tiles, thorough aeration by good tillage, and much organic matter supplied through stable manure and the legumes.

How soil type affects plant growth.-The explanation of this is here: soils of a sandy nature maintain less moisture-only 5 to 7 per cent.-than those of a clay nature, and they are more open, the soil grains are larger, and the water resistance small. Hence, they dry out more quickly after rains and become sufficiently warm early in the spring and soon after rains, so that maturity is hastened.

Grass lands, on the other hand, because of the large amount of small grains-silt and clay,-maintain from I 8 to 20 per cent. of water, or nearly four times that of the truck lands. Consequently, these soils are colder by nature and therefore less active in maturing their crops. A longer time is needed, and this is favorable to the heavy leaf growth of grass,-a thing altogether undesirable for vegetable crops.

Wheat lands, since the season of growth is long, are influenced favorably by this same fact of size and arrangement of the grains.

It sometimes happens that seasons are extremely favorable-sufficient water, warm weather in early fall and spring, and good covering of snow for winter protectionand wheat on the very stiff lands does moderately well, 

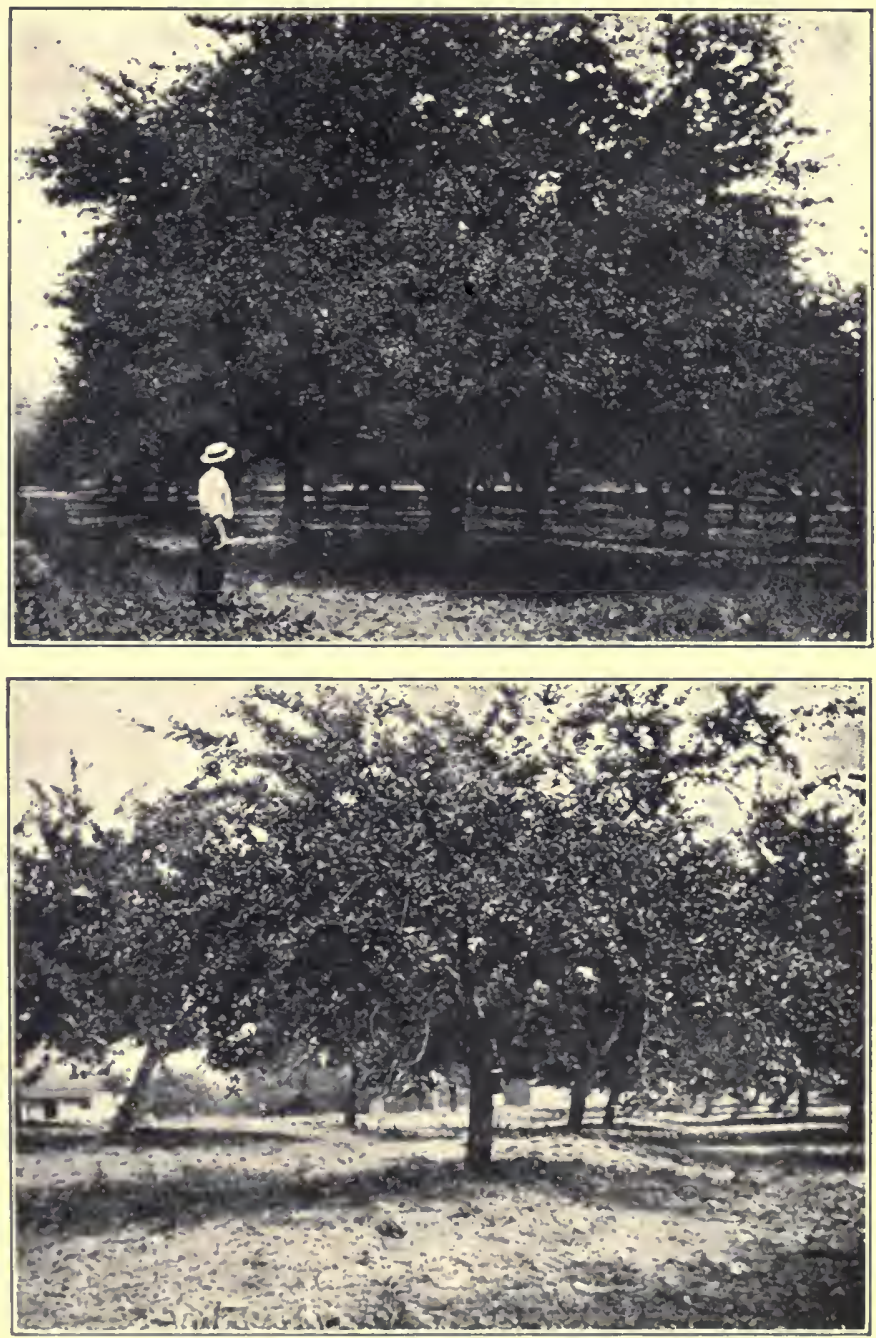

1) TWU TYPES (1F SOII.

The upper picture shows wrll-grown apple trees in good luam soil. The lower picture porre apple trees in light gravel loam. A bout 4u fears is the age of the trees in botlo cases 
provided these stiff soils have been well aerated by tillage tools, for a time sufficient to put the soil in good physical condition. The best types of wheat land carry less moisture-from 12 to 15 per cent.- than the best grass types.

Many secondary types are found.- While the mechanical analysis of soils recognizes but eight divisions, classified from the size of soil grains, the direct application to the field will show a great many more factors, since other considerations are in effect here, as the humus content, the arrangement of soil grains, the lay of the land, the ancestry of the soil, and the climatic help or hurt.

The force of this is shown where humus is added to a soil. You find two soils alike in every way. Add humus to one-the texture is changed, the water-holding capacity is increased, the productivity is made greater. You have not changed the size of the soil grains, the basal principle of type remains the same.

Another example: Take two sand soils, of the same basal type precisely, the components in both instances being the same. One is located in a section where the rainfall is abundant and where it is frequent. The other soil in a section where just the opposite extremes exist. It follows, without discussion, that other conditions being present-food, warmth, seed, and culture - the moist soil will generally produce a satisfactory crop and the dry soil an unremunerative crop.

Mechanical analysis a help and guide.-We receive assistance when we know soil types, for we have a most helpful guide here at hand. But we have no positive rule to follow in the selection of crops we shall grow. With more study, with more investigation, we may in future years predict with greater safety the behavior of 
soil under cultivation and when given certain crops that seem to fancy these special types best.

\section{Bear these things in mind:}

I. That sand areas, when properly reënforced with humus, water, and plant food, are peculiarly adapted to all kinds of truck crops.

2. That early truck crops are more safely produced when a maximum of sand and a minimum quantity of clay prevail.

3. That general or late truck crops are most safely produced when the sand type carries the minimum of the coarser and the maximum of the finer sand grades.

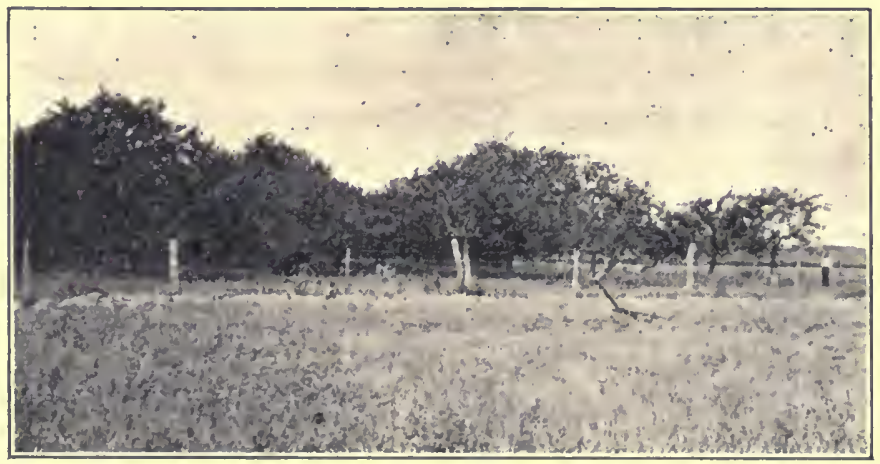

CROP ADAPTATION

An apple orchard extending from loam to clay

4. That fruit growing calls for considerable clay as a part of the sand type.

5. That the best corn crops are produced where neither sand nor clay predominates-the silt materials producing the best results.

6. That the general grain crops are best suited when furnished a silt type of soil. 
7. That wheat is most at home in soils where fine silt and clay predominate.

8. That grass fancies most those soils that carry a high percentage of clay.

9. That potatoes prefer a sand type where medium sand prevails, where silt is present in a medium quantity, and where clay is present only in moderate quantities.

Io. That with these special types must be included good tillage, humus, air, moisture, and plant food.

Soil type standards.-It is out of the range of possibilities to give definite standards of soil type for specific crops: too many conditions prevail, such as previous treatment of the land, climate, plant food, humus content, soil drainage, tillage methods, etc. The following standards are suggested in the light of known conditions-in a very general way:

I. Early truck and potatoes:

Not more than 15 per cent. of water.

As much as 60 per cent. of medium sand.

Not more than ro per cent. of clay.

About 20 per cent. of silt.

2. Late truck and fruit:

Not more than 20 per cent. of water.

As much as 5o per cent. of medium and fine sand.

Not more than 25 per cent. of clay.

From to to 30 per cent. of silt.

\section{Corn:}

An average of 20 per cent. of water.

Not more than 50 per cent. of medium fine and very fine sand.

Not more than 20 per cent. of clay.

From 15 to 25 per cent. of silt. 
4. General grain :

About 20 per cent. of water.

From 40 to 60 per cent. of silt.

From 20 to 30 per cent. of fine sand.

From 15 to 20 per cent. of clay.

5. Wheat:

From 15 to 20 per cent. of water.

From 20 to 30 per cent. of clay.

From 30 to 70 per cent. of fine silt.

Not more than 15 per cent. of sand.

6. Grass :

From 20 to 25 per cent. of water.

From 40 to 70 per cent. of clay.

From 20 to 30 per cent. of silt and fine silt.

Not more than Io per cent. of sand. 


\section{CHAPTER IV}

\section{CONCERNING THE TEXTURE OF THE SOIL}

Some soils are worked with ease, others with difficulty: plows are drawn with little resistance or with much, water enters freely or very slowly, plant food accumulates in quantities to meet the needs of plants, or so slowly

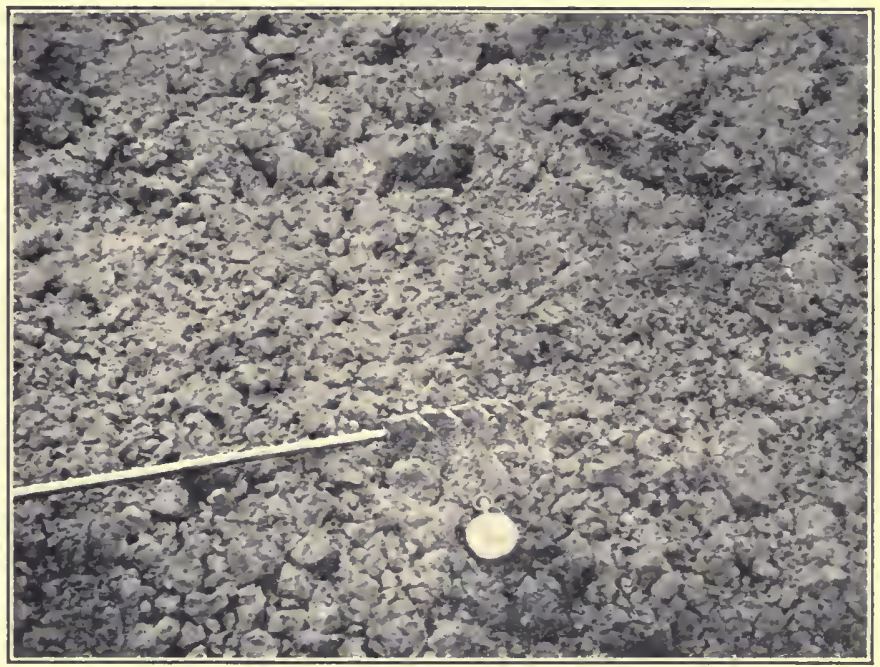

A CASE OF BAD TEXTURE

Even though much culture was given, the soil is left open, lumpy and coarse

that they are starved, seed beds are prepared with much labor or with a minimum of effort-all these conditions are governed by the texture of the soil. If you would know the power behind these activities, you need to seek no other than the soil particles. 
The manner of their arrangement, their size, their number and their structure, all enter into a clear understanding of the texture of the soil. For let this be said: the soil's physical conformation, in so far as it influences the temperature of the soil. the supply of water, and the circulation of the air, has more to do with successful plant culture than its chenical composition. There are many soils that are abundantly supplied with all the necessary chemical constituents, but, being in such a poor physical condition, they are quite unable to do any work of a serviceable nature. They are of poor texture.

Soil texture may be modified.-The texture of the soil may, of course, be modified. There is a limit to the change that may be effected, however, and time is required, also, if this is to be done. Our clay lands still remain clay lands, although man has been at work with them for thousands of years. And the same is true of sand areas, or of any other special type of soil.

But they may be modified. Organic matter, when added to soils, improves them: the clays open, air and water more freely enter and do good; the barren sands more tightly grasp soluble plant food and water, and hold them longer for growing plants. Organic matter warms the heavy clays and lessens the burning of the sands, and it increases available plant food in all.

Since it is not within the ability of a man to effect marked changes in the character of his soil, it follows that the wisest practice will be to select those crops best suited to the peculiarities of individual localities. Therefore, we shall not attempt to grow wheat, for instance, in soils of light texture-the sand types-nor garden vegetables in the clay types.

While, on the other hand, we do grow crops in all parts of the country, in all sorts and types of soil, we do so only 
with average success. When we get out of the range of our so-called common soils-those of the normal average-we meet with failure, ustually, unless the crop, because of its nature, fancies the peculiarities of that individual soil.

Air circulation.-A soil is often unproductive because there is no opportunity for the circulation of the air. Air, you know, is just as necessary for plants in the soil as it is needed for them above it. When you have a soil that is puddled readily, air is excluded and plants growing there lose their strong growing powers, turn yellow, and become either stunted or die.

Water circulation.-Water is an important component of the productive soil. Is it present in too great a quantity? If so, the plant develops slowly, maybe it dies. Is it lacking in the soil? If so, the plant behaves in the same

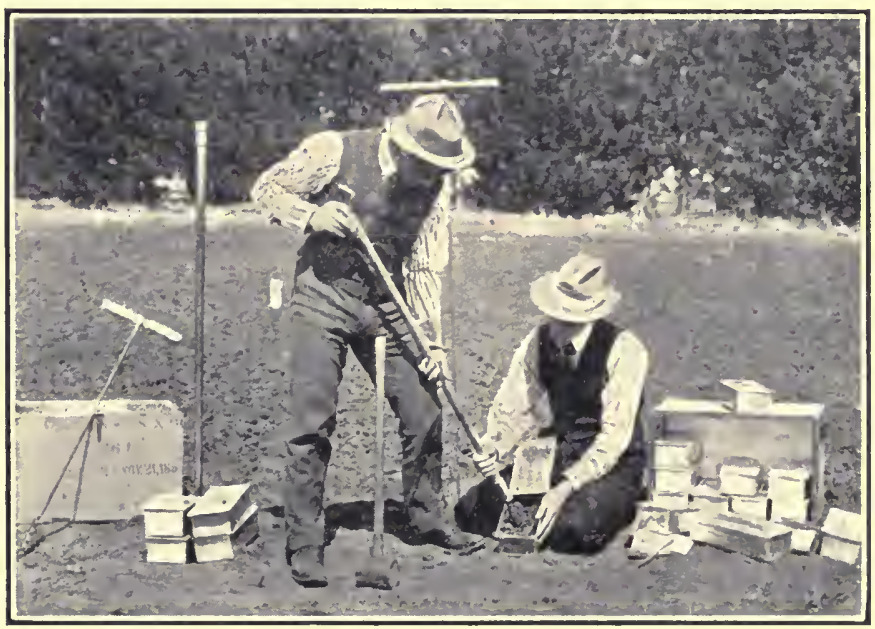

TAKING SOIL SAMPLES

A common way of getting samples for moisture determination 
way: it either never fructifies or does so in a feeble way. only. In the first case air was excluded, although much moisture was present: enough to dissolve plant food and carry it through the plant. In the second place, air was free to enter, but so little moisture was present the plant food was dissolved poorly and as poorly carried into the plant.

The pore-space of the soil.-Both the air content and the water content of the soil are governed and controlled by the pore-space of the soil. Since the soil is composed of particles of sand, silt, clay, and humus, and since these vary in size and in numbers as well as in arrangement, it follows that open spaces will naturally exist at the meeting points of these many particles. It were impossible for man or nature so to arrange these particles that no open spaces might exist. Where the larger grains predominate, large open spaces naturally result, while where the clay particles - the finest grains - predominate, the open spaces are very tiny, indeed.

The $\mathrm{n}$ u $\mathrm{mber}$ of pores is less in the first than in the second instance, but, on the other hand, they are

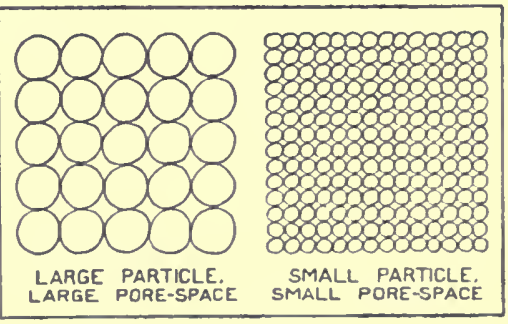

THE PORE-SPACE OF THE SUIL much larger.

The diagram illustrates the iclea. The pore spaces of sand types are larger in size but smaller in number than those of the clay types.

The water films.-When you pour water over a handful of marbles, you note that it runs off but leaves the marbles wet. In other words, a film of water, surround- 
ing each marble, has been left behind. So it is in the soil. Each particle-and there are billions in every cubic inchseizes water as it passes down into the soil and holds it so tight that only the highest heat in the drying oven will entirely release it. Consequently, every field soil has its many, many particles wrapped in a thin sheet or film of water, and even the dry dust of the road holds fast to its minimum quantity of water.

The following table shows the water content of common field soils during a period of drought-six weeks in duration :

Kind of Soil

Percent.

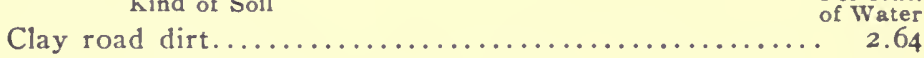

Sand-low in humus............................ 8.34

Clay-excellent for grass....................... 19.61

Silt bottom-produces eighty bushels of corn......... I2.30

These same soils were sampled later in the same season, after a period of rain of several days' extension. The water content is shown in the table following:

$$
\text { Kind of Soil }
$$

Per cent. of Water in Wet Soil

*Clay road dirt............................... 29.08

Sand $\ldots \ldots \ldots \ldots \ldots \ldots \ldots \ldots \ldots \ldots \ldots \ldots \ldots \ldots \ldots \ldots \ldots \ldots \ldots \ldots \ldots, 22.53$

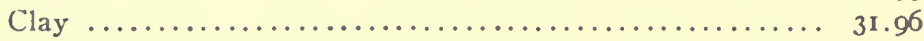

The passing of water through the soil.-The rate that water passes through the soil is governed by:-

I. The pore-space in the soil.

2. The water channels formed by the arrangement of soil particles.

3. The amount of humus in the soil.

It follows that great differences will be observed in the passage of water through soils-open soils permitting it * The road dirt was dried considerably by travel, which cut and opened
it-a process of aeration. 
to flow easily and rapidly, tight-fitting soils with slowness and with difficulty.

In proof of this, note the flow of water during twelve hours through sand and clay soils, both typical samples of the field:

Kind of Soil

Inches

Sand-good potato soil........................ 118.0

Clay-good meadow soil..................... $\quad 1.3$

Since a soil composed largely of sand is open, but little resistance is offered to the flow of water, for a tiny stream is soon formed which remains constant so long as the supply remains unchanged. On the other hand, the fine particles-these compose clay soils-act as a barrier to water as it goes downward to such an extent that only a very small quantity ever makes its way through.

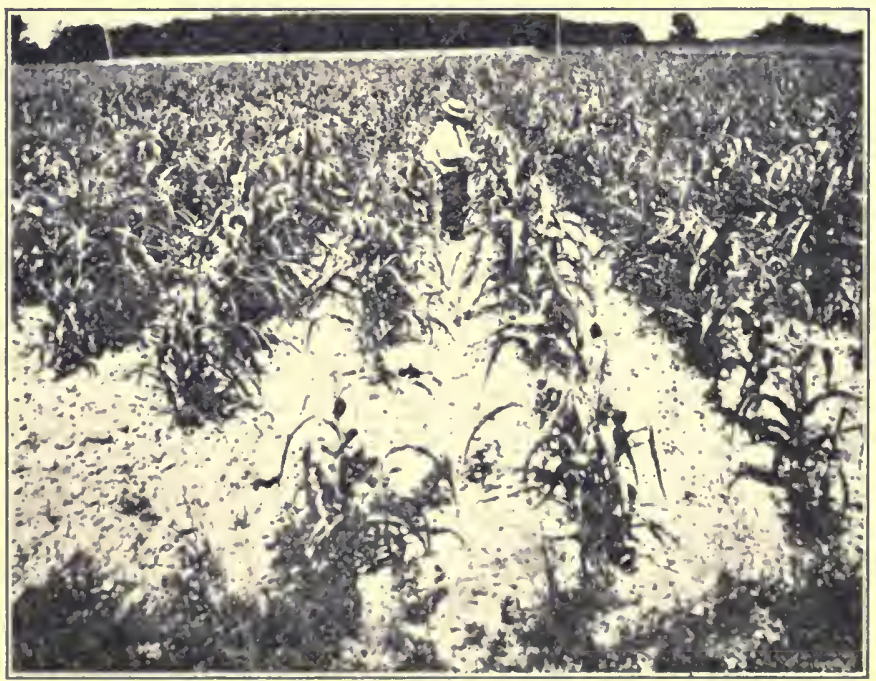

A SOIL THAT NEEDS HUMUS

To get humus in the soil is to make the first step in soil inprovement 
When humus is present in the soil in any appreciable quantity, it increases the ease of flow-at least, its absorption-for the clay types. In this respect it is manifest that humus is a valuable contribution to both these soil types. Without humus, both sand and clay are at a disadvantage, each showing the loss not only at harvesttime but throughout the growing periods, regardless of crop, or season, or section.

Three forms in which water exists in the soil.-Three kinds of water are present in soils: gravitational water capillary water, and hygroscopic water.

Immediately after a rain, gravitational water, or that which will move under the influence of gravity, is present in the soil, where it remains until it works its way downward into the subsoil or until it is removed by nat-

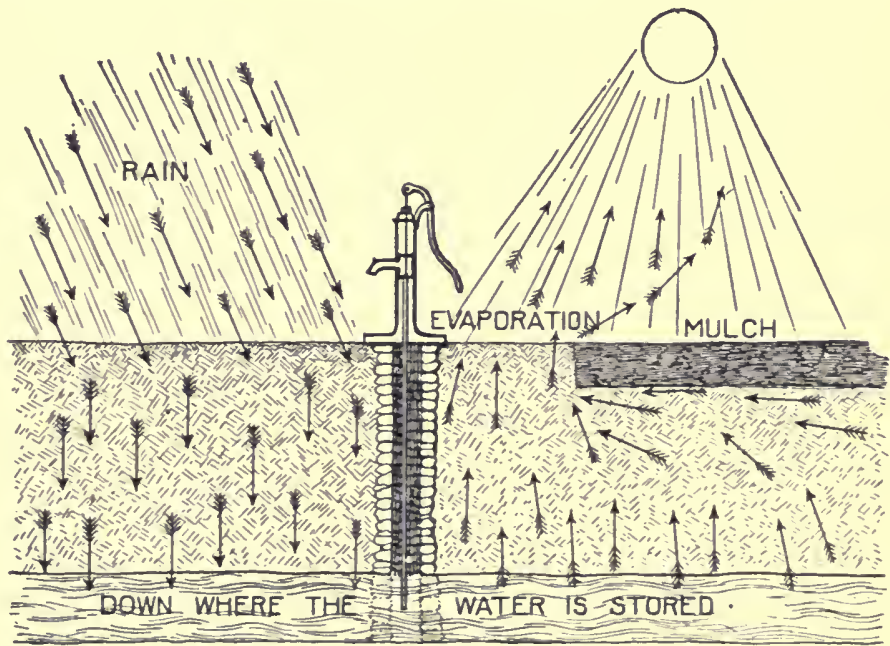

CIRCULATION OF WATER IN THE SOIL

By gravity water goes into the soil, by capillarity it circulates through the soil and upwards, and unless prevented bv a mulch, it goes out into the air by evaporation 
ural or artificial drains. You have this kind of water in all wet places-wherever water accumulates to leak or drain away only with the slowest activity, or else not to move at all.

Capillary water represents the usual supply for the growth of plants. It is the normal average-the visible water content of the soil. It is the remains of gravitational water-what is left behind in the upper soil and held as films around particles and in the finer openings. It is the water that is attracted and held fast by soil particles as its kind passed downward, enticed ever onward by the force of gravitation.

It is this capillary water that gathers up soluble plant food scattered all about in the soil, that breaks into closed storehouses where plant food is held, releases it that it may be united with the rest, so that all may be delivered within easy reach of the fibrous roots for plants to use for food and growth.

Capillary water is found in interspaces of the soil. While its natural direction would be downward because of gravitation, it really moves in the opposite direction, since the pulling force of the drier particles is greater upward. Hence, capillary water constantly moves from moist regions into others less moist. The surface of the land, being warmed by the sun and dried by the air, soon loses its moisture through evaporation, calls to the lower depths for more, and in this way replenishes its normal supply.

By this principle, soluble plant food that either existed in the subsoil or that was carried there by gravitational water, is now brought upward into the surface areas, where grow plants feeling routs, now to be used when neederl.

The minimum moisture content of the soil is known as 
hygroscopic water. Soil particles of cultivated lands allow gravitational water to escape without resistance. They permit capillary water to climb out of their reach, even to be evaporated into the atmosphere, with some reluctance, it is true, but withal, its freedom to go is granted. But the last bit of film water-the tiny covering enclosing each wee particle-is held fast-so fast that no force of gravity, no drying demand of warmth or heat or sun is able to snatch away these many little shrouds in their cntirety.

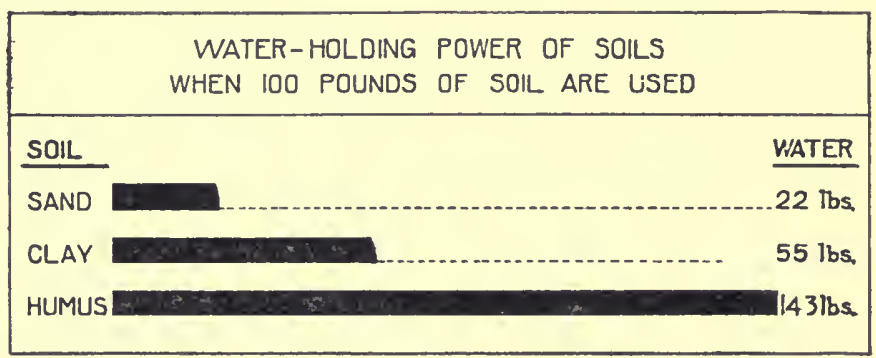

VEGETABLE MATTER AIDS THE SOIL IN HOLDING IVATER

Water-holding capacity.-When the pore-spaces of the soil are filled with water, the soil is saturated. Every bit of air has been driven out and for the time being the soil is dead. In time-if the soil has been properly handled-the excess water will be removed by gravitation and by capillarity, the soil then will be in fit condition to contribute its share to crop production; for air, you know, if good root development is to be had, is as necessary as water.

The amount of water that a soil holds will depend upon several things, the following being of first importance:

I. The nature or type of the soil:

Sand soils receive and give off water freely, clays take and give off slowly. 
2. The nature of the subsoil:

Sand and clay subsoils act similarly with surface soils: open subsoils open the top reservoir, stiff ones hold the water fast.

3. The amount of humus in surface soils:

Where no humus is present, the water content is less, since the air spaces are less in number and less able to hold. Much humus in the soil enlarges the water-holding capacity.

4. The looseness of the soil:

A loose, open soil, where humus components are present, increases the absorption power, and may increase the water-holding power.

5. The physical condition of the soil:

Where clods are present, the particles are tightly pressed together, allowing neither air nor water to enter. Open these clods, and you increase both the size and the

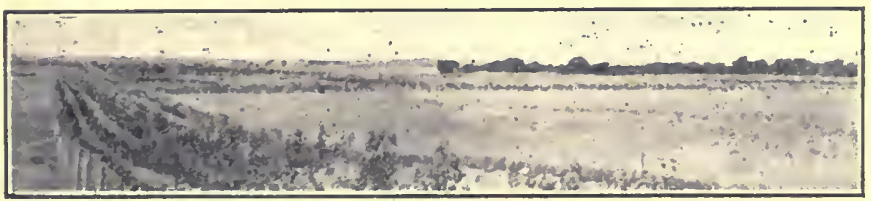

TREES IN THE PRAIRIE REGION

Summer culture saves the moisture and the trees grow

number. A soil well supplied with humus, and when fine and mellow and in goor high tilth, holds its maximum quantity of available water.

6. The method of surface treatment:

Since water escapes rapidly through evaporation, it follows that any method of cultivation that reduces this loss will enable the soil to hold its water longer. Any treatment that fails in cloing this assists in making the loss constantly greater. 


\section{CHAPTER V}

\section{HOW PLANTS FEED}

Learned men have been searching for many centuries that they might discover the elements which form the world.

Up to the present time between seventy-five and

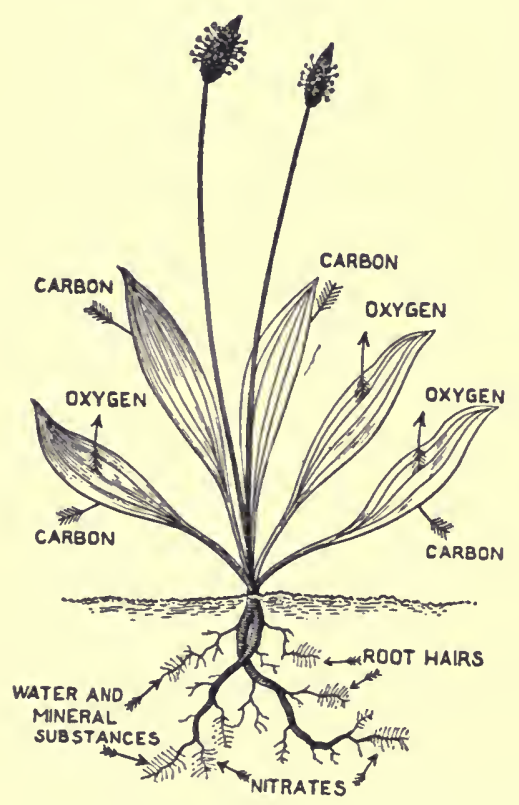

HOW PLANT FOOD GETS INTO THE SOIL

Carbon is taken in through the stomata, or mouths, on the underside of the leaf. All the mineral elements and the nitrates are in solution in the water and pass in this way into the plant through the root hairs at the tip end of the growing root. Later this same water passes out of the leaves as vapor eighty have been found in the soil, the rock, and the air ; butstrange as it may seem, only fifteen of this number are found in plants and animals, ten of which are absolutely essential to the growth of plants.

Where plants get their food.-There are just two sources of plant food: the soil and the air. The young plant beginning its life obtains its first food from the seed. With this food it starts its roots into the soil and its stems and leaves into the air. Henceforth both roots and leaves will gather food for f urther and future growth. 
The leaves take from the air carbon and oxygen.

The roots take from the soil, water (oxygen and hydrogen), potassium (potash), phosphorus (phosphates), nitrogen (nitrates), iron, sulphur, calcium and magnesium, as essential elements of plant growth. While manganese is present in small quantitics in nearly all plants, it is not an essential element, nor are sodium, silicon, aluminum, boron, fluorine, barium, lithium, and chlorine.

Composition of plants.-When all sorts of plants are mixed together and dried (all moisture driven off by heat), the following proportion of elements results:

Element

Carbon

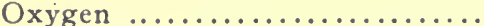

Hydrogen

Ash or mineral compounds.......

Total
Per cent. Where the plant got it 45.0 Air

42.0 Air and water

6.5 Water

I.5 Soil, air and bacteria

5.0 Soil

100.0

From this it will be seen that the greater part of all plant food comes from the air and water-only a small quantity from the soil.

Carbon is secured by the leaves.-If you partly burn a match, you observe it has become black. You now see carbon-this black substance. Every part of a plant contains carbon. Do you wonder now why this element is so important? And do you know that all carbon in plants comes from the air? The leaves of the plants gather it, not a particle is taken by the roots. Here is a great service that leaves perform: they use the carbon of the air for making starch and sugar. Without leaves or without carbon, we would have tro starch or sugar in the world in any form. We have two interesting things about this 
manufacture: none but green plants, and by them only in the sunlight, can carbon be used or starch or sugar manufactured by the leaves. Thus we find that sunlight

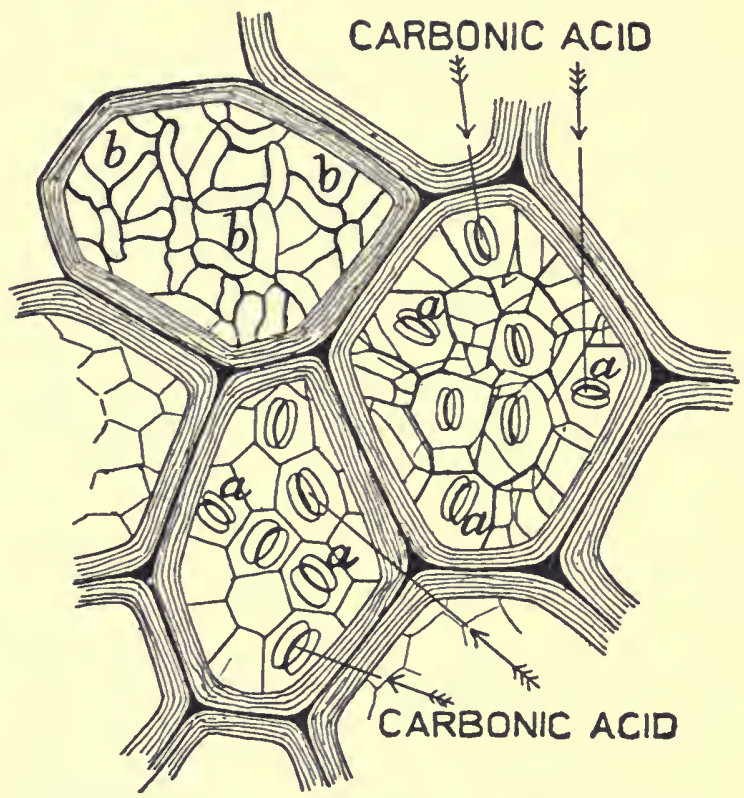

THE UNDERSIDE OF A LEAF WITH A MICROSCOPE $a$. Mouths or stomata; $b$. Cells of the leaf

is power or energy and the green coloring of leaves the machine that combine in the performance of this work.

Soil-food is secured by roots.-Before soil-food can be used by any plant it first must be put in soluble form by the water of the soil. It then reaches the plant by means of root hairs-the small, slender, delicate branches of the roots. These root hairs are the feeding organs, and 
so tiny are they as many as 38,200 have been counted on a single inch.

The large, coarse roots with which you are so familiar have nothing to do with absorbing plant food from the soil. They serve merely to conduct the sap and nourishment from the root hairs to the body of the plant. Since the root hairs are formed only very near the tips of the finest roots, it follows that plant feeding takes place some distance from the spot out of which the plant itself grows. In applying manure or other fertilizer to trees and plants, it is well to remember this fact: get the food as near the feeding roots as possible, rather than near the trunk or stem.

Roots take nourishment by osmosis.It matters not how closely you examine root hairs, you will find no pores or holes in them. It is evilent, therefore, that no solid particles can find their way into the root hairs: food in solution, only, can pass into the root. The law governing this principle is known as osmosis. You can readily understand the action of this law by a simple experiment: Take a glass tube or small lamp chimney and tightly fasten over one end a bladkler or a piece cut from one. After the bladder has been securely fastened, pour into the tube or lamp chim-

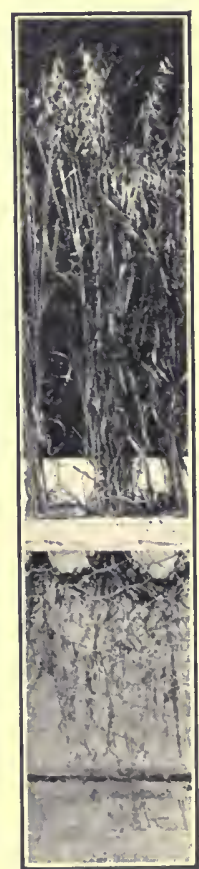

OATS

These roots do not go very deep in to the soil ney a small puantity of nulasses: now place this in a jar of water, so held that the level of the molasses inside and the water outside will be the same. lasten the tube $i$ this position and oisserve from time to time for three 
or four hours. You will note shortly after the apparatus has been so placed that the molasses in its receptacle is gradually rising above the level of the water outside. If

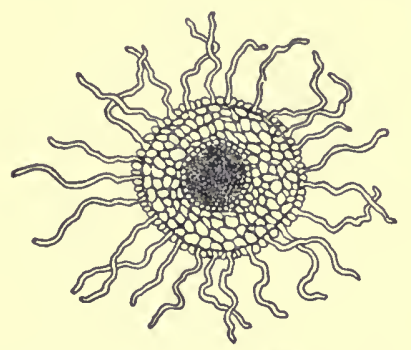

CROSS-SECTION OF ROOT HAIR you use a slender tube, it may overflow even at the top.

The increase in the contents of the tube or lamp chimney is due to the entrance of water from the outside; for the water has passed through the thin bladder, or membrane, and has come to occupy space in the tube. While the molasses seeks passage through the membrane to the water below, it does so very slowly, so slowly it is scarcely noticeable. The interesting behavior is this: There are no holes or pores in the membrane, but still there is a free passage of liquids in both directions, although the more heavily laden solution must move more slowly.

Now, root hairs behave in the manner here described. Soluble nourishmentneeded plant food-passes from the outside to the inside through the delicate membrane of the root hair. Thus does food enter the plant root. From the root hairs, foods are carried into the root. Thus do we say a root takes nourishment by osmosis.

The sap current.-Growing plants are ever busy gathering food, the root hairs - Root HaIrs securing nourishment from the soil and the leaves carbon from the air. As soon as the carbon is manufactured into starch and sugar, these manufartured foods 
must be carried to all parts of the plant. Likewise, the subștances brought in from the roots must be taken upwards into the leaves. To perform the duties two currents are required: one to carry the product secured by leaves downward, that needed food may go to the roots; and another to carry the root acquisitions upward, that leaves may not be neglected.

This explanation disproves the old notion that sap goes up in the spring and down in the autumn. This sap water, when taken up by the root hairs, is in a very dilute state. The minerals and nitrates dissolved therein are carried up into the leaves, but left behind when the water is evaporated into the air.

When the summers are dry and hot and there is but little water

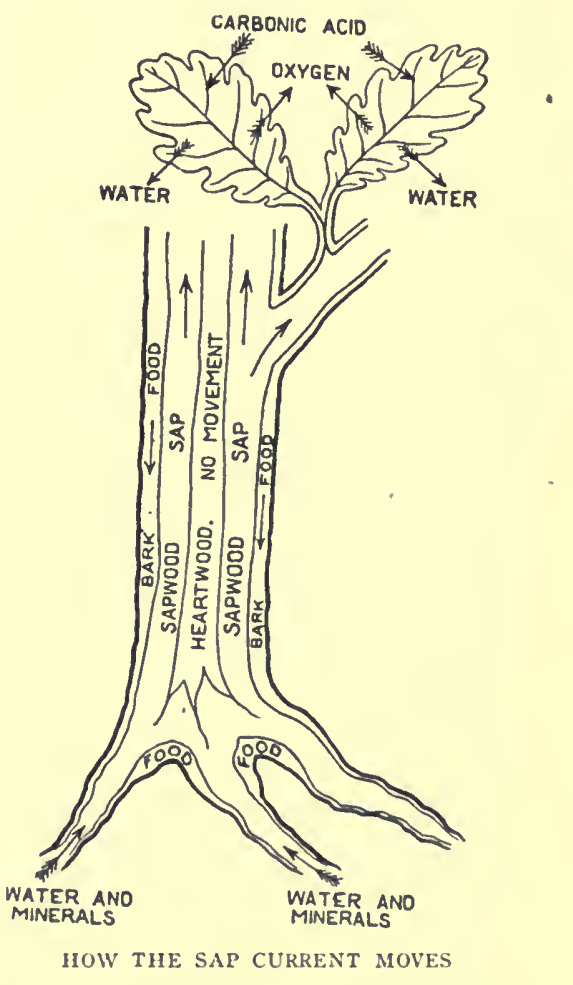
in the soil, the leaves shrink up). This is sinuply a way they have of kecping the water from passing too rapidly' off into the air. 'This withering is a wise provision after all, for when the plant closes the months or pores of the leaves, evaporation is checked until the roots can secure a supply from the soil 
below. Water is, therefore, necessary, that soil-food may be carried in and through the plant, and even to carry the leaf-manufactured products back to the roots.

The upward current from the roots passes through the woody portion of the trunk, while the downward current from the leaves passes beneath the bark.

How the plant uses its food.-A plant is a body of cells-millions of them, just like your body. These cells increase in number as the plant enlarges, grows. Every cell is an enclosed sac, holding within it the juice and other substances necessary for its enlargement and growth. The walls of these cells are made of cellulose-a carbon compound, produced from the carbon that enters the leaves from the air. When the cell is first made the cell wall is thin and tender, just as we find it in green and young plants, but as it matures the wall becomes hard and woody, and less appetizing and digestible.

These plant cells are responsible for the use of the food obtained from the air and from the soil, for the building of plant tissue and for the formation of the compounds of the plant or the fruit of the plant.

Every live, active cell contains protoplasm, the real life of the cell. When the soluble soil materials-we call these plant food-have been carried up through the long channels of cells and when they reach the leaves, they come in contact with starch grains and carbonic acid. Here these various compounds are decomposed through the action of heat, and sunlight, and protoplasm, and chlorophyl: starch is made or changed into sugar, or maybe starch or some starch derivative is united with the nitrates and sulphur in some way so that protein results, or maybe oil or cellulose or crude fiber is manufacturedeach is made just as the plant decrees.

The meaning of plant-building.-Before these elements 
were enticed into the plant they were of no value to man. He could not use them for food or for clothing; he could not use them for fuel to cook his food or to keep his body warm; nor could he call upon them for any special use.

But behold the change when the plant takes them up!

Without value in the soil and air before, now the plant calls them into use: tissue is built, which soon becomes food for man and beast; clothing for shivering or blistered skins is now provided; shelter for the strong and weak is now possible; fire for a thousand uses is now ablaze; energy for the work of the world is now available! 


\section{CHAPTER VI}

\section{THE ELEMENTS THAT PLANTS USE}

We have considered heretofore the physical side of soils: the components that make them, the size, the arrangement, and the behavior of the soil particles, the work of air and water-how each is influenced by the texture of the soil.

Our knowledge of these things has been given to us largely by the soil physicist, who, either in the field or in his laboratory. has sought to discover those laws that are concerned with the mechanical conformation. Now we are ready to learn of some of the findings of the chemist, for in his laboratory are revealed many hidden secrets, but none of more interest than those having to do with soils and plants.

A word about the element itself.-We must not misunderstand the nature of an element: it is a single thing altogether, standing by itself and alone. Water is not an element, because it is composed of two elements-oxygen and hydrogen. Table salt is not an element, for sodium and chlorine-two elements themselves-have united and salt has resulted. Wheat is not an element, nor is the air we breathe; neither are the clothes we wear, the coal we burn, the food we eat:-these are compound substances, made of two or more single elements.

An element from its very nature is indestructible. You can destroy plants, and animals, and wooden things,-all made of many elements,-but you cannot destroy the elements that compose them. When plants or animals die, when substances decay and disintegrate, or otherwise are 
destroyed, the elements that originally formed these substances enter into new combinations and go back either to the soil or to the air (from where they came), there to remain until called into service again by plants or animals for some service of the world.

Elements not in a pure state in the soil.-Do not imagine that the elements essential to plants are to be found in a pure state in the soil, for they are not. You will find only one or two in the entire list of chemical elements that are to be found in a pure state anywhere in nature's storehouses. Of course, in the chemist's laboratory you will be able to find these, for it is his work to separate the elements and to acquaint himself with their characters that he may recognize them readily when freed by him or held slave by some organized force, like a plant or animal.

These elements do not behave in just the same manner: some are poisonous to us, others are food; some may be seen and felt and tasted, while others we can neither see nor feel nor taste; some are abundant, present in every place; others are so rare we may never see then at all.

Plants use elements combined with others.- Ithen considering the elements that compose soils and plants and animals, remember, therefore, that they are not in a free and pure state stich as the chemist in his laboratory may force them to wo: they are combined always with other elements. producins by their combination the innumerable products of the world. While we speak of elements of plant food, we slould remember that such are given to the plant out of products which possess these elements. but in combination with other kinds. Tounderstand more clearly these foor substances which plants so greatly fancy and need, a brief discussin of each will follow:

Oxygen: our most important element.-With every 
breath of fresh air, you take oxygen into your lungs. So oxygen, therefore, must be a common element. And so it is-both common and abundant-more so than any other element in the world. Just think of this: one-fifth of the atmosphere, three-sevenths of all the plants, one-half of the entire solid crust of the globe, and eight-ninths of all the water are formed of oxygen, and thousands and thousands of other substances besides.

Oxygen is a gas-tasteless, colorless, and odorless. You neither can see nor feel it, nor can you taste or smell it. It is slightly heavier than air, and is moderately active at ordinary temperature, but at higher temperatures it is one of the most violent and powerful chemical agents known.

Oxygen possesses strong chemical affinity for other elementary substances: with most of these it is found in combination-fluorine excepted. These combinations are made with great intensity. 'This gas has power of supporting combustion in an eminent degree.

Here are just a few of its combinations:

I. With hydrogen it forms water-just common water.

2. With nitrogen (mixed but not combined) it forms air.

3. With silicon it forms sand.

4. With calcium and carbon it forms limestone and marble.

5. With aluminum, hydrogen, and silicon it forms marble and all the varieties of clay.

Besides these inorganic combinations, oxygen is found in all the tissues and fluids of plant and animal life-fat, starch, protein, fiber, etc.-none of which can support existence independently of this element.

Hydrogen: the lightest of known substances. - The lightest of all known substances is hydrogen: a gas 
I4 $1 / 2$ times lighter than air (hence its use in filling balloons) and over II,000 times lighter than water.

Hydrogen is tasteless, odorless, and colorless; and incapable of supporting life, although not poisonous. It is combustible-combines with oxygen and develops light and heat. It is very abundant, being an ingredient of many organic and inorganic substances.

A few of its combinations are:

I. With oxygen it forms water.

2. With chlorine it forms hydrochloric acid.

3. With sulphur and oxygen it forms sulphuric acid.

4. With nitrogen and oxygen it forms nitric acid.

W'e also find hydrogen in organic substances-protein, starch, fat, fiber, etc.

Nitrogen: the most costly of purchased plant foods.In appearance nitrogen in no way differs from the atmospheric air, of which it is the main ingredient (four-fifths of the air is nitrogen). Hence we know it to be without color, taste, or odor. In weight it is somewhat lighter than atmospheric air. It may be described as negative in its properties, for it is not combustible, nor is it a supporter of combustion. It somewhat dissolves in

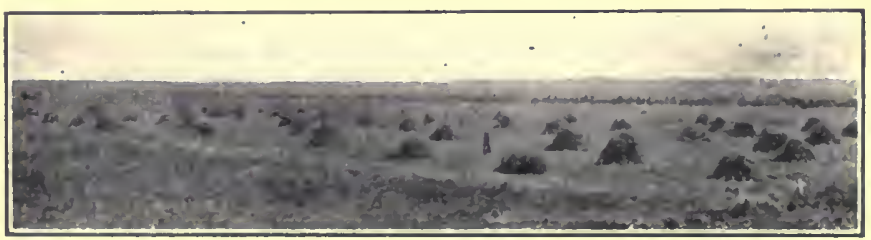

THE GREATER PART OF THIS WONDERFUL CROP COMES FROM TIE AIR

water, and its combining powers are very slight. While nitrogen is present in the air in large amounts it lends itself to the use of plants in exceptional cases, only, the 
legumes being the sole recipients of its favor, and then only through the medium of bacteria.

While it is impossible to give relative values to essential elements of plants and animals, if it were not impossible, nitrogen, undoubtedly, would be given first rank among all life-producing agencies.

Besides its occurrence in animal and vegetable forms, nitrogen frequently is combined as follows:

I. With potassium and oxygen, forming the potassium salt known as saltpeter.

2. With sodium and oxygen, forming the sodium salt known as Chili saltpeter.

3. With hydrogen, forming ammonia.

Carbon: the basic element of heat and energy.-This element is diffused throughout the world. It is most abundant in combined forms, the exceptions being: mineral graphite or black lead and the diamond-pure crystallized carbon.

We are never interested in carbon as a plant food, since this element enters from the air into the leaves. In plant and animal building, carbon is found in every constituent, hence it becomes a central element in organic processes.

In inorganic forms, among its many combinations may be mentioned:

I. With oxygen it forms the carbonic acid gas of the atmosphere, the natural waters, and the limestones.

2. With oxygen and hydrogen it forms coal.

3. With hydrogen it forms coal-oil or petroleum.

All of these substances are associated with combustion, showing that plant building is an effort on nature's part for storing heat and energy for future needs of the world.

Silicon: the sand maker.-Silicon is never found in nature except in combination. Its combination with oxy- 
gen is the most abundant solid constituent of our globe, and in less proportion is an equal necessary ingredient of the Vegetable Kinglom, while in the Animal Kingdom it occurs usually in mere traces. As sand-just common sand-it is of the utmost value in making the soil a pleasant and comfortable home for plants.

Sulphur: the match maker.-This element, while essential to plant growth, is used only slightly as a constituent of the albuminous bodies. At any ordinary temperature it exists in natıre as a solid, brittle and tasteless body of a characteristic yellow color, and insoluble in water.

Sulphur is present in the soil sufficiently to supply all the needs required of it by plants. It is extensively employed in the arts and manufactures, gunpowder and sulphur matches being conmon forms of its use.

Phosphorus : our most inflammable element.-So readily does phosphorus burn, even at ordinary temperature, it is necessary to keep it under water for preservation. Because of its inflammable nature, it is successfully used for the making of matches.

Phosphorus is colorless or slightly yellow, translucent, and poisonous. It occurs in nature in the form of phosphates or salts of phospheric acid. Without it in the soil, plants will not grow, for it is indispensable in the life process of both plants and animals.

The following may be mentioned as common forms of its combination:

I. With calcium and oxygen when calcium phosphate is formed.

2. With magnesium and oxygen when magnesium phosphate is formed.

3. With aluminum and oxygen when aluninum phosphate is formed. 
4. With humus materials when humic phosphates are formed.

Phosphorus is one of the elements usually lacking in depleted soils, and when such is the case, it must be supplied if productive crops are to be had.

Chlorine: the salt maker.-Chlorine is a gas of yellow-green color-hence its name. In weight it is about $2 \%$ times as heavy as air. When separated from its compounds, it is exceedingly poisonous, and possesses a very disagreeable odor.

While it is abundant in nature its most common as well as most important compound is common salt.

Among its combinations may be mentioned:

I. With sodium it forms common salt.

2. With calcium and oxygen it forms chloride of lime.

3. With mercury it forms corrosive sublimate.

4. With ammonia and hydrogen it forms sal ammoniac.

Chlorine is found in all plants and soils, combined with other elements.

The metals: potassium, sodium, calcium, magnesium, aluminum, and iron.-The chemist divides the elements into two groups: the metals and the non-metals. We have just discussed such non-metallic elements as are used by plants. We are now to say a word about the metals that are closely associated with plants.

Potassium.-This element is of a bluish-white color and presents a strong metallic luster. It has a very great affinity for oxygen. While potassium is somewhat widely diffused, it does not exist in a native state-only in combination with other forms. When thrown on water, potassium takes fire.

In the early days before the soap factory came, water was passed through wood ashes, thereby dissolving the potash and leaching the same, to be collected and later 


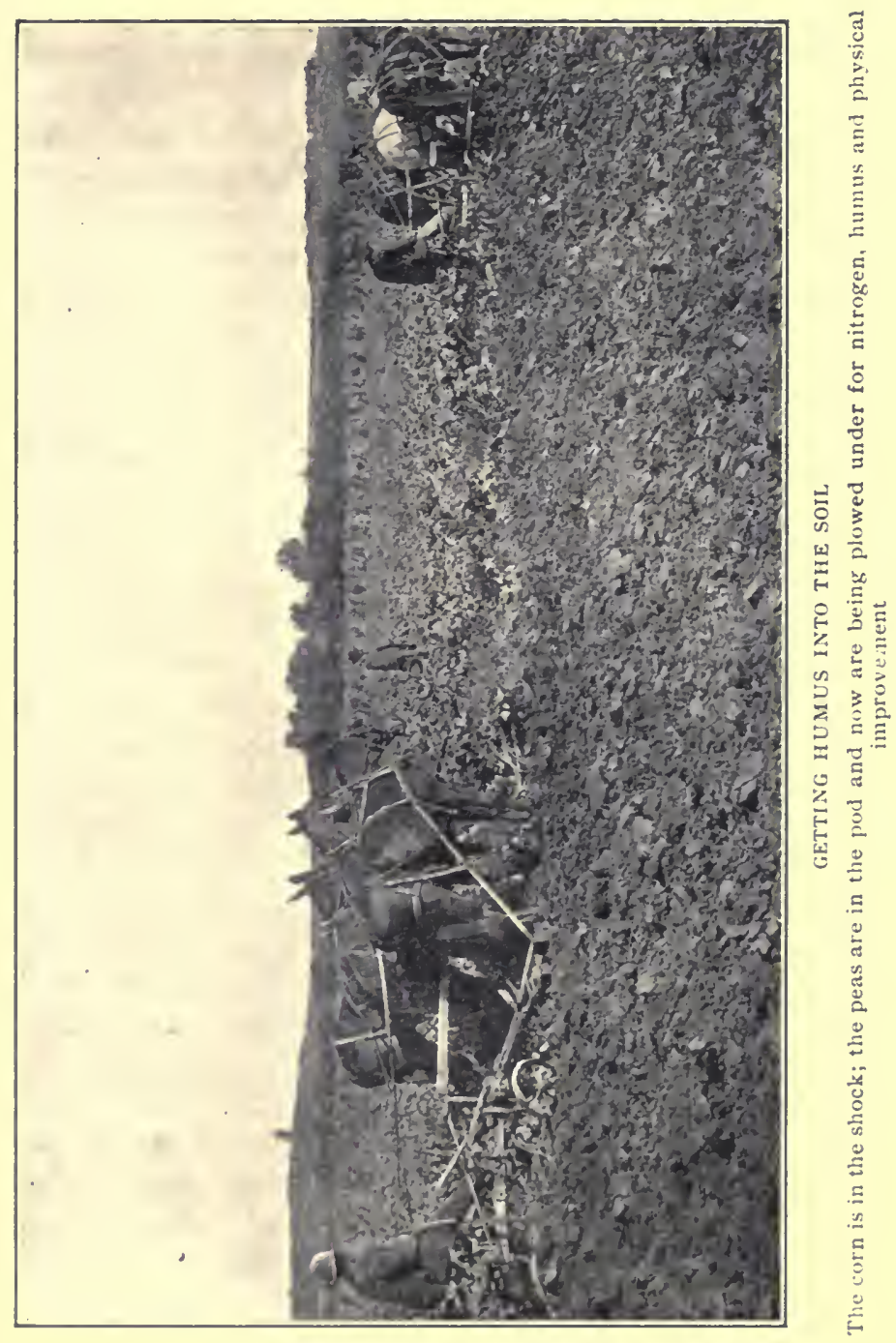


to be made into soap. This is one bit of evidence that potassium is present in plants in considerable quantities; and hence nust be present in the soil.

Common forms in which potassium unites:

I. With chlorine forming muriate of potash.

2. With sulphur and oxygen and aluminum forming alum.

3. With nitrogen and oxygen forming potassium nitrate (saltpeter).

Potassium is often lacking in soils. It is one of the three elements - the others being phosphorus and nitrogen-most often purchased in commercial forms to reinforce the insufficient quantity in the soil. In the arts and manufactures the potassium compounds are very important, being used in glass making, soap making, in fertilizers, and in many drugs and chemicals.

Sodium.-When isolated from its compounds, this element is waxy, white, and so readily oxidized that it acts violently upon water, and so to be preserved must be kept under petroleum or some similar liquid. It is present in the soil in sufficient quantities to supply all needs of the plants for it. We know this element as an ingredient of common salt, of sodium bicarbonate, or soda-just plain baking soda, of sodium carbonate or sal soda, and of caustic soda.

Calcium.-This element, when united with oxygen, forms lime. It is pale yellow in color when separated from its compounds. The following are its principal compounds: Calcium carbonate or limestone, calcium sulphate or gypsum, calcium fluoride or fluor spar, and calcium phosphate or apatite.

Magnesium.-A light silver-white substance, essential to plants. Commercially we know of it by its compounds: Epsom salts as a medicine, talc as a skin pow- 
der and meerschaum as an earthy material. Magnesium powder burns with a strong, active light, and is used for flashlights with the camera.

Aluminum.-This light metallic substance is familiar to all, since its employment in making useful things of all kinds: for the kitchen, the nursery, etc. It is remarkable for its resistance to oxidation. It is found in all clays, and thus forms a large part of many of our soils. Iron.-We all know this element. It is the most common and most useful of our metals. It is also of common occurrence throughout the earth. It combines readily with oxygen, as iron rust, hence the brown and red color of fields where much of this element is present. Iron is readily oxidized (rusted) when moisture is present. The farmer is never called upon to supply this element as a fertilizer, since it always is present in the soil sufficiently to supply the needs of plants. 


\section{CHAPTER VII}

\section{HOW PLANT FOOD IS PRESERVED}

If you think Nature is not careful of her securities, or that she is not mindful of the many deeds of trust she holds, or if you think her gifts to man a sort of "hit or miss" donation, you will quickly change this view when you begin a study of the

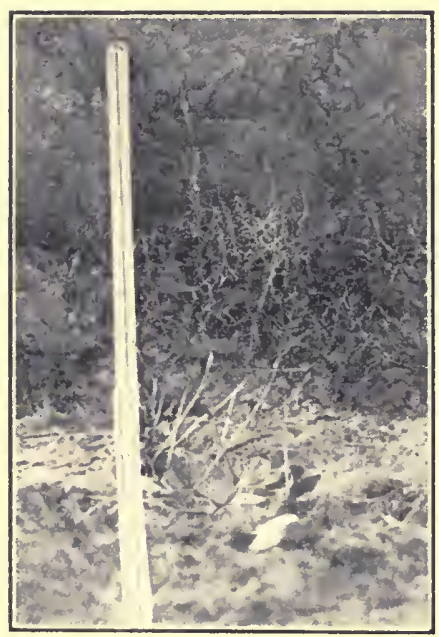

THE COTTON PLANT ABOVE AND BELOW THE GROUND

Both leaves and roots are at work gathering food for growth way she has taken care of her soil possessions. For this is true: not for a generation, nor for a century, not even for the reign of a nation, but Nature must provide for centuries and centuries, for millions and millions of years, that all the people may have food and raiment and a thousand comforts as well.

The plant the medium. -Nature makes the plant the medium through which this work is to be done. By sending roots into the soil and leaves into the air, elemental substances are brought together, arranged and formed into organized things, into plant tissues. Of course the sun, with its heat and light, is the great energizing power behind this throne of effort, but the plant is the 
agent that does the work. Elements, heretofore inert and inactive, are gathered together during the process of growth and are now associated by growth activity. Thus the elements become available food or stored energy for animal life, which in its turn and in its realm carries forward the work of the physical world. W'hether or not the plant is utilized by animals, it performs its function; for in its growth, maturity and decay it exercises, as has been shown, a profound influence in the formation and amelioration of soils. Liut whether it goes directly back to the soil by decay, or indirectly through the animal, the elements return to the soil and the air from which they were originally drawn. While the organization has been destroyed, not one single thing has been lost: all is retained for future duty in the world's work.

Plant food shifted but never lost.-So plant food is ever shifted but never lost. On the mountain top to-day, but to-morrow it may be in the depths of the sea. In the soil, useless it may be one ycar, but c'er the summer's sun has passed again, it has been locked for a bricf space in grain or fruit or forage, gathered here and garnered there until animal life has picked again its organized state to pieces: when back to its original elemental form this same material goes again.

Not all elemental material is used.-Do not think that all the earth and air is engaged in this constant transitory condition. This is true: only a part of the earth and air are thus engaged-just a wee bit, in fact. The greater part of it, more than ninety-nine parts of every one hundred, is never used at all. And why? Simply because Nature has chosen that way as the manner in which her work shall be done. For she is wiser than you may think. Suppose she had allowed all the earth and all the air to be usable food for plants and beasts and men: would it 
be here to-day? When we find it so difficult to hold fast to the little that has been given us, do you think we were able to care for plant food in all its entirety, had it been zwen into our keeping? If man knows not how to use s one talent. shall he be given two?

Let me assure you of this: it is better that things are as they are, for harl they been different. had all the plant food been just ready to use from the very beginning of time, then long before this the sea had gathered it up: to have it and to hold it, until its bottoms had been filled and its banks had been broken; until new sea beds had been formed, until the old reservoirs had been robbed of their holdings by wind and air--plant food should be urgently required else all life would be lost; else the entire world would be ruined and destroyed.

How plant food is held.- We gather from this that some plant food is available for use, and some of it is not. We may say then that three forms of plant food exist in the soil.

These three forms are:

I. Available plant food.

2. Not-immediately-available plant food.

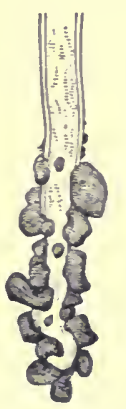

A ROOT HAIR WITH SOIL ATTACHED
3. Tightly-secured plant food.

Let us now examine these forms individually. Available plant food.--You have, doubtless: seen nitrate of soda or wood ashes. Both of these materials are used to make plants grow; for this purpose they are purchased. They are plant foods. The nitrate of soda or wood ashes are used because the nitrogen or the potassium contained therein is in each case available plant food; that is, growing plants will be able to use the material just as soon as it gets mixed with the soil grains and wetted with 
the soil water. The plant food-nitrogen and potassium contained in these materials-at once goes into solution; the soil water dissolves these two elements out of their compounds and both enter the roots of plants as rapidly as either is called. If just a small quantity of either mate-

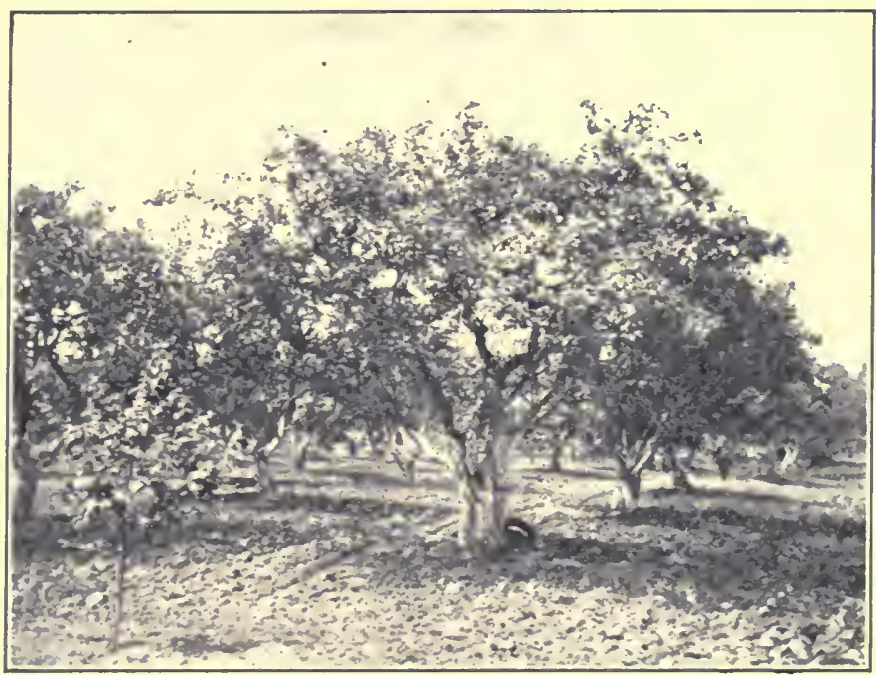

MAKING PLANT FUOD AIAILABLE

The farm orchard is neglected too often. Some people cultivate their orchards every year, and by so doing get the helpful influences of tillage

rial had been given the soil, the entire amount added might have been gathered in by the plants there growing in a single season, but if more than that required had been applied to the soil, then, the surplus would remain there for succecting crops, or it would be lost by the winter's leachings in case the soil and subsoil were open and sandy and deficient in humus-the guardian and protector of the available plant food. 
Available plant food in the soil is small.-Even in very fertile soils a great deal of available plant food is never present. Available plant food comes and goes; especially is this true with soils having poor texture and poor physical conformation. There seems to be a certain possible limit, depending on the condition and the treatment a soil has been given previously. When this limit has been reached, available plant food passes into some insoluble form that loss may be ever kept within reasonan organized retreat, rather than an utter rout.

Soils abundantly supplied with vegetable matter are the least susceptible to this changing state. They hold plant food better and longer, so long, in fact, as the vegetable supply is kept replenished. These humus soils, when favored originally with all needed mineral materials, lead in the race of high production, other things being equal, like water, heat, tillage, and correct management.

How much plant food in the soil?-Since nitrogen, phosphorus and potassium are the elements, as a rule, lacking in the soil, we need consider them only in estimating the plant-food content of any soil.

To illustrate this point just a bit of evidence will be produced. The data below, arranged by Roberts, present the case: Average analyses of 49 soils: Nitrogen, 3,053 pounds; phosphorus, 4,219 pounds; and potassium, i 6,317 pounds. These quantities are present in each acre, the depth being twelve inches.

The not-immediately-available plant food.-Passing now to the second form in which plant food exists, we have that which is unaffected by the dissolving effects of soil water-soil water, you know, secures the available form at once or very quickly - and only slightly by the acids exuded by the roots. This not-immediately-available plant food, in so far as the present crop is to be fed, 
has no concern, for it contributes no food for the plant. Perhaps it helps a little; but so slowly, so niggardly, so begrudgingly, its help needs not be included, as a rule, in immediate results.

An example of this form.-Fine ground phosphatic rock-untreated with acid-is a good example of this second class-this not-immediately-arailable plant food. 'True, this rock has been ground and maybe as finely as practical grinding machines are able to do it. Still, plants

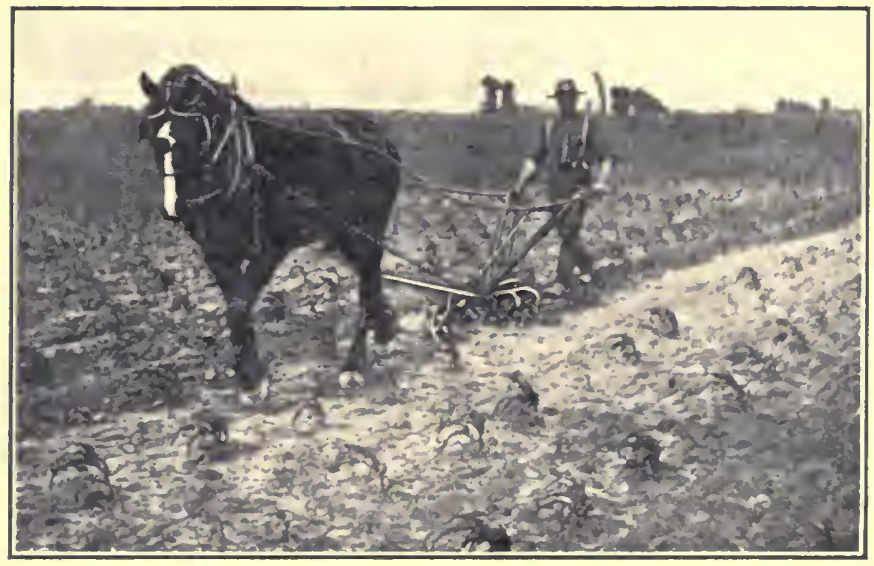

AT WORK IN TIIE CORN-FIELD

Cultivation is helpful in rendering plant fool available

are unable to use it. fine as it is, for plant roots, you know, never entice particles into their tiny cells: they take only dissolved materials. Hence this fine sround rockneeded though it may be by the very plants that reject itis still mere unavailable plant food. And so it will remain until air and water. or heat and cold. have tried their pulverizine. disintegrating powers. until their forces have crumbled it and humbled it into dust-then, 
and not till then, will this material (in any considerable quantity) pass into solution and into available plant food.

Of course, the same effect may be accomplished in other ways and in quicker ways: by employing acids, for instance. And this is clone, and on a very large scale in many of our commercial fertilizer factories. The huge crushers take the rocks as they go from the beds in the earth, they twist and turn and roll and pound them until they are broken into pieces; and then the dissolving by

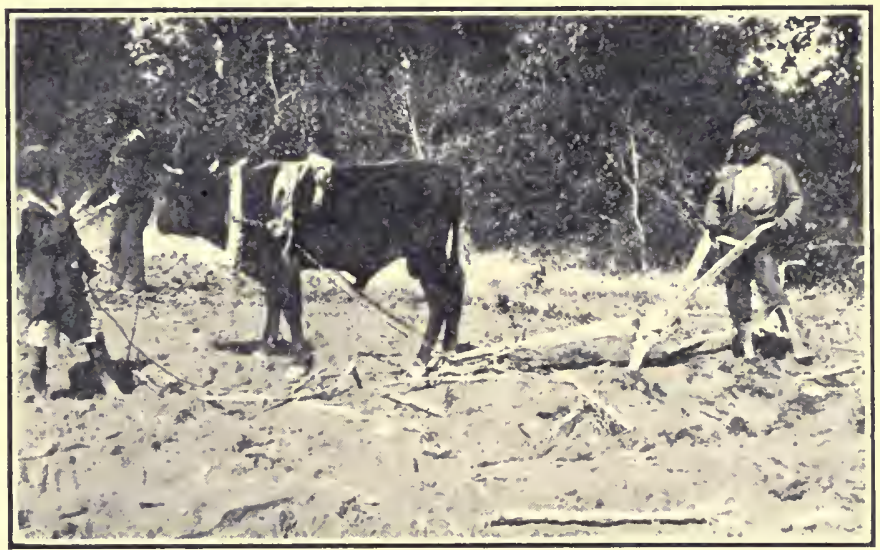

GETTING READY FOR COTTON

Cotton lands need good tillage and humus more than fertilizers

sulphuric acid follows. Before this the ground rock resisted; feebly, now, a part of it gives up and becomes plant food-available plant food.

In this instance man's contrivance has done more in a week than Nature, unaided, would be able to accomplish in a century. With her own acids, man sometimes requires Nature, herself, to do his will. After all, this form of plant food as it exists in the soil is not for the present 
day; it is for the morrow. It is the inside material that is being prepared and manufactured slowly, that it may be made a part of the soil's labor and commerce, and that it may be available at some future day when it will be called into use.

Making this kind of food available.-To help in this work you can do these things:

Till the soil frequently and well.

Cultivate when needed, using judgment and forethought.

Keep vegetable matter in the soil.

Tillage will admit air and water to lower depths in the soil. These agents, in themselves, will do wonders in changing this heretofore unavailable plant food into available forms.

Correct culture will do the same: for it allows these same busy bodies to carry on their weathering processes even though the soil be dry or moist or cold or hot.

The tightly-secured plant food.-The third class, or that form in which plant food is tightly secured, occupies the greater part of the storehouse of the soil. Here are the rocks and the boulders; the many materials that plants never use find rest and shelter within this clothing of the earth: and not a bit of it is available plant food, not a bit of it will be plant food for ages and ages and ages to come.

Use the strongest acids known and they will act but slowly on many of the materials herein sheltered or hid away from water and air. What headway may plants be expected to make against these giant forms? Not much, truly. liut still rentember this: In the beginning the earth was rock-nothing but rock, and yet plants did conquer. And so in time, aided by other good soil makers, they will conquer every stubborn rock that finds 
its way into the surface soil. The water will help, and the air will help; so also will frost and heat do the part that should be done by them: all these will work together, just as they did millions of years ago when all was in the beginning, just as they have worked always and even as they are working now.

It's Nature's way.-And this is as it should be: for there must be plant food for the use of the world when another million years shall have rolled around. It were not right for us to have it all. Fast secured it is and fast secured it will remain. It's Nature's way of providing for all the plants and animals and peoples that in time shall come. 


\section{CHAPTER VIII}

\section{GETTING ACQUAINTED WITH PLANT FOOD}

The elements usually deficient in the soil are nitrogen, phosphorus and potassium. All others are found in quantities sufficient for the needs of the plant. In some soils lime has proved of value when added, largely because of its infuence in sweetening the soil, and sometimes because it may be needed as food substance.

Our early faith in chemical analysis. - When chemistry was directed toward agriculture some sixty years ago, and when a great deal of attention was devoted to analyses of soils and plants, it was believed that much light was thrown on the many problems concerned with soil fertility. And such was the case. The soil and plant analyst gave the world much information that served both as a guide and as a help in solving some of the mysteries of soils and plants.

We had a great deal of faith in the analyses of those early days. For was it not reasonable to suppose that when you analyzed the plant, ascertaining its many constituents and substances, and then when you analyzed the soil, you should be able to judge, and to know within reason, just what element was required for any soil for the maximum yield of the crop?

The plant, therefore, was analyzed, a careful study of the elements composing it was given, a comparison of these chemical studies with plants of the same kind, though grown in other soils, was made; in short, it was carefully determined just how much of each and of every kind of elements essential to plants was withdrawn from 
the soil, when both full and average and meager yields were secured.

Naturally, it was concluded that when the full crop was obtained, all elements of food were, of course, present, and therefore every requirement of the plant was available and provided; that where light yields were obtained, some element or elements was present insufficiently for the fullest development of the plant. Consequently, if you would overcome this difficulty, you had only to take a sample of the backward soil that its analysis might be secured and then the truant element would be discovered. With this done, its duties might be provided through the addition of the element in some other way-by chemical manures, most likely.

What was later revealed.-Some surprise followed the analysis of soils, for high productive soils often showed no greater plant-food content than the most miserable producing ones. And this was just the same when a like crop was seeded on similar soil types.

This naturally caused surprise and further investigation. All sorts of soils were then analyzed and all sorts of plants. The same results were obtained; as a rule, however, the best producing soils contained a large quantity of plant food, the low producing soils a smaller quantity. When calculations were made, it soon was discovered that great quantities of plant food, even in the most unproductive soils, were present; quantities so great that in but a few inches of surface soil, enough plant food was there at hand to make maximum yields, and these yields for hundreds of years. When these same soils were seeded to crops, however, light yields invariably resulted, despite the fact that chemical analysis showed that every kind of plant food was there and it was there abundantly -an hundred times as much as the plant required. 
The gap between laboratory and field tests.-No one realized these discrepancies more quickly than the early investigators themselves. But they could not explain them. They felt they were working in the right direction, but the results of the laboratory and those of the field often failed to find a common meeting point; often the laboratory results indicated high producing qualities, but

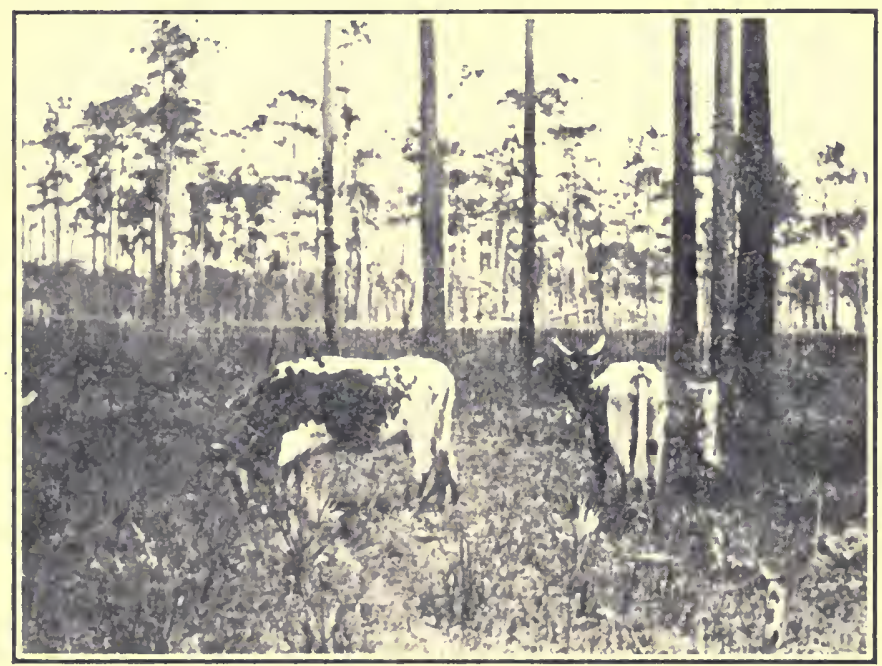

POOR GRASS, POOR CATTLE

This soil is deficient in available plant food and humus

the actual field results showed decided negative results; often the laboratory results indieated only mediocre crops, yet at harvest time the fielels showed entirely opposite results-full crops, as good as the best.

The explanation is here. - In more recent years an explanation has been sugeresterl. It is this: Every soil contains two kinds of plant food: usal)le, such as plants 
secure without difficulty, and unusable, such as is enclosed in the storehouse of rocks and particles and componnds. The soil analyst is not able to distinguish between these two forms, with sufficient accuracy to tell exactly what the plant may need at any given time. Neither his crucible nor his acids will help him, in any certain degree. When the test actually takes place in the field, the story is there told with language of no uncertain meaning. In a previous chapter the kinds of food were mentioned: avaliable, the not-immediately-available and the tightly-secured plant food.

Of course we cannot expect chemical analysis to show the differences between these forms. We are able only to determine the total amount of food present: the potential plant food, the food that is now and shall be available some day hereafter, as food for plants. An old notion is still held. A great mass of people still believe, that all that is necessary to know how to handle a soil is to secure its analysis that the plant food content may be ascertained. But, with our present knowledge, let this be accepted as certainty: the chemist can determine only the total quantity of plant food in the soil: the usable plant food plus the unusable plant food. And he cannot tell you whether it is available food or otherwise. It will be necessary for you to seek elsewhere than the laboratory for direction.

Analysis will help to some extent.-But an analysis of the soil may do great good. It may indicate in what direction improvement lies: whether tillage only is necessary that dormant supplies may be called into use, whether organic manures are best that the humus content may be increased, or whether mineral manures are likely needed that they may reënforce the plant food already present. While it is true these are indicative only, 
their value is most noted when judiciously weighed and interpreted.

Investigation along this line indicates that a most important character in soil analysis is calcium carbonate, the lime carrier.

The following suggestions seem in accordance with this fact:

1. When calcium carbonate is scanty in the soil, liming the land is advisable.

2. When calcium carbonate is scanty in the soil, acidmade manures, like acid phosphate, super-phosphate, ammonia sulphate, are inadvisable, and manures, neutral in nature, like basic slag, ground bone, wood ashes, and nitrate of soda, should be used.

3. When calcium carbonate is plentiful in the soil, then the acid-made manures may be used.

4. When calcium carbonate is abundant in the soil, nitrification of organic matter will take place rapidly.

5. When calcium carbonate is abundant in the soil, useful bacteria will develop with ease.

Analyses should be extensive.-An isolated soil analysis is seldom satisfactory for the simple reason there is no standard of comparison. All values result through their measure with other standards. We get the great bulk of our knowledge by comparison. Every isolated subject is valueless unless it can be compared with some known quantity. For this reason, an isolated soil anal$y$ sis is without value unless it can be compared with the known value of some other soil analysis. For this reason, then, soil analyses ought to be extensive and general, rather than isolated and haphazard. Such a system will give us general standards that will be valuable with every comparison.

Analyses of soil and subsoil should be made.-When 
making a soil analysis, both soil and subsoil should enter into consideration, for the variation between these two, in chemical compounds, may compensate sometimes one

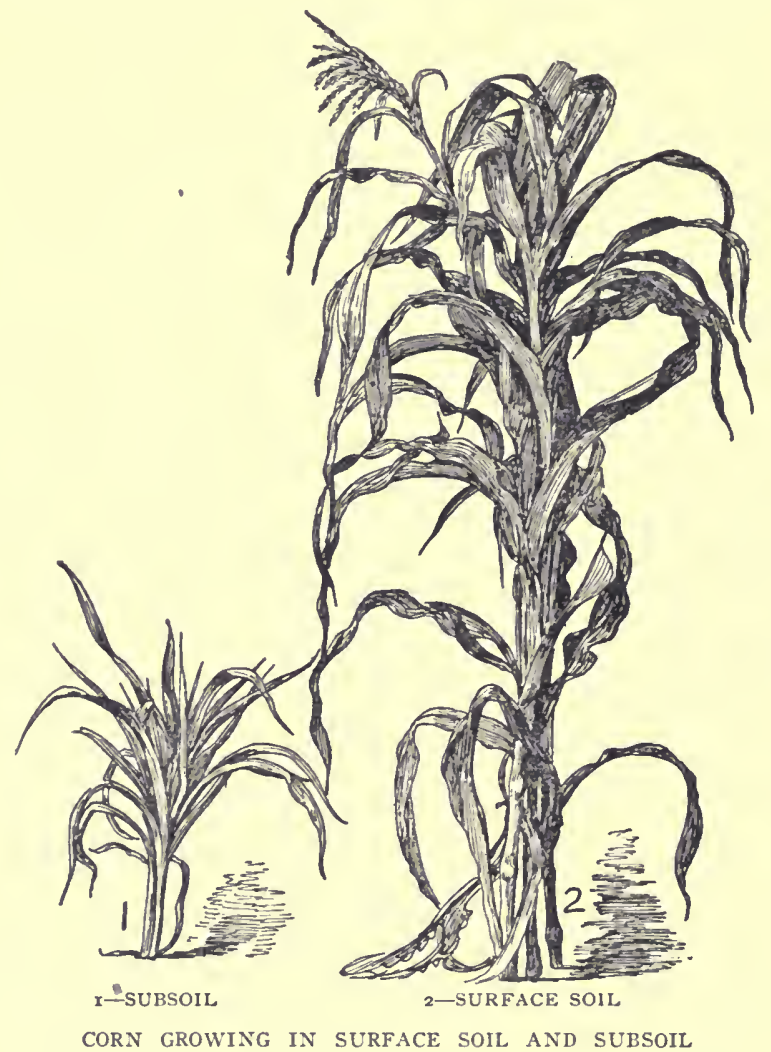

There is practically no growth at all in the raw subsoil

for the other. If a sand soil were analyzed, it might show very meager possibilities for crop production and especially this might be true if the subsoil were likewise of a sand nature, and at some depth. If, on the other 
hand, just beneath the upper eight or nine inches of sand soil, a subsoil of clay formation were present, it follows that different conditions, of course, are ever at hand, so that a lack of any soil constituent in the soil might be furnished by the subsoil and, what would indicate, by analysis, a poor, or even barren soil, might, in fact, be a most productive one. This shows the necessity of con-

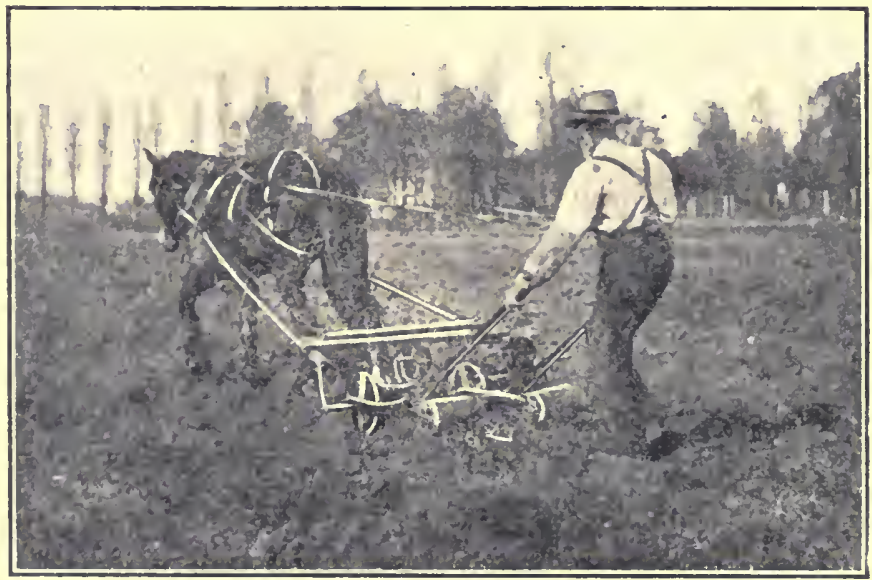

A BEET DRILL AT WORK

Seeds are put into the ground and the soll compacted that moisture may be at hand to germinate the seed and to supply the needs of the little plant

sidering soil analysis from a broad standpoint, that every phase of the subject may be inclucled.

The condition, as well as quantity, must be known.Furthermore, the condition of the plant food must be given its proper weight. fully as much as is given the absolute quantity of plant food. An analysis might show that nitrogen, for instance, is present in the soil as ammonia or as nitrates. The latter would be more readily 
usable by the plants. Then, too, if it were known that the plant food were held in a soil that is finely powdered, of good physical condition, well supplied with water, bacteria, and all factors incidental to the growth of this supply, we should prefer to stand our chances with a soil of this nature, with plant food in this condition, than where all opposite conditions were present.

Observe the soil itself.-If you would get acquainted with this hidden plant food which you cannot see, you must take the soil, itself, into your confidence and then continue to observe the soil in the fields; to watch it as it produces crops of this nature and of that nature; to see how it behaves in summer and in winter or in wet seasons or in dry seasons: in short, you must not neglect this constant intimacy with the soil out of doors, as it does the work satisfactorily, or as it tries to do it under the circumstances with which you have enclosed it.

With this training, which you must give yourself that you may learn to observe and to know the soil, and to reënforce the best knowledge by such information as general soil analyses-not in isolated cases, but of soil groups or soil types-you should be able so to acquaint yourself with your soils that you may know the best way of handling and treating them for each and every crop. 


\section{CHAPTER IX}

\section{THE POTENTIAL PLANT FOOD: ITS STORES AND NATURE}

Just as soon as it was determined that a mere chemical analysis of the soil would not reveal the element or elements lacking therein, a study of the way in which different crops used the food elements was undertaken.

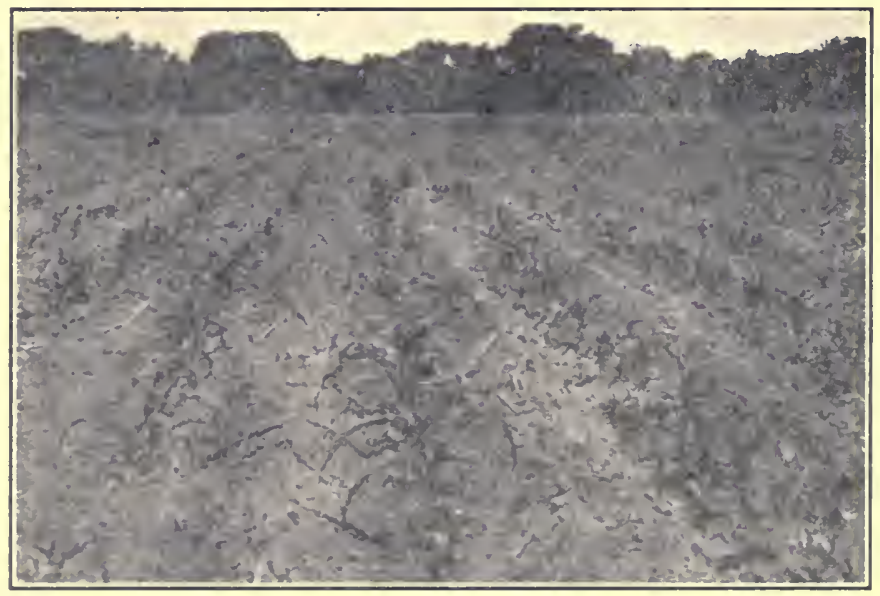

A CRU' THAT CALLS FOR MUCH NITROGEN

Corn makes heavy demands on the nitrogen stores and does best when in rotation with the legumes

This study soon showed that all plants used the same kinds of food, incorporating these foods in their body tissues, and, also, that these foods were used by the different plants in varying proportions: some using a 
good deal of nitrogen but little phosphorus and potassium, others using but little nitrogen but much phosphorus and potassium, and still others much potassium but little nitrogen and phosphorus, and other plants using these foods in still other proportions. As individual plants were studied, it was observed that some plants used one or more food elements that each particularly fancied, and while each used the other elements, it did so very modestly, and, when compared with its favorite dish, often very shyly, indeed.

Some variations in food requirements.-To prove that these variations in food requirement are real, we need to examine only a few plants-just four of our leading cereals.

The table following shows these variations with four crops-each one being partial to a different combination of food elements :

\begin{tabular}{|c|c|c|c|}
\hline Crop* & Nitrogen & Phosphorus & Potassium \\
\hline Corn............................ & $77 \cdot 2$ & 22.8 & $64 \cdot 3$ \\
\hline wheat $\ldots \ldots \ldots \ldots \ldots \ldots \ldots \ldots \ldots \ldots$ & 31.6 & $9 \cdot 7$ & 17.9 \\
\hline Oats $\ldots \ldots \ldots \ldots \ldots \ldots \ldots \ldots \ldots \ldots \ldots$ & 31.9 & $x .6$ & 36.1 \\
\hline Barley...$\ldots \ldots \ldots \ldots \ldots \ldots \ldots \ldots \ldots \ldots$ & $45 \cdot 5$ & $15 \cdot 3$ & $5 x \cdot 4$ \\
\hline
\end{tabular}

This table shows that while corn is a heavy feeder of nitrogen and potassium, it is certainly modest in its demands on phosphorus. The table shows, also, that when wheat and oats are compared, that the call for nitrogen is practically identical with the two crops, but that oats call for about 20 per cent. more phosphorus and I Io per cent. more potassium than wheat.

* On basis of average yield per acre in United States. 
In the case of barley, potassium is most in demand, with nitrogen not far behind, and phosphorus within the minimum range.

Let us express these demands in terms of proportion, using nitrogen and 100 as the units of comparisons for each crop: we get:

\begin{tabular}{|c|c|c|c|}
\hline & Nitrogen & Phosphorus & Potassium \\
\hline Corn................... & 100 & 30 & 83 \\
\hline Wheat $\ldots \ldots \ldots \ldots \ldots \ldots \ldots \ldots \ldots \ldots$ & 100 & 30 & 56 \\
\hline Oats.$\ldots \ldots \ldots \ldots \ldots \ldots \ldots \ldots \ldots \ldots \ldots \ldots \ldots$ & 100 & $3^{6}$ & 110 \\
\hline 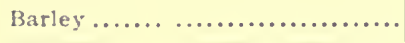 & 100 & 33 & 113 \\
\hline
\end{tabular}

These variations appear still more noticeable when we use the nitrogen of corn as the sole unit of comparison: we get:

\begin{tabular}{|c|c|c|c|}
\hline Crop & Nitrogen & Phosphorus & Potassium \\
\hline Corn............. & 100 & 30 & $8_{3}$ \\
\hline Wheat ......... & 40 & 12 & 23 \\
\hline Oats ........... & 41 & I5 & 47 \\
\hline Barley........... & 59 & 20 & 66 \\
\hline
\end{tabular}

These two tables show notable variations in food elements, utilized by different plants. Our comparison, in this instance, is of cereals, only; when the range of observation includes, not only cereals but also legumes, fiber crops, the errasses, and root and regetable crops, as well, the differences are peculiarly striking and marked.

Feeding demands of crops. - The question naturally arises: Is it likely that continuous cropping will exhaust 
the land? And then, again, another question: Is the potential plant food in sufficient store in the soil to meet all plant demands on it? W'e have discussed, already, the forms of plant food, and we shall not, at this time, consider the many ways open to us for rendering these forms available.

Let us, however, just as nearly as we are able, deter-

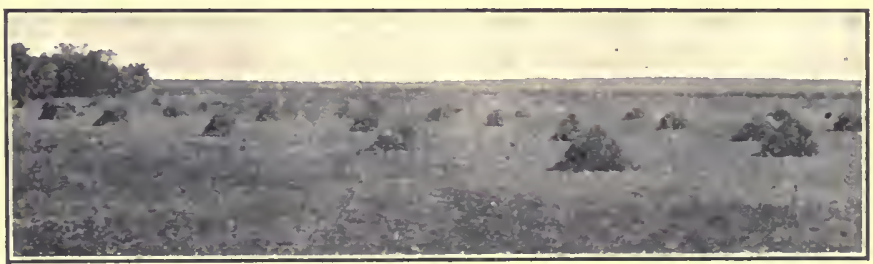

A CROP THAT GETS NITROGEN FROM THE AIR

mine the quantities of food demanded of the soil by some continuous system of farming.

For the purpose of illustration, let us assume that a young man at the age of $2 \mathrm{I}$ years secures a farm which he is to manage during his life-for 50 years, we will say. He plans a system of plant rotation as follows: (I) corn, (2) wheat, (3) clover, (4) clover and timothy, and (5) timothy: a five-year cycle. During the 50 years each crop will be removed Io times. Our problem is this: In case each of these crops is removed ro times and nothing returned to the land, how many pounds of nitrogen, phosphorus and potassium will be demanded of the soil, provided the yields are: corn 50 bushels, wheat 25 bushels, clover 2 tons, clover and timothy $I \frac{1}{2}$ tons, and timothy I ton during each five-year cycle?

On the bases of average composition we get the following: 


\begin{tabular}{|c|c|c|c|c|}
\hline & & Nitrogen & Phosphorus & Potassium \\
\hline Corn $\ldots \ldots \ldots \ldots$ & 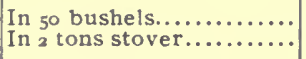 & $\begin{array}{l}40.9 \\
41.6\end{array}$ & $\begin{array}{l}x 9.6 \\
\mathbf{1 1 . 6}\end{array}$ & $\begin{array}{l}1 x .2 \\
56.0\end{array}$ \\
\hline Wheat......... & 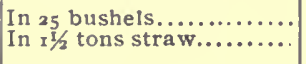 & $\begin{array}{l}35.4 \\
17.7\end{array}$ & $\begin{array}{r}11.8 \\
3.6\end{array}$ & $\begin{array}{r}7.5 \\
\times 5 \cdot 3\end{array}$ \\
\hline Clover .......... & In 2 tons $\ldots \ldots \ldots \ldots \ldots$ & $82.8^{\circ}$ & 15.2 & 88.0 \\
\hline $\begin{array}{l}\text { Clover and } \\
\text { Timothy }\end{array}$ & $\begin{array}{l}\text { In } 3 / 4 \text { ton clover } \ldots . . . \ldots . . . \\
\text { In } 3 / 4 \text { ton timothy......... }\end{array}$ & $\begin{array}{l}40.1 \\
18.9\end{array}$ & $\begin{array}{l}5 \cdot 7 \\
8.0\end{array}$ & $\begin{array}{l}33.0 \\
13.5\end{array}$ \\
\hline Timothy .... & In $x$ ton timothy $\ldots \ldots \ldots$ & $25 \cdot 2$ & 10.6 & 18.0 \\
\hline \multicolumn{2}{|c|}{ Totals for each cycle................. } & 302.6 & 86.1 & 242.5 \\
\hline
\end{tabular}

This table shows the total quantities of three plant-food ingredients secured by plants from the soil during each cycle period. Since Io of these periods are included in the entire period of 50 years, there are removed 3,026 pounds of nitrogen, 86I pounds of phosphorus, and 2,425 pounds of potassium: in the aggregate a large quantity. The next questions arising now are: Can the soil support this draft on it? Does the soil hold in store enough plant food to fill these demands?

To answer these two questions, we will consult the soil itself. For the purpose, we will call for evidence 25 soils that produce on an average the yields suggested in this study -50 bushels of corn, 25 bushels of wheat, and $4 \frac{1}{2}$ tons of clover and timothy (in three years). IVe will get these soils from different sections of the country: from the South, North, East and West, from the cotton belt, the hay belt, and the corn belt, from the arid lands. the semi-arid and the humid regions; in short, we will take typical lands of the country.

The quantities of plant-food ingredients-nitrogen, phosphorus and potassium-found in the fine particles of each acre in the surface foot are as follows: Nitrogen, 
6,984 pounds ; phosphorus, 2,824 pounds ; and potassium, I 2,460 pounds.

When these amounts are considered in connection with the requirements of the four crops-corn, wheat, clover and timothy-for the fifty-year period, we get the supply value of each ingredient.

By simple calculation:

Nitrogen will last 2.30 fifty-year periods, or I 5 years.

Phosphorus will last 3.28 fifty-year periods, or 164 years.

Potassium will last 5.12 fifty-year periods, or 256 years.

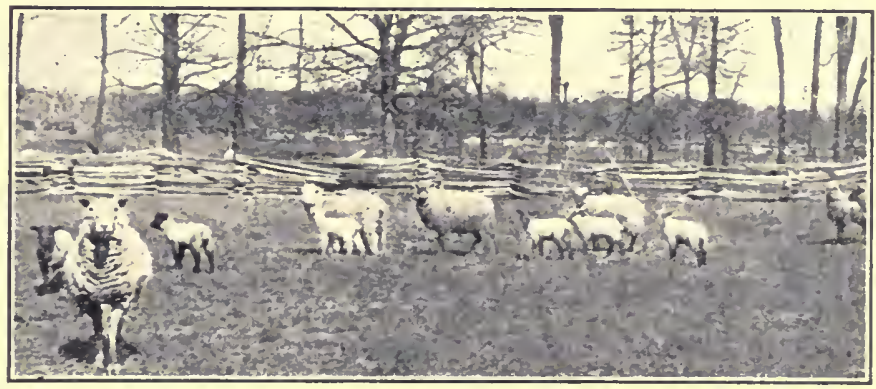

A SURE WAY TO IMPROVE THE SOIL

Four important factors to take into account.-But there are four other factors that enter into this furnishingsupply consideration besides the supposedly-available stores. These factors are:

I. The constant contribution to the available store from previously unavailable material.

2. The return to the land of straw, stover and other manurial refuse.

3. The increase of the nitrogen supply through the legumes.

4. The help that comes from the subsoil. 
The contribution to the store of available ingredients.-Nature is at work, constantly, changing the unavailable stores of plant-food ingredients into available forms: every sort of soil maker is at work. Hence, we may conclude that the crops (included in our rotation) have not only for use the supply that was available at the beginning, but they have, also, an additional supply that is being contributed constantly by the soil-making agents.

It is not unreasonable, then, to suppose, that when wise farming is done, manure added to the land, thorough tillage performed and a good tilth maintained, this contribution to the store of available food ingredients will keep pace with the outgo through the crops removed.

In this connection attention should be called to the fact that soils are running out rapidly under the present system, due to loss of available food by constant removal of crops, and to the loss of humus, and the consequent injury to physical condition.

The return of ingredients to the land.-There is seldom observed a system of soil cropping that removes the entire crop growth away from the land: always some part of the crop is returned to the soil, from where it originally came. With cotton, leaves, stalks, and often the seed find their way back; with corn, the entire stalk or else the main stem, with the leaves, in the resulting manure; with wheat, always the stublle and often the straw; and so with the most of our crops: some parts of them go back to the soil. In this way, the annual removal of plant food is lessened and a complete exhaustion is, in every way, quite out of the question.

The increase of nitrogen due to the legumes.-In the cycle discussed previously, during the entire term, clover occupies the land, more or less, for twenty years. Considered in connection with this discussion, it is clearly evi- 
dent that the nitrogen supply, instead of being seriously disturbed, more likely is preserved and it may not be out of the range of possibilities to suppose that the normal average is ever increased: a feature quite opposite in effect to that of depletion. Certainly, land occupied by clover twofifths of the time during a fifty-year period preserves its producing power. Who will say it does not even increase it?

The help that comes from the subsoil.- Since roots have come into the range of observation and study, we know that they seek deeper pastures than the surface foot allows. Roots go to a depth of two, three, four and often

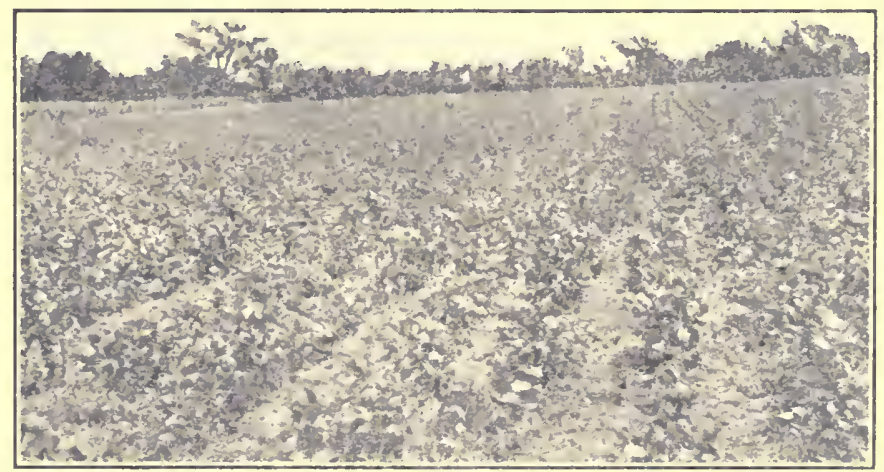

INCREASING THE NITROGEN WITH LEGUMES

A crop of soy beans that are bringing nitrogen into the soil and at the same time producing a high protein feed

ten or twelve feet. Consequently, the supplies that come to plants are not solely from the surface foot: for plants get food wherever their roots go, wherever the root hairs find mellow earth into which they may search.

'This subsoil contribution, therefore, is a large one, and one that, in a great measure, influences the potential supply of plant food, commonly supposed belonging to the surface soil, but which is a not-inconsiderable factor of the entire food-furnishing possibilities of the land. 
Potential plant food is large.-We may be certain, therefore, that the potential supply of food is large, that the stores of available plant food are more or less constantly reenforced from other sources and that, this being the case, the following conclusions are correct:

I. Soils are able to produce crops indefinitely with proper treatment.

2. Soils are never exhausted of their potential plant food.

3. Soils are often depleted in producing power, but only temporarily.

4. Worn-out soils are not exhausted chemically but physically. Their humus has been used up.

5. Soils, once productive, but now unproductive, may be restored to their former state through the rejuvenation of the physical life.

6. Physical improvement is the first step necessary for restoring the producing power of soils.

7. A fertile soil, wisely managed, maintains its fertility.

8. A fertile soil, unwisely managed. loses its fertilityproducing power-but not its chemical constituents: these are present in the tightly secured storehouses of the land.

9. Crop production bears a close relation to the physical nature of the soil-the humus content, the texture, the air and water circulation, the nature of the earthy material, the previous treatment given it; but no correct estimate can be made from the chemical analysis of the soil alone.

Io. Chemical analysis can be interpreted only in connection with group or type surveys, reënforced by loroad observations in the field, and modified by climatic conditions, commercial opportunities, and the temperament of the operator. 


\section{CHAPTER X}

\section{THE RÔLE THAT TILLAGE PLAYS}

Just when man began the improvement of soils by means of tillage tools we do not know, nor do we know the kind of tools that were first employed.

This, however, we know: the first written evidence of civilization includes in its work simple tillage operations that the fruits of the field might be increased. The first simple tool may have been a shell from the sea, or a pointed stone from the mountain side, or it may have been a sharpened stick; it matters not, for in time these and other kinds were succeeded by the crooked stick, fastened to the horn of a bull, perhaps, which in time became modified, and developed into the modern tools of tillage.

Nature tills the land.-While we often think Nature neither tills nor cultivates her fields, we forget that every force she has at work is actually performing just these very things. For what are the freezing and the thawing-the heaving of the surface-but tillage operations; what are the crumbling and tearing and breaking by air and water but simple forms of tillage; what are the channels, made by earthworms and other animals that burrow in the earth, but plowing of another order; what are the deposits of silt, left from overflowing waters, but new earth, ready for newly laid seeds, as rich and effective as that turned by plow or any cultivating tool; what are the roots that work their way deep into the soil but vegetable tools of tillage; what are these-one and all of them-but plows and harrows and hoes, which Nature uses for preparing the land for new seeds, for new crops? 


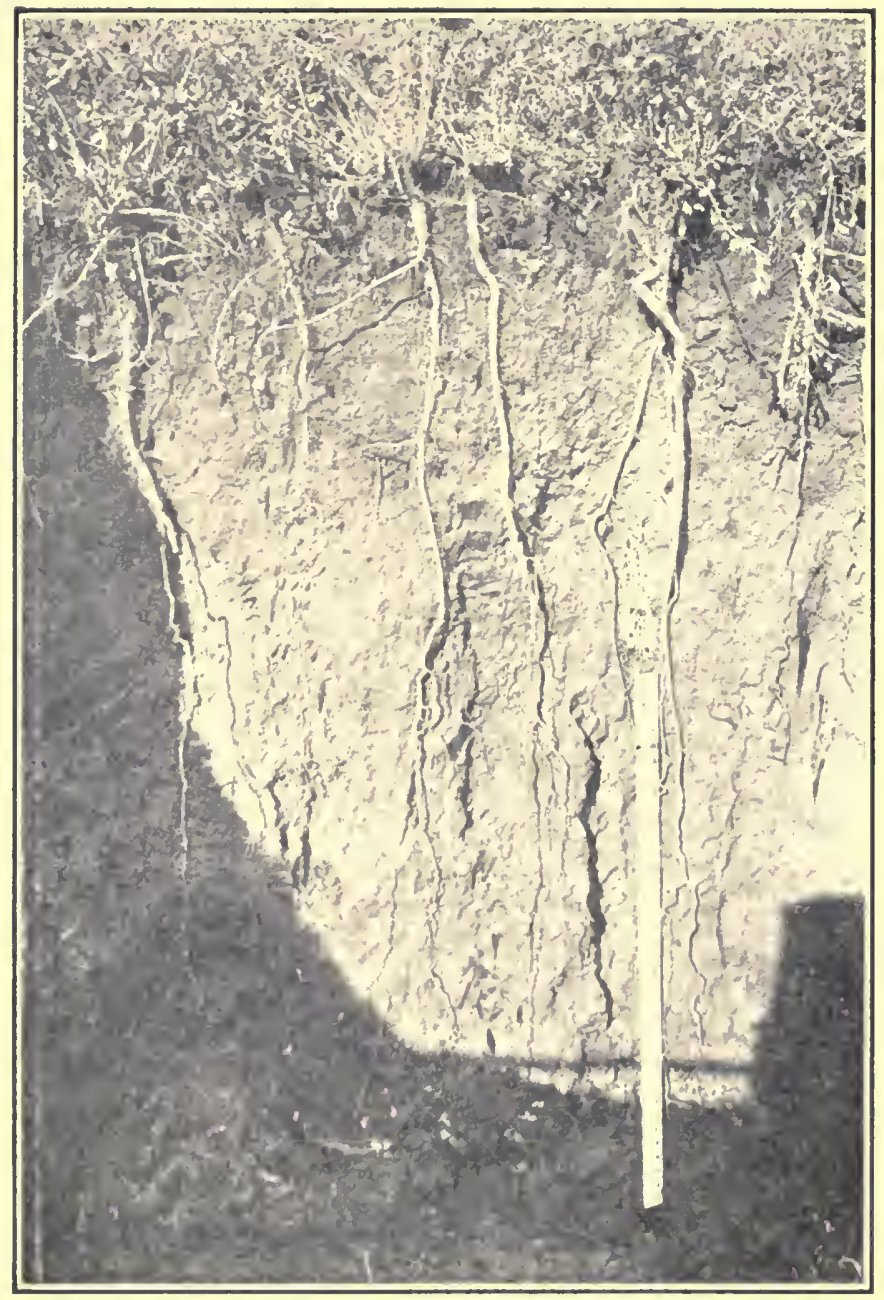

ALFALFA RIOTS-VEIFTABI.E TILLAGE TOOLS

A wonderful soil-maker at work. See how deeply the roots godown in the soil 
Nature Works Slowly.-Of course, Nature's tools are not meant for fast-working man: too much, now, is required of the producing power of lands for modern men to depend upon these ancient, these earliest forms of tillage. Nor are meant for our use to-day the ancient forms designed by the early man: the crooked stick has been displaced; the wooden plow and the wooden harrow have disappeared; so, also, all ancient, out-of-date tools and implements for every purpose have been replaced by kinds more suited to the needs and the demands of present-day requirements.

Tillage not a modern practice.-Nor must we for a moment believe that tillage is a modern discovery. For it is not: it is as old as the practice of putting seed into the soil by cunning animal or man. It is a part of every civilization: of the ancient Chinese, of the Egyptians, of the Greeks, of the Romans, of the Britons; it is older than history, even older than civilization.

Jethro Tull the father of modern tillage.-The first impetus given modern tillage that has not yet abated had its origin with Jethro Tull, who set forth in I733, in his book "New Horse-Hoeing Husbandry," his ideas regarding the value of simple tillage for the purpose of fining the land. His entire philosophy was built on these premises: that plants secure food through absorption of the fine earthy particles; that as the numbers of these are increased in the soil, so is increased its productivity; and, consequently, that the maximum growth of plants will result when the earth has been made fine. Neither the wise farmer nor the critical scientist can find fault with this system of tillage, for it is the basis of all good farming to-day. The fault is not with the system, but with the explanation, for plants do not absorb by means of their roots the fine particles of earth, as Tull and his 
disciples believed. On the other hand, they do this: they use only soluble substances such as are dissolved by the water of the soil, and not the components that contain the elements of food, but the elements that are dissolved out of the earthy constituents. Hence, stirring the land by tillage is helpful only in increasing the available food

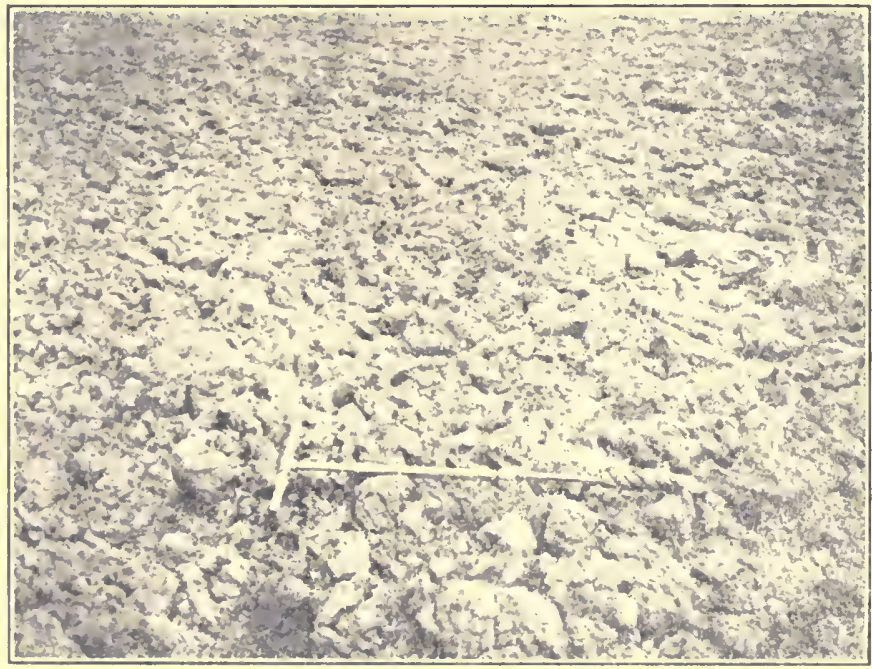

A GOOD JOB OF PLOWING

It is a good plan to use the harrow while the soil is still fresh and moist-just after plowing. Then less eftort will be necessary in preparmg the seed bed

by allowing soil water and air freer access throughout the soil so that they may more easily and more readily do their work.

Now, these things being true, no particle, no matter how small it may be, ever enters into the roots of plants. Ilence, tillage is not a lirect source of plant foot: it is not additional nutriment: it is, on the other hand, the 
stimulant that induces plant food to seek solubility rather than to remain concealed with the components that are useless as nutriment for plants.

The rôle that tillage plays.-Every one who tills the land, knows that tillage favors the act and increases the productivity of soils. The proof of this is furnished wherever thorough work with the plow and harrow are done; wherever the soil is opened or stirred by any tool of any sort; wherever the soil is loosened or fined, or mellowed, by means of any description the soil will yield forth its fat in the crops produced thereby.

Tillage does its work in many ways, the important ones being:

I. The increase of available plant food.

2. The beneficial effects that result in a mechanical way.

3. The assistance rendered chemical changes.

4. The increase of the water-absorbing and retaining content of the soil.

5. The destruction of weeds through tillage.

Available plant food is increased.-Since large stores of potential plant food exist in the soil, they should be called into active use; and they may be so called, if effort is directed in the right way, that the qualities making them unattractive to plant roots may be eliminated. Only soluble food finds favor with plants; they reject all other sorts. It is the role of tillage to secure soluble plant food, to put hitherto insoluble substances into available forms, to insure stability in the food stores, and, even to increase, the normal supply.

Beneficial mechanical effects.-The soil is the real home of the plant; there the roots grow and gather food. Any agency that renders this home more attractive and comfortable, that increases the ease with which roots 
may gather their substances, that opens the lower depths for less laborious descent, that enlarges the pasture grounds for feeding roots, favors plant growth and induces larger crops on the land so treated.

Soils that are hard, compact and lifeless, through tillage, may be opened, mellowed and restored to life. Any

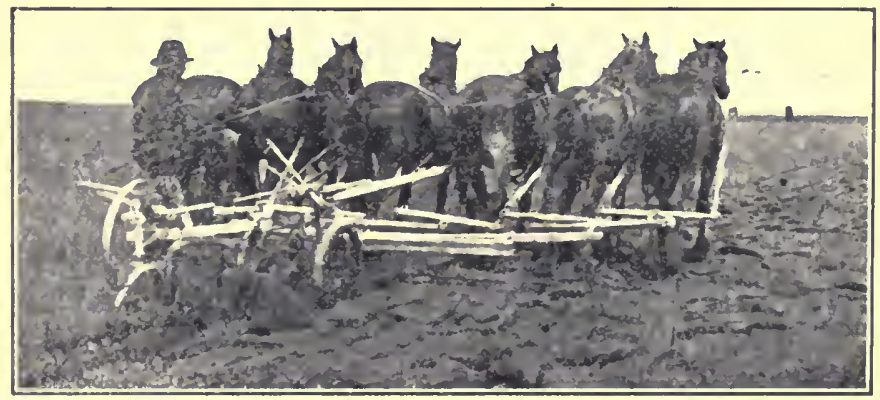

PLOWED FOR THE FIRST TIME

The plow enlarges the pasture grounds for feeding-roots

system of tillage that loosens and lightens such soils, improves their texture. And poor texture means poor, uninviting, uncomfortable homes, in which few, if any, plants can prosper. Good tillage offers much available food, warm, comfortable homes, inviting living environments, and pleasant quarters in which tiny roots may live.

When soils, by nature, are loose and open, they may be benefited by tillage tools that firm and compact the surface soil. Thus, often the roller is lesirable for just this purpose: to press the particles towether that the interspaces may be lessened and the particles, themselves, compacted therely. This practice induces capillarity, 
and secures a freer movement of soil water from the lower regions to the surface layer above.

The assistance rendered chemical changes.-The ways through which tillage increases the amount of available plant food elements are:

I. The effect on place and movement of soil particles.

2. The entrance of the silent soil makers-air, water, etc.

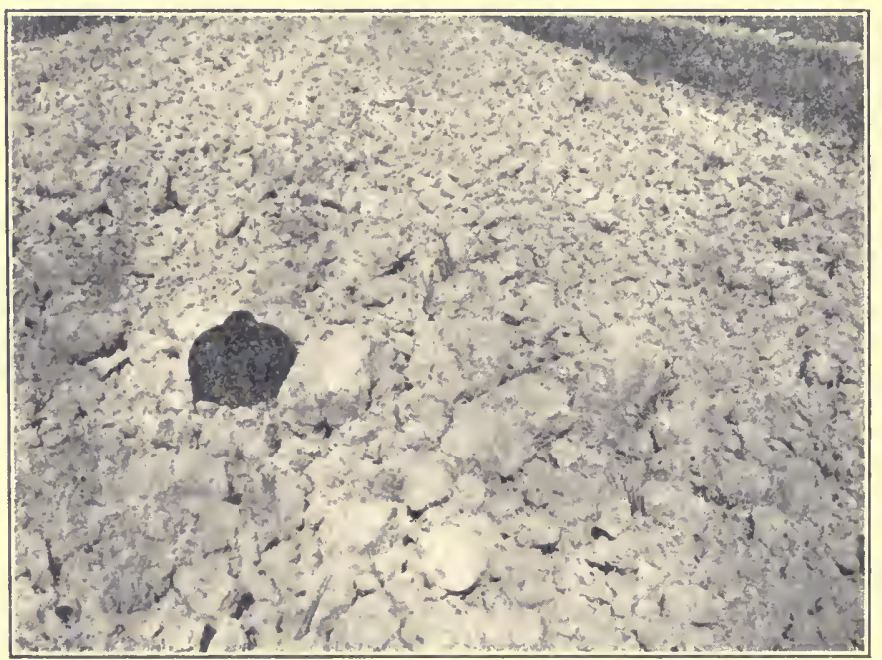

EFFECT OF PLOWING WET LAND

This is ordinarily an easily cultivated field. It is now ruined for some time to come

3. The mixing of humus and other soil components.

4. The freer movement of salts and gases.

5. The influence of tillage on microscopic life.

When soil particles are moved from the place they have occupied for some time, and brought into contact with 
other particles of a different nature, chemical changes are provoked through the interchanges of the chemical elements of the many soil compounds. The interchange of acids and gases always is taking place in the soil, but it is most active when a disarrangement of soil particles has occurred.

Since oxygen is such an active element, combining freely with elements in all sorts of substances, it follows that when air is allowed entrance-and tillage allowed to rule-chemical action and change most actively takes place.

A sure way to injure the soil is to saturate it with water or by tramping to exclude the air: you lessen the activity of the chemical agents: you retard the making of plant food available.

Whenever humus decays in the soil, the adjoining particles are affected, and, in a measure, at least, decay or rot. These break into simple compounds: they come nearer to the nature of plant food. Hence, when you incorporate humus in the soil, you add a plant food matrial to the soil and supply, at the same time, a forcefullyworking agent that makes available stubborn food constituents.

Tillage permits better diffusion of salts and gases, and other changes closely allied thereto, and influences favorably the decomposition of earth and earthy materials.

The microscopic life of the soil is influenced to a marked clegree by tillage and its resulting effect upon the chemical nature of the soil. In connection with the nitrogen element we have the denitrifying bacteria which liberate nitrogen into the air, and the nitrifying bacteria that change nitrogen compounds of the soil into nitrates, the form that plants use most eagerly. The first kind is influenced by tillage in this manner: wherever poor acra- 
tion prevails, the denitrifying bacteria are most abundant and active; hence, there is a constant loss of nitrogen from the soil-something certainly most undesirable.

Poor tillage, bad aeration, and improper physical treatment are favorable to the denitrifying bacteria but unfavorable to the nitrifying bacteria.

Good tillage retards the action of the harmful bacteria and at the same time accelerates the working of the beneficial ones-a most important reason why tillage never should be neglected.

The increase of the water-holding content of the soil.Tillage assists soils in securing and in holding water in the following ways: By opening the surface crust so that water may enter the soil more freely, and by hastening percolation that the subsoil may receive more water.

When the surface crust has been opened by tillage tools, water finds lodgment until it gradually sinks into the soil,-a most excellent way of preserving what might be lost otherwise. Tight-bound soils, with unbroken surfaces, secure no great amount of water, often not enough for its many needs. Soils, like the stiff clays, are enabled to secure much more water and to hold it also, if subsoiled and fall-plowed. Indeerl, this is a splendid treatment to give such lands. although subsoiling is quite costly.

Of course, tight-bound soils that have little air space in them, and whose particles are closely pressed together, permit slow descent only to all water passing downward. This is a condition certainly not clesirable, and may be remedied and improved in this respect by deep-stirring agencies that open and stir and mellow at depths not reached by ordinary surface tillage. Our leguminous plants are wonderful helpers in this difficulty.

It is also important to have the soil mellow and fine, thereby increasing both the number of particles in the 
soil and amount of spaces between these particles. When these things are done, water more freely enters and more of it is retained than otherwise would be the case were these conditions not to be had.

Tillage gets rid of weeds.-Good farming can never be of high quality if weeds are allowed to have their way; and they certainly have their way whenever tillage is neglected or whenever plows and harrows and cultivating tools are not constantly and consistently used.

Why are weeds a menace to farming? For these reasons: They steal from the soil food that should be kept and preserved for cultivated plants; they rob the soil of its water, that should be held for useful plants; they crowd growing plants to their hurt (improved plants are less hardy than weeds, for the latter have inherited the ability to shift for themselves); they shade the land, which works injury to many varieties which need all the warmth and sunshine they can get. For these reasons, weeds are a menace to cultivated crops and for these reasons they should be driven from the land.

Since food and irink are objects of constant thought and solicitude and require you to labor day in and day out so to treat the soil that both may be amply provided, why should weeds be spared: why consider them in any other light than enemies of the disagrecable and hateful sort?

Here is an examp!e: A ficld plante 1 to conn was divicled into two sections: on one section, after the second week, weeds were allowed to grow, to contest with the corn for supremacy: from the first section 82 bushels of shelled corn for each acre were harvested, and from the second section 17 bushels. The difference represented the hurtful effects of the weerl plants that grew in the corn.

Here are just a few thoughts to remember: 
Stir the soil thoughtfully and continually, and it gathers in the rains to make abundant growth of plants when summer's heat and drought are come; plow the land earnestly, and it gives its fat with gladness and with bounty; open the bosom of the soil with the plowshare, and health comes to the land and wealth to the operator; spare cultivated fields the disgrace of ravaging weeds, and golden grain and bountiful harvests come as rewards; fine and mellow the earth, and luxuriant vegetation gladdens the heart and rests the eye; till and always till with skillful hand and eye, and Nature deeds her gifts-success and prosperity and joy. 


\section{CHAPTER XI}

\section{LIMING THE LAND: A CORRECTIVE FOR ACIDITY}

The use of lime in agriculture, especially its use as a soil improver, was known in days of long ago: when Rome was young, and Greece was struggling for the supremacy of the world. For Hesiod, the Greek, mentions its use in his writings, and Cato and Pliny, keen Roman observers, frequently discussed its importance in securing the productiveness of the soil. In America, this same observation has not been wanting. For more than a century in time, lime, as a soil improver, has been advocated by successful farmers and planters, who, realizing its value in the early agriculture of the country, gave it effectual and constant trial, to their satisfaction and profit.

The kinds of agricultural lime.-The real source of lime is in rock formation: out of these formations agricultural limes are obtained. The following forms are common: limestone rock, niagnesia limestone, gypsum or land plaster, marl, and oyster-shells.

Ordinary limestone contains about fifty per cent. lime, the remaining substances being carbonic acid, silicon, iron, magnesium, and aluminum. When burned, the product resulting and known as lime is nearly pure, and weighs about ninety pounds to the bushel. When water slaked, this amount increases to three times the original weight.

Magnesia limestones vary in composition, the best of them containing about eighty per cent. of lime. Magnesia lime may be substituted for ordinary lime as a 
corrective agent for acidity, but it should not be used repeatedly on the same land.

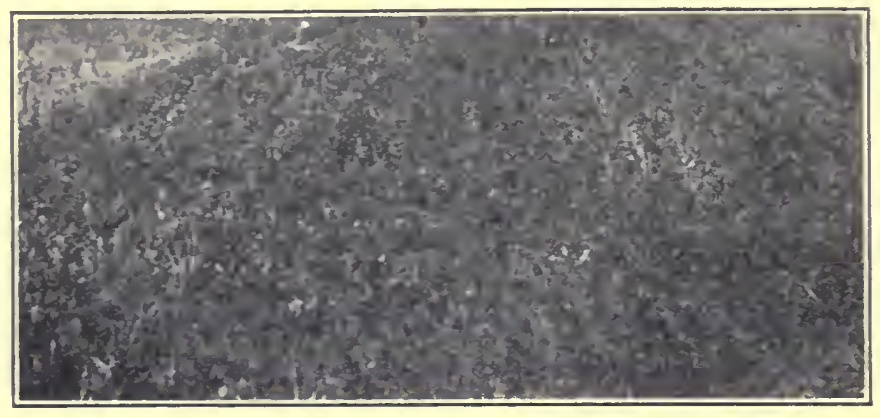

LIMED

Note the dense, vigorous growth of clover, almost completely biding the wheat stubble

Gypsum is found in large deposits, and is rock-like in form. For commercial purposes, after being mined, it is

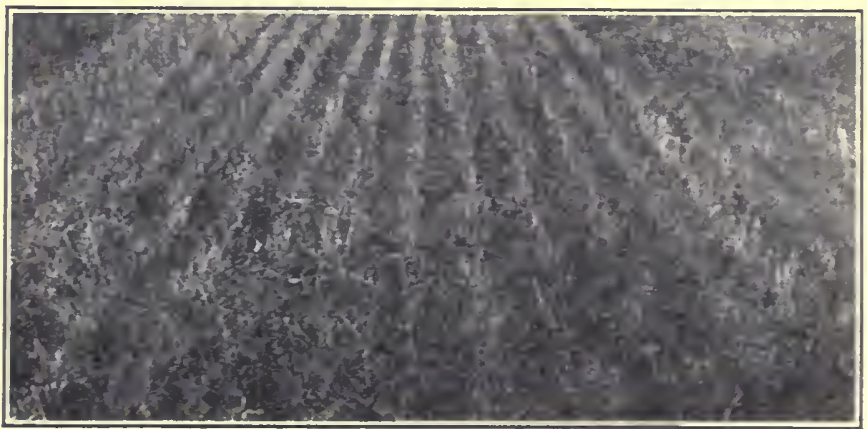

UNLIMED

The stubbles were not hid by the clover at the end of the season

ground into a fine powder, a form in which it is best fitted for use. Although gypsum contains about thirty 
per cent. of lime, you should not substitute it for ordinary lime for correcting acidity in soils. Its effect is rather stimulative, aiding in setting free other plant foods, notably potash.

Lime is found, also, in earthy shell deposits-known as marls. These occur only in lake and ocean regions, and for this reason they are little used outside of the immediate locality in which they are found. In composition, marls vary greatly: from Io to 50 per cent. of lime being available.

Oyster shells, also, are lime makers. They contain about ninety per cent. of lime, which, when burned, is comparatively pure. Gas lime, now sold extensively as an agricultural lime, occurs in this way: quick lime is used in gas works for the sole purpose of taking from the gas its many impurities. When saturated, and hence no longer useful, it is sent away under the name of gas lime, to be used as a fertilizer for soils. Gas lime contains, on an average of about forty per cent. of lime. Since gas lime is often poisonous, it is not desirable for the land.

What lime does in the soil.-When applied to land, lime acts in these ways: it induces chemical activity. causes physical change, usually favorably, and supplies a plant food element-calcium. In reference to the last, let this be said: little evidence points to any conclusion that lime is lacking in most soils to such an extent that any additional supply is needed for food requirements. While it is true that some investigators have been led to believe the reverse of this, still their contention is far from being proved, and, until fully demonstrated, we shall look for the explanation of its beneficial qualities as being in the direction of the chemical and the physical changes that take place, occasioned by its presence in the soil.

How lime acts chemically.-First in importance are its 
decomposing effects on the mineral substances of the soil. It has been shown by experiment that lime decomposes certain compounds in the soil, thereby releasing stored plant food. This is especially true of potassium compounds secured in the soil silicates. When lime is added to the soil, these silicates are decomposed and the potassium therein is renclered available-plant roots are served what heretofore has been denied. You should bear in mind, however, that lime has no power for supplying potassium: it renders available only such material as already is present in the soil.

Lime works in harmony with the phosphorus compounds of the soil, also. It does so in this manner: Soluble phosphorus combines freely with other elementsiron and aluminum, for instance. But these are undesirable compounds for the reason that they are insoluble, and consequently plants reject them as food. Lime, on the other hand, attracts the soluble phosphorus more energetically than does iron or aluminum, and so helps the plant because the plant fancies the products that lime and phosphorus together make. Now, this is a good reason why lime should be given freely to the soil.

Yol1 will find, also, that lime is an extremely valuable agent in helping the decomposition of organic matter in the soil. While organic matter is useful and a necessary component of every good soil, still we must not forget that much valuable plant food is stored in this organic matter, and that a part of it, at least, should be turned over to plants each year, its replacement to take place subsequently by other and additional donations. Much of the nitrogen content of the soil is obtained through this destruction of organic matter. Hence, it is well to keep this supply in mind.

Lime promotes good texture.-With old soils, espe- 
cially, perhaps because the humus has been destroyed, the soil texture is bad; plowing is done with difficulty; overturned earth is hard, lifeless, and inactive; air and water are treated with indifference. The consequence is: poor crops are produced. When lime is supplied these soils in sufficient quantities, what a wonderful change takes place! At once the soils mellow: they lose their gruffness, their sourness, their bad behavior: they show greater vigor, life becomes apparent again, plants are attracted, and more: air and water are differently received, their wholesome influence appreciated, and their offer of service accepted.

Lime influences soil particles.-Just as soon as lime is supplied the soil, a change takes place in the position of soil particles: they "flocculate": they gather together in little balls. Now, this is just what is needed in order to make these tiny particles behave in such a manner that air and water will be so attracted that both will be willing to move freely about in the soil, to the advantage of the soil itsclf, and to the advantage of plant roots that are living there.

When a condition like this is secured, extremes of dry or wet weather will influence the soil in a much less degree than otherwise would be the case. were it soilbound, inactive, and lifeless. It is stated that one part of lime is able to flocculate and clear io.ono parts of mudly water. You can understand readily the effectiveness of an entire ton of lime in the average soil which weighs in its surface six inches but goo tons per acre.

Lime is a corrective for acidity.-One of the most wholesome influences that lime brings to the soil is its sweetening effect: its driving away of sourness-the acid condition of the soil. When decomposition is taking place in the soil, acid substances are formed and so remain. 
unless they are able to combine with other substances that eliminate or render impotent this acid effect. We have a number of substances that can be used to correct this acidity, among which may be mentioned lime and wood ashes. Both of these substances are good, but lime is usually the cheapest, the most available and easiest to apply; hence, its use as a corrective for acidity is most often mentioned. Soils most likely to be found sour are: heavy clay soils, when poorly drained; soils abundantly supplied with organic matter; soils that have been poorly tilled, and consequently air-hungered; and soils deficient in humus but kept at work by mineral substances, like kainit, muriate of potash, and acid phosphate. When lime is applied to soils of such nature, its wholesome influence is manifest at once. In this connection the beneficial influence of lime on the availability of nitrogen is of interest. It has been shown by Wheeler at the Rhode Island Station that lime exerts a direct benefit to plant growth by overcoming soil acidity, and in doing so, increases the assimilability of the soil nitrogen. Hence, we have an improvement of the physical condition of the soil and also an increase in availability of plant nutrition.

How acidity may be detected.-Does your soil look sad and sickly? If so, it may need lime. Does your soil fail to produce vigorous growth and good color in the plants it grows? If so, it probably needs lime. Does your soil show acidity when tested? If so, it truly needs lime.

Suppose you try this method for detecting acidity: Get a penny's worth of blue litmus paper at the drug store. Dig from the field a handful of wet earth that looks suspicious; into this insert your knife blade, and in the opening put a strip of the blue litmus paper, and press the soil tightly about it. If sour, in a short time the paper, where in contact with the moist soil, will become reddish in 
color and you may know that your soil is sour and that lime is needed as a corrective for the acidity, for the reason that most of our plants do but poorly in acid soils.

How lime may be applied.-A common way that is practicable and inexpensive is to place from Io to 25 bushels of lime on an acre, in heaps of two or three

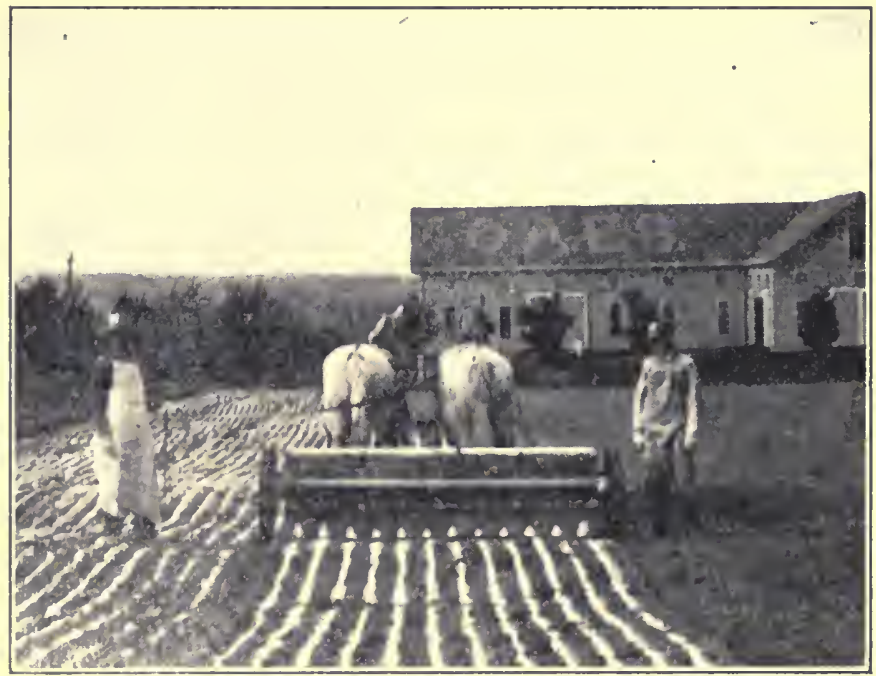

USING THE LIME SPREADER

As soon as the lime is applied it should be harrowed into the soil

bushels, covering with soil or old sacks until the lime falls apart and becomes thoroughly slaked. This done, you should spread evenly over the soil and harrow in.

A more satisfactory methol is to slake by means of water, and as som as in a puwlery state, apply to the land and at once incorporate with the soil, not by the plow, for that places it $t(x)$ leep in the soil, but by some surface-working harrow or cultivator. 
The lime-spreading machine now does very excellent work, and has been so improved that it will very likely supersede all other methods of applying lime to the soil. It has this point in its favor: the work can be done quickly; it can be done while lime is still in a fresh state and before it loses its active properties. And here is another fact you should remember: incorporate lime into the soil by means of a harrow as soon as applied. You will make a mistake if you wait for a rain, for it may be long in coming. Unless a very heavy rain falls, so as to carry the lime applied into the soil, you will likely lose much of its value, since it readily returns to its carbonate nature-its state before it was burned when locked in store.

How much lime to use? How frequently?-Sand soils are influenced most favorably by rather small applications of lime; say, from 200 to I,O00 pounds per acre of slaked lime and twice the quantity if either ground limestone or ashes are used. It is believed that slaked lime long exposed to the air is best for sand soils. Larger applications of lime may be given clay soils-from 400 to 2,000 pounds. For such soils, burned limestone and water-slaked lime are preferred, usually, before either ashes or ground limestone.

Lime may be applied every five or six years, using it before the crop in the rotation that is most helped by the application.

Lime is helpful to bacteria.-You will recall the frequent allusions that have been made to the bacterial life of the soil; to the presence of immense quantities of those microscopic plants that always are working for the improvement of soils; that plant food may be rendered available; that air nitrogen may be gathered in and secured for on-coming years; that the entire body of the 
soil may be bettered and improved. But do you know these useful kinds are active only when the soil is free of acid, or is neutral in its reaction? If this is true, then we cannot expect these good fairies of the soil to do their work, unless we do our part and get rid of this distasteful enemy. Our legumes-root tubercle plantsquickly disappear from any soil where an acid condition prevails.

Not many years ago we heard much about "clover sick" soils. We know more about these now: some were acid soils, and clover disliked them; root tubercles failed to develop because the bacteria were unable to thrive or even live in such soils; and, without bacteria, there could be no formation of the nodules, and without the nodules, there could be no vigorous growth of the clover plant. Just as soon as lime was used freely enough to correct the acid condition, bacteria returned to these lands and the clover plant prospered as it had done in former days, when the land was sweet and wholesome, and filled with an abundance of vegetable matter.

If it is your plan to employ leguminous crops in your system of farming, so that needed nitrogen may be secured fully and without cost to you, it will be to your profit and advantage to guard against an acid condition of your lands; for the tiny forms of plant life that multiply and grow and develop in the soilare the direct means of increasing the yields of the useful crops that grow out of it. 


\section{CHAPTER XII}

\section{THE QUEST OF NITROGEN}

With the closing of each decade, some new discovery has been given the world, some new thought has been launched that has borne its fruit e'er Time went far on his journey again. It has been so in science and it is so in agriculture.

Men are ever seekers after truth. Their quest has been for it throughout all time, and in every direction. As a result of this quest, philosophy is the better, art is the better, government is the better, science is the better, law is the better, and all men are the better.

The quest of truth has gone on from the very beginning of time; it has led out in every imaginable direction. But the surprise of many is this: the postponement of the pursuit of the practical until recent periods in human progress. Especially has this been true of the practical arts, and of agriculture. And yet all the while the world has been dependent upon the soil for its bread. for its raiment, for its shelter; and back of these is the controlling influence of the nitrogen of the soil.

The quest of nitrogen is of comparatively recent times; but once its story learned and its truth established, the solution of its mystery becomes a most valuable contribution to crop production and to soil maintenance, as well as a most powerful force in a new agriculture.

Farming in a broad way, now, is being built upon the legumes: the tiller of the soil is becoming a legume farmer. This state of affairs has resulted in recent years, only; in fact, since the publication in $\mathbf{1 8 8 6}$ of the 
researches of Hellriegel and Wilfarth, who set forth with a great array of facts the way in which nitrogen is accumulated and fixed in the soil. While there were investigators before this time who through study and research had got an inkling of the true secret, they could not find the key that unlocked it. Since the door was opened by these agricultural wealth-makers an abundance of evidence had accumulated, showing, without a shadow of doubt, the manner in which the stores of free nitrogen of the air are utilized in plant nutrition.

The free nitrogen of the air, you know, is not available plant food. No agricultural plant of itself can secure this air element for its use-not a wee bit of it. Of course, many men, and some very learned men, at that, believed in the early days just the opposite, but they have been proven in the wrong, and at last the true solution of this knotty problem has been found, and solved in a way of the highest value to every man who manages land and who employs the methods open to him, that his pooryielding fields may be restored to power, and their fertility and that of others fully maintained in respect to nitrogen.

The story of the secret's discovery.-To have the complete story of the fixation of nitrogen, we shall have to go back quite a good way in history; back to the time when chemistry first appeared as an exact science; back to the time when it was believed that all plant substances came from the soil: we shall have to go back to these days, in order to know the early theories of plant nutrition. Only the real guide-mark theories will be introduced, that the development of the iclea of nitrogen fixation in the soil and its use by plants may be clearly understood.

These important guide-mark theories are as follows:

I. That all plant-food elements come from the soil. 
2. That nitrogen is secured by plants through the absorption of soluble organic substances.

3. That nitrogen is due wholly to the atmosphere: the Liebig "mineral theory."

4. That neither legumes nor cereals are able to "fix" the nitrogen of the air.

5. That leguminous plants get their nitrogen from the atmosphere and others do not.

6. That the soil, aided by microscopic vegetation, gathers free nitrogen from the air.

7. That bacteria in the root nodules are responsible for the fixation of nitrogen and the transfer of it to the plant.

The first theory: All elements came from the soil.Until science was ready to devote itself, in a measure, at least, to some practical problem, like a study of soils, plants, or animals, progress could be slow only, and theory of little value save in a most indirect way. Until proof might be furnished, that should contain a grain of fact or evidence as we consider such to-day, suggestions would be of value, only, in that they occasionally worked in sympathy with the governing law, unknown in what manner or how, to the author, or to the disciple that followed and practiced his philosophy. Evidence in these cases were coincidences, only and of no further value.

The second theory: Plants absorb soluble organic substances.-The theory of absorption, in the light of knowledge on these subjects, had some reasonableness about it. This theory declared that only soluble organic substances were available as food for plants; that as such plants secured their food; that organic substances furnished not only the nitrogen but all other substances as well. And to a certain extent these ideas were correct. The fault of this theory lay in its incompleteness. For the mineral supply of food was quite overlooked: only 
soluble organic matter influenced crops' growth. This view was held by some investigators-De Saussure particularly advocating it. It was overthrown, however, when Liebig proposed his mineral theory.

Liebig's theory: so-called "mineral theory."-The author of this theory was the real beginner in chemistry, as applied to things agricultural. He worked with soils; he studied many agricultural plants; he devoted a great part of his useful life to many problems of plant nutrition. His theory held that only the ash or mineral substance used by plants is obtained from the soil; that the carbon, as well as the nitrogen, is secured by the plant from the atmosphere-the great storehouse of these materials. Licbig contended that when mineral substances are abundant, either through nature or through other supply, maximum yields will result, other things being provided, regardless of the quantity of potential nitrogen in the soil. He further claimed that if an abundance of the necessary minerals is present, the plant will be well able to take care of itself, and by its own efforts secure just as much nitrogen as is required from the nitrogen compounds of the air that are washed down in rain, snow and hail, as is required for every need of the plant. For did not the leguminous plants show this? He thought so. If the cereals failed to do likewise in soils apparently no worse, it was solely because minerals were present insufficiently to supply the plant with its requirements; and, because of this fact, these cereal plants were rendered somewhat impotent in their ability to get what nitrogen they needed. This mineral theory simply meant this: put minerals into the soil, and the plant will be strong and vigorous, and (quite able to secure its nitrogen, irrespective of the supply of the soil.

The theory of non-fixation: no plants "fix" atmospheric 
nitrogen.-Boussingault already had shown, even before Liebig had formulated and promulgated his mineral theory, that there were considerable differences between yields of certain groups of plants, and especially that there were noticeable differences in the nitrogen obtained, when cereals and leguminous crops were grown. He had ascertained, also, that when leguminous crops were introduced, either before or after cereals in any plan of rotation, a greater quantity of nitrogen was secured during the growth of the leguminous crop than during the growth of any cereal crop, and this was the case when additional manure was supplied.

Liebig was led at this time to revise the theory he had maintained heretofore, by declaring that cereals of all kinds must secure their nitrogen from the soils or from some supplied fertilizer containing this element.

At this stage of investigation other workers came into the field, notable among whom were Lawes and Gilbert in England. These men carried on experiments quite similar in nature to those of Boussingault, and which seemed to show that the only source of nitrogen supply is from the soil; in other words, that no cultivated plant is able either to secure free nitrogen of the air, or to establish it in the soil for future use. It is able to secure it only as it does mineral elements: from the compounds of the soil, or from fertilizing compounds supplied with the soil.

The theory of differences: legumes not like cereals and others.-While the theory of non-fixation of atmospheric nitrogen by any kind of plant generally prevailed (until the true solution was given by Hellriegel and Wilfarth), still there were some among the workers who were not satisfied; and it is to their agitation and to their unwillingness to accept the interpretations of the results that all former theories were proved incorrect and the truth of 
the matter finally was given the world. These men were wide observers: they included the field, as well as the laboratory, the fertile soil and the infertile soil, summer crops and winter crops; they sought the truth, and would not be comforted so long as a single doubt remained. For did not every field trial show that the legume produced

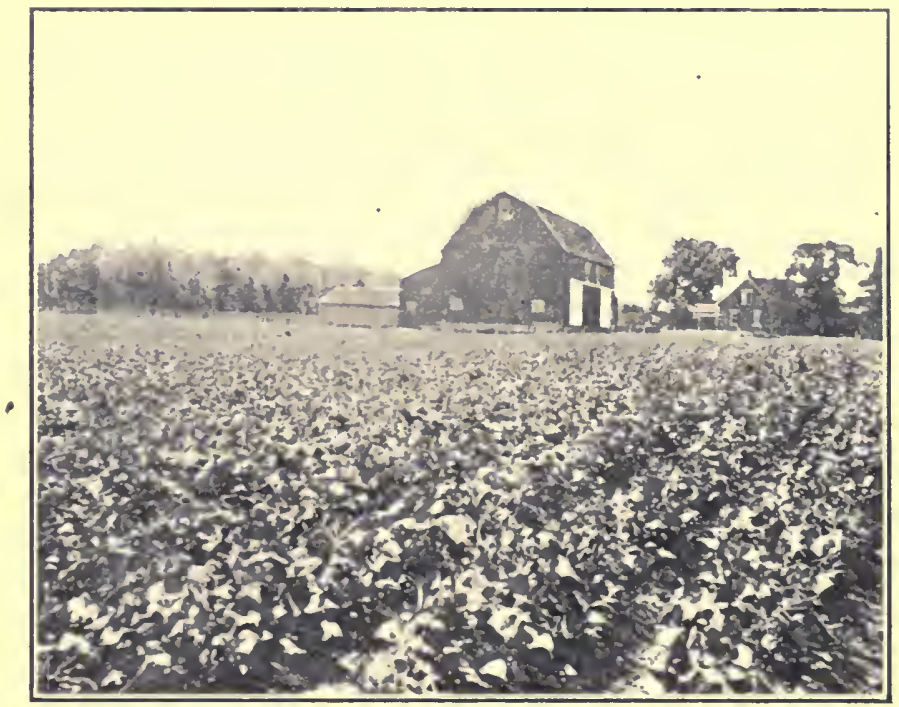

A MAGNIFICENT CROP OF BEANS

Legumes subsoil the land, contribute to the humus stores and add nitrogen to the soil

abundantly, although in these same soils the cereal produced indifferently? IV as it not true that in every case where a legume occupied the land for a few years, when succeeded by a cereal, a marked increase was apparent over similar soil. unocupied previously by some crop not a legume? So spoke loelcher with conviction: the 
atmosphere furnished nitrogen to the clover plant. So spoke Ville: the free nitrogen of the atmosphere becomes food for clover and for some other plants.

But the difference was not explained, for at that time it could not be explained. The time was still unripe.

Enter the microscopic plant: soil assistants in nitrogengetting.-Now comes Berthelot, a French investigator, with the theory that in the soil there are great numbers of microscopic plants, living in the soil and belonging to the soil, in fact, being a part of the soil itself; that these are useful and valuable plants, small though they may be; and that these tiny plants do this thing: they help the soil secure atmospheric nitrogen, and help it in such a way that all plants growing therein get the good of it. And Berthelot was right so far as he went, for he started in the direction in which the true explanation was later found.

The concluding theory: the secret of the root tubercle: This entire mystery was cleared at last by Hellriegel and Wilfarth, who found, by their investigations, that certain plants, like cereals and grasses, within limits, grow in proportion to the amount of plant food supplied-including nitrogen. If an abundance of mineral elements and nitrogen was supplied the soil, there was secured always a most bountiful harvest; if, on the other hand, nitrogen, for instance, was withheld, a feeble growth, only, resulted, if, indeed, a lingering death did not actually take place.

With the legumes-clover, lupines, peas, beans, etc.-a difierent behavior was observed. Instead of dying, when the nitrogen content was consumed, these plants recovered, very rapidly, indeed, and until maturity, maintained a most luxurious growth. And this condition prevailed despite the fact that no nitrogen compound of any sort 
was given the plants or added to the soil, either before planting or during any stage of growth.

These observers noticed a peculiarity-the key of the secret-that others, also, doubtless, had observed, but who failed to connect the same to the theory of plant feeding and plant growth. The peculiarity which they included in their studies was the characteristic growths or nodules that persistently associated themselves with the roots of every leguminous plant.

A final proof of their theory was secured in this way: They used sand that lad been made sterile in every way: all organic matter was destroyed, and, of course, every kind of microscopic vegetation was killed-no bacterium of any kind was present in the soil. Some legume seeds were now planted. Just as soon as the nitrogen of the seed was exhausted, starvation manifested itself, and the plants began their decline. At this point, a water extract prepared from untreated soil-just ordinary garden soilwas adcled, but only a small quantity was used. In a very short time these starving plants began their improvement: they recovered their wholesome, natural color, assumed a vigorous, lusty growth, and reached full development, with no suggestion from that time on that any struggle or hardship had ever been a part of their existence.

Of course, the succor which came at the opportune time was none other than the friendly water solution that contained the germs fitted by nature to gather 11itrogen from the wandering air in the soil, and to transfer it to the starving plants.

Experiments, variously planned and prosecuted, were from now on in order. They served only to verify the concluding theory. The secret, at last, was learued, the n11ystery penetrated, and a new idea given the world. A 
wonderful achievement it was! And immeasurable in its results!

Has any statesman ever constructed a theory so useful? Has any politician ever devised a policy so far-reaching in its results? Has any soldier, with legions behind him, ever won so glorious a conquest?

Modestly, unassuming, and painstakingly, these men have labored, and have left to the world a legacy of untold worth, of unequaled largeness, and of most lasting endurance: one that shall be shared by all men alike, whether they be old or young, rich or poor, learned or unlearned. So long as men plow and sow, so long as men need bread and meat, so long as nations live and survive, so long shall the names of Liebig, of Boussingault, of Lawes and Gilbert, of Hellriegel and Wilfarth be honored and esteemed and glorified as world benefactors and as beacon lights of the human race. 


\section{CHAPTER XIII}

\section{THE RELEASE OF SOIL NITROGEN: THE RETURN TO THE AIR}

A very close relationship exists between the soil, the plant, and the animal. Each must perform its work that the other two may do their part.

Nature has just a simple plan: she stores in the soil and air the elements that plants require: she hands these same elements on to animals through the plant; for in the animal body are found the same chemical elements that are present in the plant. Plants, however, must come first: they gather from soil and air simple compounds from which they manufacture other compounds more complex in nature-just such materials as animals need. For all higher animals, you know, get their food either through eating plants or eating other animals that feed on plants. Hence, animal life is dependent either directly or indirectly on plant life for sustenance. Then the animal dies; maybe the plant dies: out of their decay and decomposition soil is made again or reënforced; air is given back the compounds it previously had lent the plant during its stage of growth, and of plant building. Thus the plant depends for food on materials stored in the plant, in the soil, and in the air; and the soil and air depend for their normal supply of elemental things on the plant and animal.

Here is the cycle: out of soil grows the plant, out of the plant grows the animal; from the plant and animal develops the soil.

Life and death.-Both life and death are concerned in 
this purpose of organization and disorganization: the first, an organization of simple materials into complex substances that animal life may be possible; the second, a disorganization of complex substances into simple forms that soils may be fertile, and that plants may feed well and properly.

Two constructive elements. - In all life processes, two constructive elenients-carbon and nitrogen-are especially active. The first of these, as we have learned, is obtained from the air, only-from the atmospheric zone in which leaves perform their important work in plant building. We have learned, also, that carbon, as used by plants, is combined always with oxygen, in what the chemist calls carbon dioxide: one part carbon and two parts oxygen, hence the formula $\mathrm{CO}_{2}$. An abundance of this compound always is present in the atmosphere, so much so, in fact, that plants are never carbon-starved, are never even threatened with a scarcity. For this reason, carbon supply is never a problem that concerns the farmer. He neither needs to know of the wanderings or of the duties of carbon. It is one of the elements, that, on all occasions, takes care of itself. Our interest, however, is here: carbon is our greatest constructive element, and the most abundantly used in the making of every organic compound.

The nitrogen problem more important.-In the case of nitrogen we have a different problem, and for this reason: plants get their nitrogen only from the soil. True, bacteria, when present in the soil, help in this work, with some kinds of plants, but when not present, these farored sorts are no better fitted to secure this needed element than are the less favored ones.

The two forms in which nitrogen is used by plants are: as nitrates and ammonium salts. The first finds immerli- 
ate acceptance by plants, and the latter, also, although not to the same degree-maybe only after passing into a nitrate form.

The fact that nitrogen is a soil constituent, and one that is easily and continually lost, makes the control of the nitrogen supply the most serious problem of crop production.

Original sources of the nitrogen of the soil.-The following are important sources of the nitrogen that plants use :

I. Organic matter from both the plant and the animal.

2. Ammonia that is given by air, rain, and snow.

3. Free nitrogen of the air that bacteria fix in the soil.

4. The chemical salts supplied from other places.

It matters not in just what form the nitrogen supply is obtained. The two great sources of this supply are: organic matter and the bacterial contributions.

Organic matter must be torn apart.-If the stores of plant food, locked in organic matter, are to be of benefit to future generations of plants, it is necessary for the many compounds contained therein to be destroyed: or ganized compounds must be torn apart and broken down into simpler substances. This work is done by decomposition, by decay and putrefaction, as we call them. The former takes place in the presence of air-when an abundance of oxygen is found and the latter only in the absence of much oxygen.

The agents back of these performances are bacteriatiny little plants that, unaided, neither eye can see nor ear can hear, as they go on with their work, performing their simple duties and their essential labors.

And what do you think they are working for? Simply carbon. They must have it. Just as birl or beast or man looks to starch and fat and protein for life and suste- 
nance-for the carbon compounds that give heat and energy, so do bacteria look to some similar substance in the soil for their supply. These little creatures are unable, of course, to take their supply in just the way that the

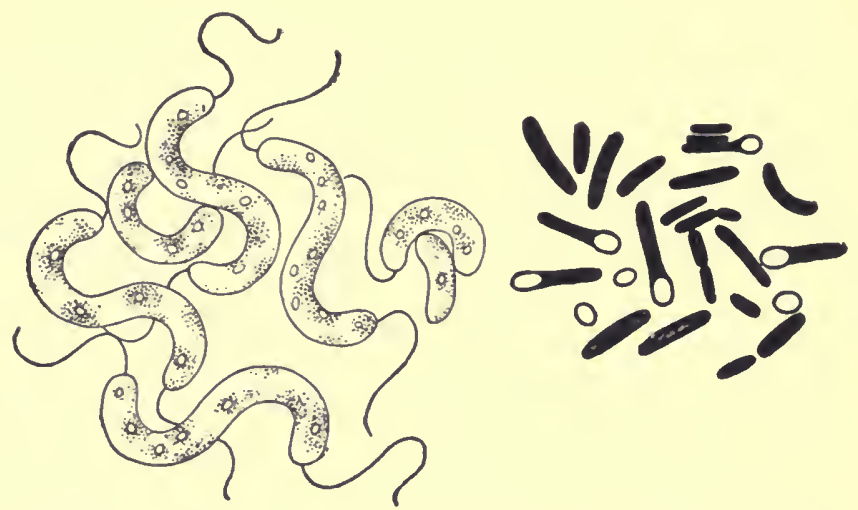

TWO KINDS OF BACTERIA FOUND IN DECAYING VEGETABLE MATTER (after Pfeiffer)

higher forms do: they have a way of their own. And why not? They pull compounds to pieces, they seize the carbohydrate therein held, and on it feed that their needs may be supplied. Naturally, then, when bacteria feed, they destroy organic matter. Organic compounds, since they are dead, no longer are able to resent and resist these attacks, consequently fall apart and sink into lower forms, at last to be destroyed entirely as a component structure. It is just the old story in reality: dust to dust and ashes to ashes. The plant dies, the animal dies-organic forms disappear and become mingled with the dust of the fields; and this becomes rich and fertile because of the dead therein enclosed: because bacteria have done their work well. 
These bacteria are everywhere present.-It is only recently that these bacteria have been introduced to us in a manner fitting their importance and even to-day we scarcely know them. Yet we are assured that whenever decay and putrefaction take place, there large numbers of these busy bodies are at work: some kinds down deep in the soil, where little oxygen finds its way; others near the surface of the ground, where air and food are more abundant; some kinds with vegetable substances, which peculiarly attract them;

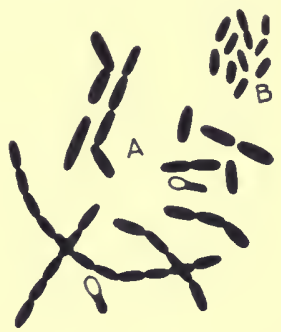

BACTERIAUSUALI.Y FOUNDIN DECAYING ORGANIC MATTHR

A. B. Mycoides: B B. Stutzeri (after Conn) and still others with animal compounds, which meet their iancy. In fact, you will find these bacteria almost everywhere: in air, in water, in milk, in all

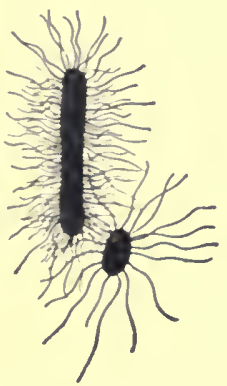

IMACTERIA FOUND IN DECAYING ANIMAL TISSUE (after Conn) vegetable and animal products, in the soil. When much available organic matter is at hand, these bacteria eat greedily and multiply rapidly, but when food is no longer available, they rest and sleep and wait until more appears.

Without bacteria there would be no decay.-Of course, this work must be done if plants are to be supplied with food. IV ithout these bacteria, the byproducts of the farm-manures, vegetable matter, waste and roughage of all kinds - would only accumulate, never decay. The soil would lose its lending power because its capital would be exhausted, and no means would be available that its replenishment might take place. 
The evil in bacteria.-So far, we have seen good only in bacteria: they destroy ten thousand useless things that, otherwise. would trouble man and load him continuously with burdens and difficulties. It is impossible to estimate the value or the extent of this useful work. But for all the good they do, bacteria have an evil side: they send nitrogen away from the soil. This must be said, however: that while decay and putrefaction bacteria have the power of freeing nitrogen from its compounds in the soil, they do so only to a limited extent, and only very slightly, indeed, where the tiller of the soil properly cooperates with them.

There are some forms of bacteria in the soil that make it their chief business to free nitrogen. They do this not because they have any spite against plants or animals, but simply in order that they may live. Here is the reason : they need some carbohydrate-a carbon compoundfor food; this they get from the organic substances that have been sent to the soil. But they need, also, some oxygen just as the higher plants. If air is not present in the soil-it is excluded often by water or bad textureoxygen becomes in demand. But from whence may it be secured? These bacteria have found a way through the long, long line of their antecedents: they simply seek out nitrogen compounds-compounds that contain both nitrogen and oxygen-and extract from them the oxygen they need, at the same time rejecting any nitrogen associated with it there. This nitrogen, now released, escapes its prison, rises into air, sails away, and becomes lost to the soil until trapped again by other bacteria-the good fairies that do this philanthropic act.

Denitrification: the nitrogen-freeing process. - The first effort in freeing nitrogen is that of changing the nitrates into the next simpler form, the nitrites. Not just 
one bacterium does this: bacteriologists tell us that a dozen or more kinds have been detected at this bad work. If some nitrogen compound, like sodium nitrate $\left(\mathrm{NaNO}_{3}\right)$, is present in the soil, these denitrifying bacteria, as a first step, seize onto it and take oxygen therefrom, reducing the compound-sodium nitrate $\left(\mathrm{NaNO}_{3}\right)$

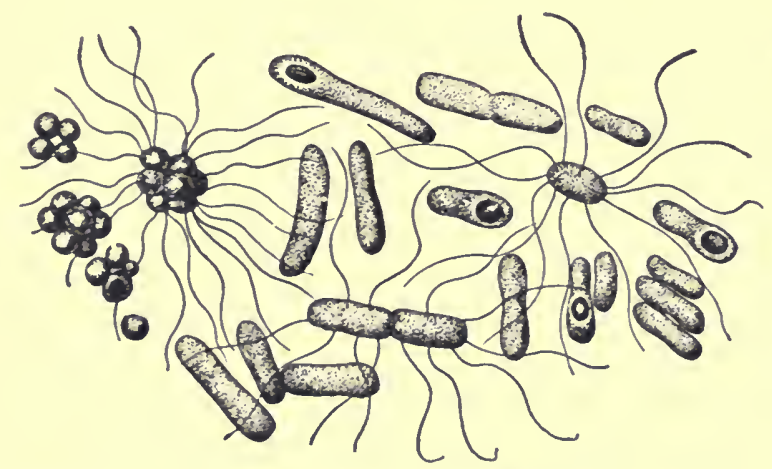

SOME BACTERIA THAT CAUSE THE FERMENTATION OF URINE (after Beijerinck)

-to a nitrite $\left(\mathrm{NaNO}_{2}\right)$. At this point in the reduction, another group of bacteria attack the compound-now sodium nitrite $\left(\mathrm{NaNO}_{2}\right)$-and obtain the rest of the oxygen, thereby setting the nitrogen free. The same is true of ammonia: either these same relucing bacteria or others similar in nature act upon ammonia salts in a way that frees the nitrogen from its combination, consequently causing its loss to the soil.

The significance of this is striking: it means that the most costly, as well as the most important. fertilizing element has leparted to the air, where it possesses no value to either plant or animal.

What the farmer may do. $-A$ very comforting fact, on 
the other hand, has been discovered. It is this: Denitrifying bacteria are slow workers when oxygen finds its way freely into the soil or wherever decomposition takes place.

If this be true, is it not good farming to till so carefully the land that air may find easy access to all parts of it? If water excludes air from the soil, is it not in line of good practice to get rid of it by drainage?

Certainly, this is the best method of battle. And a method that allows nitrates to accumulate and that weakens the ravages of all forms of reducing bacteria. The conclusion, then, is this: if nitrates and ammonium saltsthe forms that just suit plant roots-are to be protected in the soil, it is necessary to loosen and fine and open the land to air and oxygen. If these plant foods are to be increased, organic matter must be added in abundance but with this caution: you must send air into the soil; you must till it; you must drain it well; you must make its texture of the highest quality. And then plants will like this soil as a home. In it, organic matter quickly will be decomposed, and at the same time, the nitrogensupply content increased and protected, because that soil is mellow and open and of good tilth; because the things that do good and discountenance the evil of the nitrogenliberating bacteria, have been secured and supplied with great abundance.

Who shall withhold this method of nitrogen increase and nitrogen protection? This great power is in your hands. Who shall hinder you from using it.

The fault, dear Brutus, is not in our stars, But in ourselves, that we are underlings. 


\section{CHAPTER XIV}

\section{NITRIFICATION: NITROGEN MADE READY FOR PLANTS}

Every one familiar with the growing of crops knows that organic matter, when thoroughly decomposed and mixed with the soil, increases the producing power of the land; especially is this the case when nitrogen compounds are present in considerable quantities.

We have discussed the manner in which organic matter is decomposed in the soil. Bacteria do the work: they break into pieces every sort of organized life. A question now arises: What becomes of these simpler forms, now pulled apart and disorganized? One phase of this question has been answered already: some of the nitrogen has been given freedom: it has disappeared from the soil. The mineral substances, that were contained in the organic matter, are left in the soil. They cannot get away into the air. They will be available at once to plants, or else lost through drainage waters. They may join with other elemental forms already in the soil, and so remain until called into use by the enticing demands of future generations of plants.

The carbon compounds remain either in the soil or return to the air as rapilly as they are released from their combinations by decomposition bacteria. This departure may be in the form of marsh gas or of carbon dioxide. In either case, it offers no service to growing plants so long as it remains in the soil.

We now reach the important part of our question, and out of it grows a second. W' hat becomes of the nitrogen 
compounds that remain in the soil? That we shall attempt to answer now.

Just after decay nitrogen compounds are not ready for plants.-When nitrogen compounds are reduced from their complex forms-plant or animal tissue-by decomposition bacteria, they are unavailable plant food, still. They must be made to combine with more oxygen: they must be oxidized. Scientific men call this process nitrification. Organic compounds of nitrogen, when applied to the soil and decomposed, eventually oxidize to a nitrate, and then become usable plant food.

The chemical process. - In this disorganization of the higher and complex compounds, nitrogen compounds, like those of other elements, are reduced to more simple ones, reaching, finally, a point where nitric acid is formed. This acid now unites with bases or metals, producing compounds now known as nitrates. The common nitrates are: potassium nitrate $\left(\mathrm{KNO}_{3}\right)$, sodium nitrate $\left(\mathrm{NaNO}_{3}\right)$, calcium nitrate $\left(\mathrm{Ca}\left(\mathrm{NO}_{3}\right)_{2}\right)$, and ammonia nitrate $\left(\mathrm{NH}_{4} \mathrm{NO}_{3}\right)$.

Nitrification is a biological process.-Nitrification, at first, was thought to be a chemical process. The chemist had learned that he could do this same work in his laboratory : he could oxidize, under certain conditions, nitrous bodies into nitric acid bodies: he could oxidize unavailable plant food into available nitrogen plant food. But, in recent days, many things have been discovered about soil bacteria. Further study has revealed the fact, that some of these many busy bodies of the soil are back of this oxidization process : some of them cause nitrification : some of them change unavailable nitrogen into the desired form.

One way of proving this theory is this: secure a sample of soil which when mixed, divide into two parts. One 
lot now is sterilized by heating, that all bacteria may be killed. The other lot is undisturbed. Both lots are treated alike in all other respects from now on. When compared later, it will be found that the treated lot shows no increase of nitrates-of available food; while the other lot-where bacteria were permitted to go onshows an increase in this respect. Hence, nitrification, now, is believed to be a biological process: to be actually caused, governed and controlled by the bacterial life of the soil. Moreover, it is a two-fold process, for the reason that two sets of bacteria are at work. One set oxidizes ammonium compounds into nitrous acid-nitrite; the other oxidizes the nitrites into nitrates-the final form. A Russian scientist has demonstrated that these two sets are completely separated, that neither crosses the line into the other's territory, that each class does

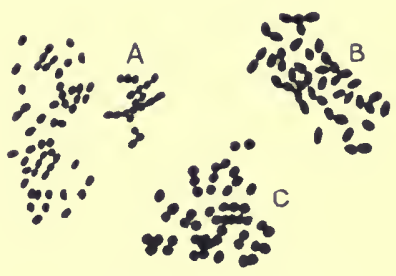

NITRIFYING BACTERIA

A. - Nitrococcus
B. and C. - Nitric bacteria
(After Conn) its own work. only. In short, that neither class is able to do the other's work. even if it would do so.

The bacteria that cause nitrification.-These workers are known now as nitrolacteria. The two classes are: Nitrous bacteria, called also nitrosomonus, and nitric bacteria, called also nitrobacter. As stated before, nitrous bacteria begin the work of nitrification: they change ammonium compounds into nitrites. When this is lone, their work stops: they go no farther, for they cannot. However, nitrification is not stopped, for at this point the nitric bacteria take up the work, change nitrites into nitrates, thereby completing the work originally begun by putrefaction bacteria. 
A striking peculiarity of the nitrobacter is this: they need no organic food. So far as now known, they comprise the only living form that is able to live in an environment wholly devoid of organic matter. Decomposition bacteria cease their labors when the organic matter is used up, but these, the nitrobacteria, only begin their work when such becomes the case, and so this is proved: nitrifying bacteria are inactive in the presence of organic matter for they labor only when it has been completely destroyed.

Nitrogen-starved soils may contain much nitrogen.All agricultural soils contain some nitrogen. Some may show considerable quantities and others but little. And of ten the latter class produce the best crops. A question naturally arises: why is this so? In the first place, other conditions being secured, crops are dependent upon a plentiful supply of nitrates in the soil. These, as has been shown, pass through various changes before reaching the final usable state. Nitrogen compounds may be present in the soil in great abundance, but until these are changed to nitrates, they are useless to plants. Hence, nitrification is essential. The bacteria must be stimulated in this work. It may be, decomposition of the organic supplies is slow; if so, decomposition bacteria must be induced to work with more energy. 'Tillage may help; lime may help. But the fault may be elsewhere: the decomposition bacteria may have completed their effort; they may have done every bit of work possible to do. Maybe the nitrobacteria-the nitrifying agents-are at fault. They must be induced to greater effort. If the soil is acid, the explanation is at hand, for these bacteria never work in sour lands. Liming the land may answer the question. And then tillage will help. It will admit the air, which certainly can do no harm, for air is just 
about as important as anything in way of favoring both the agents and the work they perform. Now, we may be certain of this fact: any soil that freely provides nitrates as a result of active nitrifications is in a high state of culture: it is ideal in physical condition and most highly remunerative when considered from every standpoint of land management and crop production. Every effort that induces nitrification in stubborn soils is rewarded by increased crops. Back of good crops is active nitrification and back of nitrification is vigorous bacterial life: back of all these are good tilth and good texture.

The evil and the good bacteria.-You will wonder just how this combat that is taking place continually between the denitrifying and the nitrifying bacteria will end. Thanks to the bacteriologist, we are able with considerable accuracy to answer the question. And the answer is not unfavorable to the nitrifying bacteria. It is well that we have these two classes well in mind. One class seeks liberty for nitrogen: it would set it free and send it from the soil. The other class would hold it tight, fast secure it in some nitrate, and there keep it until the plant roots come to take it away. Whenever organic matter is present in the soil, denitrification is taking place. If the nitrates are there, these tormenting things seek them out and tear them to pieces, and in so doing they let the nitrogen go. Just as soon, however, as this organic matter is used up, the nitrifying germs advance boldly to the front, the denitrifying germs withdraw, and nitrate-making goes on as before. It is well to keep in mind this suggestion: do not add any large quantity of organic matter to the soil when any considerable amount of nitrate is there present, for if you do, the nitrate will be reduced and much nitrogen will secure its escape from the soil. It is far better to supply fresh organic matter 
at that time of the year, when the soil is most nearly exhausted of its nitrate stores.

Observe how nature does: when lands have produced their harvests, they are low in nitrates-so nature brings in cold and frost and death. Organic matter is sent back to the soil from whence it came; and while winter storms and blows, and later passes into the warmer circle of spring, denitrification is not unlikely taking place, where no call is made for nitrates, for few plants are needing them. Consequently, when the time comes, when greater stores are necessary, the organic matter has been destroyed, leaving denitrifying bacteria largely inactive, and careless, and at the same time unmindful of the accumulation of nitrates by the nitrifying bacteria, now busy at work, and concentrating every effort to secure a maximum quantity of every fruiting plant.

What these facts teach. $-A$ knowledge of the way in which these many kinds of bacteria work ought to help in lessening nitrogen loss, in stimulating nitrifying bacteria into activity, and in increasing the yields of crops. In the first place, it is a mistake to incorporate raw organic matter with the soil, when the nitrate stores are already there in considerable quantities. It is also a mistake to apply organic matter some time previously to land where crops soon must fructify, for the reason that denitrifying bacteria may use more of the nitrate compounds than the growing crop itself. It is far better, in the light of these important soil findings, to apply organic matter during the fall or winter or early spring, when the stores of nitrates are at their lowest points. This, then, is the time when manure should go to the fields, when denitrification can take place without affecting the available nitrogen supplies of the soil.

We know, also, that the nitrobacteria-the kind that 
cause nitrification-are always inactive in acid soils; hence, nitrates are formed in such soils very slowly, indeed. When this is the case, lime must be applied so as to sweeten the soil; then the work will go on to the advantage of the bacteria working there, and to the farmer who seeks the crop.

Finally, thorough cultivation and tillage and drainage must be given, that an abundance of oxygen may be available to this working force in the soil. There will follow, also, a better distribution of moisture-a most essential factor of rapid bacterial development, and hence, of nitrification. 


\section{CHAPTER XV}

\section{RECLAIMING LOST NITROGEN: THE CALL TO THE AIR}

Nitrogen passes through its cycle continuously. Freed by bacteria, it slips into the air, there to remain until trapped again by other bacteria, when it becomes secure

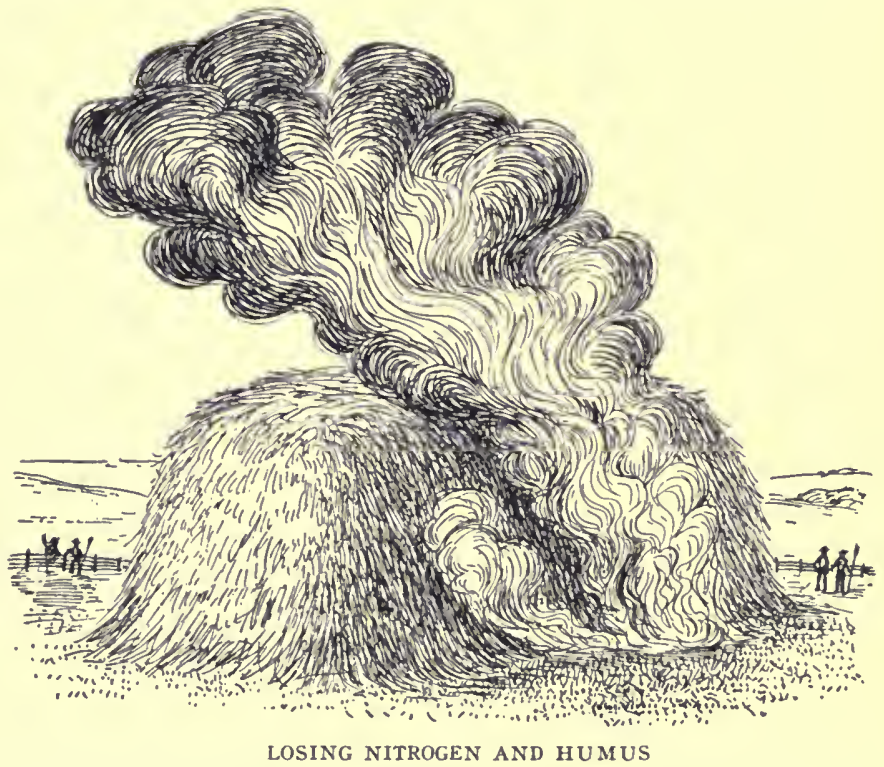

Nitrogen is too precious to be sent off into the clouds. Besides the rotting effect is needed in the soil. The trouble with old soils is: they need humus. Hence, never burn humus-making materials; let them rot in the soll

in plants or is held fast bound in the soils. Lost and then captured is the gist of the story: not one time, only, but so repeatedly that the change becomes a continuous 
change; and so it has been from the time that plants became fixed occupants of the land.

How nitrogen is lost.-There are other ways by which nitrogen is lost to the soil than that previously mentioned: the loss through denitrifying bacteria. The many ways by which these losses occur are:

I. The loss due to fire and chemical change.

2. The transfer of nitrogen to the ocean.

3. The loss of nitrogen salts in drainage waters.

There is no plan that may be suggested that will completely remove these losses. Some cannot be lessened, even. Fire is essential for heat and mechanical power. When wood, straw and other combustible materials are consumed, the compounds composing them are split up: mineral materials sink back to the soil (available for plant uses, if not lost), carbon and nitrogen, freed from their prison cells, fly off into the air and are reclaimed to the atmosphere; and water, loosed from the cords that bind it, vaporizes and joins its kind in the clouds above.

When these agencies are considered-their constant activity, their labors in every season and in every placeyou can realize, readily, the enormous quantities of nitrogen that are dissipated annually and lost, consequently, to the stores in the earth.

'The ocean gets its share, also. And a tremendous contribution it is. Consider the enormous quantities of human foods that, each year, go to cities and towns and other places of consumption throughout the world. The greater part of these immense stores reach the ocean sooner or later by means of sewers and streams and rivers-positively lost to plants and to man.

Then the loss of nitrogen in drainage waters is not inconsirlerable, either. This is more constant and larger than you may think on first consideration. Every rain 
that falls on the land dissolves some of the nitrates and other nitrogen-carrying salts and carries them with it as it seeks lower levels until finally it reaches the ocean, there to give over its findings and its stores to the greatness of the deep.

There is just one thing to say: nitrogen is lost.

Finally putrefaction and denitrifying bacteria are busy ever sending nitrogen away from the soil, even engaged in the work of stealing from plants and robbing the soil of its nitrogen stores.

Nitrogen is therefore lost, constantly and continuously. There seems to be no way of prevention, no way of saving these valuable stores. True sewage farms will lessen the contribution to the ocean, better tillage will check the loss through drainage waters, and better soil management will lessen the loss occasioned by evil-working bacteria. Still, with the very best that man can do, the loss can be diminished, only, but never overcome.

The problem: to reclaim the nitrogen lost.-Nitrogen loss, then, is not preventable: the call to the ocean, the demands of combustion, the determination of certain bacteria, are all so powerful there is no hope of complete remedy. If this be true, then this question is in order: How may the normal supply of nitrogen be maintained?

The solution of this problem is of most vital interest to agriculture and to the human race. The problem, itself, is the most important of all problems before us today. For these reasons: upon its solution rests the maintenance of the fertility of the land, and the production of food in sufficient quantities to supply all the needs of the entire living world: bread and meat, heat and shelter,every sort of food and raiment.

There is no cause, however, for alarm. Let those already disturbed and of little faith remember this: the 
way to solve this problem has been prepared already. The secret has been discovered. The rules are being practiced by many to-day: they are easily performed: they are very practicable. In short, nitrogen free may be so treated and trained that it readily acquires its useful habits again, so that plants may use it just as they did in other days before freedom was given it.

Nitrogen fixation in the soil is now a reality, as it has been a reality always. The secret has just been revealed to us: the story has just been told.

Nitrogen is fixed in the soil.- The little microscopic plants within the soil are the agents of nitrogen fixation, not those that once released it, nor those that cause the decay and putrefaction of organic forms that hold it, nor yet even those that change low nitrogen forms into nitrate salts-none of these. Other kinds of bacteria, other tribes, are the agents of fixation. While similar in all habits of life, their work is not destructive. It is constructive and of another order, entirely, than these heretofore mentioned.

Xitrogen-fixation bacteria call to the air, and. in response to this call, nitrogen leaves its atmospheric environments, goes to the bacteria making the call, and does their biclling.

Our scientific men, to-day, tell us with positiveness that outsicle of electric discharge at least two ways are open for nitrogen fixation: (I) The acpuisition of free nitrogen, through the agency of bacteria, in the soil; (2) the accuisition of free nitrogen by bacteria that live on the roots of leguminous plants.

In reference to the first proposition, it has been proved, abundantly, that atmospheric nitrogen is fixed in the soil in some way; most probaloly it is associated with the growth of micro-organisms. This is ratler clearly shown 
when heat is applied to the soil: the nitrogen content remains unchanged. On the other hand, the same soil shows an increase in nitrogen if untreated by chemicals, heat or other influences that endanger or destroy the floral life therein contained.

While safe enough evidence shows that soils do have the power of fixing nitrogen, it is to a very limited degree, only; it is too little, in fact, to base upon it a rational system of farming.

Early experiments suggested the advisability of cultivating these friendly bacteria (whose work it is to capture atmospheric nitrogen) and so treat them that they might work more effectively, at least to send them into soils where they had not gone previously, thus giving them unusual work to do-in all soils, in all sections. Some European investigators went so far as to prepare a culture that should be able to do the work.

A better way was found, however. It is this: Get the right conditions in the soil that permit a favorable development of these bacterial germs rather than inoculate the soil, since the germs are usually present in the soil and inactive only because their environments are against them. To make them active, give to the soil every influence that shall stimulate the bacteria to vigorous activity, that shall make them healthy and robust, even eager to secure the nitrogen of the air and to fix it in the free soils of the fields. Soil culture, thorough tillage, and soil manipulation, therefore, are to be preferred, in fact, these are indispensable, if the helpful coöperation of these soil workers is to be had.

More is needed: let legumes help.-But this help is all too little. The farmer must have assistance more abundantly and more laden with good results. This may be obtained by coöperation with the legumes. They act 
quickly: they act with munificence: they act constantly. It has been known for some time that the legumes were not soil depleters, as wheat or corn or cotton-as every other form of plant: they always helped the plant. In what manner no one knew. But this was observed: when corn or wheat or other cereal followed clover or other legume, a much greater yield was secured than on similar land, similarly treated, but without the legume crop. The evidence was so conclusive that long ago clover and peas were hailed as soil improvers and land builders. Of course, their goodness was never associated with bacteria. While the peculiar nodules were observed on the roots of these special plants, they were believed to be disease evidences rather than homes of friendly-working bacteria.

It has been noticed in a previous chapter that Lawes and Gibert in England made some extensive experiments with the legumes and that their observation showed nothing favorable from their use. You wonder why? Here is the explanation: they never had the aid of the bacteria. the good fairies of this work. These investigators were so careful that no error should creep into their work, they eitler never got soil possessing bacteria, or because of sterilization or of the chemicals used, the development and, hence, the good work of these nitrogen gatherers was prevented.

Root tubercles: the place of nitrogen manufacture.Have you ever noticed the swellings that appear on the roots of such garden plants as peas and beans or on any such field crops as clover and alfalfa? No? Well, they certainly are there if your crops are growing abundantly and vigorously. You will fincl roots of sucl crops often largely covered with wart-like growths. These are the homes of nitrogen-gathering bacteria. Some people call 


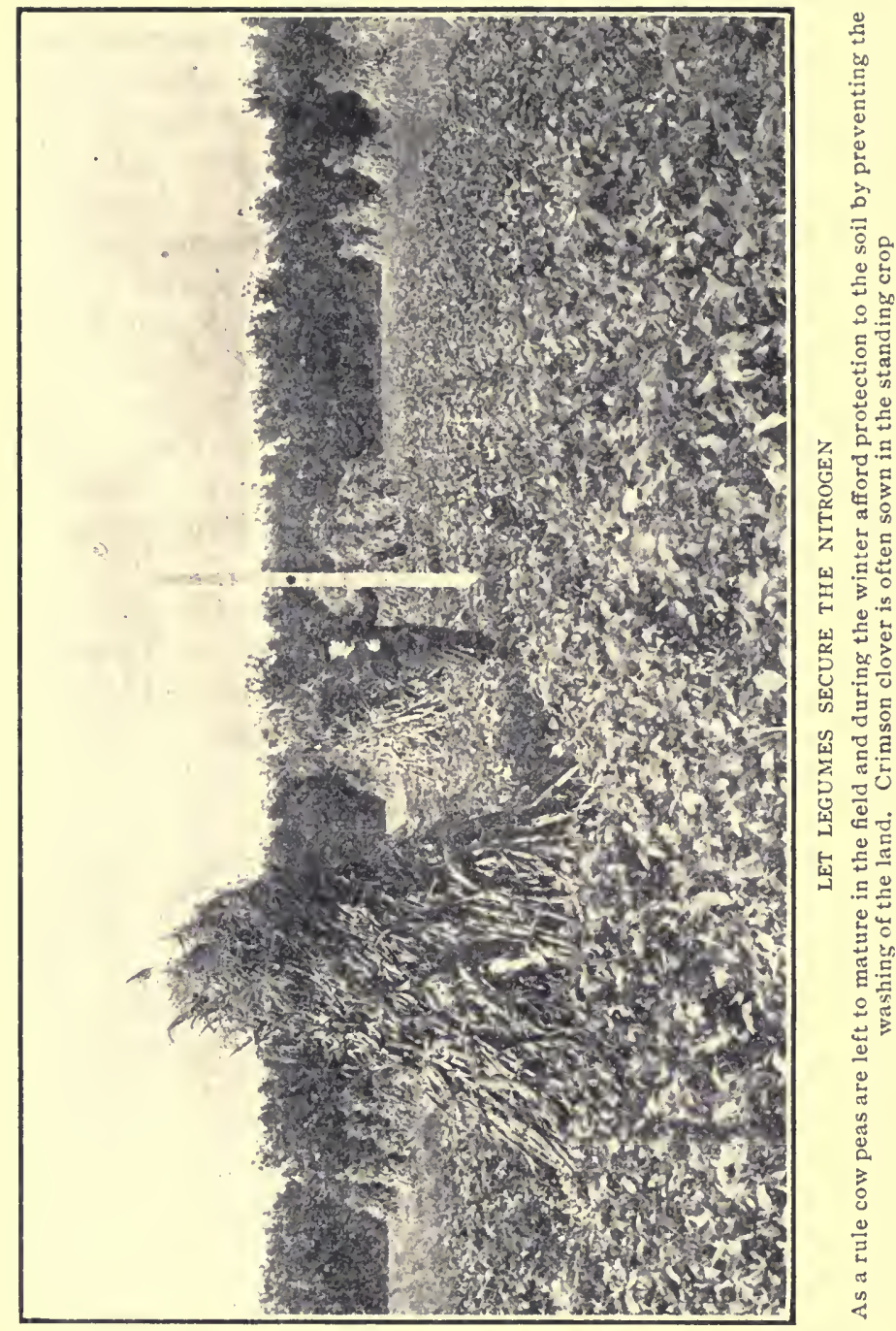


these dwellings tubercles or nodules. It matters not what the name is: the work accomplished is the matter of consequence. These nodules are often very largeas large as a pea. And then again they are small-as small as a pin head. Just as soon as these nodules or tubercles were associated with bacteria and bacteria with nitrogen fixation, many experiments resulted in consequence. The result of these investigations led to the solution and the explanation by Hellriegel and Willfarth in 1888 of this knotty problem: they told how free nitrogen is fixed in the soil.

A word about these bacteria.--These little plants are real bacteria: thread-like bodies that send their advance

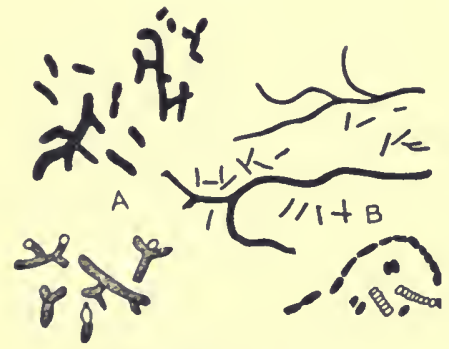

ROOT TUBERCLE BACTERIA

(AFIER MAZE) scouts throughout the roots, into all tissues of the roots.

Bacteriologists tell us that these bacteria are not just like other bacteria. They differ in some ways from all the other kinds. They seem to belong to a class of their own in methods of growth and development. In reference to them, Conn, a noted bacteriologist, has this to say: "At certain stages of development, by branching or budding, they produce what are called $\mathrm{Y}$ and $\mathrm{T}$ forms, a method of growth not characteristic of bacteria, in general. It is found, also, that after the beginning of the formation of the tubercle, long, thread-like masses, filled with bacteria, can be seen extending among the tissues of the plant. The long threads appear almost like pouches in which the bacteria are held, but they eventually disappear and the bacteria themselves diffuse through the tissues. 
These phenomena, the $\mathrm{Y}$ and $\mathrm{T}$ forms and the pouch-like threads, have been puzzles to bacteriologists, for they are not characteristic of any other bacteria known. It has been doubted whether the organizations should be called bacteria."

But whether these are bacteria or not, the fact remains that they are responsible for nitrogen fixation, and hence, they are soil builders and world benefactors.

Suggested ways in which fixation is done.-We are certain of this fact: nitrogen is fixed in the soil in a form in which it is assimilable by plants and especially usable by the legumes. We are not certain, on the other hand, of the manner in which this fact is accomplished.

Four theories have been suggested, as follows:

I. The bacteria (bacillus radicicola) fix the nitrogen.

2. Legumes fix the nitrogen, the bacteria being the stimulus of the act.

3. A combined act of the legume plant and tubercle bacteria in assimilating nitrogen already fixed in the soil by other bacteria but unassimilable until legume and tubercle bacteria act on it together.

4. Symbiosis: A combined act of the legume plant and tubercle bacteria in gathering nitrogen from the air.

In case of either theory, the legume plant is inseparably associated with bacteria. The question arises: How is the work done?

The first theory allows one conclusion: bacteria do the work entirely of themselves. The only value of the legume is its offering a suitable dwelling spot for the workers. While some evidence points to this theory, but few accept it as an explanation of nitrogen fixation.

The second theory, that the legumes fix the nitrogen after being stimulated by the bacteria associated with them, is not generally held, although its advocates boldly 
declare such to be the case, some even insist that other plants besides the legumes have the power of nitrogen fixation. They say that some plants other than legumes fix nitrogen to a slight degree, only, still they have the power. If this theory is correct, it will lead, doubtless, to still greater helpfulness in maintaining the fertility of the land.

A third view of nitrogen fixation is this: Some bacteria in the soil-just what kind we do not know-seize on the nitrogen as it moves about in the soil with the air and hold it fast, by placing it in some compound unassimilable as plant food. A second step is then made: legumes and tubercle bacteria couple their efforts and nitrogen passes into a state that plants can use. It is fixed nitrogen: it is real, usable plant food.

The symbiotic theory finds a larger coterie of advocates. It is the theory of mutual helpfulness: the legume helps the bacteria by furnishing carbohydrates and dwelling places for them: the bacteria help the legume by furnishing nitrogen as rapidly as it is needed for all uses of the plant. This theory renders each party dependent upon the other: without a legume there is no dwelling place for bacteria and without the bacteria there is no nitrogen for vigorous growth and abundant fruit for the legume plant. Hence, this is a theory of coöperation, of harmonious mutual service: one helps the other; both are materially bettered because of the other.

The point that is important.-We need not concern ourselves particularly about these theories. The best plan is to leave them to the scientist, who sooner or later will clear up the matter. Nor does it matter. The good work will go on just the same: legumes and bacteria will continue to adel the fat to the land: they will continue to enrich the farm; they will continue to do this work 
whether we know just how they do it or not. We can spend our time to better advantage by helping both in the field where the work is to be done: by opening the soil that air (and hence nitrogen) may be passed to them

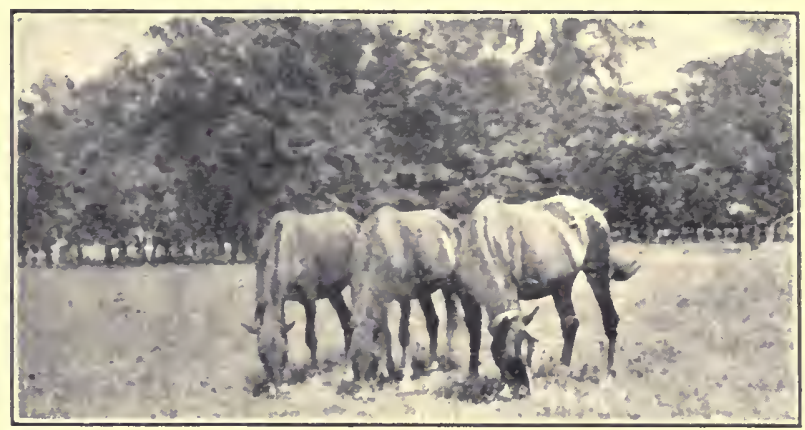

BACK OF GOOD TILLAGE IS THE WELL-BRED FARM HORSE

in abundance, by keeping the soil mellow and fine and sweet, that the little workers in the darkness below may work with advantage to themselves and with profit to their master. 


\section{CHAP'TER XVI}

\section{SOIL INOCULATION: HOW DONE}

Successful farming now is associated closely with the growing of leguminous crops. Why this is true we have seen: leguminous crops when aided by tubercle bacteria catch the nitrogen of the air and fix it in the soil. There remains. still, one phase of this subject to be considered: Is the farmer able to incluce bacteria to visit his lands and to work there in conjunction with the legumes, if heretofore they have not been there? This question can be answered in the affirmative. But if you would have such visitors remain with you always, you must do your part in making their new home comfortable and satisfactory to them. Otherwise. they will die. Perhaps they will do just as others before them may have done: they may be unable to help you and also, at the same time, be unable to live in the quarters you have for them.

It follows, then, if you would have their help, you must do your part: you must keep the soil free from stagnant water; keep it sweet and free from all bacteria-destroying acids; keep it open and mellow and fine; keep it free and attractive to air and like wholesome influencesthen bacteria will come and flourish and do their work.

And then bear in mind that legumes can be of no more value in soil improvement than cereals or other nonleguminous plants, if for any reason the assisting bacteria are forced out of the soil. You must get these little assistants at work again, if, perchance, they have departed. And if they come for the first time, let nothing interfere in the way of their remaining. 
What inoculation of the soil means.-Not all soils contain just the sort of bacteria needed for the legume that you may desire to grow. Some soils never have had legumes growing in them, and hence, the particular bacteria needed may not be present then at all. If this is the case, the crop will do but poorly, especially if the land is old, deficient in vegetable matter, and worn out. To prepare the way, the soil must be inoculated: bacteria must be introduced into the land. You know how the yeast plant is employed in bread-making, just a tiny bit of it is used. When warmth and moisture are supplied these yeast plants develop rapidly and soon leaven the whole. So with the bacteria of the legumes. In the first instance, with no yeast, there can be no "rising" of the bread, while in the second, with no bacteria-those of the right kind-in the soil, there can be no formation of the tubercles on the roots of the legume. Hence, the need of inoculation, if the wished-for end is to be attained.

Each legume has its own worker.-One of the first steps of inoculation is to get the right bacteria, for the reason that each legume has its own bacteria with which it works-personal servants peculiarly loyal and devoted to it. Thus the bacteria that are allied with the cow peas positively refuse to labor with the alfalfa or with the clovers. These bacteria would rather die, than seek dwelling places on the roots of either alfalfa or clover. But the same peculiarity is true of alfalfa and clover bacteria: these behave in precisely the same way to the cow pea or to the soy bean, as their relatives do to their lords and masters. In other words, each legume becomes a favorite abiding place for some special kind of bacteria, and long coaxing is necessary in order to get them to do differently. In a few cases bacteria are known to be more plastic, burr clover and sweet clover being two exam- 


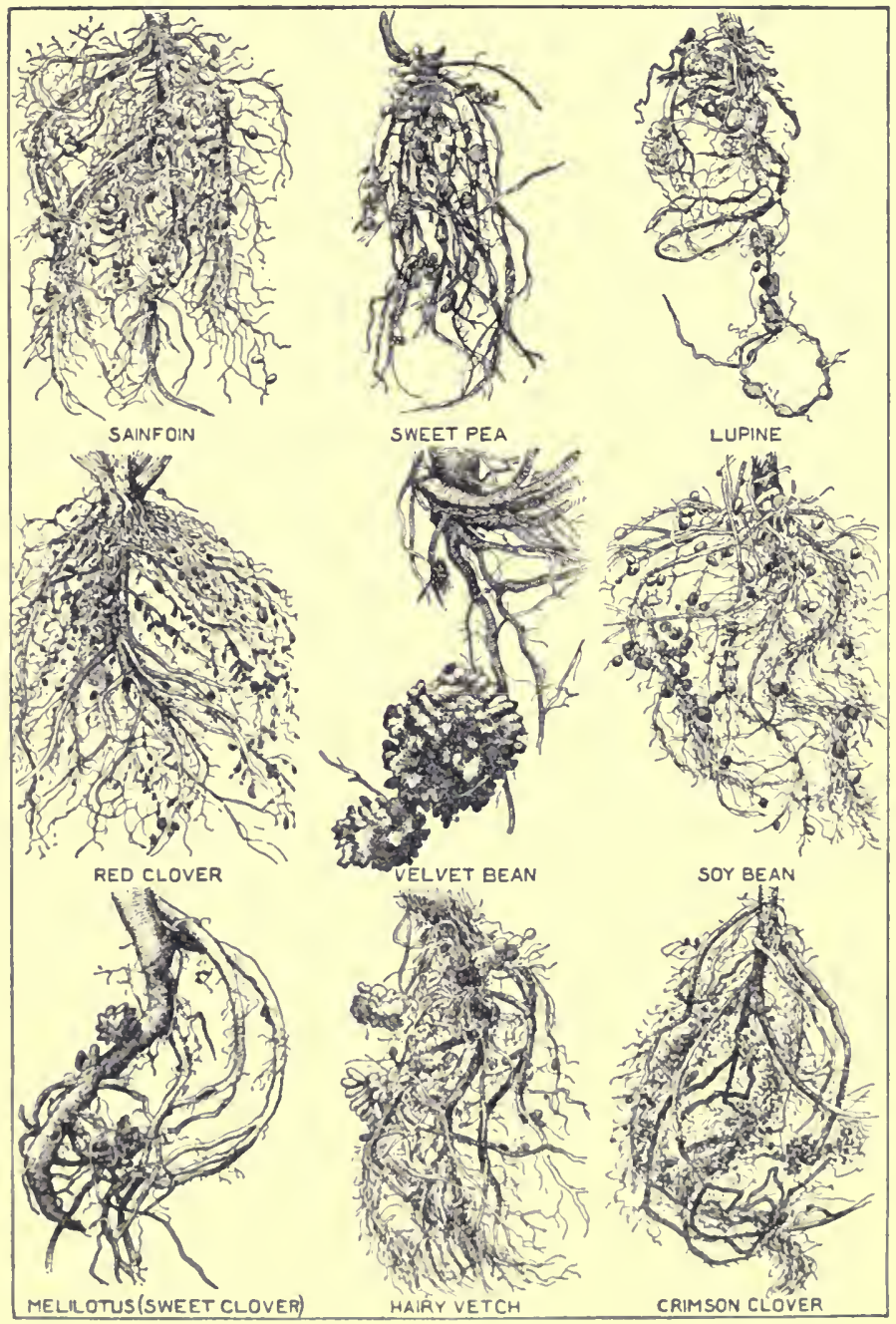

SOME LEGUME ROOTS SHOWING ROOT TUBERCLES 
ples that lend their silent servants to alfalfa with no noticeable resentment on the part of the bacteria. It is not the rule, however. Born within their caste, it seems out of the question for bacteria to escape the borders that enclose them. It is no doubt true that these many kinds of bacteria-each legume has its own-came from a common ancestry, when all legumes were served alike, and before wide differences became manifest.

As an example of this, we have only to refer to the experience of all alfalfa growers in those sections of the country where this crop has been introduced only recently. Although some other legume may have been grown repeatedly on the same soil, no assistance seems to be afforded the alfalfa plant until first there is supplied to the soil the specia! bacteria that have grown accustomed to this legume.

Bacteria may act slowly at first.-It often happens, also, that when legumes are grown in a soil for the first time, neither they nor bacteria do very effective work. Either they have not got acquainted sufficiently to work in harmony, or too few bacteria are present in the soil. I have observed this a number of times, and with several legumes. The first season but little is done: the roots lack vigor and possess but few nodules, the stalk is slender and lacks hardiness, the leaves are pale, and poor health is generally manifest. In the second season a change is noted: in each respect just mentioned there is improvement and betterment. And often a third year, even, is necessary in order to secure vigor, strength, color, yield and size-just as you would have them. An examination of the roots shows that an abundance of tubercles is obtained, often, during the second season, and usually by the third. Plants and bacteria now work in harmony, and both prosper. 
You should not despair, therefore, if appearances are against the crop during the first or second year. Just keep at work and repeat the operation a second or even a third time. The bacteria will come and work. The land will be saved!

When trying a legume for the first time, give it a chance. If it fails to meet your expectation, do not despair. But refrain from blaming the legume, nor blame the bacteria, either. Just repeat the experiment, and on the same land. Give both time to join hands, to get together and acquainted, to adjust their characters to suit each other's peculiarities; and, above all, give the bacteria time to increase and to multiply and to fill the land with their kind. Then the work will be done with ef fectiveness, just as it will be done to your profit and advantage.

Many ways of inoculation.-There are three ways known of getting bacteria into the soil, if not already present there. These three ways are:

r. By introducing soil from a field known to contain the desired bacteria to the field where it is desired such bacteria shall be.

2. By soaking seed in water in which soil from a field where the legume has been successfully grown, has been stored.

3. By means of pure cultures of the specific organism suited to the legume.

The first way suggested represents the beginning of soil inoculation. It was effective, as it is still to-day the most effective. There are oljections to this method, however. It is an inconvenient method of doing the work; it tends to introduce noxious weeds; and it spreads plant diseases; hence, the reason for the "pure-culture method." 
Inoculation by means of soil.-If this method is to be used-whether obtained from nearby fields, or shipped long, distances-the evidence should be clear that the soil is free from the objections just stated. Here is the plan: take soil from some field known to contain the desired bacteria. Does this soil yield the legume abundantly? Do you find tubercles on the roots? You do. Then that is good soil for the purpose. All you need to do is transfer this already-inoculated soil to the land that is to receive the good fairies of the land. If this soil is fine and mellow and of good tilth, if it is well drained, either naturally or artificially, if it is free from distasteful acids, then other things being equal-the plant at home in its environment, the soil suitabie to it-the crop will grow, the bacteria will prosper, the land will yield forth its fruitfulness.

In getting the soil, it is best to go down where the roots grow-not the top layer. A layer between two and six inches from the surface will be just about right. Apply this soil to the field that is to be inoculated, or else mix with the seed, slightly covering with the harrow.

And now another question: How much soil is necessary? Not much. Just 200 to 500 pounds per acre will do. If the soil be in good condition, a small quantity will leaven the entire mass, the entire solid body. On the other hand, if the soil is bad, physically, a larger quantity may be better-twice the quantity previously suggested. In either case, mix with other soil-just common soil of the field-and then harrow for even distribution. That is all there is to inoculation when inoculated soil is used. Once done, it is always done, provided the legume crop is not neglected for too great an intervening period.

Inoculation by soaking seed in soil and water.-The second suggestion is often used in practice now. Soil is 
obtained and enough water used to make a muddy solution and in this the seed is soaked, after which it is dried and sown.

The "pure culture" idea.-This idea is not so recent, as you may have been led to believe from the foolish and erroneous advertisement that has been given "pure culture" inoculation. Several years ago two German scientists worked out this iclea, and prepared pure cultures of the several bacteria suited to the important legumes. These cultures were called nitragin and soon gained considerable commercial attention, even finding their way across the waters to us on this side. But these cultures failed, when asked to work outside of European lands. Soon after the advent of nitragin, Moore brought out his so-called discovery and invention. It was hailed by magazines and many agricultural papers as a panacea for all the ills of the soil. While often successful, this

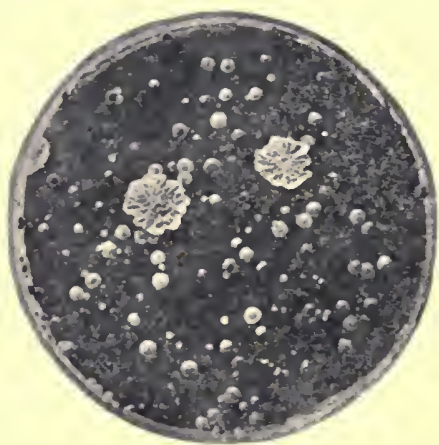

GROWING BACTERIA IN THE LABORATORY

methor is still in the experimental stage. It promises much, however.

Following is the Moore plan of such cultures for commercial use: bacteria were grown on nitrogen-free media; they got no nitrogen, and hence were starved, the idea being that when g;own later in their natural habitat, their nitrogen appetite would be quickened. The next step was to lay these away in cotton and dry them, that journeys to distant points might the more easily be made. But the plan was not satisfactory despite all that has been 
said to the contrary. While it is true that many tests were made in actual field operation, only to per cent. were in any degree successful. It is not known just what per cent. of these trials would have shown like results, even though no inoculation had been made. Certainly, the results have been most disappointing, and a most interesting theory has come to naught.

It is to be hoped the new plan of liquid pure-cultures will be tried and proved before given over to spectacular advertisement, as was done with its parent predecessor.

Inoculation secures nitrogen only.-Let this be clearly understood, also: no sort of inoculation-inoculation soil

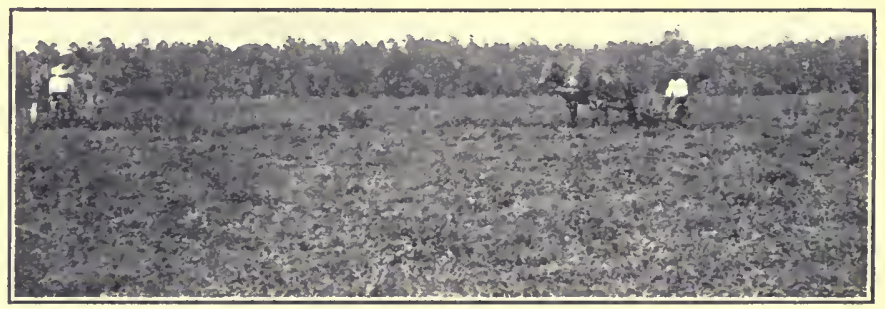

ALFALFA : THE BEST ALL-ROUND CROP IN AMERICA

or pure culture-is able to provide other elements than nitrogen. Nor can nitrogen be got save through the use of a legume crop. This idea is repeated here, that it may be understood clearly that inoculation has to do only with nitrogen, the legumes and the bacteria associated with the two. In this way, only, can you secure any reward for time, labor and money expended in the pursuit of nitrogen.

The legume to select.-In selecting a legume that shall serve in the capacity of a nitrogen gatherer for other crops, you will be governed, naturally, by circumstances. 
If your soil is sandy in nature, you can expect but little from clover. Cow peas and soy beans will do the work a great deal better. Give these legumes a trial there. On the other hand, if you want a more permanent legume for loam or clay land and one that will last longer than for a few months, only, then select clover. It adjusts itself readily to every sort of rotation; it is easily sown and it makes a good pasture crop or a good hay crop-you can take your choice. But even if you use cow peas, and soy beans and clover, you certainly ought not overlook alfalfa. It is the best all-round crop in America: good for feed and good for the land, good for consumption on the farm, and good for sale: the best money crop, the best feeding crop, and the best crop for the land.

Conclusion: Points to bear in mind.- -1 . Inoculation is a good thing:

(a) When a small amount of humus is in the soil.

(b) If previously-grown legumes lacked nodules.

(c) If the legume is used for the first time, and not closely related to the previously-grown legume.

2. Inoculation may help:

(a) When the crop grows poorly, although some nodules are found.

(b) When the start was good, and the seed poor.

3. Inoculation is never needed:

(a) When an abundance of nodules are produced already.

(b) When the soil is supplied already abundantly with nitrogen.

4. Bacteria are not plant food.

Neither bacteria nor the cultures of nitrogen-fixing bacteria are to be regarded as plant food. A bacterimm is not nitrogen, nor is it composed of nitrogren. It renders nitrogen of the air available for the legume. 


\section{CHAPTER XVII}

\section{DRAINING THE LAND}

A wise man once was asked: "What is the most valuable discovery in agriculture?" He answered: "Drainage."

In draining the land, we are concerned, for the most part, with the surplus water and its removal. For drainage acts thus: it removes the gravitational waterthe kind that often injures plants, the kind that drowns the roots, and it increases the quantity of capillary water - the kind useful to plants, the kind that draws into solution the needed plant-food salts, and secures them for roots and stems and leaves and for all the growing tissues of the plant.

Here are some of the good things that drainage does:

I. It deepens the soil in which grow plant roots.

2. It better aerates the soil.

3. It enables manure to act more beneficially.

4. It allows a better warming of the soil.

5. It lengthens the season.

6. It permits tillage operations to be done more easily.

7. It enables plants to resist drought, because the roots go into the ground earlier in the season.

8. It prevents washing.

9. It makes the soil more sanitary.

Io. It makes better crops.

Deepening the soil.--It is perfectly evident to any thinking man that a soil that is well drained is a more habitable place for plant roots, than one filled with standing water. We do not need to theorize about this propo- 
sition. You need only to observe, as you pass along any highway, to see how slight is vegetation, and how sickly are cultivated crops on lands not drained. A soil that is constantly saturated with water will not permit a good growth of crops. The essential conditions for growth are wanting. It is understood readily that where a tile drain, or, in fact, any sort of substitute, when constructed and placed three or four feet below the surface of the ground, the water level is naturally lowered to a point on a level with the bottom of the drain. Drainage, therefore, provides a large pasture ground for plant roots and a deep one, also, as a consequence, for all time to come.

You have proven, in your own experience, that roots will not grow in a soil saturated with water. They try to do so for a time, but soon sicken and die. If the water table is only Io or 12 inches below the surface of the soil, the roots are obligerl togrow within that limit. But if the water table is lowered another foot, the feeding and growing limit for roots is deepened and, consequently, enlarged, to the benefit of the plant and to the erop.

Perfectly drained soils, drained to a depth of three or four feet, show plant roots throughout this body limit. It stands to reason that such a root-foraging ground is

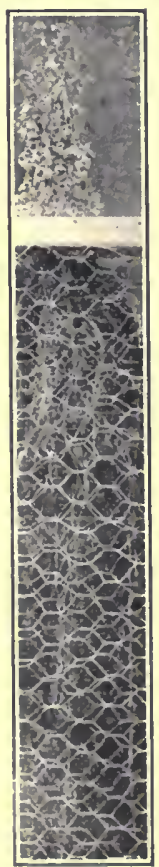

RED CLOVER ROUTS

Showing why the soil should be deep more desirable than a shallow one, made so by a high water table near the surface of the ground. And lere are the reasons: there is more room for the roots; there is more plant fool to be secured ; there is more warmth in the soil; there is more air to be userl; hence, there is 
a more comfortable home for the roots provided in drained land.

Air gets into the soil.-It has been pointed out that both air and oxygen are essential for good root development, as well as for high crop production. But air and oxygen are excluded from the soil when water fills up all of the air spaces in the soil. Drainage removes this water and, hence, increases the air content of the soil. Air goes just as deeply into the soil as the water table allows, and as it goes down, it leaves all along its way its helpful gifts-scores of beneficial influences that stand for better crops.

And still two other things: It supplies the roots with oxygen, and it breaks down complex substances, fitting them for the call that other plants soon will make.

Manure is made more effective.-Vegetable matter and other humus-forming materials are of no value in the soil, until they are thoroughly decomposed and destroyed. Hence, it follows that good results, from the use of manure, will be obtained in the highest degree only when the rotting influences of the soil are best.

For undrained soils do their work in this respect very unsatisfactorily. The drained soil makes the best use of manures. It has been shown frequently that chemical manures are used most wisely in connection with high physical improvement only, with good tillage, good drainage, good cultivation, and with a free use of humusmaking materials.

There is in this connection another point to be considered: Useful bacteria find favorable development only in the presence of an abundance of oxygen; they find enjoyable the work of breaking down compounds, and of building up nitrates, only when air is furnished abundantly, and when the soil is open and warm and sweet. 
But they do not like wet soils and in them they do but little work. On the other hand, much work is done by the nitrogen-freeing bacteria: the evil-doers which release soil-nitrogen, and send it back again into the atmosphere. Here is the way these bacteria work: When given soils that are well drained, good bacteria add to the nitrogen store; when given soils that are wet and undrained, evil-doing bacteria rise in power and take from the stores in the soil. In the first instance, constructive workers are at hand and in the second, destructive ones. Consequently, if you would have the help of the beneficial and would drive the harmful away, and, at the same time, have manures of all kinds most effectively used, you must pay close attention to draining the land.

The soil is made warmer.-- Wet soils are always cold. And since warmth is necessary for both germination and

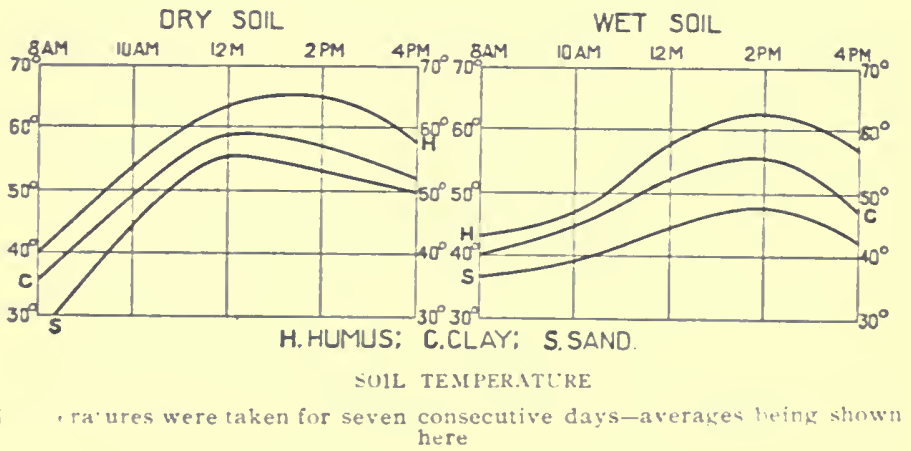

for active growth of plants, it follows that wet soils never can equal well-clrained ones when it comes to high production. It is out of the question to expect otherwise.

The season is lengthened.- I et soils often become dry 
in the summer, when hot and dry weather is the rule, but for a period so short no paying crop can result. $\mathrm{Na}$ ture is too slow here and your work will be unsatisfactory and unprofitable, if you depend upon her, alone, to drain areas naturally wet. Better not do it. Use tiles instead. The first noticeable difference, after drainage is done, is the lengthening of the growing season: work may be begun earlier in the spring and it may be extended far into the autumn. This means that stagnant water is removed from the land, both in the spring and in the fall,

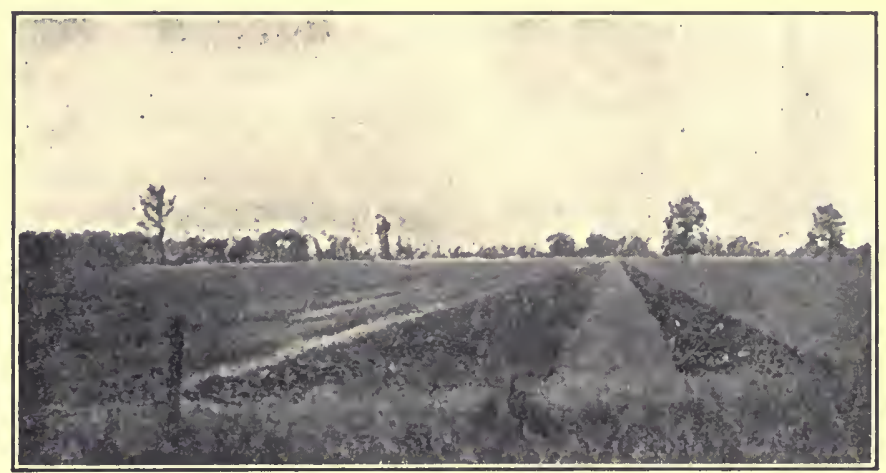

A WAY TO HELP THE DRAINAGE

Plowing clay in eight-step lands

to the advantage of your work, your crop, and yourself. You can handle, often, well-drained soils three to five weeks earlier than like soils in an undrained condition.

Tillage is more easily done.-Soils are injured frequently (if not ruined for the time being) by tillage operations, if done when the land is wet. It is perfectly evident, therefore, that a soil undrained, either naturally or artificially, makes all tillage operations a burden, and the work a drag. 
Plowing is done often later in the season, consequently often unsatisfactorily, and the crop suffers, for it is planted in haste; and, as a result, it is hindered throughout its period of growth. Drained lands are easily tilled and easily cultivated. They permit all tillage operations to be done easily and satisfactorily, and at a time when most urgently needed or demancled.

Less danger of drought.-One of the proved facts that scientific investigation has shown is this: a soil contains more available moisture after drainage than before. The explanation of this seeming inconsistency lies in the fact that the physical condition of undrained soil is being improved: the soil is made loose and mellow; the soil grains are more open; and the interspaces admit and hold air-the capillary water is more frecly introduced, when demanded, and more readily handed out to the roots, as they call for it.

Just bear in mind that stagnant water is of no help to plants. They cannot use it. Furthermore, it is repulsive to them. lietter get ricl of it, depending rather upon the subsoil and the capillary tubes composed of the soil grains, for the water supply during a complete growing period. Of course, rains are to be desired-they are positively needed for most lands-but their waters must be taken into the soil and distributed into all of its parts: a tiny bit must be given to each soil grain to hold and to care for until some root forces it away. And all surplus amounts must be carried away, that no injury may be done either plant or soil.

When you open and mellow and fine the soil you increase the moisture content of the soil. When this is done, a larger store of water is secured in the soil, down to a considerable depth, all of which will be available, 
when dry weather arrives, furnishing what wet soils fail always in doing.

Washing is prevented.-If a soil is saturated with water, the only means of escape for rains is by means of surface washing, a most injurious operation for the soil. For this reason: surface washing picks up dissolved plant food, and fine particles of soil, and carries both to lower

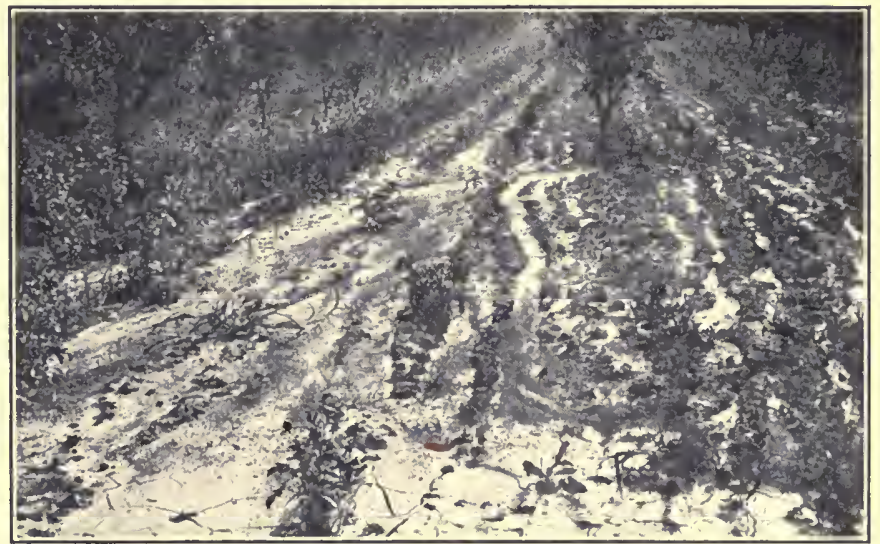

LOSING SOILS BY HEAVY RAINS

The loss of surface soil by washing is often very serious. This soil has been washed to the edge of the field and down into the gulch: it is the finest and richest soil. If the plow had been run deeper. and the land had been cultivated crosswise of the slope, instead of lengtlowise, it would not have been waslied so badly. This soil needed cultivation aiso. Note the crust and cracks at the bottom of the picture; no wonder water does not get into the soil

depths. I have seen vast areas, gullied, and ridged, and torn, and made so by surface washing of the land.

Often plowing is done poorly: so shallow that rains never find their way down into the soil, carrying as they go their good eflects to the lower depths; but, on the other hand, they flee along the hillsides, carrying away treasures that are valuable and sadly needed, just where 
they are-taking them from the place where most able to do good. Drainage provides, therefore, both an entrance into, and, at the same time, an exit out of the soil, for all water that falls as rain.

The sanitary effect of drainage.-Wet soils are sour. They are cold and uninviting. They are attractive neither to plants nor to bacteria. Since these are chiefly interested in the soil, their comfort and their wishes must be obeyed first. When both call for drainage, it should be provided.

Large tracts of land, now given over to swamps and marshes, and which are in poor sanitary condition, would. if clrained, be most useful areas for crop production and highly remunerative returns.

Not all soils need drainage.-You should not think that all soils will be improved by drainage: far from it. Considering the whole area of our country, the total area of land that needs drainage is small. We have vast areas of swamp lands and heavy clay lands, that certainly need drainage. But, on the other hand, many of our agricultural lands are naturally drained: they have open subsoils that readily allow surface soakings to find channels of escape.

You should be able to determine for yourself where drainage is necessary. II'hat has been said before in this chapter will indicate the type of lands that needs drainage, and that furnishes a fair diagnosis of drainage cases. If your land neels drainage, by all means provide it. I have known of many instances where a single crop has paid for the entire cost of land drainage. Often soils, more or less worthless, are male highly productive by a thorough system of tiling.

The kind of drain.- $\mathrm{We}$ have two forms of drains: open and covered. In case of the former, a simple channel or 
open ditch is cut. This furnishes a receptacle for surface and seepage waters, thereby relieving the land joining it of its surplus water.

The covered drain is made of tile, stone, wood, brush, and boards, and furnishes a satisfactory exit for soakage and seepage water. It is, by far, the most satisfactory kind of drain, although there are instances when an open drain is required. The objections to the open drain are: The constant attention that is required to keep it in order, to keep its banks from caving in, to keep out weeds that grow there abundantly, and to overcome the loss of so much land, which brings but small returns.

Open drains are often made with banks sloping outward. This admits less loss in waste, since grass affords pasture and protects the sides at the same time.

Under-drains: many kinds of material.-You may use quite a number of materials for constructing under-drains. The following kinds of materials frequently have been used: stone, brush; poles, boards, and tile. With one exception (tiles), these materials are out of date and now but seldom, if ever, used. They have served their purpose in their day but that was before the tile drain came. Now, compared with tiles, all other forms are inefficient and of little worth.

The stone drain has been used a great deal, even today it occasionally is in favor. When well constructed, it is lasting and efficient. But it costs too much. To make the stone drain properly, a wide trench is necessary, thus necessitating the moving of an immense amount of dirt. Besides, a tremendous quantity of stone is required, and the labor, for the entire work, makes the stone drain many times more costly than the tile drain. It seems to me it is a good deal better to use all stone accumulations for 
roads or bridges, and to call tiles into use for every form of drainage work.

It may be said, in passing, that brush, poles, and box drains, - in fact, any form of wooden drains,-are unsatisfactory, for the reason that these materials, sooner or later, rot and decay, thus requiring the entire operation to be repeated again.

Tiles: the perfect drain.-Tile drains are the cheapest that can be used. It would not be too much to say that drainage by tiles is the perfection of drainage. Thousands of practical tests in this country have demonstrated the value of tile drainage, for these reasons: (I) when once laid, a good tile drain will last for centuries; (2) the tile is out of reach of all cultivating tools; (3) tiles furnish the cheapest possible means of removing excess of water from the soil.

Tiles have become so common, there is no section in the country, to-day, where drainage is practiced, that they are not available and known. You will be making a mistake, most certainly, by employing any sort of drain other than tile.

IV $\mathrm{c}$ have many kinds of tiles. Many kinds. of many makes, and of many shapes and styles, all of which have been put upon the market. It is only necessary to say that the round tile is most in favor, and most generally accepted, wherever tile draining is performed. One of the advantages of the round style is the ease of laying it, and the ease of connecting it with the preceding tile.

Distance between drains.- The lay of the land, the fall, the nature of the soil, all come into prominence, and must be given due weight in laying out any system of land drainage.

I.ancls that are of heavy clay, for instance, necessarily will call for more tile than other lands that are more open 
and friable. Level lands, that naturally hold all the water that falls as rain, require a more perfect system of drainage than others that are relieved by surface washing.

The observing farmer readily will note the fields, or portions of fields, that call for land drainage. As soon as you get the system fixed in mind, start the work; and then let nothing come in the way that may prevent its completion.

Depth of drain.-The deeper that drains are placed, the larger the surface area they will drain. Judgment will be required in this case. Certainly, tile drains should scarcely, if ever, be placed at a depth of more than five feet-four feet, perhaps, being the limit. And there are also but few instances where tiles should be laid at a depth of less than two feet. The height of the outlet, of course, will be an all-controlling factor as to the depth at or near the outlet.

Roots of growing plants often play havoc with tile drains: by crowding into them to get air and moisture. Of course, they soon fill the drain and completely destroy it. Where tile drains run beneath trees of any kind, it is best to cement the joints, so as to completely prevent roots from gaining entrance.

In digging the ditch.-Complete sets of tools now go with tile draining. When the system has been determined and grade has been established, the next move is to dig the ditch or trench. The spading tool is best for the purpose: follow a line, throw the dirt on the most convenient side. After the ditch has been dug and the trench made ready for the tile, the bottom should be slightly rounded and thoroughly tested, so as to be on an absolutely perfect grade,-from two to six inches of fall for every one hundred feet.

The tiles are now laid, one after another, with closely 
fitting joints. Collars may be used, or any broken tile or stone, for covering the poorly fitting joints. When the tiles are laid, carefully fix fast the tile by banking either side with fine dirt, after which the trench may be quickly filled by hand or by plow.

Protect the outlet.-More than one farmer makes a mistake by not protecting the outlet of his tile drain. In the summer season, when no water is being moved, the tile drain becomes a pleasant abiding place, or often a shelter, for rats, rabbits, and other hole-seeking animals. It frequently happens that these animals get caught in the tile, and are unable to extricate themselves, thus dying in their underground retreat. Their remains offer a splendid lodgment for silt and clay, and soon completely fill up the drain, rendering it useless, and, to be repaired, a more or less costly undertaking.

A wire screen may be provided with little labor and with no expense, that will completely protect the outlet against these mishaps, and this will keep the chain serviceable for a time berond estimation.

While tile drainage, on a large scale, and for the entire country, is unnecessary, there still remains the fact that in every section of the country there are certain small areas that will be greatly improved, in fact, even remade, at little expense and cost. by under-clrainage through tiles. while, on the other hand, in some sections there are some soils so impervious that under-drainage is impracticable. 


\section{CHAPTER XVIII}

\section{SOIL WATER: HOW IT IS LOST; HOW IT MAY BE HELD}

The operation of loosening and stirring the soil usually is spoken of as tillage or cultivation. Heretofore four reasons have been advanced in support of tillage: it increases the root room for the plant; it admits air into the soil so that plant food may be more readily prepared; it secures oxygen for plant roots; and it destroys weeds.

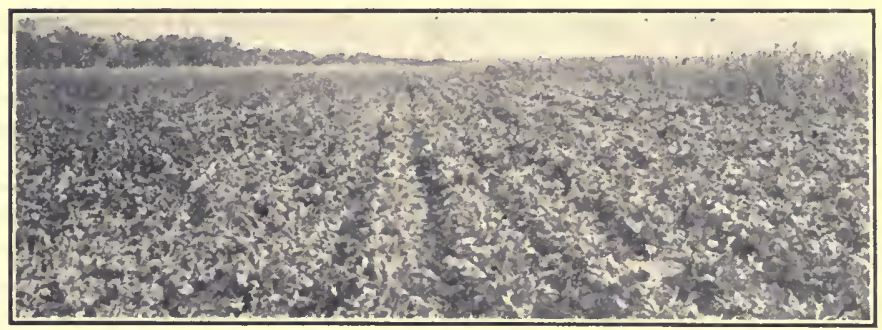

THE RESULT WHEN WATER IS SECURED AND HELD

The annual rainfall where these sugar beets were grown was but 20 inches

We must not overlook two other tillage operations that stand out prominently in any rational treatment of the soil. These are: the rainfall is enabled to enter the soil easily; the loss of water by evaporation is checked.

While each of these operations deserves careful attention, the last two are open to more gentle treatment and to more sensitive consideration than the operations previously described.

Transpiration: the exit through the leaves.-We have learned that roots gather moisture and carry it into the 
plant. This moisture, or water, conveys the soil nutriment with it to the plants. It then passes on up through the stems and leaves, to be exhaled, finally, through the leaves. The loss of water to the soil, by this means, is very large. For ordinary crops, from 300 to 500 pounds of water are required to produce one pound of dry matter.

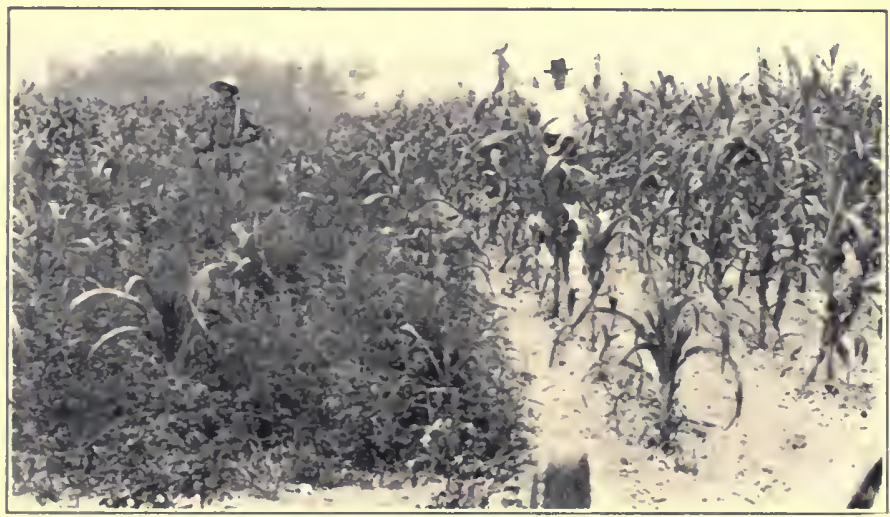

EFFECT OF CULTIVATION OF CORN CROP

Plot at right received ordinary good cultivation, and yielded 64 bushels of corn per acre. Plot at left received no cultivation, and yielded 4 bushels of corn per acre

It has been estimated that for average production of some common crops, the amount of water required for producing a single acre is as follows: Clover, 400 tons ; corn, 350 tons; grapes, 375 tons; oats, 375 tons; potatoes, 450 tons; wheat, 350 tons; and peas, 375 tons.

As the rainfall during the growing season is not sufficient as a means of supplying water to the crop, the water stored in the soil must be (lrawn upon considerably. This fact lays stress upon the importance of large water supplies in the soil, not as stagnant water, but as capillary 
water, closely identified with soil grains. It should be remembered that drainage applies to lands only that are fiat or naturally wet, and then mainly in the early part of the season, while the saving of moisture is the main factor in most soils.

Evaporation: drying out by sun and wind.-A second source of water loss is due to the action of the sun and wind, which cause water vapor to rise directly from the

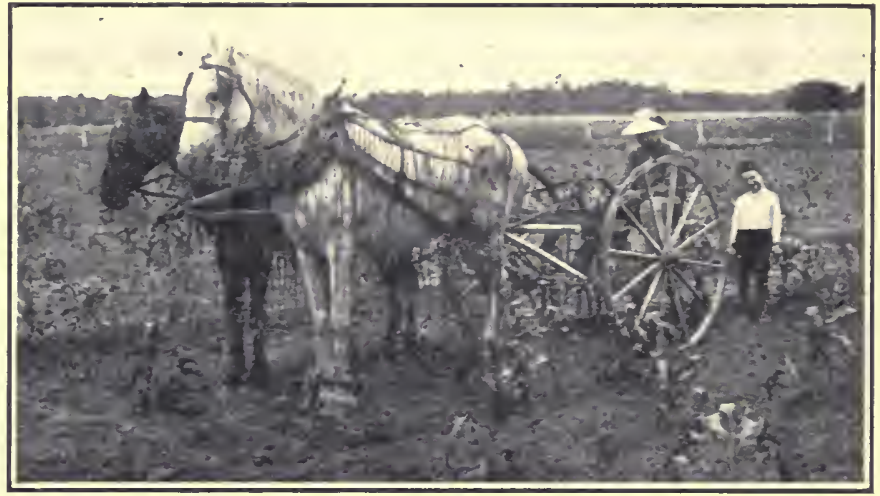

CULTIVATION CHECKS EVAPORATION

We cultivate to kill weeds, to conserve the moisture in the soil, and to render plant food available

surface of the soil. It matters not how much or how little moisture there is present in the soil; just the same, there is a constant loss, and notably so if the atmosphere is hot or dry. This escape of moisture is of prime importance to every farmer. It is needed in the soil; particularly is this true in dry seasons and during the summer months.

While it is true that every soil has a reserve store of water, it is just as true that this reserve supply often gets low, and especially is this so when the weather is hot 
and dry. Capillarity causes the trouble. We suppose that capillarity is an agent at work bringing water from lower depths up to roots for our good, only; but let us remember that this same force carries water higher than the root region, merely; it carries it up to the very top, where, when in contact with the surface, it is licked up by winds and atmosphere, and borne away beyond reach of soil or plant or man.

Cultivation checks evaporation.-It now becomes manifest that soils must be cultivated, not only to make them wholesome and attractive to seeds, and to kill weeds, but to cultivate them, also, to conserve this moisture-to check the loss occasioned by evaporation.

Naturally, a question arises: Does cultivation conserve moisture in the soil? In answer to this, let us consult the soil about the matter. In New Hampshire the observed differences between two plots are given below:

\begin{tabular}{|c|c|c|c|c|}
\hline & $\begin{array}{l}\text { ist Foot } \\
\text { Per cent. }\end{array}$ & $\begin{array}{l}\text { 2d Foot } \\
\text { Per cent. }\end{array}$ & $\begin{array}{l}{ }_{3} \mathrm{~d} \text { Font } \\
\text { Per cent. }\end{array}$ & $\begin{array}{l}\text { 4th Font } \\
\text { Per cern: }\end{array}$ \\
\hline Cultivated 3 inches deep.......... & $24 \cdot: 6$ & 24.82 & 23.53 & 22.95 \\
\hline No cultivation given.............. & 20.92 & $19 \cdot 3 \mathrm{I}$ & $\mathbf{r}_{9} \cdot t_{4}$ & 18.54 \\
\hline Difference................ & 3.24 & 5.51 & 3.89 & $4+1$ \\
\hline
\end{tabular}

Here is a saving of 352.64 tons of water per acre on the cultivated plot. Certainly, a saving of tremendous bearing during seasons of dry weather.

Water must be carried into the soil.- Is a preliminary step in conserving soil moisture, water must be admitterl to the soil. And right here is one of the spots where it is well to give close attention: you must get water into the soil before you can save it. Often the supply is short, and 
the least bit wasted acts as a handicap for the coming crop. Good farm practice aims to have and to hold the surface of the soil in such condition that the whole of the rain supply shall be received into it, and by gravitation drawn to the lower regions where the water stores are held and preserved.

Whenever the surface of the soil is tight and stiff and impervious, you may be sure that a good part of every rain will never get into the soil, but will be lost by surface drainage. And you must aim to get the rains of the entire year; not those that come during the growing season, only, but those of tall and winter and early spring, as well. Often the summer rains fall far short of the plants' demands, even though they are utilized in their entirety. Good crops often are produced when the rainfall, during the period of growth. is no more than a quarter of the quantity demanded and used by the plant. This is possible solely for the reason that there has been got into the soil a large part of the water that fell as rain earlier in the season-during the fall and winter months.

It is not stating the facts too loosely to say that in humid regions as much as 25 per cent. of the entire rainfall is lost to the soil, and for this reason: The streams get it, because the surface crust acts so slowly in absorbing the waters that come to it, the real amount obtained being much less than what it ought to be. And the same fault is applicable to semi-arid regions. While the loss here is not so great, it is only because the rainfall is less and the land more level and attractive to rain. A loss in this way of Io per cent.-a most conservative estimatemeans much, considering the fact that the average rainfall is but twenty inches annually.

It will be worth your while to remember that the water that runs off of the surface is not only lost to plants, but 
it washes also the surface and carries away with it plant food and a great deal of soil. It should be your aim to keep the soil loose and mellow on the surface, so that water may be absorbed freely and abundantly, and then

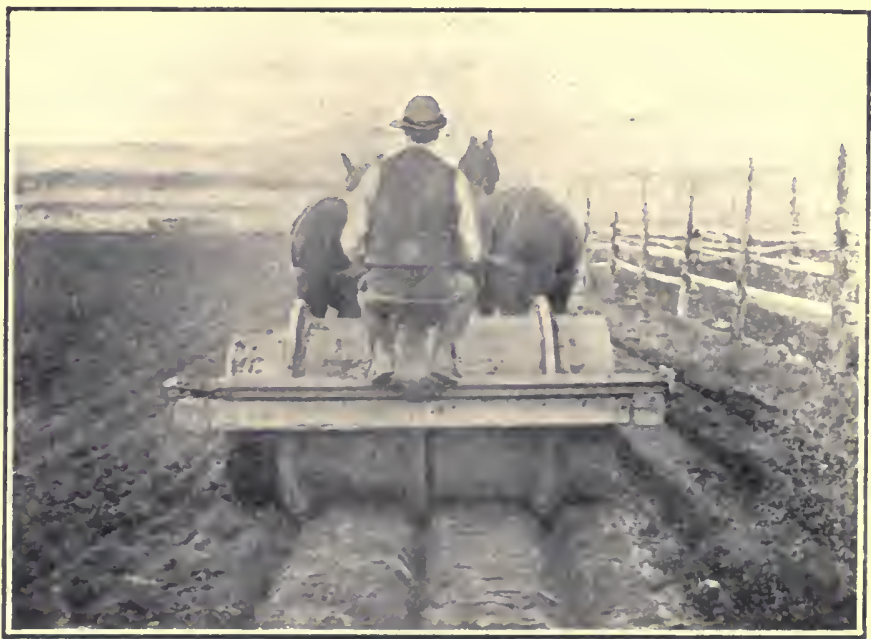

A HOME-MADE ROLLER

It does goud work as a roller, and leaves the surface of the soil in such a way that the water is prevented from escaping. This sort of roller must be run crosswise the slope and not with it

there will be enough to supply plants when the hot, dry part of summer comes.

The practical bearing is this: the surface of the soil must be kept loose and open so that as rapilly as rain falls it may be admitted into the upper soil. from whence it can work gradually down to the great storehouse beneath, to be held and preserved until later called into use.

Surface breaking a help.-This explains one helpful side of fall plowing: the stiff, hardened crust is broken 
and water freely enters, the ridges and hollows occasioned by the plowing operation, acting together, serve as tiny basins for catching and holding all little excesses, until the greater part of the contribution can be got into the soil. The entire turned portion of the soil further serves as a sponge for the time being, until the water just received can be given to the interspaces of the soil below. In North Carolina a test showed I 42 tons per acre of water more in a fall-plowed soil, than for similar soil plowed late in the spring.

The importance of this increase is readily seen: more water is stored in the soil and more is available for the crop later in the season at a time when the demands will be great and urgent. Similar results were obtained in New Hampshire. Out of fourteen determinations made, fall plowings showed larger water content in every case, the range being from 72 to 264 tons per acre above like soils that were plowed during the latter part of May.

A most frequent and conspicuous observation, especially during periods of drought, is this: Corn or cotton or other cultivated crop, day after day, week after week, contends against extreme heat and drought, without rain or prospect of rain; despairs not, though the soil is dry and hot; grows on and increases in size and strength, although but little, to pass at last beyond danger because rain has come, because the period of trial is over, because the earth is replenished again. Why is this so, when all about are fields of similar crops starved, ruined, if not dead? Simply because many months before water found admission into the soil, and there remained until the crucial test was made-water was demanded-the call was given, which, heeded, preserved the crop, and added fresh laurels to the crop and to its keeper.

It is stated that often if but a half inch more of water 
were in the soil, a destroyed, withered crop might have been saved.

These facts point to a general conclusion: fall plowing, because it offers an uneven, broken, open surface to the rain, enables water to enter the soil, and increases, in a marked degree, its water content.

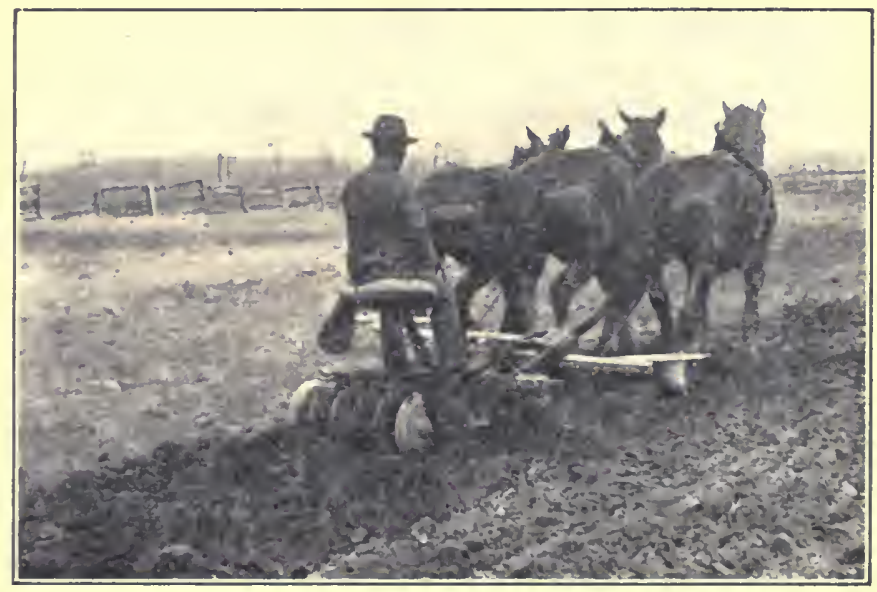

DISKING THE GROUND BEFORE PLOWING

A good practise, but not generally followed. It helps to make a fine seedbed, saves moisture, makes plowing easier and increases the crop

This same conclusion applies to early spring plowing and to disking, and for the same reason.

Iands that often suffer for water later in the season. may be helped much by rumning the disk before plowing time (as a part of land preparation for the seed). Olel corn lands, pea stubble, and worn-out pastures and meadows, especially, are helped ly this practice. When these are plowed a few weeks later. the soil will pulverize more readily, and it will be fitted for seeding with less effort 
and expense. I have come to appreciate the disk harrow most highly for this work. The labor and expense incidental to disking before plowing is more than met by the lessened amount of both at the time of preparation. And then the work is better done. A corn crop has been known to show its appreciation by yielding 8.6 bushels more per acre in favor of this sort of treatment.

Saving water by cultivation.-The work of the farmer is to induce water to enter the soil both in summer and winter. But it is more than this. He must save it, once it is secured. And now we come back to our original proposition: cultivation checks the water loss. Until you grasp this idea, until you come to a full realization of its force and importance, you will never be able to compel your soils to expend their fullest powers toward the production of maximum crops.

The principle of moisture-saving, briefly stated, is this : Water is carried from the water storehouse of the lover depths of the soil by capillarity. It rises in the soil from soil particle to soil particle, just as oil creeps up in the lamp-wick. It moves sidewise and diagonally and upward; it goes in the direction of the hardest pull.

But always, in the end, unless prevented by some obstacle-a dry mulch so acts-it finds the surface of the soil, at which point it passes into vapor and leaps into the atmosphere.

You have no reason to doubt this principle, for you have seen its evidence a thousand times. You have picked a board from the ground, or kicked a stone from its snug pocket, or taken leaves or grass or straw from the bed made, and you found that beneath either there was wetness; even a great deal, although on every side the surrounding soil was dry and hot.

There was but one way by which this could happen: by 
capillarity being at work, by water leaving the lower stores and rising upwards to the surface. Not to escape in this case, however, because the stone, or board, or vegetable matter, by acting as a blanket, kept the moving

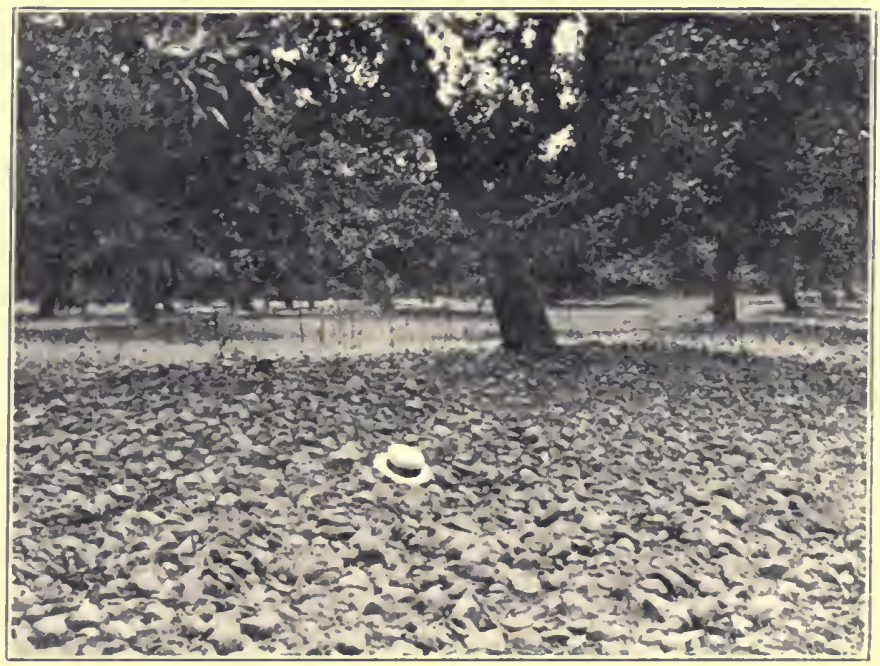

A STONE MULCH

Although many stones are present, the soil is fertile and produces profitable fruit. The stones serve as a mulch

water from rising higher and higher and up to the surface; and now no wind can come and take away the water just brought up.

This principle is now well established, and from it has been developed the practice of moisture-saving by providing a layer of loose, dry swil or mulch, from two to four inches deep, at the surface to serve as the blanket that shall prevent active moisture-loss: in other words, to check the loss by evaporation. 
While frequent stirring of the soil, during the growing season, and, especially, in the time of drought, tends to produce better crops than if this work is neglected, still, it is a wiser practice to begin the work of moisture con-

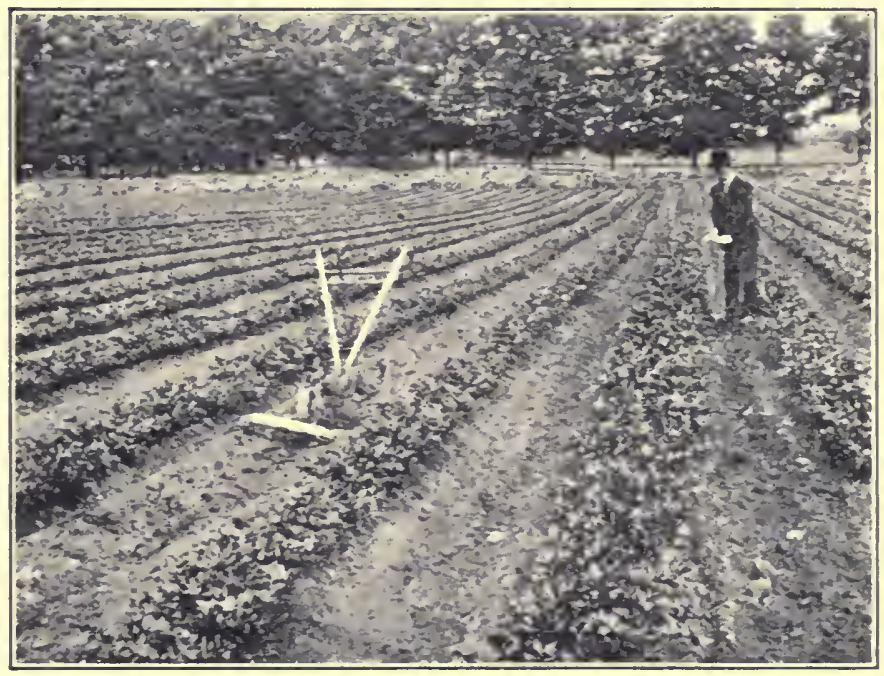

A GOOD MULCH

It is four inches deep and is doing its work

servation before the drought-period sets in. Hence, you must have much water admitted to the soil. You must keep it and preserve it until it is in greatest demand.

Keeping the surface crust broken and loose and mellow is the first step; it takes the water in. Conserving it, after it is stored, is the second step; it holds it for the plants.

Mulch-making: make it effective.-In periods of abundant rainfall, it matters little to you whether you stir your 
soil a half inch or four inches deep; for the time being, you are not concerned with the moisture content. But during dry weather you ought to be careful: you ought to interrupt and break the capillary tubes, that connect the surface and the immediate lower region, so that the escaping water may be kept within the smallest limits.

Now, as to the depth of the mulch: an inch is good if it is even and level and completely separated from the tubes below; if it provides an effective blanket over the surface of the soil. Even with so slight a mulch, the operation is beneficial, and quite a good deal more effective in retaining water than any form of broken tillage, although four or five inches deep. In ordinary practice, cultivating tools usually are run two or three inches deep, and hence a rather good mulch is thereby secured.

Experiments on this subject indicate the following:

I. That the water content of the soil is increased to a very appreciable extent, when the soil is evenly and uniformly stirred.

2. That the water content is increased in proportion to the depth and effectiveness of the mulch.

3. That the water content increases less rapidly as the depth of cultivation is increased beyond three inches.

4. That the water content is greater when cultivation is provided in a form of mulch, than by ridge culture or broken tillage. 


\section{CHAPTER XIX}

\section{DRY FARMING: A PROBLEM IN WATER CONSERVATION}

There is a vast empire in the western part of our country that was known once as the "Great American Desert." Here, in the early days, short grass grew and some other kinds of less nutritious food. In season buffaloes roamed and fed as best they could; and then the sturdy pioneer began his conquest.

He had examined the land and he wanted it. For the broad expanse and the fertile-looking soil tempted him as no land before had done: so he came and battled. The contest was severe; it was trying; it was exhausting.

"Before the people of the land

Had learned to grapple with strong hand

Soil culture problems, hearts were sore

And poverty hung 'round the door."

That was three decades ago when the West was new and young, when fat years brought hope and lean years despair and anguish. It occurred within an area occupying a strip of nearly three hundred million acres, extending from Canada on the north and down into Texas on the south, from the Rockies on the west to the Missouri (including the Dakotas and western Minnesota) on the East.

Into this region people flocked when it was opened to settlement. They knew not the land. They knew little of the soil. Little was known, in fact, at any place about soils. Plants were new to the section and untrained to the hardships of the new life. People came from other 
lands where all things were different, and the pioneer farmer could farm only as he had been accustomed: and he failed, for hot winds caught up the water and destroyed the crop.

In those early days water protection had not been thought of. The broad principle of water-saving had not

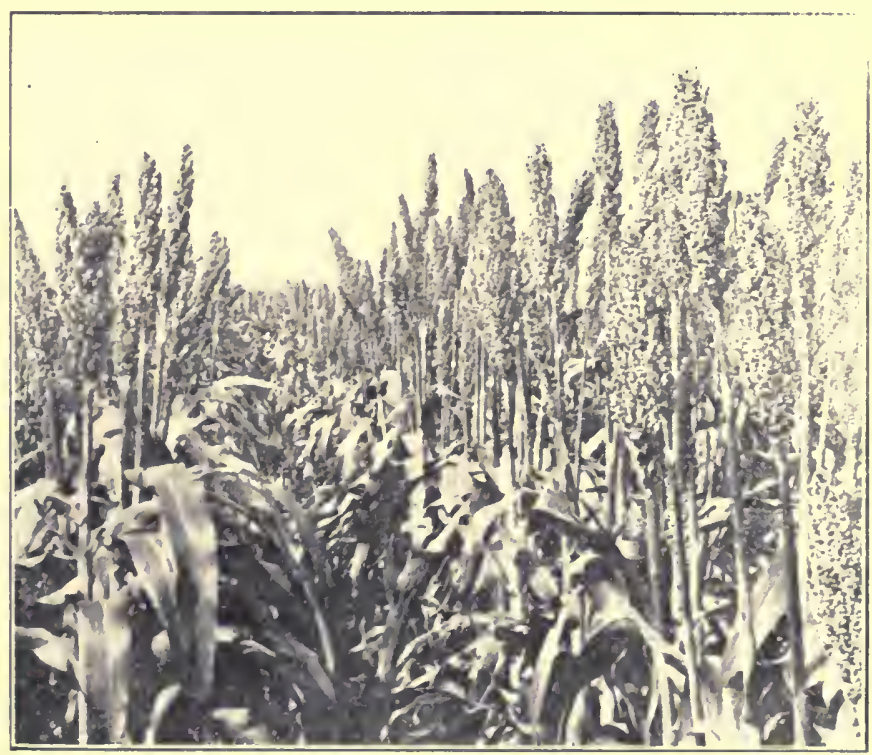

KAFFIR CORN

A wonderful crop for semi-arid regions

been put, as yet, into practice. It was not known. So lands were permitted to lose their moisture by evaporation for the reason that the farmer knew not the way by which moisture is male available for roots: of the absorption by the soil of winter rains and snow, of its remaining in the soil, protected and cared for by tillage 
tool and careful thought in management until the hot dry months, when it will be raised by capillary attraction to the surface, or better, raised to the point where the root is.

But the farmer knows about this now. Consequently, he pulverizes the top of the soil and he makes a mulch

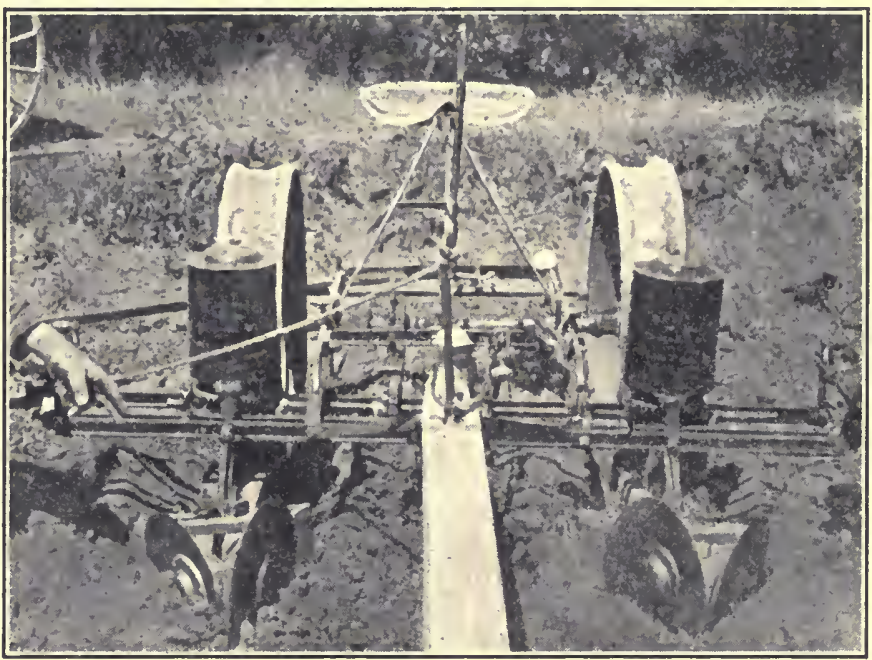

CORN PLANTER WITH DISK FURROW-OPENER ATTACHED

A tool that is very popular in dry-land sections

there, especially after a rain, so that the soil tubes or capillary tubes are broken at the top and the water covered in.

The meaning of dry farming.-Dry farming is not an attempt to grow crops without water. It is simply a contrast to irrigation and does connect crops with the minimum rainfall. The semi-arid belt has a rainfall of from fifteen to twenty-two or three inches, annually. If the soil be treated in such a manner that the greater part of 
this rainfall is carried into the soil and there stored, the crop can be saved and a bountiful harvest made, although there be little rain during the growing season.

Dry farming, or any system akin to water-saving, is nothing more than good farming. Its real meaning is good tillage; it means water-saving by good plowing and frequent, effective cultivation; it means crop rotation for its sanitary effect; it means humus for the soil for its many-sided benefits. Dry farming means especially these things: water is to be absorbed, water is to be saved, and plants are to be adapted to their mode of life.

It is a fact beyond controversy that the average farmer rarely comprehends just what land management means. He plows, of course, but he usually stops there. Mere plowing may mean tremendous moisture loss. unless cultivation be given-the mulch-making kind-so that the capillary tubes of the top and under soil may be disconnected, that the water in the reservoir beneath may not get out into the atmosphere above.

Since the soil has been studied in the laboratory and field, many of the secrets, heretofore hidden and unintelligible, have been revealed. This revelation tells us that many old methods employed in the management of lands-of tillage and of cultivation-are poor methods, indeed. Good farming aims to hold onto the best of the old methods and to adopt every good iclea or method that is provided and tried.

Managing stubble lands.-Now, in the summer time we find the greatest diffieulty, and especially is this true of the water supply. Weerls, grass, and growing crops are at work pumping water out of the soil The winds lick water from the surface as fast as it eomes to the top. The air, so frepuently hot and thirsty, pulls into its kingdom every bit of vapor or moisture that peeps above the sur- 
face of the earth. Between them, water is sent rapidly and constantly into the atmosphere, away from the soil.

If your lands require water protection, deny it not. Maybe your lands are in stubble, perhaps in wheat or in oats. You wait for weeks or months before you plow and prepare the seed-bed. But now it is fashionable (and good practice) to treat the land largely from the standpoint of moisture control, and at least give water more

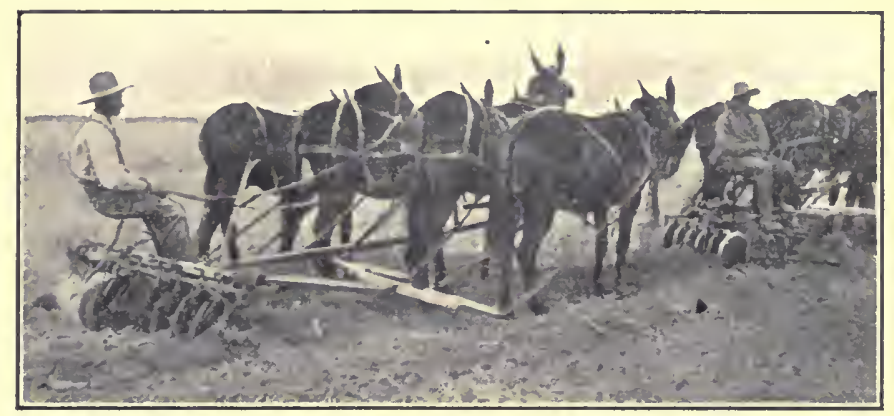

DOUBLE-DISKING THE LAND

This sort of tillage pays. Water is both admitted to the soil and held

consideration than its previous allotment. The old plan gave a minimum amount of rain to the soil and took a maximum amount of water out of the soil. The new plan supplies a maximum quantity of rain to the soil and allows a minimum quantity only to find its escape.

Have you ever tried disking the stubble land, tried disking just after harvest? You get these results: water is stored and held; and when you plow a little later, you find that the plow works differently to what it has been doing heretofore. Now it is more to your liking: it prepares the land; it leaves it mellow and fine and open; it gives the land the ideal tilth. 
Disking has contributed largely to this happy result. When stubble lands are to pass the fall and winter without use-no crop before spring-disking often will provide all the tillage that is needed. A few trials will tell you. Indeed, you may find by so doing that you may add many bushels to your next year's crop. If drought is not infrequent in your vicinity, water storing is a problem with you, and it is good business to plan your tillage operatrons in such manner that water may be admitted with

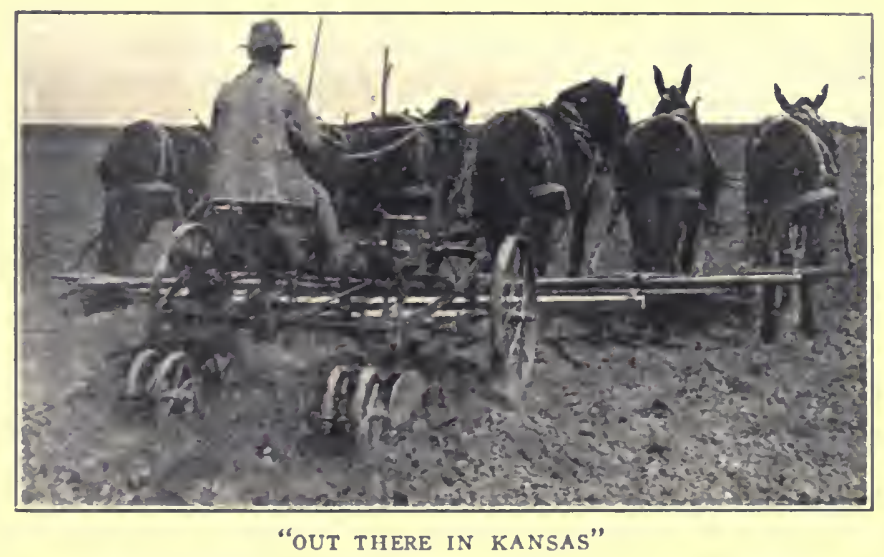

Planting corn with six-horse Lister

ease and held without difficulty during the whole time your land is idle or at rest.

What to do with plowed lands.-Suppose you have disked your land or have fall-plowed it-what is the next step? As I see it, the next step is just like unto the first: it is continued preparation. Just this: use the disk as soon as weather conclitions permit in the spring. You are to plow, of course,-at least, you are to plow your stiff lands: but use the disk (in the West the lister may be 
wisely used for this purpose), that the winter crust may be broken so as to admit freely the spring rains. Then it will pay. It adds to the cost, I know, but you put the water-immense stores of it-into the reservoir below that will be at your service and command when the call of the summer has come.

This sort of intensive culture may not be needed if rains are abundant when the growing season is in progress; still, too little water enters. Even in wet seasons crops

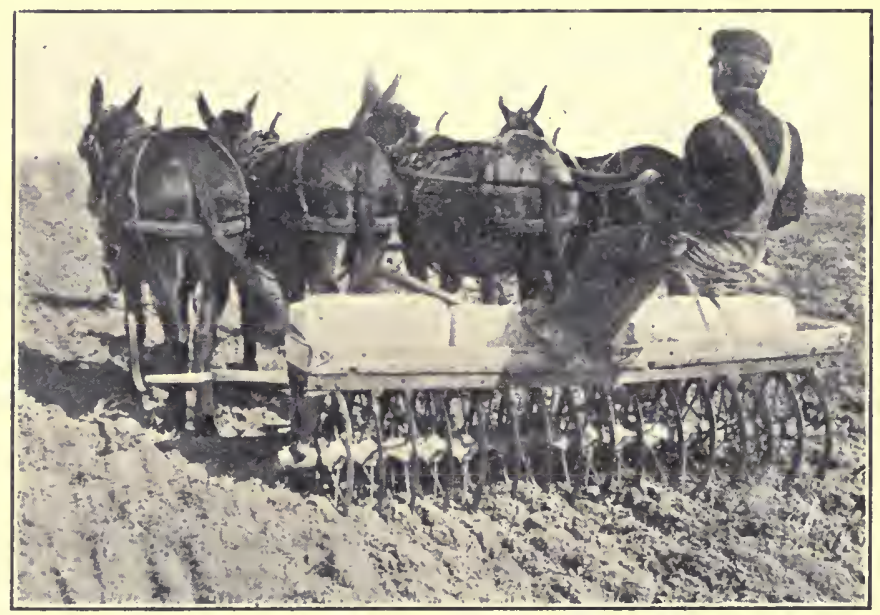

SUB-SURFACE PACKING

This tool firms the soil, breaks the clods and levels the surface

suffer for water-at least, at times, and a goodly supply on hand may not be amiss. And, after all, water sinks into the soil rather slowly, at best, and a summer rain may never get down where the roots grow. Summer rains, by starting water upwards and by destroying the mulch, may assist even in drying the land.

Sub-surface packing: a dry-farming tool.-You may 
have water in the soil, but which works to the top so slowly, newly planted seeds may get too little and so will not sprout and develop. If you are so situated that such is the case, you will find that packing the land will assist in correcting the difficulty. Just press the soil grains together, and the capillary flow will be improved: it will work.

A new tool-the sub-surface packer-lias come into use to do just this thing. It is a sort of roller-a bevel wheel roller-that cuts like a lisk and compacts like a roller. Its manner of construction secures packing of the soil just beneath the surface and not at the top. As moisture is drawn to the surfice, it stops where the seed lay, since the surface is broken by the pucteres and is left as a mulch on! hence the surface loss is: minimized. Py packin: the upper layer of the soi: a free movement of the soil moisture is allowed. This moisture is concentrated at a point just beneath the surface and at a point where needed by seed and new spreading roots.

The firm stratum thus made ly the surface pack-

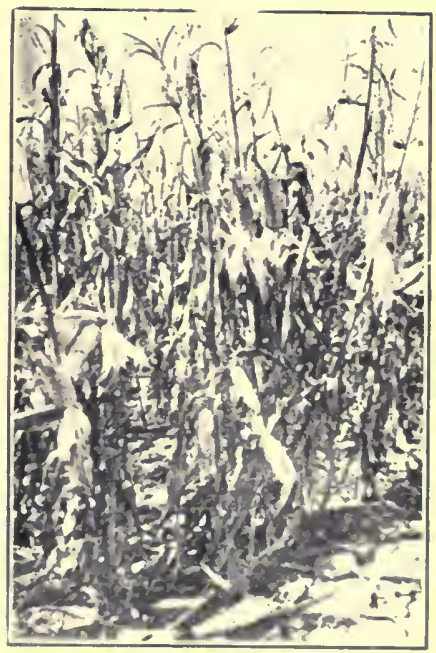

DRY-LAND FARMING

$A$ vield of fis bushels per acre, with a raintall of but 20 inches annually er brings up the water, but serves as a resistance in its movement out of the soil. 'This culural operation, combined with the mulch un top, offers a fairly effective 
trap and assists in preventing water loss. Extreme treatment like this, perhaps, is necessary only in regions where the water loss is large and the rainfall small. IV'lile the sub-surface packer is peculiarly a semi-arid tool, it cloulstless will, in time, secure favor in humid lands, also.

Water-saving: a universal problem.-If it were possible to estimate the shortage of crops due to lack of water in arid or humid regions, the figures would surprise even the most faithful of the creed of water-saving. While the problem is immense, the solution is easy. I doubt if attention can be applied in any direction that will bring so great and so lasting returns as that given to water-conservation: a problem that includes every phase of soil management from the time water is taken into the soil until it is used by the growing crop.

In the past, we have given attention largely to the chemical side of soils: to that side having to do with plant food. But recent study brings us to a realization that water is important: just as important as is plant food. Hence, no effort in soil management will bring so good results as will a conscientious effort directed along the line of moisture control. 


\section{CHAPTER XX}

\section{TILLAGE TOOLS: WHAT THEY ARE FOR; HOW TO USE THEM}

One of the most expensive things a man can do is to move dirt.

No tool has ever been invented that moves so great quantities of soil for so little money as the plow. No farm implement is more in use, nor is any more essential, yet Professor Roberts declares that in America plowing is the least understoor and the most imperfectly performed operation in connection with our preparation of land for crops.

We know how to plow, but how few of us really know when and why to plow. The only reasons why people used to plow were to get crops in and to kill the weeds. It is no wonder to me that at one time people hated to plow. With primitive tools it was hard work; and it, too, was slow work.

The first plow was a sharpened stick. - The first plow was the sharpened stick. liut man is lazy: he soon abandons this most primitive of all forms of tillage, selects a forked stick, ties it to the horns of a bull, and makes the animal do most of the work.

Thousands of plows have been invented since this early type, but there is no change in the principle. The motive power has changerl: the long end of the forked stick has been succeded by a beam of funished word or steel: the short end has been metamorphosed into a chilled steel point and moldlonarel the rough hand knot has been supplanted by curving liandles or a driver's seat; but for all 
these improvements, there has been no radical change in the tool.

The work the modern plow should do.-Now, what should this modern plow, evolved from the crooked stick, do for the land? Ilow shall a man know when he has a good plow, how shall he know when he is doing capital

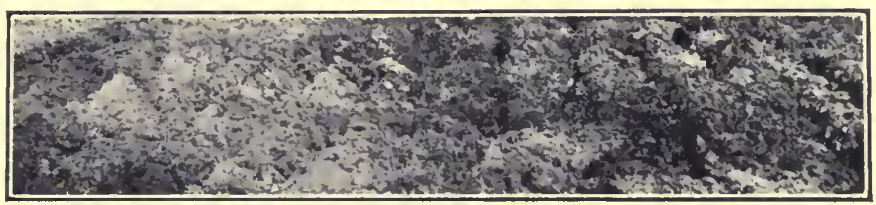

IDEAL PLOWING

The soil is pulverized and all rubbish is buried. The right sort of seed-bed can be made now with ease

work? In the first place, the effective plow turns the land; the furrow slice is laid entirely over, or it is set up well on edge. In either case, it must cover manure, trash, or green crops.

In the second place, the plow should go deep into the

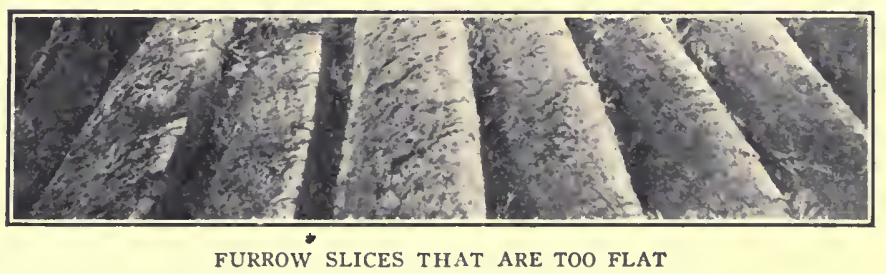

While all herbage is covered, the soil is pulverized poorly. It is not so good as it looks

ground. This for two reasons: deep plowing, as stated heretofore, enables the soil to drink in and to hold more water against the time of drought. Deep plowing gives plant roots a wider pasture. 
In the third place, the effective plow must pulverize the furrow slice turned out. Turning the land is not enough; the soil must be broken, fined, and mellowed. We get these results by means of the sharp, bold curve that is given the moldboard. A plow that does not thoroughly pulverize the soil is a poor plow. It may make a handsome furrow, cover the ground well, plunge far into the ground, and still do poor plowing: unless it leaves the soil in so friable a condition that the other tillage tools can easily and economically do their part, it has fallen short of its duty.

Aim to get a furrow slice that is set well on edge, with a snap as it comes from the moldboard. This is the sort that the harrow uses best for completing the bed for seeds.

In addition to plowing in order to get a pulverized, deep, warm, moisture-holding plant hed. we must plow with a view to bettering the physical condition of the land. Hence, we should aim to get deep and uniform plowing clone in every fielcl.

An example of poor plowing.-Recently, I stousl at one place in a newly plowed field and connted fifty-eight places left unplowed. because the plowman had carelessly let his plow jump ont of the arouncl. This was not only poor plowing. but it showed that the plow-holder was ignorant of one of the first principles of tillage-namely, that plowing releases plant foorl stores in the soil. The places skipped by the plow, then. even if the seculs germinated in them. would have less plant form to furnish the crops on them, than the plowerl portions on the same field have. Why? Because the ronts set in another manner all the products in the storelouse.

The subsoil plow: the work it has to do. - In this work of rendering plant food available, the subsoil plow is espe- 
cially valuable. Its power to go deep opens new pastures to plant roots. The closely packed soil, untouched by other plows, is made fertile and friable. The subsoil plow brings this new zone, with its accumulated reserve of plant nutrients, within reach of the plants. It almost adds a new farm to the old one.

Subsoiling is an expensive process, yet in no other way can the hard floor under the top soil-a floor that plant

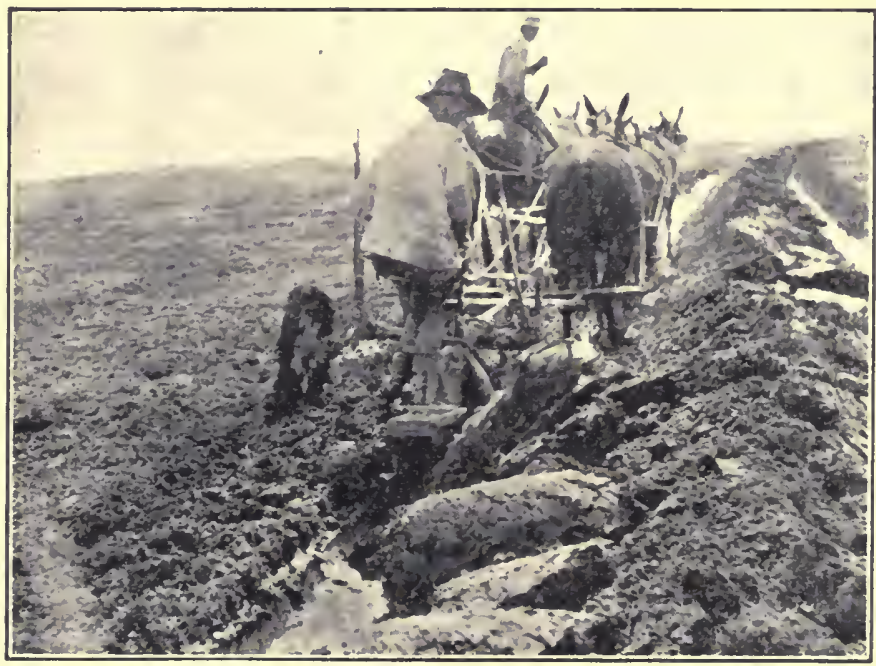

PLOWING LEVEES FOR RICE

roots vainly seek to penetrate; a floor that turns the rain above it, and imprisons the food beneath it-in no other way can this floor be broken through. In no other way can the sun, air, and moisture be admitted to the depths below, where they are needed to fit the soil for an ideal plant home. In no other way can undissolved plant food, held fast in the dark compounds below, be liberated. 
Of course, all lands do not need to be subsoiled. Your own judgment will determine this for you. In many cases, plants will do the work, provided the hard pan is neither too thick nor too hard. The cow pea, the soy bean, and the clover plant are all good subsoilers. Have you ever tried them? Here is just the point: you better have one acre properly prepared and tilled, than several imperfectly cultivated. Your returns will be greater, for all the first expense of this sort of tillage, and of the seed and labor, is saved by getting your required crop from fewer acres.

Long, long ago Poor Richard said, "Plow deep, while the sluggards sleep"; and, although Richard would have been sadly puzzled to give the reason for this aphorism, he was right both from an economical and a cultural point of view. You will agree with me that proper plowing is essential to prosperous farming. The farmer gives less thought to the kind of plow that he shall use, than the carriage in which he rides. It is a sad thing to see, but he does just that thing.

The one-horse plow: a tool of the past.-In many parts of the country we find one-horse plows in extensive use, yet none of the aims of tillage are attained by the shallowrunning, one-horse plow. Nor can this tool be defended on the ground of economy. The two-horse walking plow not only cloes farm work better, but it does as much work as two one-horse plows, and saves the labor of one man.

The two-horse or the four-horse walking plow ought soon find a place on even the smallest farm. The sooner you send the one-horse plow to the musemm, along with the crosked plows and the hand-spinning frames, the better it will be for your farm: the hetter it will he for you.

Some other kinds of plows. - The sulky plow is coming into favor, although somewhat gratually. On level land 


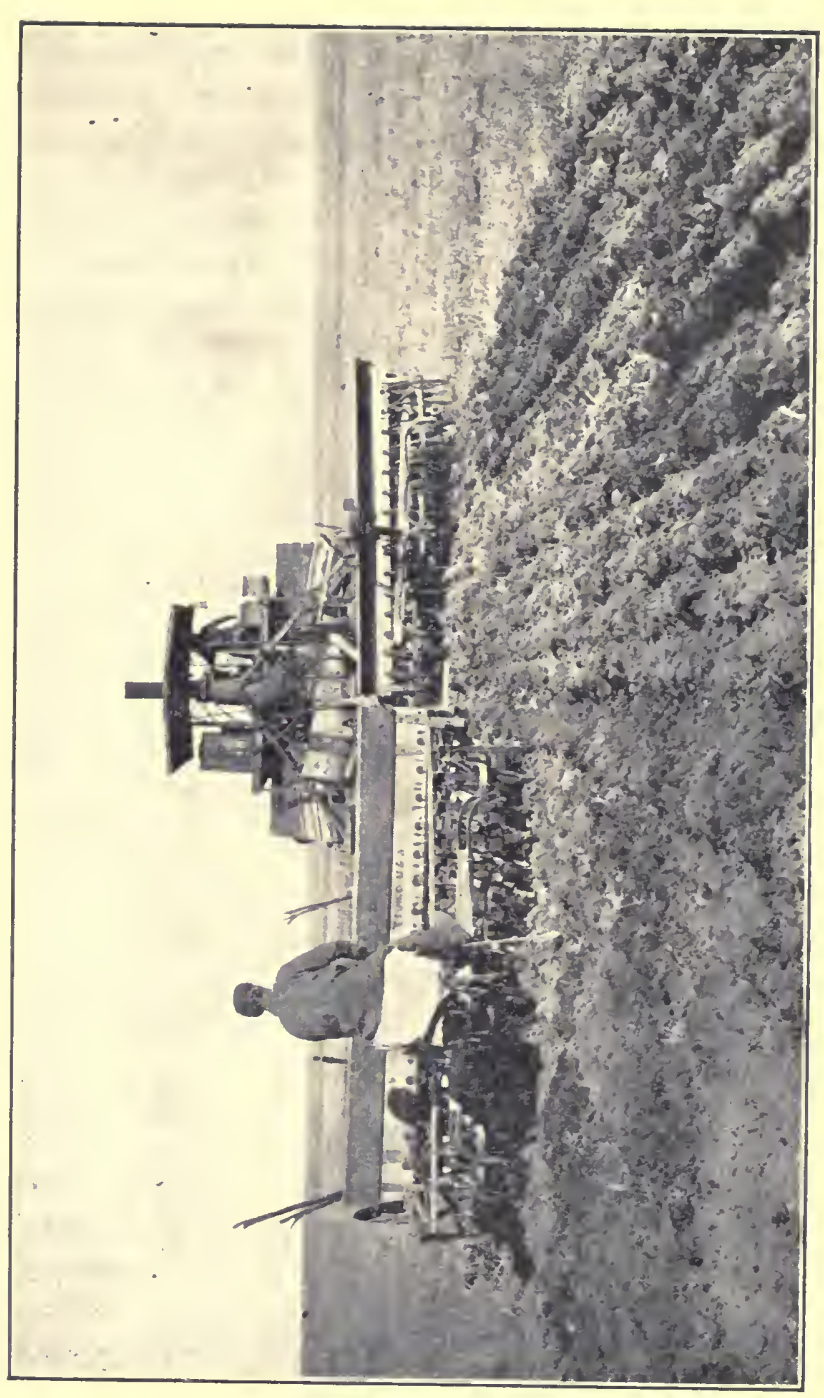

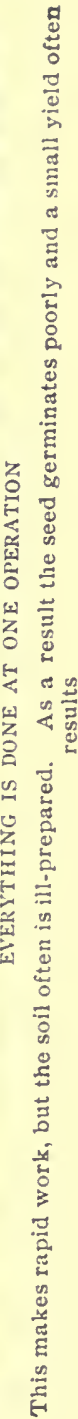


there is little difference in draft between the walking plow and the sulky plow. The draft of the sulky is slightly increased in going up hill; hence, the wheel plow is at a disadrantage, somewhat, on hilly land, but on level land it is to be preferred because it pulls no harder and does its work with care, certainty, and accuracy.

'The disk plow is fast coming into favor. It pulverizes well, and covers trash in an effective manner. It, however, cannot be used, practically, in stony land. This kind of plow is well adapted to hard, gummy soils, in which it is difficult to keep the required depth with the moldboard plow, and it is preferable to the latter in breaking hard-pan and hard-baked topsoils. This tool is generally satisfactory where deep plowing is to be done. alway's leaving the soil in a loose, broken condition. This plow is now made for horses and for steam.

The gang plow is intended for large areas. It requires the employment of several horses or of an engine, but a single man can operate it, and perhaps (lo better work than he could, if guiding a single plew hy hand. 'This sort of plow finds its place on extensive farms that are level and free from rock. lederes, and ditches. It is used largely in the IV est. but there is no reasem, howerer. why small steam plows should not le used to good allantage in every section of the comtry. Ciencrally speaking, steam-plowed land is plowed no deeper than that done ly horse power, lut steam does the work more cenmmically.

Every plow that has heen made, and has stom the test of time, is built on the principle of a domble wedge-one force of the wedge acting in a vertical, the wher in a horizontal plane. The plows wi the future will doubtless be built on a similar plan, lut the constant aim will be to make them penetrate to a sreater (lepth, and pulverize the soil more fully. The nearer the plow achieves this 
end, the greater will be the soil reservoir for holding water and soluble plant food.

The tools of preparation: their work.-The harrow follows the plow. You need this tool in connection with the roller, to complete the pulverization of the soil, begun by

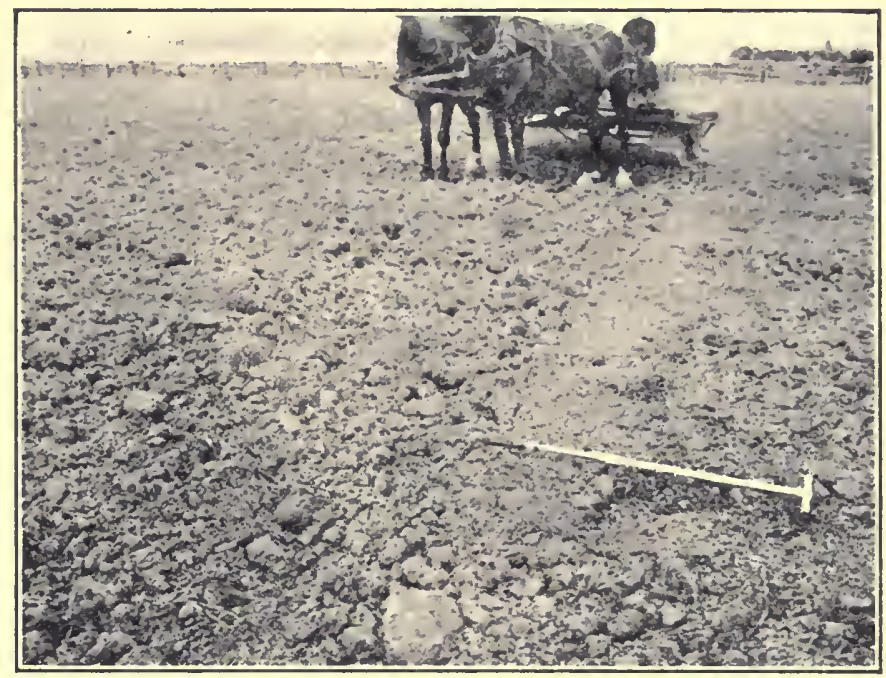

WHERE ROLLING DOES LITTLE GOOD

The clods are too hard-and so the work is not done effectively. Clay lands must be worked at just the right time to get the desired results

the plow. Both of these tools mellow the soil and push the particles nearer to one another. You have observed that the cloddy spots found in a fertile field make a poor harvest. In these places the bad condition of the soil excludes moisture and pens in plant food, hence this lack of fruitfulness.

The harrow and roller will correct this trouble. You cannot be too painstaking, when it comes to harrowing. 
A field may look well after a harrow has gone over it, but this does not necessarily mean that the work has been done well. For this reason, you should always examine carefully to see whetler the soil has been uniformly pulverized, and the particles pressed in close contiguity.

While few men catch the spirit of plowing, a still less number catch the spirit of harrowing. The harrow is the tool to complete disintegration and pulverization. It should go three, four, or even five inches into the soil. The harrow teeth should go down well below the surface, and work among clods and lumps; they should either break all clods and lumps, or bring them to the surface where they can be ground and crumbled by subsequent tillage.

A field is never well harrowed until the interstices between the coarser particles are filled with a sifting in of the finer particles. When this has been accomplished, the seeds have a perfect chance to sprout and grow; the soil is well fitted to take care of its water supply.

One kind of harrow is not enough: it will not do for all seasons, nor for all soils. Here are the things the harrow must do: it must smooth. cut, level, sparle. pulverize, and compact. No harrow can do all these, hence. you will need different kinds to do all the work involved in harrowing well and effectively.

The fine-tooth, smoothing harrow should have a place on every farm. It levels and disintegrates, and it comes in handily for intertillage: it does splendidly on corn and cotton land after planting is done.

The spring-tooth larrow should be lade as it comes in nicely where you have leveling and smoothing to do, or where a heavy rain has compacted the soil too hard for seeding purposes.

In addition to these, you should liave a disk or cut-away 
harrow. You will find it very valuable-in fact, indispensable-for many kinds of farm work. Such a harrow takes the place of the plow in seeding wheat or rye, after corn or cotton or cow peas or potatoes. The rolling disk cuts and turns and pulverizes, and thus does the work of a plow, although it does not go so deeply. But since you want a compact soil, excepting the top, this becomes the very implement for your work. Fields that have just

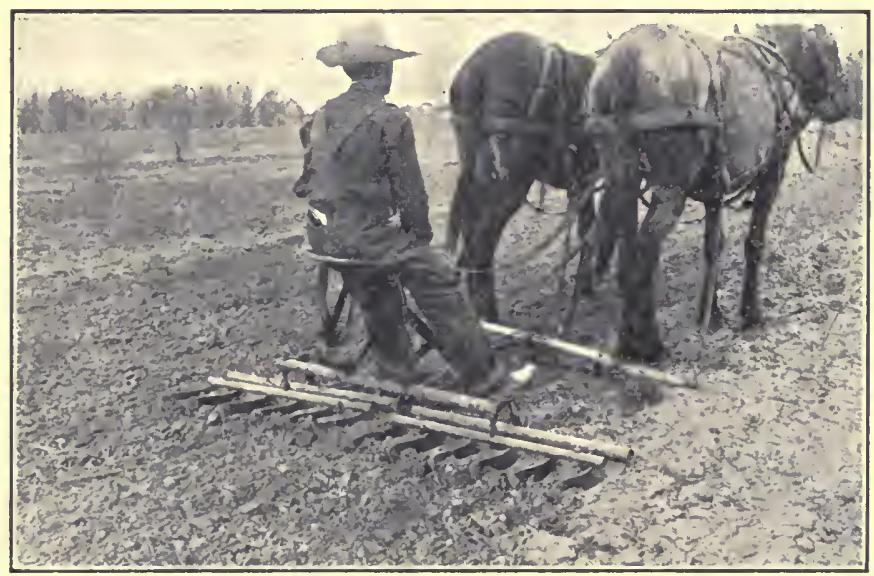

THE ACME HARROW

A splendid mulch maker, weed killer and all 'round cultivator. Note the cracked and crusted soil at right, and after-treatment at left

been disked and then crossed with a spring-tooth harrow are usually left smooth and mellow, and in a fine condition for the seeding tools.

The disk harrow is an excellent tool to use immediately after the harvest as a means of opening the soils to catch summer rains, and of conserving the moisture already present in the soil. In our dryer sections, especially in semi-arid regions, this plan of soil treatment is coming 
into practice, and is to be commended. If you find clods on top, the wooden drag or roller will be the next implement to use. The wooden drag grinds the clods and lumps; and is also a good implement for leveling purposes. The roller is primarily a crushing and compacting

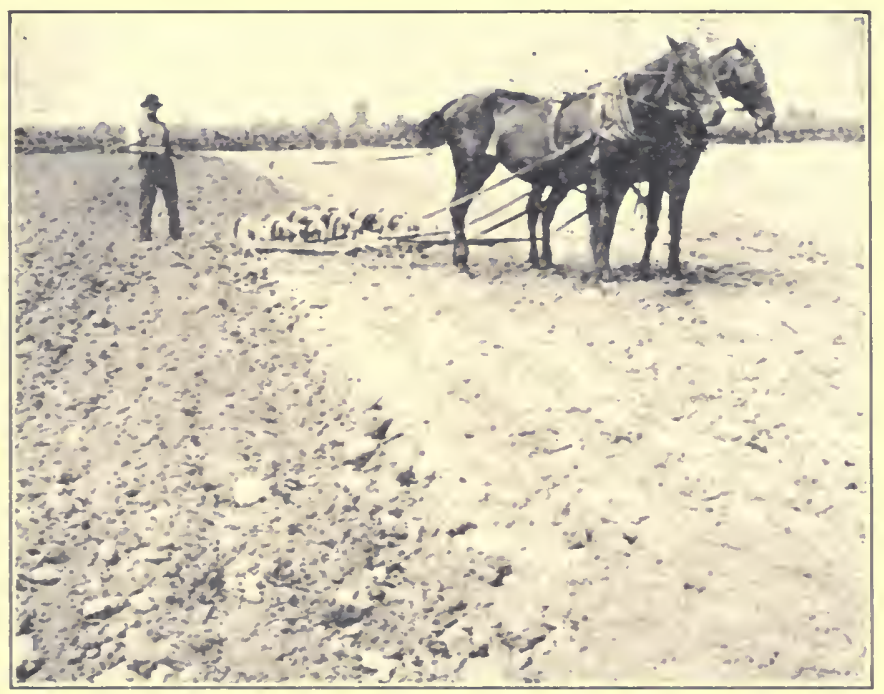

A STEP IN SUIL PREP.IRATION

The effect of the spring-tonth harrow, after the roller, is shown in the picture.

Thus tool is spiendid for lusenung hard soils, for leveling and tor stiril..g

tool. While it is effective as a crusher, it drives the dry. hard clods into the suriace soil.

You will find the roller most desirable during dry seasons for compacting the soil so that capillarity may he restored. and mosture from the great reservote down in the seril be drawn up to the sceds and routs. This, however, may prove harmful. fur you may induce a tox) rapid evaporation, and thus destroy your reares -mplyly. You 
can minimize this harmful effect by using a smoothing harrow, a few days after the roller. Fortunate is the farmer who becomes a believer in the practice of making the soil firm for all seeds and plants.

Compacting the soil increases water content.-The market gardener has lead the way here. Just note how he uses his feet to accomplish this very purpose: he knows that it pays-in fact, that it is clearly necessary to make firm soil about the newly planted plants or seeds. This is important in dry, hot weather in loose, poor soils. The farm roller and gardener's feet both accomplish the same work. Both compact the soil; start the water in the soil below on an upward course that brings it to the seeds and roots that need it.

When this has been accomplished, a smoothing harrow, with its little teeth, should be run over the land so as to break off the tops of the capillary tubes; and thus make a mulch of the top soil, and check the evaporation of the soil water.

The cultivating tools involved in the tillage of the soil answer three purposes: they kill weeds; they provide a much-needed mulch, especially in dry climates, so as to preserve moisture; and they release plant food. The old one-shovel plow is fast giving way to the shallow cultivator with several shovels. We no longer expect to use intercultural tools for preparing the soil for root development: we do that now at seeding time. 


\section{CHAPTER XXI}

\section{THE CULTIVATION OF CROPS: THE TOOLS AND THE PURPOSES}

The cultivating tools involved in the interculture of crops serve three purposes: they release plant food; they kill weeds; and they provide a mulch so as to prevent the loss of soil water. The modern idea is to cultivate the soil in a manner that a shallow and mellow mulch will be made, the work being especially designed for the purpose of water-saving. Hence, the old shovel plow that went deep into the soil has been replaced almost entirely by modern tools that never reach the lower depths of the soil nor trouch the roots of the plant. The onehorse plow, now used so much in the cotton and corn fields of the South, is likewise losing its popularity and is loeingr succeederl by more shallowcultivating tools with several shovels. It is poor

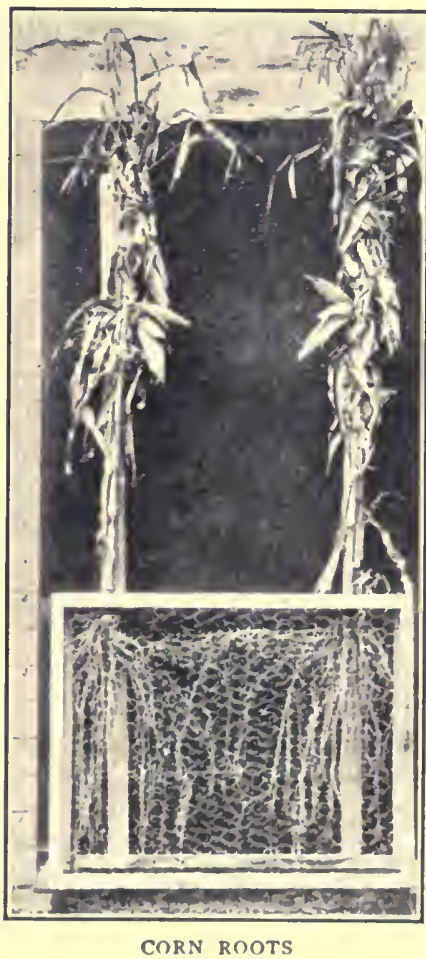

They occupy the entire space be. tween the rows to within a few inches of the surface. Do you wonder why deep cultivation injures the crop? 
business to use interculture tools to prepare the soil for root development-that injures the crop; and such work should be done before seeding time.

Interculture tools: the weeder and many-shovel cultivators.-The weeder ranks first in popularity as a tool for beginning the work of cultivation. It runs shallow; its many teeth destroy the tiny weeds just peeping through

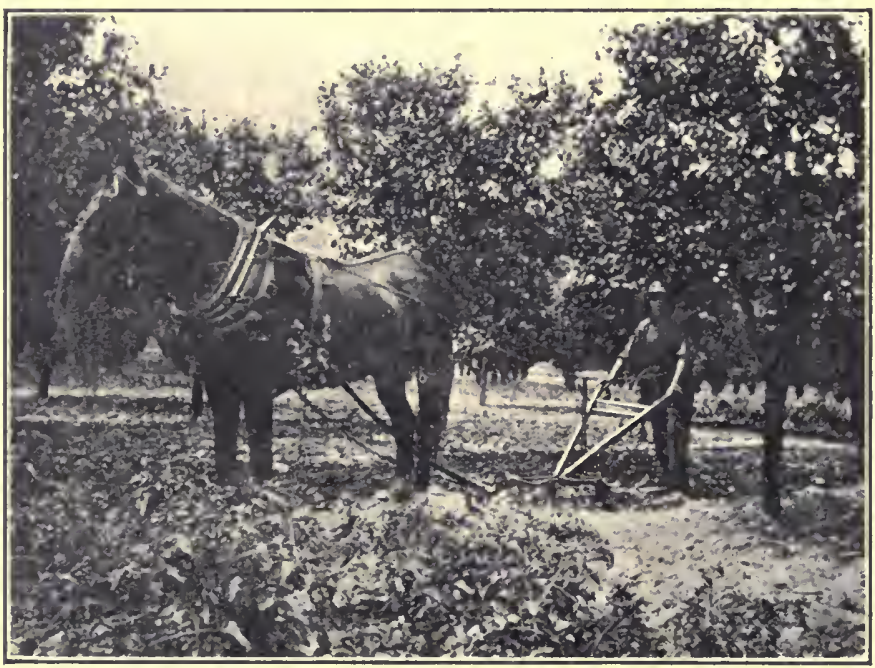

CULTIVATING THE ORCHARD

Orchards respond often to cultivation as generously as corn fields

the ground; its complete soil-stirring makes a fairly effective mulch. The weeder can be used two or three times in cultivating most crops, especially if soil is loose and if it is to be followed by some other kind of cultivator. If you do not have the weeder, you can use the smoothing harrow to almost equal advantage when the plants are short and small. After the crop is somewhat 
grown, the weeder is impracticable for further use; and the many-shovel cultivator takes its place.

All sorts of cultivators are available: they are of many makes and of many kinds. Perhaps the most numerous sorts are the two-horse cultivators-walking and ridingthat permit one man to do the work of two men with single cultivators, doing the work just as well and with less fatigue. Double cultivitors are made with shovels, disks, and spring tecth. Shovels and spring teeth are most in use, although for some kinds of work the disks are to be preferred. The latter are especially good to cut and cover in weedy land. Their fault lies in the ridges they make. It is level culture that you want, and this is difficult to get with a disk cultivator unless conclitions are ideal. In wet lands, cultivation is resorted to as a drainage operation; in this case, the disk cultivator is the best tool you can use.

Cultivation rids the land of weeds.-Lands must be kept free from weeds, else the best results will never be possible. This is shown by a test at the New Hampshire Experiment Station. The plan of the experiment and yields are shown in the table:

\begin{tabular}{|c|c|c|}
\hline Plot & Treatment Given & $\begin{array}{l}\text { Bushels of } \\
\text { shelled corn }\end{array}$ \\
\hline $\mathbf{z}$ & 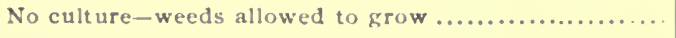 & 17 \\
\hline 2 & 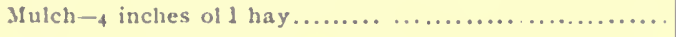 & 56 \\
\hline 3 & 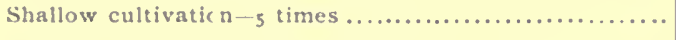 & 80 \\
\hline 4 & Shallow cultivation -86 times .... & 82 \\
\hline 5 & 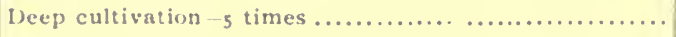 & 74 \\
\hline
\end{tabular}

Much of the story of cultivation is told in these restilts. The need of culture is recognized at a glance. When 


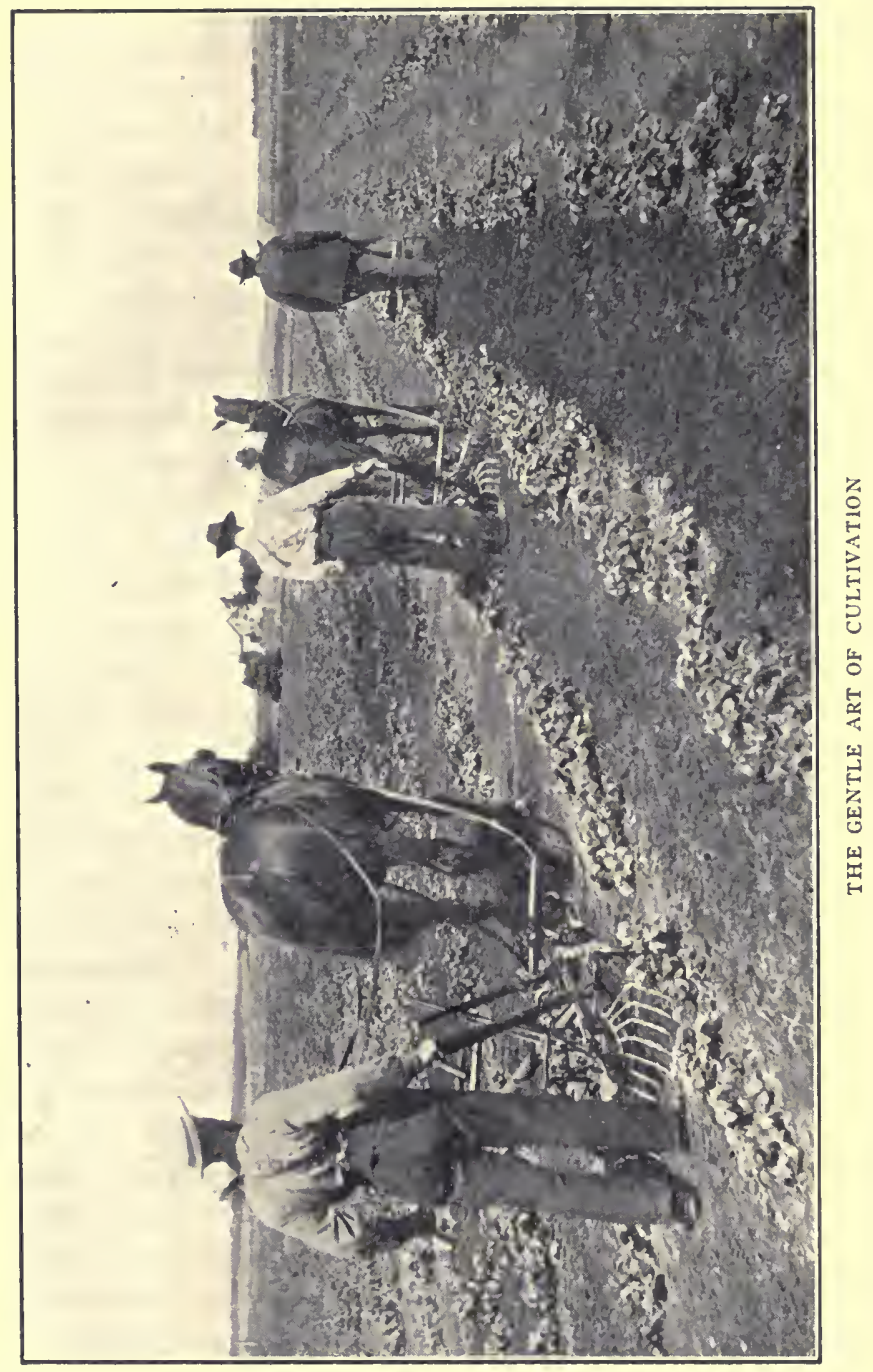


weeds are allowed to grow, they poison the land, steal plant food, rob the soil of its water, and shade the earth. It may cost something in labor and effort to keep weeds away, but it costs a great deal more to let them grow.

We find several other interesting facts in these results. The four inches of hay, used as a mulch, did not secure the best yield. An abundance of water was held in the soil; but the soil was cold-too cold-and the crop was cut short.

The dry earth mulch is better. It is better than a vegetable mulch, when either deep or shallow culture is given. It is a great deal less expensive, also. And it is effective ; it keeps the water in the soil.

You will note but a slight difference between the two plots that were given frequent and infrequent shallow culture. What is the significance? Just this: there was no need for the excessive culture. The five cultivations did all that was needed: the mulch was made and maintained and the weeds were destroyed. All that was needed was on hand and the work was done. Hence, a moderate amount of cultivation, if it be lone well, if it keeps weeds out and water $i n$, is to be preferred to very frequent cultivation; not because it is less effective, but because it is a less expensive practise.

When the shallow and deep cultivated plots are compared, a slight difference is noticed-a difference of eight bushels per acre in favor of shallow cultivation. In this case, some of the ronts of the deep-cultivated plot were disturbed and injured-we noticed that-and the yield was cut short. Harl this not heen the case, the yield might have been just as good; it might have been better.

The depth to cultivate growing crops.-This gives rise to the question: How (leep) shall we cultivate? That ques- 
tion has been answered with quite a good deal of certainty. At least a half hundred carefully planned and executed experiments have, by their results, answered in favor of shallow cultiva-

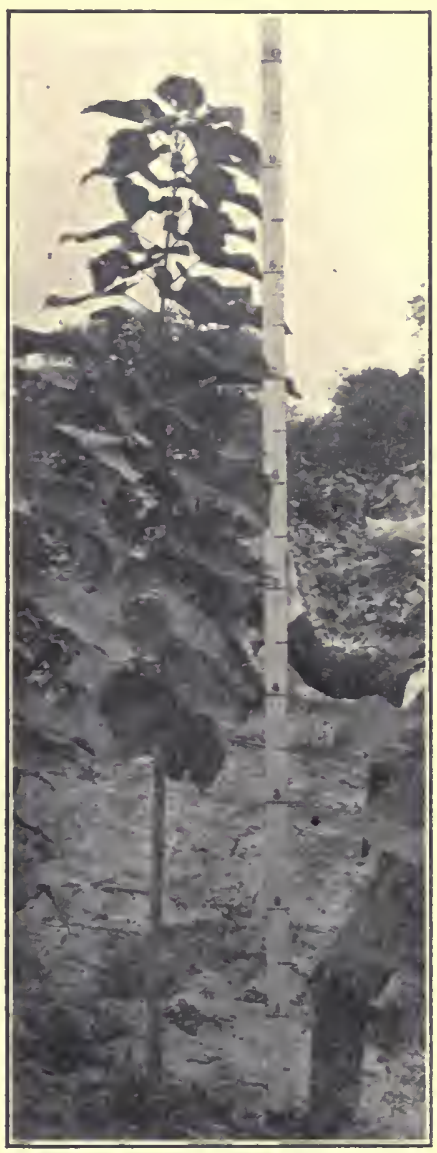

CATALPA TREE WITH ONE SEASON'S GROWTH

But it was cultivated just like corn, and profited by the culture it got tion. Since then we have heard much about this new idea in cultivating the soil. But we are in danger of going to the ot he r extreme. Our fathers "plowed" corn; they cultivated too deep. Some of us, perhaps, cultivate too shallow; we get in trouble with wceds: and because of our thin mulch, let the water get away from the soil.

In sections where there is much rain, the shallow extreme may do: but where moisture is demanded-in the North, where the ground is frozen for so many months: in the semi-arid regions, where the supply is generally limited-a deeper mulch and a more effective mulch is to be preferred. Four inches, perhaps, is too much and one inch is too little. A better depth is from two to 
three inches; better for weed destruction and good enough for mulch making.

A most important point: level culture:-You will find farmers who still ridge their crops: they "hill" the crop that it may not be blown over by winds, nor pulled down by storms and rain. But have you ever noticed that near-by crops, although given level culture, are no more troubled by storms and wind than the hilled and ridged crops? Often not so much, is the true situation.

Hilling and ridging the crop is advisable for just one reason : to drain the land. With proper drainage and seedbed preparation, there is no occasion for either of these expensive practices.

Level culture, since it exposes a smaller area to sun and wind than ridge culture, actually protects, with greater efficiency, the water stores in the soil. Bedding the land is often advisable with some soils (although it increases the cost of planting), for the reason it secures a small amount of drainage and a greater warmth to the soil.

When to cultivate.-You must be in sympathy with the spirit of cultivation if you would get the best results. You must do it at the time when the soil is in the best condition to profit by the work. Just after a rain, the word goes out. But use your judgment here, else you may cultivate too early after the rain and "puldlle" your land. When the next rain comes, the crust caused by the cultivation may be so hard and stiff the rain may slip away before it can secure entrance through the stubborn top.

Here is the better plan: just wait until the soil is slightly dried: enough so that when it is stirred it will not settle and connect with the capillary tubes below-thus defeating the very object you set about to secure. In times when you are depending upon cultivation for water 
preservation it will be worth your while to watch the mulch, to see if it is still an effective blanket or if the connection with the capillary tubes below is beginning to take place. If the latter be so, it is high time that you repeat the cultivating work.

Water-saving means early work.-Water-saving falls into two means-the catching and holding of it. You

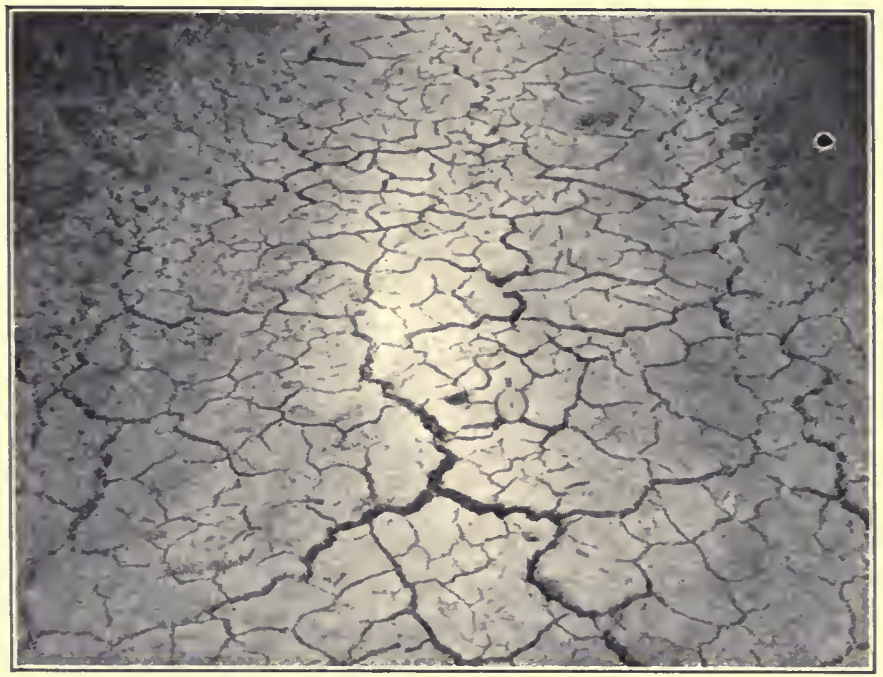

LOSING WATER FROM THE SOIL

The soil is cracked to some depth below. Soil moisture is fast leaving the ground, and the soil is in bad physical condition

first must get water into the soil, and then you can use it; provided, of course, you do not let it escape before it is needed. Too many tillers of the soil fail to understand that the most important principle at stake in water-saving is to till and cultivate in such a manner that there is free access of water into the soil. Then it can be preserved 
by cultivation and mulches throughout the season. But failures in supplying water, although effective culturemulch making-is given luring the growing season, are certain to happen if no water is in the soil to be conserved. If you would have water for plants for the time when they shall need it, if you would have soil water for them for later use, make no mistake about first getting it in the soil, and the rest of the work will be easy.

Just bear in mind these suggestions:

I. Getting ready for crops-opening soils and catching water-is of more importance than after cultivation.

2. Get water deep into the soil and you will have bigger stores of supply.

3. Cultivate after every rain, not when the soil is real wet, but before it becomes very dry.

4. Make your mulch deep enough-three inches is none too deep in dry regions.

5. Open the soil early in the spring with a disk if you have not fall-plowed or winter-tilled.

6. Stir unused summer lands frequently so as to let water in and to keep it in for the next crop.

7. Lands frozen up for long periods-like in the New England territory-are as needful of water-saving as those of the semi-arid or dry farming districts. 


\section{CHAPTER XXII}

\section{STABLE MANURE: ITS COMPOSITION AND ITS PRESERVATION}

The potential plant food contained in a ton of manure is dependent upon five factors: the amount of water in the manure; the sort of feed that has been given the animals; the kind and quantity of bedding that has been used; the care and preservation that has been given; and the class of live stock.

All manure contains water.-Manure contains a great deal of water. If used by weight, it is readily seen how much less valuable a lot of manure containing much water is, when compared with another lot containing a less percentage. Suppose one lot contains eighty per cent. of water and another lot sixty per cent.

In the first instance there is twenty per cent. of dry matter, while in the second instance there is as much as forty per cent. or twice as much dry matter, and, consequently, twice as much plant food. In the first instance, if eighty per cent. is water, you have but four hundred pounds of dry matter in every ton of manure.

In the second instance, sixty per cent. being water, you have eight hundred pounds of manure-just double the quantity. Four tons per acre of the latter kind applied to the soil is as valuable, from the standpoint of potential plant food, as eight tons of that kind containing eighty per cent. of water.

The nature of the feed.-Animals fed on corn stover, timothy hay, cotton-seed hulls, and corn produce manure of inferior quality compared with that pro- 


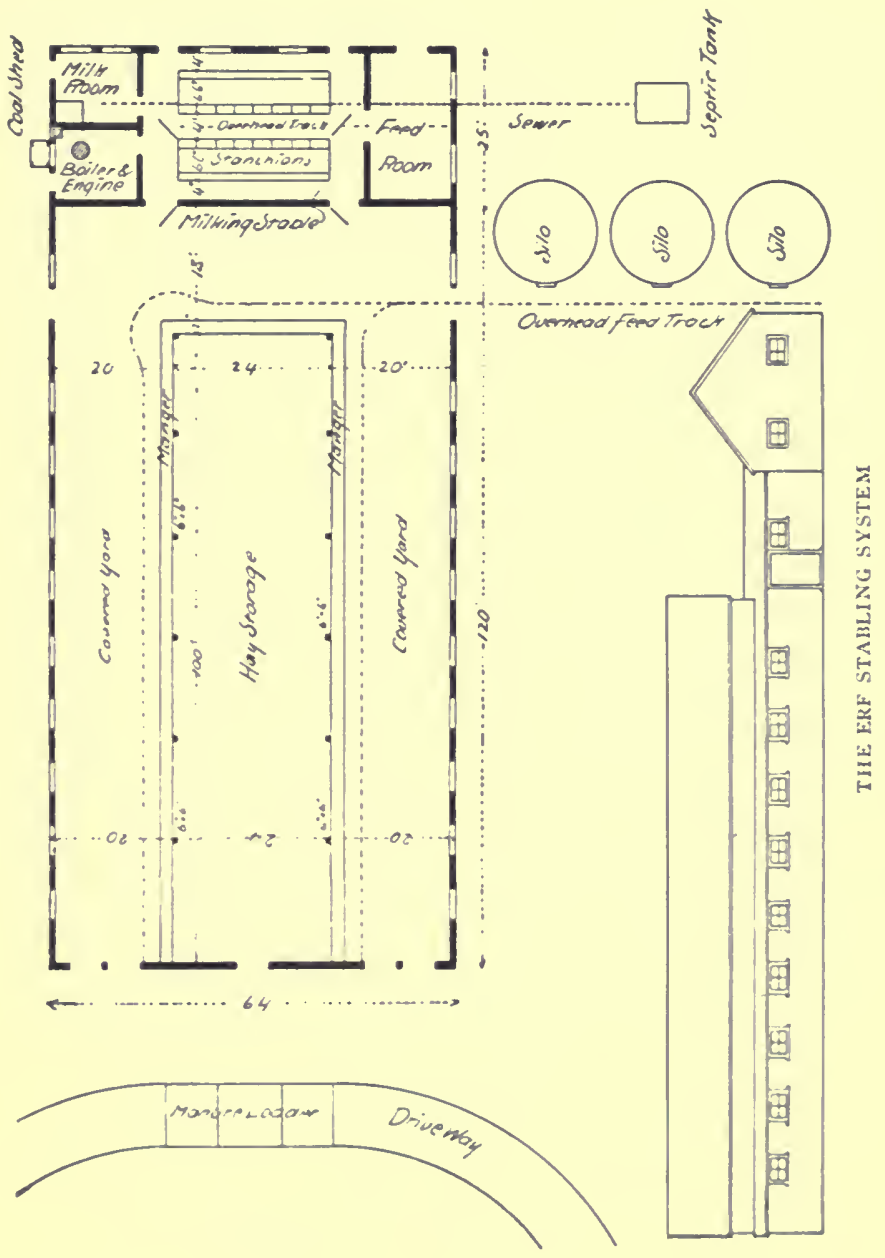


duced by animals when fed on alfalfa, clover, cotton-seed meal, wheat bran, and linseed meal. Manure secured from such feeding is very rich in fertilizing components, and is worth much more to the soil than the manure made when non-nitrogenous feeds are supplied.

How few users of stable manure, even in sections where large quantities are produced, appreciate this point! You ought to be interested just as much in the kinds of feed that have been used as you are in the price you pay for the manure, or in the cost necessary for getting manure onto the land. The table following shows the difference in fertilizing materials in a few common feeding stuffs:

\begin{tabular}{c|c|c|c|c}
\hline \hline \multirow{2}{*}{ Feeding Stuff } & \multicolumn{2}{|c|}{ Fertilizing Elements in One Ton } & $\begin{array}{c}\text { Money Value } \\
\text { of Fertilizing } \\
\text { Elements }\end{array}$ \\
\cline { 2 - 5 } & Nitrogen & Phosphorus & Potassium & \\
\hline Wheat straw........... & 10.0 & 1.8 & 14.4 & $\$ 2.38$ \\
Timothy hay ........... & 18.4 & 6.6 & 28.4 & 4.57 \\
Red clover hay......... & 39.6 & 7.2 & 42.0 & 8.53 \\
Corn ................... & 33.0 & 11.8 & 7.4 & 6.03 \\
Wheat bran............. & 49.2 & 57.8 & 32.2 & 12.58 \\
Cotton-seed meal....... & 135.6 & 562 & 29.2 & 2516 \\
\hline
\end{tabular}

Note.-Values have been recorded as follows: Nitrogen, 15 cents; phosphorus, 6 cents ; potassium, 5 cents.

Bedding has a part.-That bedding has a part in influencing the value is generally recognized. Straw bedding is worth a great deal more to the land than shavings or sawdust. If a great deal of poor bedding is used in proportion to the food consumed, the resultant manure is not so good. If rich grain food is fed the stock and little bedding used, the manure, if properly preserved, will be extremely valuable. Just bear in mind this about bed- 
ding: it is intended to furnish clean quarters for animals, to absorb and retain liquid excrement, to check and control fermentation and nitrogen loss. Hence, it dilutes manure rather than improves its chemical composition.

Care in keeping manure.-The average farmer is quite wasteful with his stable manure: he certainly does not take good care of it. There is not a single section of the country that does not present examples which show manure as being wasted in exposed barnyards, or piled under eaves, or as bcing washed away, and so poorly preserved that the greater part of the nitrogen therein held is released by fermentation and sent out into the air.

The kind of live stock influences value. - Inasmuch as different feeding rations are fed our many classes of animals, it fol-

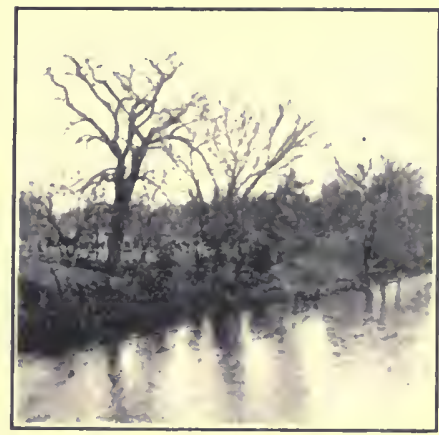

LOSING FERTILITY

Thousands of cattle are ted anmually in vards. where the valuable parts of the manure waste into streams - forever lost to the sril

lows that the value of the manure bears a direct relation to this fact. Hence, growing animals, dairy cows. and other animals receiving fecling stufts relatively high in nitrogenous foods produce fertilizing products of richer fertilizing values than fattening animals or other clasies ferl more carbonacenus feeding materials.

Full-grown animals. neither gaining nor losing weight. excrete practically all of the fertilizing constituents of the forol. while mileh cows excrete on an averace of sevents per cent., and fattening cattle and work horses anumt ninety per cent. 
The table following shows the composition of average farm manures :

\begin{tabular}{|c|c|c|c|}
\hline \multirow{2}{*}{ Fresh Manure Substance } & \multicolumn{3}{|c|}{ Pounds per Ton } \\
\hline & Nitrogen & Phosphorus & Potassium \\
\hline Cow manure $. . . \ldots \ldots \ldots \ldots . .$. & 6.80 & 3.20 & $8 . \infty$ \\
\hline Horse manure ........... & sx.60 & 5.60 & 10.60 \\
\hline Sheep manure ............. & 17.60 & 4.60 & $13 \cdot 40$ \\
\hline Hog manure............ & 9.00 & 3.80 & $12 . \infty$ \\
\hline Hen manure ....... & 32.60 & $3^{1.80}$ & 17.00 \\
\hline Mixed stable manure $. . . \ldots \ldots \ldots . .$. & 10.00 & 5.20 & 12.60 \\
\hline
\end{tabular}

Solid and liquid manure.--In the liquid portions of the manure the digested nitrogen is found, as is also the larger part of the potassium. This explains why the loss is so great, from a money standpoint, when liquid manure is not preserved properly by absorbents, or otherwise held so as to prevent its loss from being washed away. Yet in just this way the greater value of stable manure is never secured to the farm. On the average farm little consideration is given this liquid portion. And then to think: it is the most valuable product made on the farm. And you let it get away!

In the undigested portions of manure some nitrogen is present also. A large part of the phosphorus is contained in the solid parts. Since nitrogen and potassium are contained in liquid manures, and, at the same time, are very soluble in water, the active influence of this sort of manure in forcing vegetation is recognized at once. You can do no wiser thing than to begin at once in the saving of all liquid manures-clearly the most valuable homeproduced manure. 
Preserving stable manures.-If you would protect your farm-made manures, you must abolish that old barnyard built on a hill, the drainage of which finds its way to the creek, where shortly it is picked up by the waters and carried away. Maybe your barnyard is not this sort. but a number of your neighbors have this kind. And here is the point: no one can afford such expensive barnyards; too much valuable capital-real soil fertility-is lost each

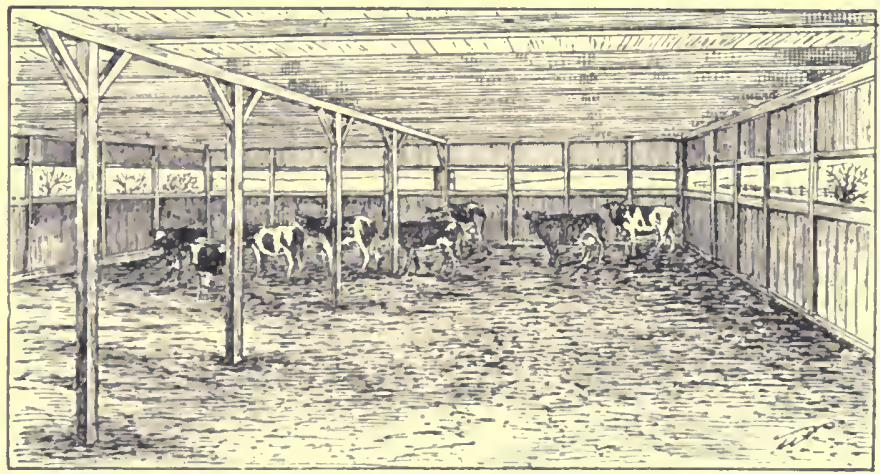

A COVERED B.IRNYARD

Cattle are protected and the manure is preserved

year. You can do one of two things: build a covered barnyard, where manure and stock are covered and protected, or you can remake the old barnyard by banking up the lower side and by scomping a hollow out of the micldle. Now, in neither case can the manure be washed away.

If the bottom of this newly made yard is of clay, there will be little or no leaching. and hence practically no loss. (On the other hand, if the bottom and sieles are of a sand nature, spongy in character rather than impervious, it will be necessary to (ho more work before a good job is 
secured. Some advise cement for the bottom and sides for this purpose-a most satisfactory way out of the difficulty and one that will last.

But the covered barnyard is better. And it is better for the manure and for the stock. The open barnyard, although it may protect against washing and leaching, still may allow fermentation to go on as before, which means organic matter is destroyed and nitrogen is lost. This objection is removed almost entirely when manure is hauled direct to the fields or made and preserved under the covered barnyard.

The most practical scheme for a cheaply constructed building that scrves as storage for hay, shelter for stock, covered barnyard for manures, and at the same time provides stable accommodations, with which I am familiar, is the Erf system.

The Erf sysiem of stabling and preserving manure.The general plan is as follows: In this system location is a very important factor. The building should be built on high ground, but if such is not available, the soil should be tile drained to avoid dampness in the barnyard. In arranging the system, a large area is covered with cheap roofing. in the center of which is a hay shed; on one side of this is a milking stable connected with a feed room for concentrated feeds, and a second room to be used as a milk room. In this plan the cows are kept in the covered barnyard, except during milking time, where they are fed all kinds of roughage feeds. At milking time a portion of the cows are driven into the milking stablewhich is constructed in the most sanitary manner-and fed their concentrated feeds; they are then returned to the covered yard, and the remaining portion admitted to the milking stable. By such a plan a large number of cows can be accommodated with small stable provision. The 
most sanitary arrangements may thus be provided with no great outlay of money, considering the number of cows and the serviceable and sanitary arrangement.

To construct a stable of this kind, proceed as follows: Place twelve-inch cedar poles fourteen feet in length, two feet into the ground. The base of the posts should be set in concrete in order to give greater bearing surface and to preserve the wood. In setting the posts allow twelve feet to project out of the ground. These posts may be placed twelve feet apart, depending a little on the height-the higher the barn, the closer it is necessary to place them. A two-by-six plate is placed on top of these posts, set edgewise to receive the two-by-four rafters placed sixteen inches from the center, upon which the roof boards and roof are placed. The center posts-here is where the haymow comes in-should be at least eighteen feet high, and should be connected and covered in the same manner as described before.

The roof may be made of cheap roofing material corered with tar and then with sand. The slope of the roof need not be more than one inch-a half inch will dofor each running foot. If you wisl a cheaply constructed stable, using this sort of roofing will secure it. If a leak should occur, all you have to do is to remove the excess gravel, add a little more tar, and then place a patch of paper over the part that leaks. This is covered again with tar and gravel, and the leak is stopped. The more of this patching that is done. the more durable the roof becomes. It is simple, and can be acomplished with ease at any season of the year.

For this kind of roofiner. stecp-pitch roofs must be avoided, for the reason that during the summer nonths the tar softens from the heat of the sun and not infrequently rums off the roof. 
The sides may be boarded with up-and-down and batten, or batten-siding may be used. Sufficient bracing is necessary to keep the boards from warping, hence, a proper re-enforcing of the sides is necessary.

It is essential that as many windows be put in the sides of the barn as is practical to use ; in fact, it is a wise plan and the most sanitary form of construction to have a continuous window scheme five feet from the ground to within one foot of the eaves. Besides, with the cheapness of construction in such a system of stabling, the comfortableness for the stock that is provided by such a barn, and the sanitary features it offers for the production of milk, the Erf system will become more and more in use and gradually gain in favor and popularity. It will solve the manure-saving problem and pay its entire cost through this item alone.

It is necessary to have plenty of bedding at all times for this system of stabling. But the yard is cleaned only at such times when soil is dry enough and weather of such a nature as to permit the hauling of manure onto the field. The manure is loaded direct into the spreader and goes to the field in the best condition, and under the most favorable circumstances so far as availability of plant food and original state of the organic matter are concerned.

By allowing manure to accumulate for a foot or more in depth, and by frequent use of such preservatives as kainit, gypsum, or rock phosphate, spread over the manure, a slight fermentation only takes place, and hence, but a slight loss of nitrogen results. Yet decomposition has advanced sufficiently to make the manure readily available for use in the soil.

The air in the stable in this way is kept pure and wholesome.

The advantage of the hay shed in the middle of the 
covered yard and stabling system is that labor is saved during feeding operations. Racks are provided along the hay rick or mow under the covered yard, into which hay or other roughage is thrown from the top of the rick, thus avoiding any hauling, double handling or other minor loss of roughage that is necessary with other stabling systems. 


\section{CHAPTER XXIII}

\section{HANDLING MANURE ON THE FARM}

There are two important uses of stable manure: to furnish plant food and to improve the physical condition of the soil. To get both results you must take proper care of every bit made on the farm.

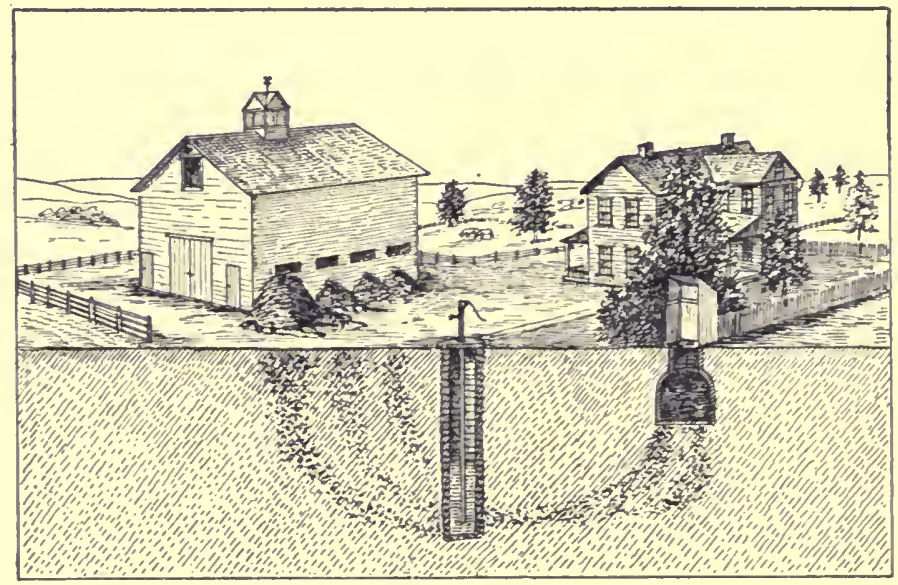

LETTING THE MANURE GET AWAY

At the same time the well water is contaminated from the manure yard and cesspool

A good many years ago Voelcker, in England, showed with proofs beyond doubt that farm manure was used in a very careless and wasteful manner. He showed, for instance, that when manure was thrown into an open barnyard-just as the great majority of our American 
farmers handle it-and there allowed to lie for a few months, it invariably lost from one-half to two-thirds of its total fertilizing value, besides injuring its plysical nature so much that it did little good when applied to the soil. This means that two or three loads of poorly kept stable manure are of no more value when sent to the soil than a single load properly preserved and applied.

Manure properly preserved increases crops.-- In example of poorly preserved and well preserved manure is shown in the field tests of the Ohio Station. which have now been in progress for ten years: two kinds of manure were used, yard manure and fresh manure. In both cases the rate of application was eight tons per acre on clover sod, plowed under for corm, and then followed in a threeyear rotation of wheat and clover without any further manuring or fertilizing. The table following shows the average increase for each crop for both kinds of manure:

\begin{tabular}{|c|c|c|c|}
\hline Kind of Manule & $\begin{array}{l}\text { Bushels of } \\
\text { Corn }\end{array}$ & $\begin{array}{c}\text { Bushels of } \\
\text { Wheat }\end{array}$ & $\begin{array}{l}\text { Pounds of } \\
\text { Hay }\end{array}$ \\
\hline Yard manure........ & 16.03 & 8.21 & 698 \\
\hline Fresh manure.......... & 22.24 & 9.73 & 1280 \\
\hline
\end{tabular}

This is what Director Thorne in discussing these tests says: "Not only has the manure been greatly reduced in (quantity, but the quality likewise has been impaired by exposure-the rain leaching out the most soluble, and, therefore, the most valuable portions. At current prices the average increase from a ton of open-yard manure. including the straw and stover, has heen worth aloout two dollars, while that from the fresh manure has reacherl an average value of nearly three dollars: and this value has been increased to four dollars and fity cents by reinforcing the manure with acid phospluate." 
Methods of applying manure to fields.-Four methods are in use as follows:

I. Piling in small heaps, which are to be spread later in the season.

2. Hauling to fields and piling in large mounds, to be distributed later.

3. Scattering on fields by hand direct from place where made.

4. Distributing by means of manure spreader.

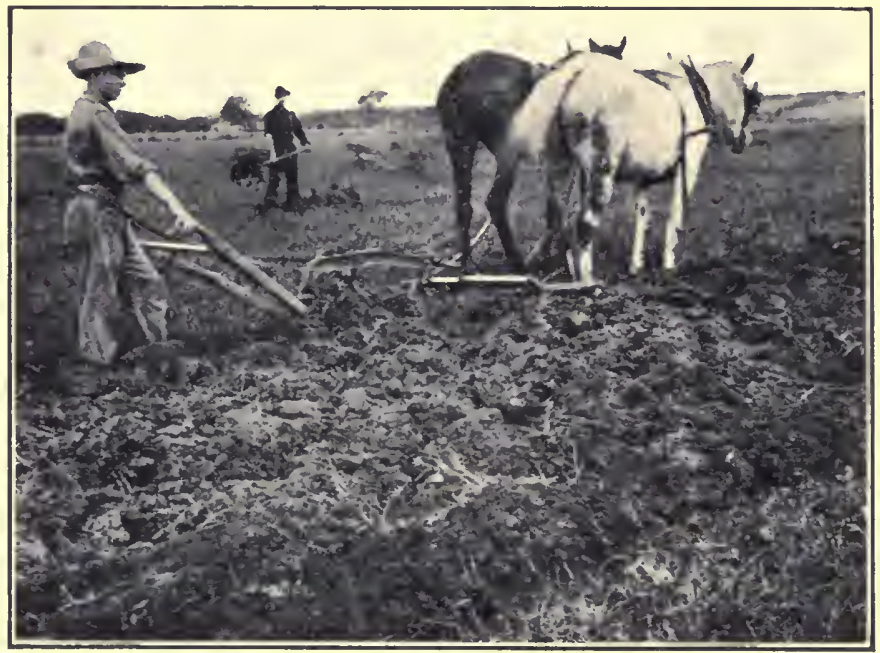

A COMMON WAY BUT POOR PRACTICE

Piling manure in small heaps, while still common, is fast giving way to the manure spreader

Small piles of manure: a bad practice.-For a long time the most common way of applying manure has been this: Wagons are loaded with manure, hauled to the field; here the manure is dumped into small piles, eight, ten or twelve per load. Later in the season, either in the fall, winter 
or early spring, these small piles are scattered and the land plowed. Of all bad methods, this is the most wasteful. It is bad practice: the manure loses its elements, which leach out and sink into the soil; one spot is made rich, the rest of the land receiving an insignificant portion only; on the rich spot the crop-grass, oats or wheat -often lodges and gives no better results than the less favored portions; or the manure heap may heat and ferment, losing a goodly portion of its nitrogen, the element most in demand.

The large mound: now but little practiced.-The piling in large heaps or mounds-thirty to fifty loads to eachis not to be commended unless it can be moistened frecly, that fermentation may be prevented. It doubles the handling and materially increases the cost of application. It should be said that this method is a relic of the old days and now seldom is practiced.

The most common form of application is hand scattering with manure hauled direct from the yard to the field.

Hand scattering is objectionable.-The objection to hand scattering lies in the unevenness of distribution. Even with the best care more or less manure falls in bunches, leaving a great number of vacant spaces to get no manure at all. The result is this: (On some portions of the soil too much manure goes, and on others ton little or none-making a double waste. Here is the opinion of Professor Smith: "Experiments to-clay are wanting to exhibit the losses accruing from throwing the manure at the land in chunks. If manure is hauled out in the clead of winter and scattered from a sleigh box, it is sure to be left in large forkfuls, scattered unevenly. It is impossible to get manure so applied properly worked into the ground to insure the mixing of the decaying organic matter with the soil. Remember that if the decaying manure is not 
mixed with the earth, where its content of plant food will be absorbed, it cannot exert its beneficial effect on the physical character of the soil. A man of experience is tempted to say that one load of manure spread with perfect evenness is about as valuable as two loads on the same area spread in chunks and heaps. This phase of the question cannot be easily exaggerated. Until the manure becomes an unrecognizable constituent of the soil itself, it has not accomplished its mission. It must be digested in the soil, assimilated into the soil system; and this is

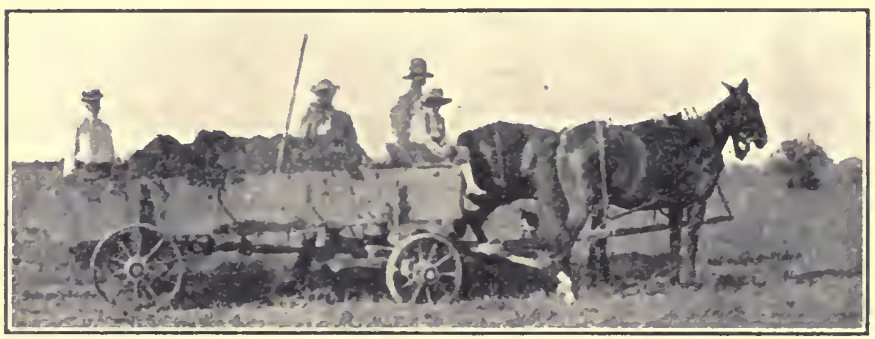

HAULING MANURE TO THE FIELD

To be most effective manure should be drawn direct from the stable to the field

possible alone when it is evenly and uniformly spread."

This waste is avoided when the manure spreader is used.

The manure spreader: it pays good interest.-In the first place, the manure spreader does its work well. It spreads thinly, uniform!y, and evenly-items of much consequence in handling manure. If the growing crop is to receive this farm resource so as to make the best use of it, it should be furnished to the soil in the most wholesome and in the best usable form ; it must be given the soil in a way that allows rapid decomposition and complete, even incorporation into the soil. 
In the second place, the spreader is a labor-saving device. The four-tine fork method of spreading is expensive and out of date. It costs too much to handle manure in this old way; it does the work too unsatisfactorily; it calls for too much labor; it fails in having the manure taken to the field properly, thus securing to the soil the full value of the manure, both chemically and physically. The labor required in spreading a load of

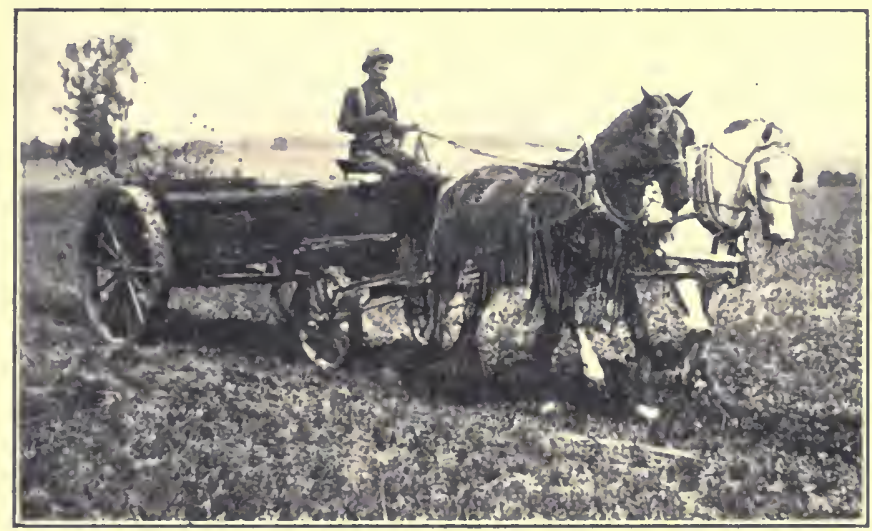

MANURE SPREADER AT WORK

When the spreader is used manure is applied thinlv, evenly and uniformly. Then, too, the cost of application is reduced

manure by the spreader is less than one-half that required by either of the old methods-ly spreading broadcast by hand or by piling in small heaps in the field.

In the third place, the manure spreater pays. I know this suggestion means another costly machine for the farm. The question now arises: ls the manure spreader wortl its cost? It most certainly is. In my judgment there is no machine now used on the farm that pays a better interest on the investment. For simply putting the 
manure on the land in the best form a high rate of interest is paid on the original cost; for decreasing the expense of application a high rate of interest is paid on the investment; for having at hand at all times a vehicle for handling manure as it accumulates a high rate of interest is paid on the investment; for doing all these thingsfor helping the farmer with his work, for removing the drudgery and disagreeableness of handling stable manure - the manure spreader is needed, and its initial expense is met several times each season.

When to apply manure.-Manure shou!d be applied as fast as it is made, unless some good provision can be had for its protection and preservation against loss by fermentation or by leaching. The covered barnyard and the manure pit have come into use and popularity with recent years, doing much in the way of saving manure against loss. These provisions are good only for certain seasons of the year; when it is impracticable to get out on the fields with the spreader so as to make direct application of the manure to the land.

Broadly speaking, the sooner the manure can be got into the soil the better, for these reasons: the organic matter is still intact and the plant food is preserved. The rotting of manure means a waste of organic matter. Such rotting should be allowed to take place within the soil. As the manure rots, so will the soil rot; so will the compounds containing plant food rot and thereby furnish available plant food.

We want a lot of organic matter in the soil, for the reason that organic matter is the basis of humus supply; and hence it regulates the water content of the soil and the activity of bacteria, whose work is so intimately connected with the growth of crops.

That manure materially decreases in bulk and in plant- 
food value is shown in an experiment recorded by Professor Roberts. Starting with 4,000 pounds of manure, the amount decreased to 1,730 pounds; because of poor preservation, sixty per cent. of the nitrogen escaped into the air, seventy-five per cent. of the potassium and forty per cent. of the phosphorus leached away in rain waterin all a loss so great that no farm can stand it even for a short time.

When this pile of manure is considered from the standpoint of its money value, we find that at the beginning it was worth $\$ 5.48$; but after being exposed for five months, the plant-food value was only $\$ 2.03-$ scarcely one-third its original value. Surely no farmer can afford to follow any methorl so wasteful as this. What method lo you follow? Just bear this in mind: If you haul manure to the field and spread thinly over the soil as fast as it is made, say each day or once a week, you will not only save all the plant foor it contains, but you will give the soil all the benefit of the action of fermentation on the soil.

When we consider that at least half of the entire amount of manture made on our farms is as carelessly handled, we can realize in slort order the enormous loss that anmually takes place; a loss in real value as large as the entire crop of American wheat or cotton is wortl. Just take this direction and you will find an explanation for the depletion of so many lands: you will find the real cause of so much poor farming and of lessened yields: you will find, in a large measure, the true meaning of abandoned farms ; you will find the gist of all the troubles that infect the soil, the farm, and the farmer.

These evil results may be eliminated-at least reduced to a minimum-if the manure be applied direct to the ficlels.

Where to apply manure.-You ought not apply manure 
on lands containing a large amount of nitrates. There is too great danger that these will be broken up by the decay of the manure; hence, manure should go to the fields where the supply of nitrates is at their lowest point: during the fall, just after crops have fructified; during winter, when nitrification is slow or inactive; in the spring, when the supply of nitrates is still low. It is unwise, perhaps, in the summer, when the nitrate supply is unused and still large. to apply manure to cultivated

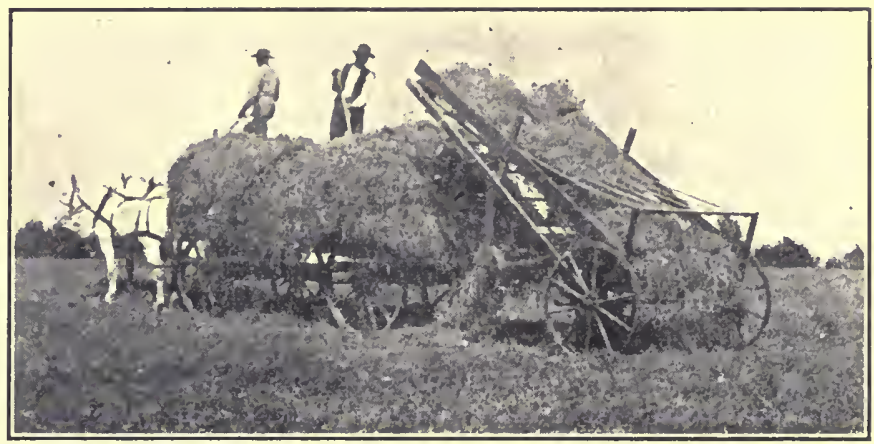

CRIMSON CLOVER IN THE SOUTH

Humus is added to the land and nitrogen is secured for crops. Crimson clover is a splendid crop for the greater part of the South

landis; the risk is too much, for these nitrates are likely to be lost. There is no objection, however, in sending manure at all times, and especially during the winter and spring months, to grass or pasture or mowing fields. A clover sod that is to be planted to corn in the spring is an ideal place for a thin, even, and uniform covering of manure.

How much manure to apply.-As a general rule, it is more scientific to apply small amounts of manure frequently than to supply large amounts at longer intervals. 
This is the best fixed rule that I am able to give. This point has been tested at several stations. In New Hampshire four tons per acre applied each year for three years furnished an increase of thirty-one per cent. more of corn than a single application of nine tons per acre at one time. Commenting on an experiment of a similar nature at the Ohio Station, Director Thorne says: "We have compared the value of manure applied at the rate of four and eight tons per acre. The result has been that the increase per ton of manure has been more than twenty-five per cent. greater when used at the smaller rate, although the increase per acre has been larger when used at the larger rate; hence, when manure is scarce, it is better to apply it in smaller quantities so as to cover all the land in crop, rather than to spread it over part of the land only and leave part unmanured."

The accumulative effect of farm manure.-By the use of barnyard manure a farmer can easily and quickly inprove the soil of his farm and at the same time secure permanent results. Deficiencies are supplied-both plant food and bacterial activity-even with a single application.

The lasting effect of barnyard manure is expressed very clearly by Professor Snyder as follows: "When a dressing of eight tons of manure is applied. which is not a heavy dressing, an increase of twenty busliels of corn is secured the first year. We have secured this much and more in our experiments. It is not difficult to assign a value to the corn. In addition to the increase of twenty lushels of corn, more corn stover is secured, which ean le used for feed and thus turned into manure and mate to add to the fertility of the soil. It is safe to say that the increase in the corn crop alone is $\$$ \%. The value of the manure dres not stop here. If following the corn the second year after the application of manure wheat be sown, 
an increase of at least three bushels of wheat may be secured. This is all due to the residual action of the manure and the better cultivation of the land. The average value of this wheat would be about $\$ 4.50$.

"The additional straw from the larger crop of wheat is converted into manure and returned to the soil. Suppose that clover be sown with the wheat. The manure that the land has received would insure a better stand of clover, and, in fact, it might be the deciding factor as to whether any clover at all would be obtained. It has been shown by experiments that one ton more of clover per acre may be secured on manured land than on that left unmanured. Not only can a ton more of clover be obtained, but there will be more and better pasture. It is hard to assign a value to this crop because of both its feeding and manurial value, but it will be worth at least $\$ 5.25$. After growing clover, the land will increase in crop-producing value. If the clover is followed by wheat, there should be an increase of nine bushels over land receiving no manure, making crop-producing value of the farm manure and clover equal to $\$ 5.25$ for the fourth year. If the wheat is followed by oats, a further increase should be secured. The oats are worth \$3. During the five years the increase in the value of the crops where farm manure was used, clover grown, and better cultivation given to the land should be $\$ 24$. This makes the value of the manure \$3 per ton distributed over a period of five years."

Why should we longer deny our old lands the beneficial influences of stable manure? Why should we longer neglect it and abuse it? Why should we longer offer it the least consideration of all products of the farm? 


\section{CHAPTER XXIV}

\section{BUYING PLANT FOOD FOR THE SOIL}

The three fertilizer constituents are nitrogen, phosphorus, and potassium, for the reason that in lands long cultivated they have been diminished more nearly in the soil. While there is just now a great deal of controversy as to the real office of a fertilizer, still, there is no question

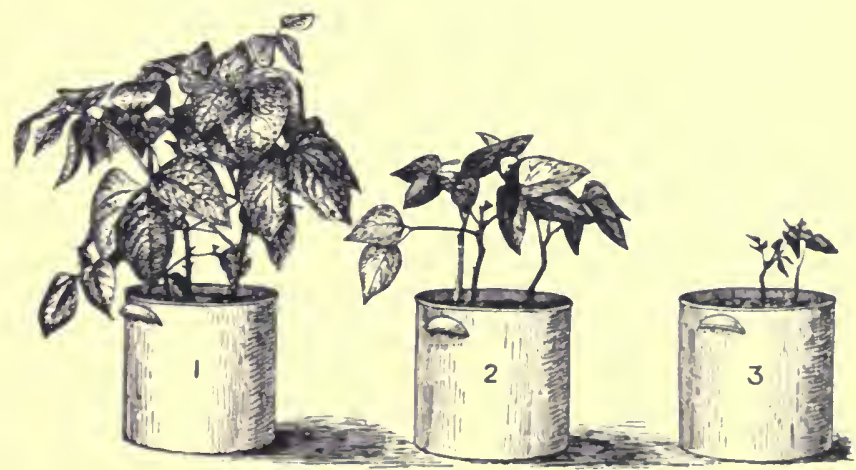

COW PEAS AND FERTILIZERS AND A POOR SOIL

1. Phosphorus and potassium, but no nitrogen

2. Nitrogen. but no phosphorus and potassium

3. No fertilizers of any kind applied

about their value on many lands. It may be that a fertilizer has some other office besicles that of supplying plant food nevertheless, plant food is a factor in soil fertility.

The office of nitrogen.-We have learned that many elements are essential to the perfect development of the plant and that each has a special work to do, which work cannot in any case be done by any other element. Nitro- 
gen, for example, has its most important function in developing stalks and leaves and stems rather than fruit or seed. You observe readily this fact: Where large applications of stable manure have been made, note the heavy, rich growth; and frequently you will find the yield is decreased because of the abnormal growth of stalk and stems due to an abundance of nitrogen in the soil.

You get the same results when you plant a corn or wheat or cotton crop after peas or clover or alfalfa or any other legume that has added nitrogen to the soil. A practical observation is here: when you observe large devel-

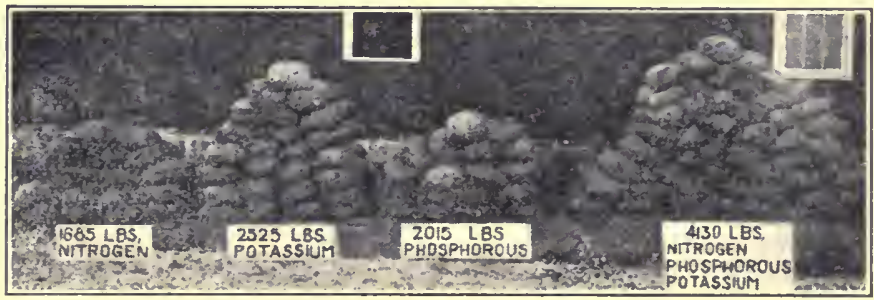

A CASE WHERE ALL THREE ELEMENTS ARE NEEDED

opment of stalk and leaf at the expense of fruit. you may know that nitrogen is not needed in the fertilizer; but phosphorus and potassium, perhaps, ought to be supplied that the plants may produce seed and fruit in proportion to stalk and leaf.

The offices of phosphorus and potassium.-This suggests the main office of phosphorus and of potassium. Both are opposite to that of nitrogen; and both are directed toward increasing the grain or fruit of the plant. When a large amount of some phosphorus-carrying fertilizing material is applied to the soil, the growth of the plants is not more pronounced, but the yield is increased, and, at the same time, the crop matures earlier. On the 
other hand, potassium has a tendency to prolong the growth of crops, but its chief office is increasing the yield or quantity of fruit. Consequently, when the yield is small, you may conclude there is a deficiency of either phosphorus or potassium-or both-in the soil.

And again: if you observe that your plants are of rich. green color and of good size, you may be sure they are not in need of nitrogen. If, however, they are small and pale and sickly in appearance, you may know that nitrogen is sorely in need.

Nitrogen is the most costly element of plant food we buy, and for this reason we should depend upon homemade manures and the various legumes for every bit of nitrogen that is needed on the farm. Of course, we cannot get our phosphorus and potassium in that way. These come from the soil and not from the air; hence, a leficiency in either must come through some artificial means.

Sources of nitrogen.- Thile nitrogen is one of the most abundant of substances, just the same, it is one of the easiest lost and used up in the soil. Jn buying nitrogen as a fertilizer, you must seck a material alrealy having it in combination. In combination with the element hydrogen (which is a constituent of water) ammonia is formed, and a gas it is, also; and it is very soluble in water. The prongent ofor of ammonia water is lue to ammonia gas. Thus we get the same oflor in stables and fresh manure piles: ammonia gas is passing off into the air, later to be brought down by dew or rain. fertilizing. perhaps, snme distant field.

Immonia has a great fombless for sulphuric acirl, and unites with it with vigor, giving rise to a substance white and solid, and known to fertilizer dealers and users as sulpliate of ammonia. 
The commercial sulphate of ammonia contains about twenty per cent. of nitrogen, or four hundred pounds of nitrogen to the ton. In this material the ammonia is held and is prevented from escaping by the sulphuric acid. Sulphate of ammonia is easily soluble in water, and distributes itself through the soil where plant roots can get at it. It adds to the nitrogen stores where come plant roots for the nitrogen necessary to their growth.

On account of the ease with which water dissolves it, sulphate of ammonia is one of our most valuable and

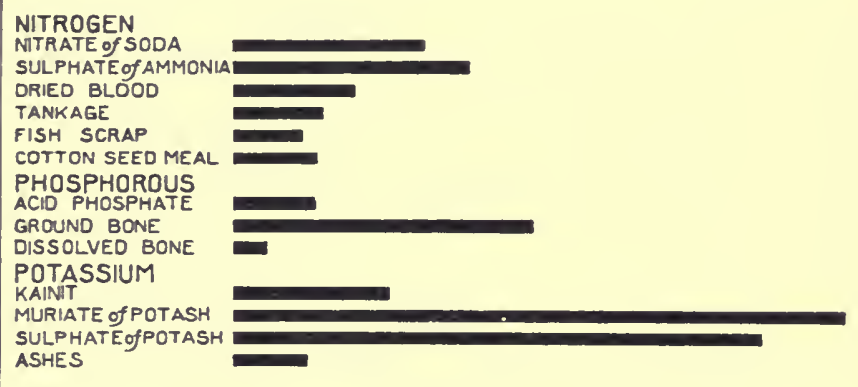

OUR COMMON FERTILIZING MATERIALS

quickly acting sources of nitrogen for plants, but, at the same time, it is one of the most costly sources. It is not as readily washed out of soils as nitrate of soda.

The chief source of supply is at the gas factory, where it becomes a waste product in the manufacture of gas from soft coal, and in the production of coke from coal.

Nitrate of soda or chili saltpeter is a white solid material that is mined in the rainless districts of South America. As found there, it is mixed with other substances, but when purified, it is put on the market as commercial nitrate of soda to be used as a chemical 
manure for lands. When prepared for commercial use, it contains fifteen and one-liali to sixteen per cent. of nitrogen, or 320 pounds to the ton. The remaining 1,680 pounds of the ton are the elements sodium and oxygen, to which the nitrogen is united, and these form the nitrate of soda. In addition to these, forty to sixty pounds of impurities-mostly common salt-are present in each ton of the commercial product.

Nitrate of soda dissolves in water with great ease, and readily distributes itself in the soil. It is in this form that plants like most to use nitrogen, and it is in this form they take it up in greatest abuulance: in no other does nitrogen act more quickly or show its effect more quickly when applied to the soil. So in two or three lays after an application of the fertilizer is made, its effect is seen on growing plants. They show an increase in rigor, a deeper green color is seen, and greater activity in growth is apparent at once.

In this connection it might be worth your while to recall to mind this fact: nitrogen, in nearly every case, enters plants as a nitrate. Sulplate of anmonia. for instance, when used as a fertilizer, sometimes is acted upon by micro-organisms which change the ammonia form to the nitrate form. Of course, there is an oljection when any large quantity of nitrates are present in the soil: it is soluble, and soil water and drainage waters gather it up and carry it away-out of reach of plants. nut into the sea, perhaps. A great quantity of nitrogen is lost in this way each year.

Dried blood contains from eight to twelve per cent. of nitrogen and from seven to fourtern per cent. of pliosphoric aciel, and is the ricliest substance coning from animal products.

When live stock is slaughtered, the blood is collected in 
tanks and boiled that the albuminoids may be coagulated. The water of this material is then removed; the resulting materials are pressed into cake, and later broken, and dried, and ground-all operations essential in making the commercial product.

Tankage.-This is a by-product of the slaughter-house and contains from four to eight per cent. of nitrogen and from seven to fourteen per cent. of phosphoric acid. It slowly decomposes in the soil, and is generally appreciated as a chemical fertilizer. Included in this product are intestines, lungs, tendons, bones, blood, and other refuse. After being cooked in tanks and pressed, it is dried and ground, and then is sent out as a fertilizer or as a feeding stuff for pigs.

Dried and ground fish-or dried fish scrap, as it is often called-is a by-product of the fish-oil and canning factories. Both nitrogen and phosphorus are contained in this product: from six to eight per cent. of the former, and from seven to nine per cent. of the latter. This byproduct is consumed largely by those near the sources of supply.

Cotton-seed meal.-Usually about seven per cent. of nitrogen, or one hundred and forty pounds to the ton, are found in this fertilizing material. It is by far the most important of the vegetable products used as commercial fertilizers. It decays somewhat rapidly, yet lasts long enough so that the growing crop may use it. It is more promptly available than tankage, but much less quickly available than either nitrate of soda or sulphate of ammonia.

Cotton-seed meal is a by-product of the cotton-oil mill. In removing the oil from cotton seed, the seed are cut into bits and cooked and pressed into cakes. These cakes are then ground into fine meal, which may be used either as 
a feeding stuff or as a fertilizer. The amount of cottonseed meal used for fertilizing purposes is very large in the South. It is not economy, however; for a vegetable product so rich in protein as cotton-seed meal to be buried in the ground is poor economy and a waste of wealth. Cotton-seed meal ought first to be fed to live stock and the resulting manure returned to the land. When properly utilized in this way, both humus and available plant food will be secured, or a double profit; a profit from the meal as food, and a profit from it as a fertilizer.

Sources of phosphorus.-Phosphorus cannot be used as a fertilizer in a free state, for the reason it readily

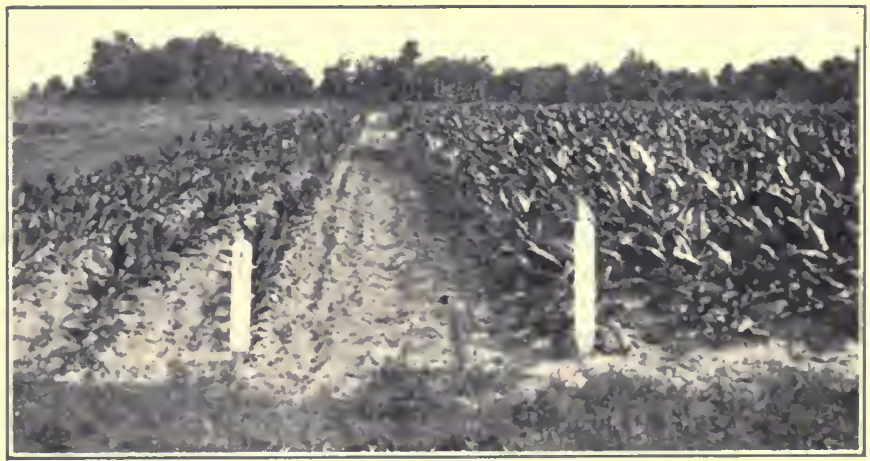

WHERE AC1D PIIOSPIIATE PAYS

Fvery man who uses chemical manures ought to test his land

takes fire. Consequently, when used for commercial purposes it always is found in comlnhation with lime. iron, or some similar substance present in the soil.

A combination of this sort gives rise to what is known as phosphate. Phosphate of lime, for instance, constitutes the main portion of bone and the various phophate rocks mined in North and South Carolina, in Temnessec in 
Georgia, and in Florida. As taken from these mines, this rock contain from twenty-six to thirty-five per cent. of phosphoric acid, the remaining portion of the rock being such impurities as sand, clay, limestone, and water. In its raw or natural state, phosphate has three parts of lime united with the phosphoric acid. The chemists call this tri-calcium phosphate. It is very insoluble in water, and plants cannot use it. To make it soluble in water and fit it for plant food, the rock is finely ground and treated with sulphuric acid, which acts upon it in such a way as to take from the three-lime phosphate two parts of its lime, thus leaving only one part of lime united to the phosphoric acid. This one-lime phosphate is what is known as watersoluble phosphoric acid.

On long standing, this water-soluble phosphoric acid has a tendency to take lime from every substance in contact with it, and in so doing becomes less soluble. This gives rise to the term "reverted" or "gone-back" phosphoric acid.

In this product there is supposed to be two parts of lime in combination with the phosphoric acid and is thus an intermediate product between soluble and the original rock. Of course, in treating with sulphuric acid, some of the ground rock is not acted on by sulphuric acid, and, hence, is left in its original insoluble condition. In this we get insoluble phosphoric acid, as our fertilizer bags often indicate. Available phosphoric acid is made of the water-soluble and reverted; it is the sum of these two; and the available and insoluble make the total phosphoric acid-it includes all the phosphoric acid present.

When you buy fertilizers again; just bear these facts in mind.

I believe you will be more interested hereafter in getting available phosphoric acid than total phosphoric acid, 
if immediate results are desired. If a soil contains plenty of humus, however, it often may be more economical to apply the cheaper, untreated rock. This is especially true if it be applied with decaying organic matter as manure or sod. High-grade acid phosphate is preferable to the low-grade since there is more soluble phosphoric acid in the former and less in the latter.

In making acid phosphate, ground rock and sulphuric acid are mixed in about equal weights, and as a result the acid phosphate produced has only about one-half as much phosphoric acid per ton as the rock from which it was made. Consequently, we find that acid phosphate contains irom ten to nineteen per cent. of phosphoric acid.

Bone fertilizers.-Bone was early used as a fertilizer, and is still popular to-day. The many names for boneraw bone, ground bone, fine ground bone, bone dust, bone meal, and dissolved bone-indicate the mechanical treatment and physical condition of the fertilizer.

Ground bone contains from two to four per cent. of nitrogen and twenty to thirty per cent. of phosphoric acid; steamed bone from one to two per cent. of nitrogen and from twenty-five to thirty per cent. of phosphoric acid; and dissolved bone from two to three per cent. of nitrogen and from twelve to fourteen per cent. of available phosphoric acid. Bone meal is not a quick-acting fertilizer, hence, this material is not desirable when a quickly acting material is wanted: but for lawns. permanent grass lands, and long-growing crops, bone meal is very desirable for both nitrogen and phosploric acicl.

Treated rock and treated bone are the chief sources of phosphorus for plant fond. There are large quantities of each of these materials. and so the cost of phosphorus is moderate in price, and it ought to be used whenever the demands of the soil require it. 
Sources of potassium.-In the olden days our fathers depencled upon wood ashes for soap-making purposes, and learned early of their value as a help for old and worn-out lands. Their value may have been due to the

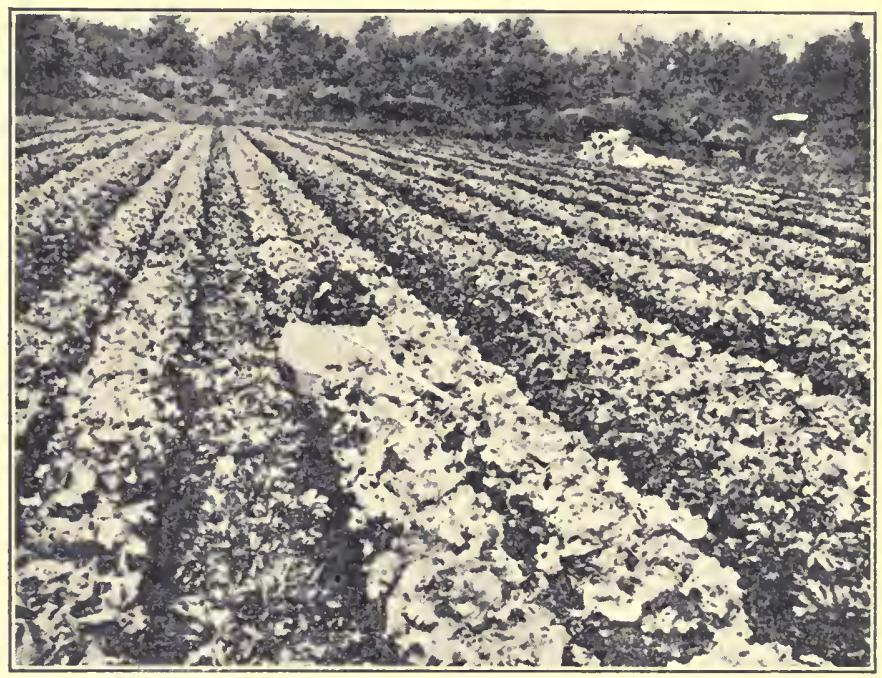

A MUCK SOIL THAT PROFITABLY USES POTASSIUM

A celery and lettuce crop when 500 pounds of sulphate of potash are used per acre

lime present in the ashes (lime, you know, corrects acidity and improves physical condition), or it may have been due to the potassium contained in the ashes, and which served as a plant food.

Wood ashes are valuable, therefore, both for the potash and lime they contain. In unleached ashes, potassium runs from two to eight per cent.-the hard wood supplying the greatest quantity and the soft wood the least. Potassium in ashes is readily soluble in water, hence, ex- 
posure to rain results in the removal of the potassium, so that when ashes are subject to this sort of treatment they lose their fertilizing value.

The chief source of potash materials, however, is the Strassfurt mines in Germany, where they occur in great abundance and variety.

Kainit.-This substance is largely used in the South as a potassium carrier for cotton. It contains twelve and one-half per cent. of potassium, or two hundred and fifty pounds to the ton. It is a crude product of the Strassfurt mines, the impurities present being common salt and magnesium chlorid.

Muriate of potash.-It is a purified product of the potash mines, and is one of the richest materials supplying potassium. It contains about fifty per cent. of potassium, or one thousand pounds to the ton.

Sulphate of potash.-This material contains from forty-eight to fifty per cent. of potassium, an average of one thousand pounds to the ton, which is in the form of sulphate, and it possesses several alvantages for such crops as tobacco and Irish potatoes.

The sulphate of potash is more expensive than is either muriate of potash or kainit, but is less extensively used. although its use is on the increase. 


\section{CHAPTER XXV}

\section{USING CHEMICAL MANURES INTELLIGENTLY}

The use of chemical manures has greatly increased within the last twenty-five years. This has been due to the fact that large areas of land have become exhausted in productive power, and, without the intelligent aid they ought to receive, they are unable to gather strength enough to produce crops with profit unless they are supplied with artificial fertilizers.

Here are reasons that this is so: little thought in maintaining fertility has been given; small quantities of homemade manures have been made and preserved; raw ma

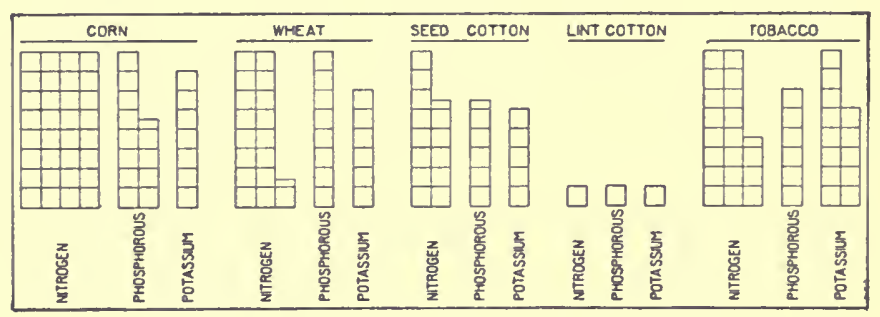

DEMANDS ON THE SOIL BY FOUR LEADING FIELD CROPS (average yields)

terials, like corn and cotton seed, have been sold from the farm, instead of being fed there; poor tillage has been rendered; leguminous crops have been grown in a limited way only; systems of farming have been ill planned; and crop rotation has been ignored and neglected. Just at these points you will find the reasons why the business of making and selling and buying chemical 
fertilizers has reached the enormous proportions it now possesses.

The cost of chemical manures represents a tremendous draft on the profits of the farm; a draft that is paid often with difficulty. With the coming of each seed time, there comes also the ever-recurring fertilizer problem. And it is not solved, and so long as we continue as we are, it never will be solved. What once was a choice is now a necessity; because of the constant dosings, humus has been used up in a soil and many crops in many parts of the country are grown with profit only when the fertilizer drill injects concentrated plant foods into the soil, and in constantly increasing doses.

With good tillage, a wise, well-planned change, a lavish use of legumes, humus and stable manure, the situation will be relieved and chemical manures will be largely unnecessary. If we would remember that fertilizers pay him best who best prepares his land, we would at once make a long step in the correct use of fertilizers, for chemical manures, used most wisely and most economically, go always with high culture and improve soils.

But we ought not blame fertilizers: only our lack of knowledge in using them. We ought not use them as first necessities but rather as supplementary amendments-and they are these-to help in the work of crop production.

Factory-mixed fertilizers: most in use.-The mixed fertilizers constitute the great bulk of trate in commercial fertilizers. As a rule, these are complete fertilizers: they contain nitrogen, phosphorus and potassium-the three elements most likely to be deficient in soils. Of course, the soil may require but one of these elements: but what cares the fertilizer dealer if he can sell you the other two also? That is his business, And it is your 
business to buy only such an element or elements as you need. The real fault is yours: you are slow in ascertaining just what you need.

The elements are now sold in nearly every sort of proportion, and they are supplied in materials of many kinds and names. And it is with regret that one is forced to say that fertilizers are not compounded in accordance with any principle of scientific importance. There scems to be no rational explanation, either, of the proportions as now used in the preparation of goods by the average manufacturing concern. I doubt if there has been any phase of American agriculture that has come into practice more irrationally than that dealing with the compounding and use of chemical manures.

When a farmer wishes to fertilize his land, he usually buys some fertilizer without any knowledge of its effect, without any knowledge that his soil will profit by it, without any knowledge as to whether the yield will be increased. He uses fertilizers solely on the theory that they may pay. He guesses about the matter and then hopes it will be all right. But this is not good business; and it is not good farming. Any other kind of business would be wrecked in a very short time by such methods.

We must get out of the way of adopting fertilizers simply because they have high-sounding names. Just remember that a fertilizer is valuable only in proportion to the amount of plant food it contains. You should be guided in buying factory-mixed goods by the guaranteed analysis, and not by any particular name or brand. Nor is the special brand any better. There is no merit in a special crop fertilizer for any and every kind of soil. It is absurd to believe it to be so. The name is worth nothing. 
Computing the value.-In a commercial way, nitrogen is about three times as costly as phosphorus or potassium. The cost of the fertilizing element varies from year to
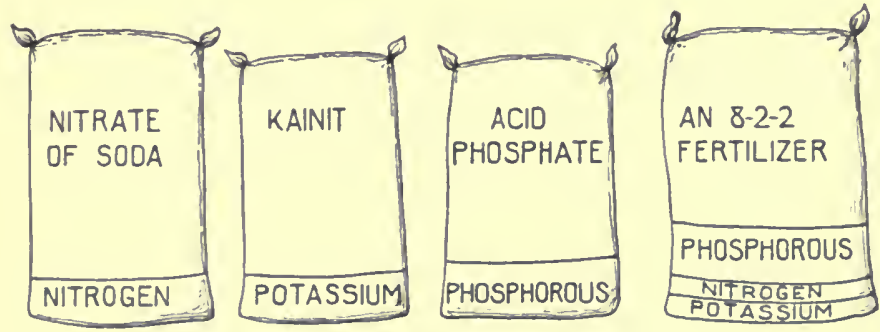

P'LANT FOUD IN A BAG OF FERTILIZER

When buying fertilizers do not make the mistake of supposing all of it is plant food. As indicated above, just a small part is of any value to plants. The greater part is dirt or material of no use to plants

year, but, as a rule, nitrogen is worth fifteen cents per pound and plosphorus and potassium each five cents per pound. In computing relative values, bear in mind that one per cent. means onc pound in a hundred or twenty pounds in a ton.

It is also a grood plan in computing the value of a fertilizer to use the lowest figure representing the percentage, since that more nearly represents the true value. Sliding figures are used more to deceive the purcliaser than to help him or to give him a larerer quantity at the cost of a smaller amoumt.

In oriler to slow the process of eomputing the valuc of a fertilizer. let us take a problem for the purpose of finting the plant-food value of a tom of fertilizer. Ilere is the problem :

What is the money value of the plant fool in a fertilizer containing 1.95 per cent. of ammonia, 7 to 8 per cent. of 
phosphoric acid, and from 2 to 2.75 per cent. of potashthe commercial value being \$30 per ton?

Process: First, reduce the ammonia to nitrogen, since it is the real element of plant food. Ammonia sounds larger and hence is used in the fertilizer formulæ. Remember that ammonia is not nitrogen. It is only fourteen-seventeenths nitrogen, the other three-seventeenths being hydrogen, which has no value whatever as a fertilizer.

So, to get the real amount of nitrogen in the ammonia we shall have to divide the ammonia percentage by I.2I4, so as to get the percentage of nitrogen.

Just do it this way: $1.95 \div 1.214=1.60$ : the nitrogen percentage. We will then multiply each of the several percentages (use only the smallest figures) by 20 , so as to obtain the number of pounds in a ton, and then multiply this product by the value per pound, and we have the value on the basis of a ton.

The following shows the process:

Nitrogen $1.60 \times 20=32$ lbs. at 15 cents $=\$ 4.80$

Phosphorus $7 \times 20=140$ lbs. at 5 cents $=7.00$

Potassium $2 \times 20=40 \mathrm{lbs}$. at 5.4 cents $=2.16$

Value of plant food in a ton

$\$ 13.96$

So here is all there is to this estimate. When several fertilizers are available, just make the calculation in this way and you can then determine in which fertilizer you get the largest quantity of plant food for the least money. For the purpose of comparison, we will take another fertilizer that sells for $\$ 29$ per ton, just one dollar less: its analysis is: nitrogen, 2 per cent., phosphoric acid, 9 per cent., potash, 2 per cent.

With a first glance the average farmer might think the first fertilizer, since it sells for a dollar a ton more, is 
therefore a better fertilizer, but let us see, calculating as we did before:

Nitrogen $2 \times 20=40$ lbs. at 15 cents $=\$ 6.00$ Phosphorus $9 \times 20=180$ lbs. at 5 cents $=9.00$

Potassium $2 \times 20=40$ lbs. at 5.4 cents $=2.16$

$$
\text { Value of plant food in a ton } \$ 17.16
$$

Now you have your comparison: If you take the first fertilizer, you get in each ton $\$ 13.96$ worth of plant food, which costs you $\$ 30$; if, on the other hand, you purchase the second, you get \$I7.I6 worth of plant food for \$29. The difference between the value of the plant food and the selling price is due to the cost of manufacture, profits, agents' commission, etc. In the case of the first this difference is $\$ 16.04$, while in the second it is but SI I.84; a clear saving of $\$ 4.20$ on each ton, and the latter is equal to the former in every sense of the word.

Analysis on bags and

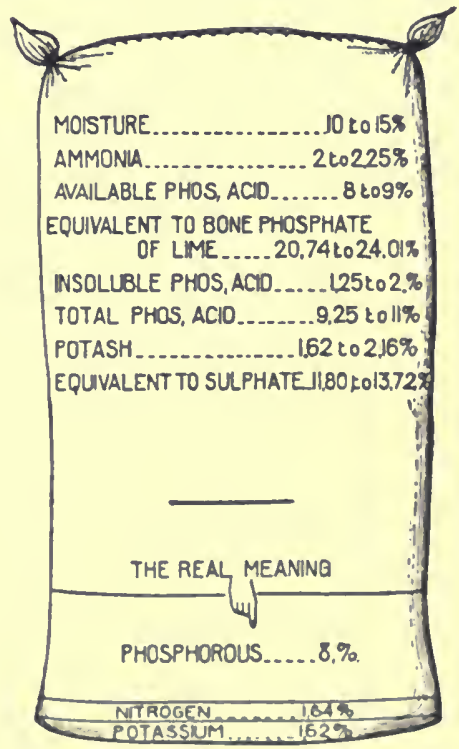
sacks. - In purchasing a THE BA(; ANI) THE PI.ANT FOOD IN IT fertilizer make it a point to interpret as correctly as you can the statements and figures that go with the fertilizer. for unless you do this you may be deceived. Just bear in mind all the time that 
it is available nitrogen, phosphorus, and potassium that you are after, and not high-sounding names or spread-on analyses.

The following is an example of such:

Moisture IO to 15.00

Ammonia

2 to 2.25

Available phosphoric acid.

8 to 9.00

Equivalent to bone phosphate of lime......... 20.74 to 24.01

Insoluble phosphoric acid... I. 25 to 2.00

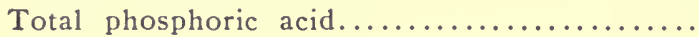
9.25 to II 00 Potash Equivalent to sulphate. II 80 to 13.72

When this statement is reduced to its true meaning, it reads as follows:

Nitrogen

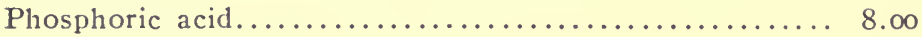

Potash .................................. 1.62

And now another important truth in the purchase of fertilizers: Pay no attention to anything printed on the bag or tag, except to the nitrogen, to the available or soluble phosphoric acid, and to the potash, and then use only the lowest percentage as given for each element. Do this and you will have a clear and correct statement of the real value.

Now, if you use fertilizers, just bear this in mind: chemical fertilizers will not take the place of humus, stable manure, and the legumes. You will use them properly only when you consider them as supplementary helps in the fertilization of your lands. The quicker you realize that prescribed formulæ are only general and that you must use such as guides rather than as specifics, you will the quicker profit in using chemical manures. If you 
think your soil is deficient in some element of plant food, make a test on your own farm in your own field. Ask the plant. Just as you must feed and test your own feeding stuffs, using real, live animals for the purpose, so you must test your own soil and consult with the plants in your own field. 


\section{CHAPTER XXVI}

\section{MIXING FERTILIZERS AT HOME}

Home-mixing of fertilizers now is a much discussed question. So much good sense is in the proposition, so closely is it allied with savings and profits, so reasonable, too, is the preliminary cost-no farmer can afford to ignore a careful study of the simple principles upon which it is based.

A few farmers have adopted the plan of purchasing unmixed ingredients and of mixing them at home. They have been doing this a long time. They like the plan. They find it pays. But you need to give some study, some care, and some knowledge to the work of homemixing, if you would get the best results.

The fact that all standard fertilizing materials may be purchased readily, and mixed together, producing a fertilizer equal in worth to a similar factory-mixed brand that sells for from $\$ 5$ to $\$$ I 5 a ton more than the homemixed fertilizer, suggests the wisdom of this home-mixing plan.

Poor mixing: the chief disadvantage.-The chief objection to home-mixing of fertilizers is poor mixing. Knowledge of this fact has led the agent of factory-mixed goods to advance strong arguments in favor of his product, as against the farmer doing the work himself.

I admit that the factory is peculiarly prepared to mix fertilizing materials in the best way, but there is no reason why the farmer should not do the work equally as well. I will admit that many farmers do mix their materials poorly, but that is not a sound objection to the 


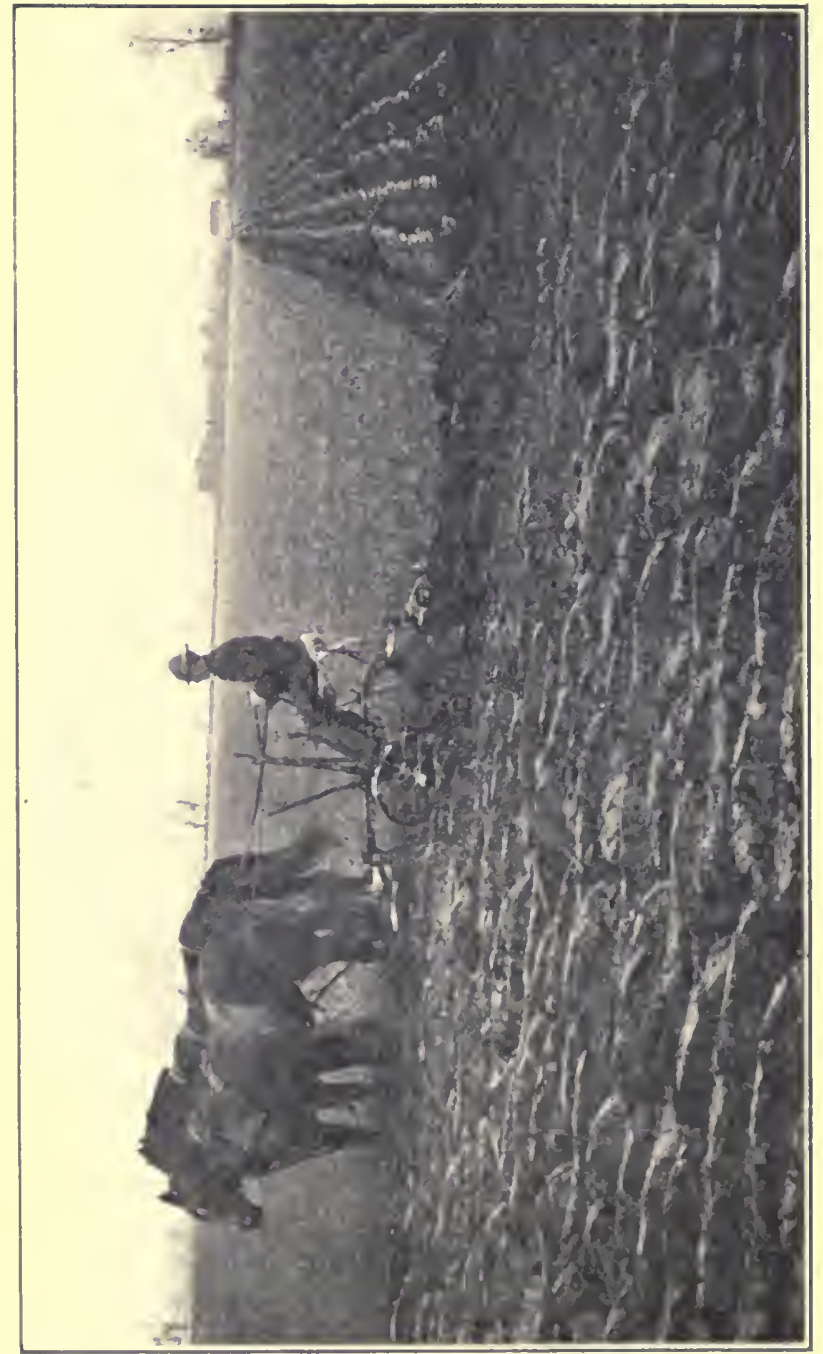

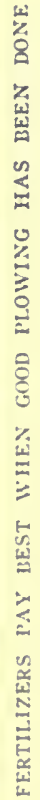


principle. Maybe the same farmers prepare their soils with little care; they may plow poorly. But shall you condemn the plowing idea because it is not done in all cases, in the best manner, and according to the best information and knowledge?

The objection, then, is only apparent: it is not real. The business-like farmer will employ home-mixing because it is a saving to him; because he can make ten to twenty-five dollars for each day he gives to this work; and because he can get a better fertilizer.

Home-mixing means definite knowledge.-When the different materials are purchased and mixed at home the farmer can know, with more certainty, just what he is adding to his soil. When mixed goods are used, it is not easy to detect inferior articles. The chances are the farmer will get better materials in home-mixed goods than in factory-mixed goods.

By careful observation and experiment the farmer can compound his mixture in a way to adapt it more nearly to the needs of his crops and soils. Manufacturers claim to manufacture goods that are of especial value to some special crop, but this is not true, although it ought to be true. This is because the manufacturer is unacquainted with the needs of the soil, and he knows nothing about the system of farming that has been or now is being followed. Consequently, the composition of the crop (and the manufacturer largely takes it into account) is not a dominant factor for consideration in compounding fertilizers.

Here is a case: Two farmers on adjoining farms grow wheat. It is a money crop with both. Their soils may be quite similar in formation; both farms may be drained equally well; both farmers use the same seed, but one feeds many cattle and makes much manure for his land 
and he is a legume farmer also. The other farmer neither feeds stock nor grows any legume. Now, do you think it good sense to use the same wheat fertilizer for both farms? On one farm there is nitrogen enough, but on the other it may be lacking and greatly in demand by every crop seeded there. For let us remember that where stable manure is made and preserved in a proper way, and where legumes are grown as they ought to be, then there is no need of nitrogen being applied to the soil, although the crop may be exhaustive in character and may come frequently in rotation.

On the other hand. phosphorus and potassium may be lacking in the soil. Grain crops may have lepleted your lands of one or both of these elements. The supply may never have been large. We have soil types on record that show a lack of phosphorus, and we have others that show a lack of potassium. A crop of legumes seemingly may increase the quantity of either in the top soil, but these elements both have been got from the subsoil ; and later, when plowed under, the phosphorus and potassium stores may be larger, but the increase has come from the subsoil.

In these cases, there has simply been a transfer from the farm bencath to the farm abowe: there has been no real addition of plant food to the soil. Conseguently. if lands are deficient in either phosphorus or potassium, the deficiency must be made good in some ontside way: by manures or commercial fertilizer, or hy using such material or materials that is needer as a reönforeenent of the present stores.

Test your lands.-Your first gutestion naturally is: What element, or clements, is lacking in my solil? "The only way by which a real scientific answer can come is hy means of an experiment made hy you on your wwn farm, 
and in every field for your leading money-crop or crops. It is necessary, then, for you to make a test that you may know what is demanded in way of an artificial manure for your soil.

Suppose you try this plan: Lay off six plots-each plot to be one rod wide and eight rods long-one-twentieth of an acre in area. In the field your experiment would show a scheme like this:

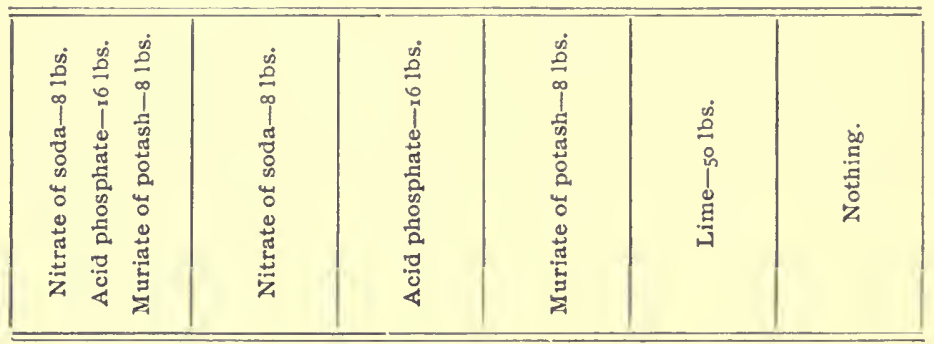

Apply the fertilizers broadcast and harrow in lengthwise that no part of them may be dragged over onto another plot. I find it advisable to mix fertilizers with dry dirt when small quantities are used that a more even distribution may be secured.

If such a test is made with corn, be careful to treat all plots alike in cultivation, and this cultivation should be similar in nature to that given the remainder of the field. A careful observation of plots during the growing season, coupled with an estimate at harvest, should enable you to use fertilizers with some knowledge of their value, if such is shown by the test. The results cannot fail to be helpful in deciding what kinds of plant food your land needs, and in what quantity each element is needed.

The quantity you shall use.-No hard and fixed rule can be given as to the quantity of the fertilizer you shall 
use. That depends upon several things, sucl as: inherent richness of the land; thoroughness of tillage and preparation; nature of the crop) (is it a legune or not) : richness of the fertilizer; and nature of climate and season. If you are a careful observer, your juclgment will help you very much in settling this difficulty.

Just remember that the only way to know the soil well is to study it well: you must watch it and experiment with it. And so, in feeding it with artificial manures, you must consider all these points if you would know just how

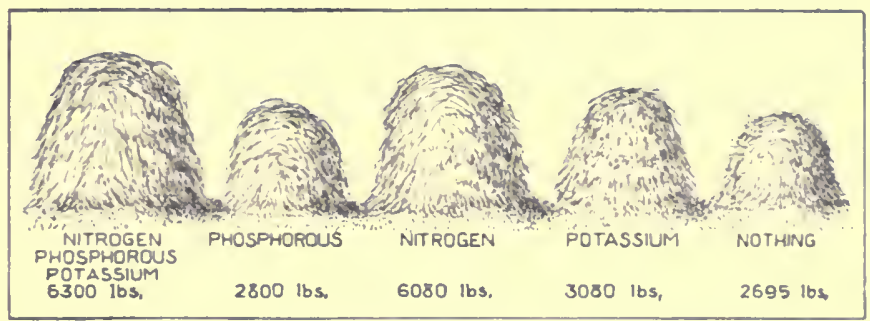

THE SO1L TELLS 1TS OWN STORY

much of fertilizers per acre you sliall apply. Put you hat better do some testing work. II ith corn, for instance. yuu can apply, on two rows, two lundred pounds of the fertilizer per acre; on the next two rows, four liumlred: on the next two rows. six lundred; on the next two rows. eight hundred; and on the next two ruws, one thomsand pounds per acre. Fvery sort of cultivated crop). inclueling corn, entton, potatoes, and tobacco. may he subjected to such treatment, and the soil will reveal the secret it holds-if one is there.

When and how to mix.-I like the winter season best for mixing fertilizers: it gives one plenty of time to get his materials together; labor is avalable, and you can 
do the work well before the rush and hurry of plowing and planting. When you consider the fact that you are receiving extremely good wages for mixing fertilizers, you ought to give good service to this important piece of farm work. You will find a tight-barn floor an excellent place for the mixing, and the work will interfere in no way with feeding and other barn work.

Some people prefer a wagon box for this purpose, and it is just as good: you have only to take your choice.

In mixing the different materials, spread them over the floor to a depth of five to ten inches, putting the bulkiest fertilizer first. On top of this spread layers of the remaining materials; then mix thoroughly, shoveling the entire pile over several times. When a great many tons are to be mixed, this operation will need to be repeated often, and the materials bagged as mixed. You may find some of the unmixed materials hard and lumpy in the sacks; if so, just put them in a separate pile and break up finely with maul or shovel. You will then have no trouble in handling in the way indicated above.

Some fertilizer problems. - Fertilizing materials may be used singly or in combination with others. A great number of combinations can be made to suit all sorts of soils and every kind of crop, by using a few or many of the fertilizing materials. To clearly understand these fertilizing problems, let us take them up one after another.

Here is the first problem: Suppose a ton of homemixed fertilizer is made of $\mathrm{I}, 200$ pounds of acid phosphate, 400 pounds of cotton-seed meal, and 400 pounds of kainit. What will be the quantity of nitrogen, phosphorus, and potassium in a ton?

Process: First, we must know the composition. In nearly every State the law requires the correct analysis to be printed or stamped on the bag in which the material is 
shipped. Consequently, if you know how to interpret these figures, you will have no difficulty in making your calculations. Now we find (you can consult any book of reference for the composition if not given on the bagr) acid phosphate contains fourteen per cent. phosphoric acid, cotton-seed meal seven per cent. nitrogen, two and one-half per cent. phosphoric acid and one and five-tenths per cent. potash, and kainit twelve and one-half per cent. potash: hence we get-

Acid Phosphate-

$1200 \times 0.14=168$ pounds of phosphoric acid.

Cotton-Seed Meal-

$400 \times 0.07=28$ pounds nitrogen.

$400 \times 0.025=10$ pounds phosphoric acid.

$400 \times 0.015=6$ pounds potash.

Kainit-

$400 \times 0.125=50$ pounds potash.

IVe get now-

\begin{tabular}{|c|c|c|c|}
\hline \multirow{2}{*}{ Material } & \multicolumn{3}{|c|}{ Fertilıing Flement } \\
\hline & $\begin{array}{c}\text { Phosphoric } \\
\text { Acid }\end{array}$ & Nitrogen & Potash \\
\hline Acid phosphate.................. & 168 . & $\infty$ & o. \\
\hline Cotton seced meal................ & 10. & 28. & 6. \\
\hline Kainit ......... & m. & $\infty$ & 50. \\
\hline$\ldots \ldots \ldots \ldots \ldots$ & 178. & 28. & s6. \\
\hline
\end{tabular}

PRO)BLE.Y 11: In a ton of fertilizer mixed in this way what is the percentage ef each element of plant fond?

Process: To find this pereentage divide cach clement ly the total amomnt of the mixture. The calculation is as follow's :

Phomphoric acid $178 \div 2000=81$ per cont Phomphoric Acid.

Nitrogen $28 \div-2(x)=1.4$ per cent Nitrogent.

Potash $5(1 \div 200 x)=28$ per cent. P(na-h. 
Working from percentages.-Often the per cent. of phosphoric acid, nitrogen and potash suitable to a crop is given. In what quantities shall given fertilizing materials be mixed so as to supply a fertilizer possessing these percentages?

PROBLEM III: How many pounds each of acid phosphate, sulphate of ammonia, and kainit will be needed to make an $8-3-3$ fertilizer?

Process

In roo pounds. In one ton

Phosphoric acid 8 per cent............. $8 \quad$ I60

Nitrogen 3 per cent.................. $3 . \ldots$

Potash 3 per cent.................... $3 \quad 60$

Acid phosphate-I4 per cent. or I4 pounds in roo. To get 160 pounds divide 160 by $. \mathrm{I}_{4}=\mathrm{I}, \mathrm{I} 42+$.

Sulphate of ammonia-20 per cent. or 20 pounds in 100 . To get 60 pounds divide 60 by $.20=300$.

Kainit-12.5 per cent. or 12.5 pounds in Ioo. To get 60 pounds, divide 60 by $.125=480$.

We have now:

Acid phosphate....................... I, I42t pounds

Sulphate of ammonia................. 300 pounds

Kainit ............................. 480 pounds

Total ........................ I,922 pounds

Unfurnished .................. 78 pounds

2,000 pounds

The remaining 78 pounds may be supplied in fine sand, road dust, or in any such material.

If the reader considers his fertilizing problems in a careful way as suggested here, he will have no difficulty in mixing his own materials, and he will be pleased most certainly with the results. 


\section{CHAPTER XXVII}

\section{DAIRYING: AN EXAMPLE IN SOIL BUILDING}

Dairying is one of the most effective practices in agriculture for retaining and restoring the fertility of the soil. A great array of facts are on record that prove that soils, devoted to dairying, may be as fertile after centuries of farming as they were in their original state. In European countries, as well as in all parts of the United States, we find farms that once were abandoned because the soil fertility was exhausted: it did not pay to farm them. As a last resort, dairying was introduced and the fertility was restored completely. Many of these farms are even more fertile to-day than they were in the beginning, and so long as dairying is carried on, they will continue to increase in fertility and productive power.

Grain farming exhausts the soil; dairying does not.In grain farming the fertility is removel from the farm by selling the grain. Accorling to Professor $1 V^{\circ}$ oll of the Wisconsin Experiment Station approximately \$9.35 worth of fertility is removed from the soil with the sale of every ton of wheat. With every ton of corn that is sold approximately $\$ 6.50$ worth of fertility is removed from the sril.

liut in the case of dairying-where buter is makle nu the farm and where all the hy-products are fed to pigs

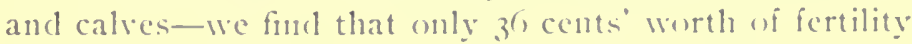
is removed in each ton of butter produced. The commercial value of a ton of wheat at 75 cents per bushel is approximately $\$ 24.75$; but the conmercial value of a ton of butter at 25 cents per pound is \$500. Hence, fint 





each \$IOO worth of wheat that is sold from the soil $\$ 34.50$ worth of fertility is removed from the farm, but for every \$Ioo worth of butter that is sold, seven cents' worth of fertility only is removed.

This vast difference between wheat and dairying is explained in this way: a cow is fed a ration, say, of alfalfa and corn. Both the alfalfa hay and the corn have been raised on the farm. When consumed, the cow has assimilated approximately ten and one-half per cent. of the fertilizing elements. The remaining eighty-nine and onehalf per cent. goes back to the soil in the shape of manure. $O f$ the ten and one-lialf per cent. of fertilizing elements that is retained by the cow, about three-fourths go to make milk, and one-fourth to the maintenance of the body.

In the case of butter marle in the farm. The milk is separated: its analysis shows that ninety per cent. of the fertilizing elements of the whole milk is found in the skim milk; hence, cream and butter remove but ten per cent. of the whole amount. But the skim milk is returned to the farm and is fed to pigs and to calves, which utilize a part of these materials for building up the borly: the unused part passes on to fertilize the land.

Dairying is a fat-making process.- It may be sail that dairying is a sort of fat-concentration process. "That is to say, the resultant probluct. Which is butter fat, is distilled from corn and alfalfa hay (and from all other materials used as fown through the ageney of the latiry cow. the cream separater, and the chmrn-by means of which the distilling prexess is carried oth.

liutler fat, from at elsemical stamlpuint, is a concentrated furm of heat. 'The lecat enmes from the smo, in the first place. It is then taken nj, l, gy growing plants-such as enter into feeding rations-and male into palatable 
products for the cow: made into products that satisfy hunger, and produce heat and fatty tissue in the body of the animal. Speaking strictly, this is one way by which man can sell concentrated heat for butter prices. Now, if the dairyman harvests hay and grain as feed and applies nothing whatever to the land to replace the fertility withdrawn, he will gradually reduce the fertility of the soil, but the process of tearing down will be slow. In twenty years a wheat farm may be worn out by continual cropping, but to wear out a dairy farm to an equal degree, 9,720 years will need to pass. Wheat raising makes swift work in ruining lands, but dairying preserves them.

Dairying remakes the soil.-A great source of profit in dairying lies in the fact that it remakes the soil. When you purchase feed for the cow that more milk may be produced, you add fertility to the land. Such feeds as linseed meal, cotton-seed meal, and bran are exceptionally rich in fertilizing elements. It is not unusual to purchase elements of fertility more cheaply in the form of feeds than in the form of fertilizers. And the feed is paid for by the milk. The milk pays also the labor and allows, in every case, where attention and care are given, a fair margin of profit. In this way the fertility of the soil is restored at practically no cost.

While soil building can be accomplished by using other classes of animals, it is, however, a fact that the dairy cow produces more real fertility than any other farm animal. A cow weighing from twelve to thirteen hundred pounds, if fed to produce milk, during the year produces about twenty-eight hundred pounds of manure. Nearly onehalf of this is liquid and should be saved, for it is exceedingly rich in fertilizing elements. But right here comes a great loss to the average farm. The liquid manure gets away from the land, which would not be the case were it 
guarded as its importance merits. Liquid manure is even more valuable than the solid manure, and if proper arrangements are made, it will take care of itself, and will not only fertilize the soil to which it should be passed, but it may be used for irrigating the land at the same time.

This can be done by means of a septic tank if the gutters in the stables are properly constructed so as to allow it to pass into the septic tank. When there, it fer-

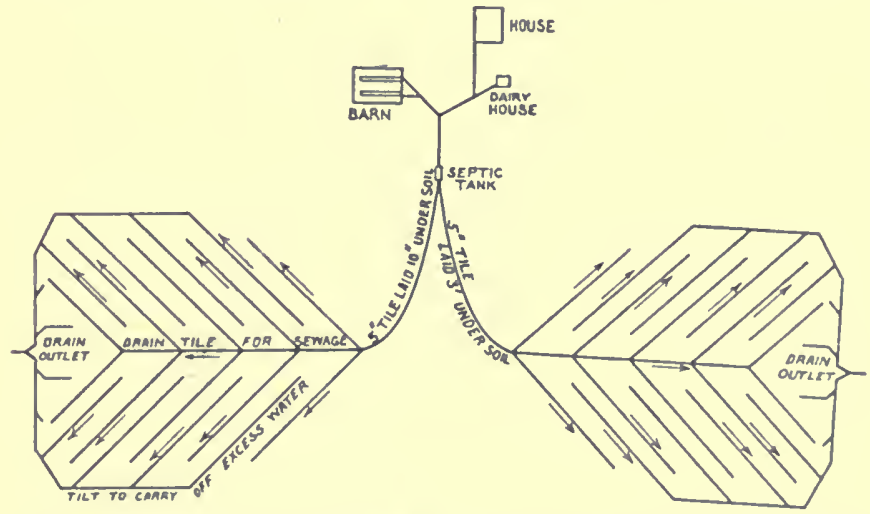

A COMPLETE IRRIGATING SYSTEM WITH DAIRY HOL'SE ANI RESIUENCE ATTACHED WITH THE SAME SYSTEM OF TIE BARN

Designed by Professor Oscar lirf

ments and later is discharged thromgh a system of tile drains, onto the land, where it beconnes distributed into all parts of the soil. The solid manure can now be hatuled onto other fields with half the halder that otherwise would be required, and all the fertilizing constitnents in the manure can be completely recovered and restured to the soil.

The loss of manure ought to be grabeled against with zealous care; certainly with as much as is given th ghatril. 
ing against the loss of any other farm product. For it must be borne in mind that the manurial value of feeds like bran, after it has passed through the cow, is worth $\$ \mathrm{IO} .50$ per ton; of red clover, under the same conditions, approximately $\$ 7.30$ per ton; of linseed meal, $\$ 16.77$ per ton; and of cotton seed meal, \$19.70 per ton. This bears out the statement made elsewhere, that the fertilizing elements in manure are governed by the feeds that are fed

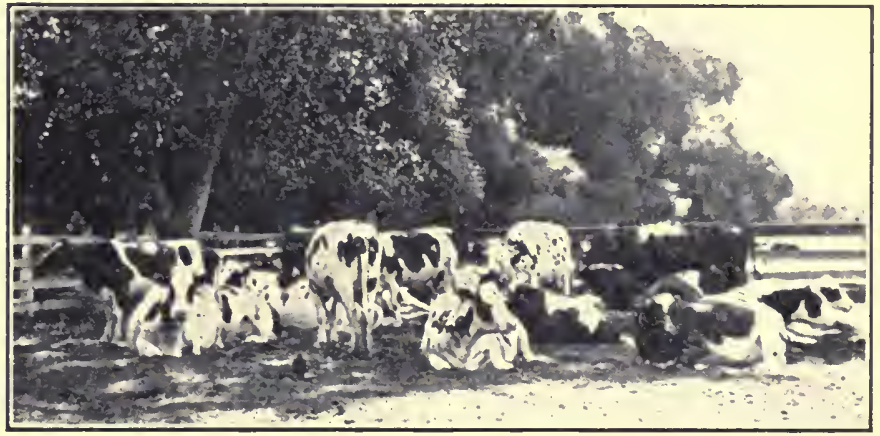

A BALANCE WHEEL IN FARMING

A grain crop makes swift work in ruining lands, but the dairy cow preserves them

to the cow. Hence, rich feeds make rich manure: poor feeds, poor manure and little product.

Dairying is behind rich lands.-Dairying sets in motion the processes that make rich lands: that make plant food available. Your land may contain an abundance of plant food, but it may be unavailable as food. Dairying will set the strings going: it will produce the food for plants in a soluble way and in abundance. Suppose you are served a cup of tea. You taste of it and find it is not sweet; but you are told that sugar has been added and you should stir the tea: it now becomes sweet. The sugar, in this case, remained at the bottom of the cup 
and was not available until thoroughly stirred and dissolved; until then there was little sweetening effect.

So it is with soil fertility. Until it becomes soluble it is not food for plants. Manure has a disintegrating action on fertilizing compounds: it sets free the plant food.

Dairying: a balance in fertility.-An illustration may now be in place to show the important rôle that dairying plays as a soil builder in the realm of agriculture. Let us assume that a man purchases a farm of one hundred acres for which he pays \$roo per acre, the whole amounting to $\$ 10,000$. In this case, he invests his money in soil fertility, from which he desires to draw interest just as he would were he to deposit his money in a hank.

We will now assume that wheat is grown on the farm: on the entire one hundred acres and for twenty years, the rate of production being sixteen bushels per acre, wlich, according to statistics, is a high average for twenty years of continual cropping on good soil without the addition of chemical or stable manures. At eighty cents per bushel, the entire production of wheat, at the end of twenty years, will amount to $\$ 25,000$.

liut there is still another side: with each ton of wheat there groes $\$ 8.35$ worth of furtility: with the entire yield for the twenty years there goes $\$ 8,8,32$ in fertility-leaving $\$ 1,168$ only, ont of the entire origrinal investment. Instearl of simply (lrawing interest on the capital invested. there has heen drawn nearly the entire capital. ()n the face of the purchase eighty-eight per econt. of the origrinal investment has been withdrawn by twenty years of continual eroppling.

Me now will assume, that instead of wheat alone, a dairy leerd of fifteen cows is maintained in comnection with wheat farming: that all the grain fed to the enws is purclatsed: and that the nomure is carefully pre- 
served. It has been determined that a cow produces fourteen tons of manure per year; but since there is always some waste, we will say that ten tons only are recovered, each ton of which is worth $\$ 2.95$ per ton, as actual cropproducing experiments have shown to be the case. On this basis of valuation, the fertility from the fifteen cows will be worth, annually, $\$ 442.50$, or $\$ 8,850$ for a twentyyear period.

Besides the value of the fertility, there is to be added to the gross receipts of the farm $\$ 18,720$, received from

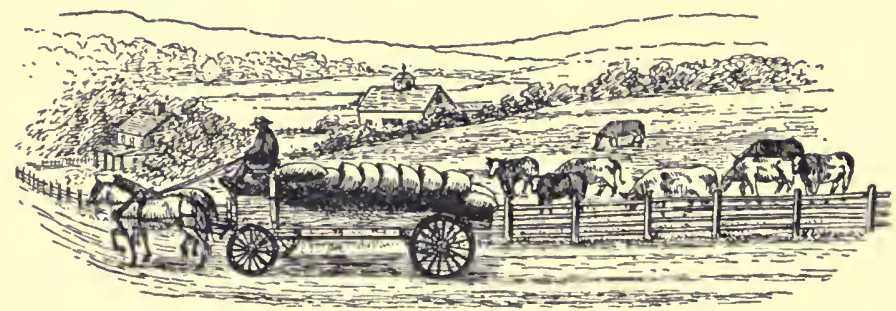

TWO KINDS OF FARMING

Grain farming forces plant food from the soil, but the dairy cow maintains the fertility of the land

the sale of butter fat, and $\$ 3,600$, the value of the skim milk; and these have paid for feed, and labor, and some is left for profit. If the manure has been cared for and distributed properly over the soil, the fifteen cows in twenty years have replaced the $\$ 8,850$ worth of soil fertility that was removed from the soil by the twenty crops of wheat. Hence, fifteen cows are able to balance the soil fertility that is removed in growing one hundred acres of wheat.

Combined with dairying, wheat growing can be carried on indefinitely, without the loss of fertility. In other words, interest and not capital is withdrawn in this farm- 
ing operation. Consequently, the full crop-producing power is maintained and an increase of $\$ 18$ in plant food is added to the soil. If twenty cows are kept on this land, the crop-producing power of the soil will be improved to the extent of $\$ 3,000$. Therefore, the farm daily grows in value: it adds quite a little to the capital invested in the plant.

And in this connection a word ahout the saving of this dairy-marle manure is not out of place. For our illustration means that every form of manure produced on the

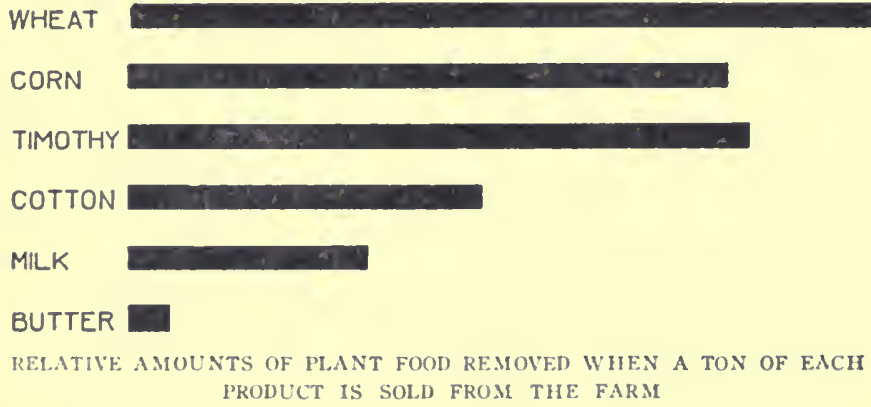

farm must be well preserved, if the fertility of wheat lands-or of any kind, for that matter-is to be maintained.

Waste in the wash of manure.-It the ()hio Experiment Station this test was made and reported hy Director Thorne: manure was taken directly from the stable in April and applied to land about to be plowed for corn. the corn being followed hy wheat and chover in rotation without further manuring or fertilizing, and compared with manure produced ly the same amimals and applied in the same quantity and manner and at the same time, but which harl lain in an open harnyard through the winter. 
The experiments show a loss of twenty per cent. of the total weight of the manure between January and April. The loss in effectiveness is indicated by the fact that the ton of fresh manure produced an average increase in the three crops of the rotation to the value of $\$ 2.94$, while that from the same original quantity of manure, after lying four or five montlis in the barnyard, amounted to but $\$$ I.70, a loss of more than forty per cent.

Chemical analyses made in January and April show that the manure lost between these dates was twenty-two per cent. of its total phosphorus, nearly fifty per cent. of its total potassium, and more than forty per cent. of its total nitrogen; but when the water soluble constituents are determined, it was found that, while the loss of phospliorus retained practically the same proportion, that of potassium amounted to fifty-four per cent. and that of nitrogen to seventy-three per cent.

Losses occur at all times during the year.-It will be observed that these experiments show only the losses that may occur in exposed manure during a few months of the winter, and it is probable that manure does lose in value more rapidly during the first few months than later on, through the leaching out of the liquid, and of the more soluble portions of the solid manure; but these losses do not stop with the winter season, nor are they confined to leaching; but with warmer weather fermentation becomes more active, and fermentation means not only the combination of the nitrogen of the manure with hydrogen and its escape as ammonia gas, but also the conversion of the ash elements into more soluble forms, in which they may be more readily leached out by subsequent rains. The mere loss of total weight, however, is not a safe guide as to the actual loss which may occur in the manure heap. In its fresh condition a lot of manure 
with the usual amount of bedding will be about threefourths water; but as the straw decays and the manure becomes finer its water-holding power increases. Thus, at the Ohio Station, a lot of manure contained in January seventy-scren and five-tenths per cent. water and nineteen and six-tenths per cent. organic matter; in April, eighty-one and seven-tenths per cent. water and fifteen and nine-tenths per cent. organic matter; and in September, eighty-three per cent. water and thirteen and seventenths per cent. organic matter. 


\section{CHAPTER XXVIII}

\section{ROTATION OF CROPS}

"No branch of husbandry requires more sagacity and skill than a proper rotation of crops, so as to keep the ground always in heart, and yet to draw from it the greatest possible profit": so wrote Lord Kames a great

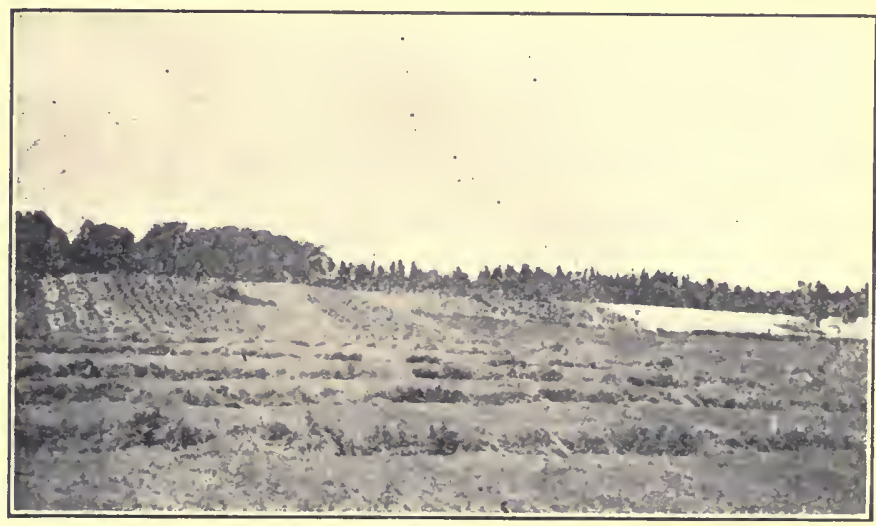

CROP ROTATION

The wisest plan for the maintenance of fertility

many years ago. And with every form of scientific investigation, with all improvements in agriculture-improved soils, better bred plants, more perfected tools of tillage, cultivation, and harvesting-there has come into use no method that contributes quite so much as a wise, well-systematized scheme of crop rotation to the mainte- 


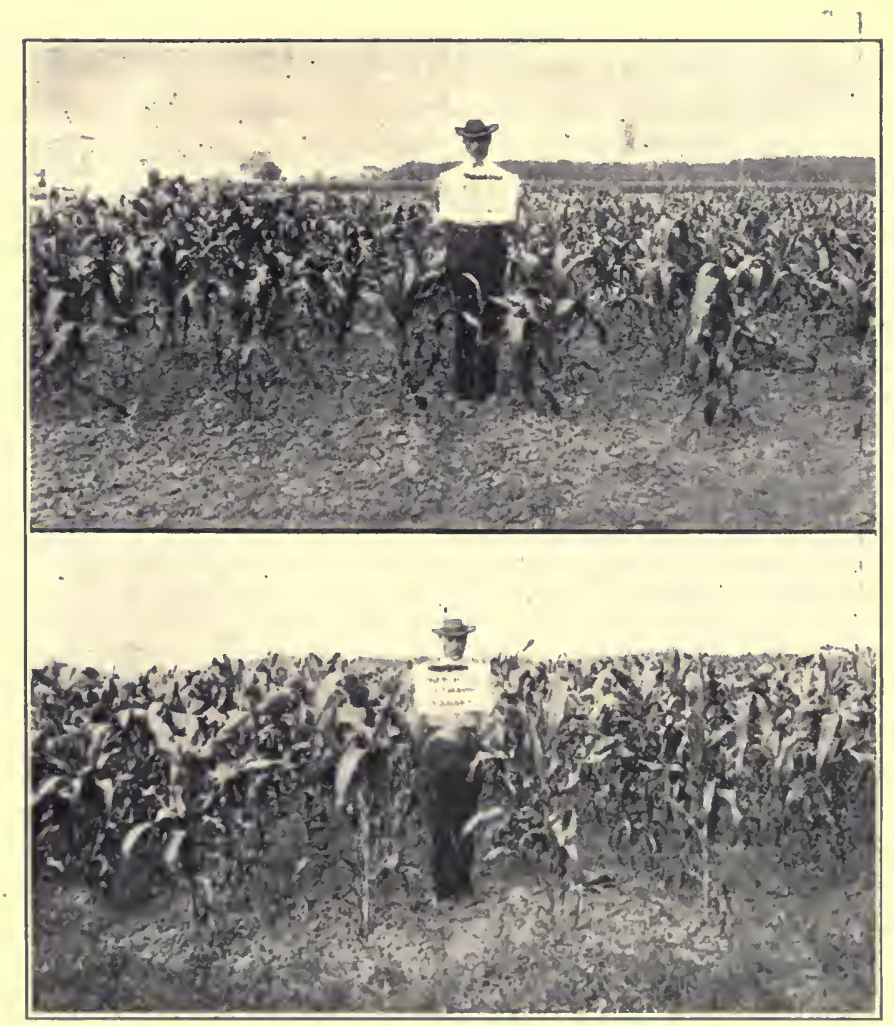

AN FXAMPLE OF CROP ROTATION. CORN IN TIIE. GROWING STAGE

In the upper picture on!y corn has been grown while in the bottom elover has been grown also 


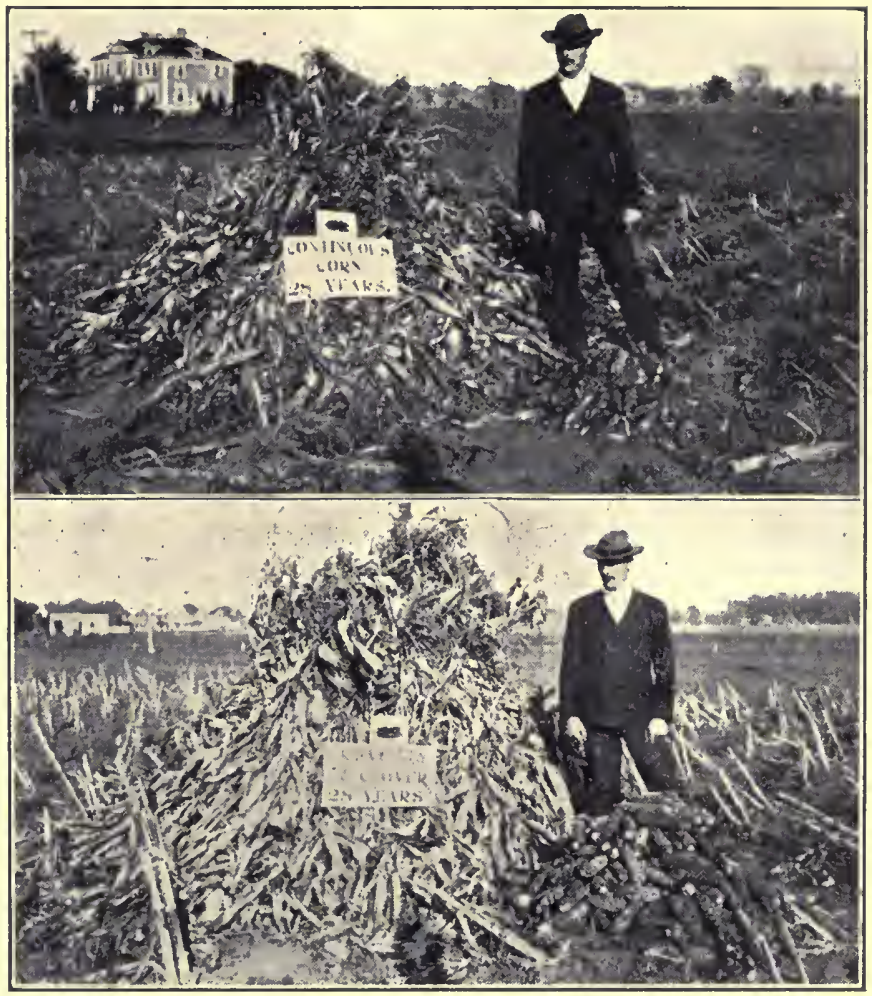

AN EXAMPLE OF CROP ROTATION AT HARVEST TIME

The upper picture shows the result when corn only was grown for 28 years. The lower picture shows the result when corn and clover were rotated for 28 years 
nance of fertility and to the production of maximum and profitable crops.

It is Nature's plan: she favors giving crops fresh lands to grow in. Note the forest: when trees are cut, new and different kinds grow in place of those removed. Note the grass: timothy and clover may grow abundantly, but in the end Bermuda (in the South) and blue grass drive both away. Note the cultivated crop: corn does better after clover or alfalfa, wheat after corn or potatoes, cotton after cow peas or grass, than either crop after its own kind.

A soil is severely injured when a cultivated crop like corn or cotton is grown on it year after year. Even wheat or oats, timothy or cow peas (when cultivated) bring about the same ill-effect. The humus is burnerl out, the soil hardens and deadens, the elements of plant food, especially needed for these special crops, become scant. Hence, the soil loses its power to successfully produce the constant crop. You can correct this trouble, to a great extent, by a change of crops.

A few principles that enter into the scheme of crop succession are:

Plants place their roots differently in the soil.

All plants exhaust the soil.

Plants do not exhaust the soil in the same manner.

All plants do not exhaust the soil erpually.

Some plants add nitrogen to the soil.

Some plants act favorably to weerl growth while others do not.

Plants, grown constantly on the same land, favor the sprearl of insects and diseases.

Feeding habits of the crop.-It is well to pay attention to the feeding habits of a crop). "The shallow feerler ought not to follow a crop having a similar nature: it ought to follow a crop whose roots penctrate deeply into the 
ground. Thus corn, a relatively shallow feeder, should follow clover, a deep penetrator, or some crop like it that sends its roots down deep into the soil. This plan gives the deep grower an opportunity to strike deeply into the soil: to open the tightly bound subsoil, that air and water may get in to release plant food and to hand it over to succeeding crops. For this reason land

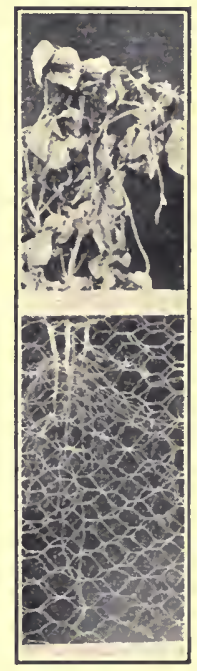

COW-PEA

ROOTS

They secure nitrogen, and at the saine time subsoil the land seeded to a crop like clover makes fine wheat, corn or cotton the next season.

Study the feeding habits of plants, then. Study their roots: learn where they grow, how deep they go. Do they plunge deep into the soil? or do they skim along in the surface layer near to air and light? Ask these questions and investigate. The knowledge is practical ; it is light upon a basic principle of successful farming; and in the future the root systems of cultivated crops will get more attention and study than the past has allotted to them.

Plants vary as to taste.-There is a wide range in kinds of foods that plants fancy. For instance, the potato relishes potassium in abundance; corn and wheat do best when a great deal of nitrogen is in the soil; all grain crops must have much phosphorus and potassium to make well-filled heads. So crop rotation enables each crop to find its favorite dish. All of the legumes get their nitrogen from the air; they also send their roots down into the subsoil, where the mineral elements are, and these the roots gather up and bring nearer to the top. The crops then are harvested just in time for other crops; for in- 
stance, wheat if in the fall and corn if in the spring. Every crop that follows a legume likes the nitrogen that has been stored in the soil by it. It likes, too, the stubble and roots that were plowed under for the humus and for food they provide. It matters not the kind of crop: it is benefited by the legume, for little nitrogen was used and the roots fed and grew in a different layer of the soil than their predecessors. If corn or wheat is sown, some other crop can follow it; it can be the same or a different legume again, or it can be cotton (if in the cotton belt) or oats or alfalfa or potatoes: just whatever fits best into the scheme or what is most needed for your style of farming.

When you give consideration to each crop in this way, you help both the crop and yourself; you help the crop by allowing it the kind of food it likes best; you help yourself by getting more profit from the better yield secured. And this is good farming: to study your crop and to get its confidence.

All plants exhaust the soil.-Since plants exhaust the soil, it is evident that continuous cropping with no commensurate returns leads to a depleted condition of the soil. The mineral elements, you know, come from the soil and from the soil only.

Continuous cropping - the same crop year after yearcalls for certain elements constantly: but it is a very tiresome affair. Of course, if the supply be maintained, or if there be an incxhaustible supply of mineral elements in the soil that never lose their availability and never become carried away by drainage waters, and never get locked into insolulble chemical compounds, and if humus (the very life of the soil) be not burned out, then it may not be necessary to rotate crops.

But the case is otherwise, as New England well knows; 


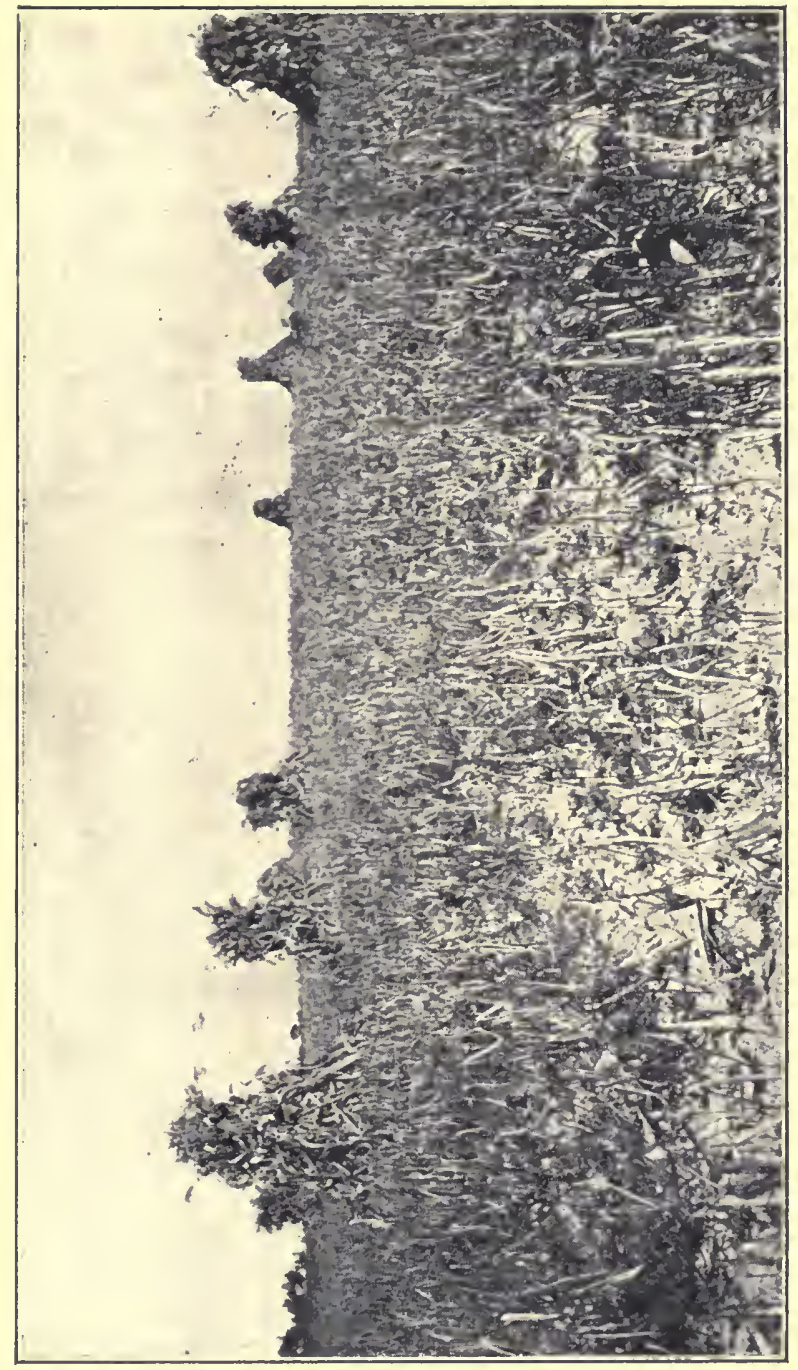

$\frac{0}{\stackrel{0}{0}}$

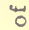

$\stackrel{n}{\infty}$

兵

○

$m$

iี

4

c

$\approx$

(1)

$2-1$

(1) 焉

प्रे तो

का क

(x)

(I)

$\rightarrow$

$\infty$ -

क $E$

(4)

두 $\frac{1}{n}$

$\geqslant 3$

0 :

(ए)

눈

$<\geqslant=$

7 ऽ

2

둉

$0 \geqslant 0$

당

c E

8 눙

0

$< \pm$

द 
as the South with her depleted cotton and tobacco lands testifics; as the West learns as the wheat ficld moves still farther West, depleting the land as it goes, finally to forsake it and to leave its rescue to clover and dairying and diversified farming.

And so it is throughout the world: the progress of vegetation tends constantly to impoverish the soil, unless crop rotation is permitied to adjust the unhappy condition. Where crop rotation is practiced, the lemand on a particular element is met with a less demand by a different crop. For example, alfalfa gets its nitrogen from the air, but feeds heavily on potash: and corn, coming after alfalfa, feeds largely on nitrogen which has been accumulated in the soil during the growth of the alfalfa; but the potassium which alfalfa largely uses is less in demand by the corn plant, and lience there is a readjustment by the rotation: a readjustment such as Nature can handle without denying any element to any crop.

All plants do not exhaust the soil equally.- And so we get this principle: all plants do exhaust the soil, but they do not do it equally. Thus some plants get their nitrogen from the soil only, others get it from the air. Some plants, like potatoes, use a great real of potassium; and others, like corn, a less amount. Our grain crops use a great deal of phosphorus, a great deal more than the potatoes or the legumes. And so all along the line. W'hile this range is not so great as one might think, still, it is sufficiently large to make one-crop farming a barlatoms treatment to the land.

In this connection it slould be said that a wiselyplanned crop rotation includes a legume somewhere in the scheme, that the nitrogen supply mat be maintained with no shortage at all.

Take the practice that is getting into favor so generally: 
the planting of cow peas at the last cultivation of corn. At such a time and in such a place in the rotation peas can be planted without additional expense in labor or team employment; the peas grow abundantly, make forage for live stock, and add nitrogen to the soil. When matured, the peas may be gathered for seed or feed or they may be left on the land.

In North Carolina a crop of corn on poor land yielded thirty-eight bushels of shelled corn per acre, and from a planting of cow peas at the last cultivation twelve bushels of cow peas were picked, worth, at current prices, $\$ 1.50$ per bushel. Besides the yield of corn, there was secured also a pea crop worth, at the lowest figure, $\$ 18$ per acre. When the peas are allowed to die on the land, the stores of nitrogen that are put into the soil by growing this wonderful crop become very large in a very few years. It should be your aim and your purpose, therefore, to include in the rotation some legume crop for the nitrogen it controls.

Rotations are bad for weeds.-Then we should have the help of some good rotation for its effect in weed extermination. Weeds and good farming never go together. Crop rotation is one of the best weapons with which to fight weeds. There are certain crops that affect certain weeds differently, and different tillage tools incidental to their culture enter in. The grain crops allow certain kinds of weeds to flourish, since there is no intertillage to keep them down. Many rapid-growing crops shade the ground and make life such a struggle to certain weeds that they soon despair in the race and disappear.

Elsewhere is stated a case where corn was grown, a yield of more than eighty bushels per acre of shelled corn being secured when weeds were kept out and frequent cultivation given the land. An adjoining plot of corn, where 
weeds were permitted to grow and no cultivation was given, gave a yield of but seventeen bushels of shelled corn per acre. Why this difference? The old explanation is: weeds must be kept away else they will get water and plant food that should go to the cultivated crop.

And now we are told that weeds crowd the root territory of the cultivated plant, and that they produce a toxic effect in the soil, both being especially distasteful or hateful to the more refined and delicate and tender crop. Be the cause of enmity between cultivated crops and weeds what it may, every bit of evidence points against any favor being shown weeds. The whole trend of effort is toward the banishment of weeds.

Do plant roots throw off wastes?-A new theory has been advanced within the last two or three years, one that claims that all plants excrete waste products through their roots. According to it, no plant should be grown on a soil for any great length of time, else the plant excretions will accumulate in the soil faster than the soil can rid itself of them. Time is needed for making away with the excretions of the old plant or crop. When this is done, the soil is made more sanitary and more congenial to the new crop.

In this connection, then, a manure or fertilizer or other material that helps the soil is used, not because it supplies plant food, but because it assists in renovating the soil of waste products and in securing a more sanitary condition of the soil. Hence, fertilizers and manures become soil helpers by renovating and removing the excreta of the previously grown crop.

Now, it loes not make much difference in just what direction you must go for the true explanation of poor soils; but whether you take one or the other, you find 
good soils closely linked with good rotations and poor soils with poor rotations or a single crop.

Getting rid of insects and diseases.-Still another reason for crop rotation is to keep the land rid of insects and diseases. Grow a crop year after year on the same land and you allow insects and diseases to accumulate and spread. Rotate crops, on the other hand, and insect or disease gains little headway, or disappears altogether.

The right treatment of disease and of insect lies in a close crop rotation. Follow it and neither fungus nor insect can destroy your crop; follow it and your reward will be found in a plenteous harvest.

Rotations may vary with different fields.-You may be able to plan a rotation that will serve for all of your fields; many farmers are able to do so. Still, such practice is not essential, and it may be wiser to adopt many rotations-one for each type of land. If you have hill land as a part of your farnı, get a rotation that suits such land; get another rotation that suits your bottom land. Make your rotations bend to the needs of your land and to your returns rather than allow either to bend to the rotation that may be fast bound, provincial and stupid when applied to your entire holdings. I know a field that has been given to a short rotation in which corn is grown every other year, and this field is more productive than it was fifty years ago. Clover and manure have been the treatment needed for the work. Yet it has been shown by actual field practice on the same farm that a different rotation, although clover and manure are both used, is necessary for other fields.

And so it goes. You may like a certain field for pasture because of water, shade or other advantage; and if so, get a rotation that admits a long pasture period and short periods for corn or wheat or cotton or clover or other 
crop. If you have a field especially, adapted to your money crop, use the field for the purpose, but adjust it to a rotation that maintains the fertility - that even increases it.

In the rotation when to apply barnyard manure.-Some prefer barnyard manure for the leading money crop, and that is good practice. But other things may enter into the problem. Where much barnyard manure is made, and where a pasture or grass crop precedes some money crop, like corn or cotton, it is well to apply manure to

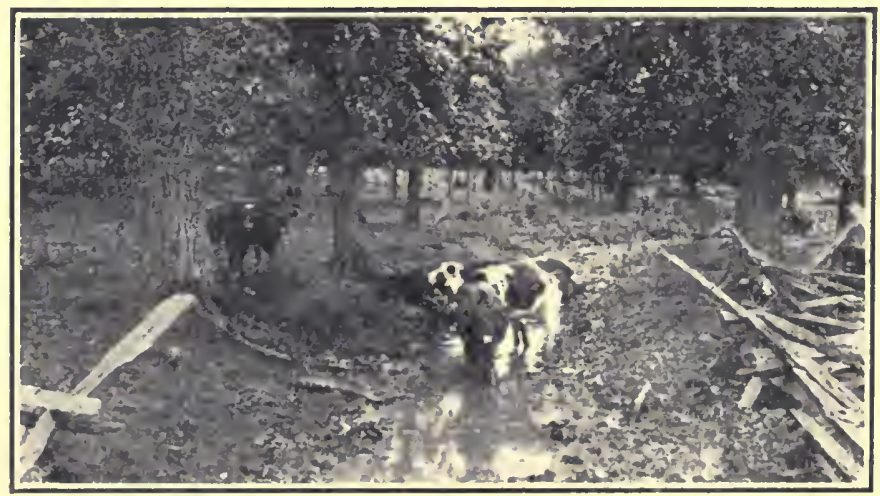

CROP ROTATION AND MIXED FARMING GO IIAND IN HAND

the pasture land, spreading as made and applied. This is the casiest way of handling the manure also. Every season of the year finds the pasture ready, and not only is the pasture improved, lut the money crop following it gets its full value just the same.

A good many years ago Yecldes wrote: "A pasture treated in winter to raw, minermented manure will be so strong in grass, and the soil will become so rich, that, whether plowed the following spring for wheat or after 


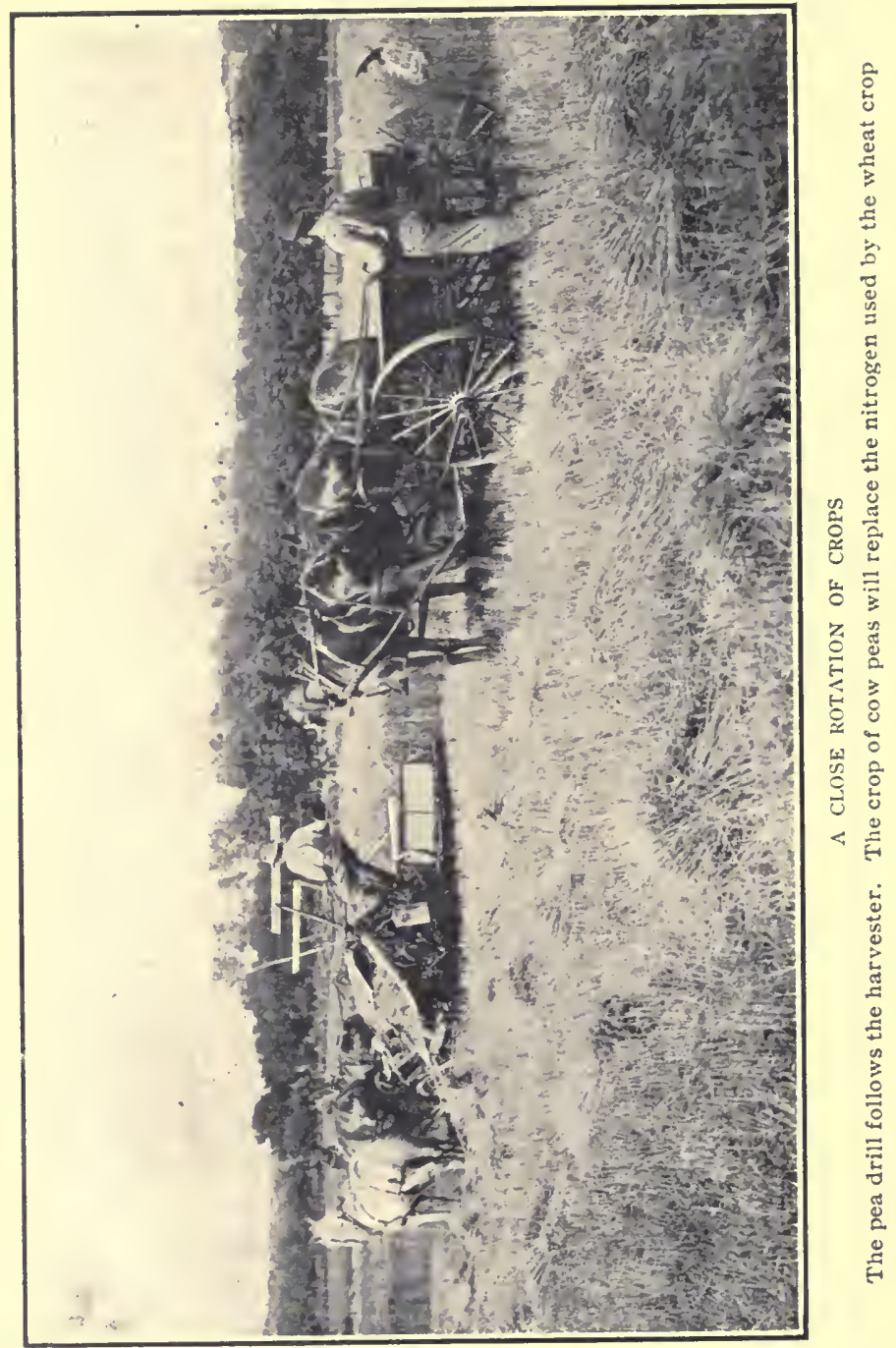


being one year grazed and then put to corn, the maximum yield may be reasonably expected. This winter manuring costs the least of all methods, and probably saves the most of the value of the manure of any known to me."

Crop rotation and mixed farming go hand in hand.There are kinds of farming where mixed farming is not practical, trucking and market gardening being examples of farming systems that are not concerned with live stock and, hence, with crop rotation except to a limited extent only. Then, too, there are sections where the plow cannot be used at all. And so these lands may be given over to trees and to pasture. But the greater part of the country is adapted to the production of a great variety of crops, and to the support at the same time of large numbers of live stock. Wherever the latter conditions prevail, the land, if otherwise treated properly, will maintain its fertility and continue the production of remunerative crops.

These things being true, it follows that live stock and mixed farming should not be disconnected from special lines of farming. The cotton farmer needs cattle and sheep and hogs to consume his cow-pea forage, his clover forage and his corn forage that were produced as a part of the crop system to maintain the cotton lands. The wheat farmer needs live stock for a proper utilization of straw and clover and alfalfa, that are a part of good wheat farming. The corn farmer needs hogs and cattle to consume grain and stover and the rotation crops, that his lands may remain fertile and his farming plant made better. Humus and manure must be had. They may come from green crops or from city stables, but their use must never be ignored, else the time will conse suddenly when neitler chemicals nor tillage will avail and when the land will be thrown back on Nature for restoration 
and for a renewal of life. Then crop rotation is renewed, diversified farming follows, and the land becomes fertile and productive again.

Some well-tried rotations.-There ought to be many kinds of rotations, for rotations ought to suit the farmer, the farm, and the district. Hence, no tight-bound rules should prevail at any discussion of this subject.

In suggesting a few rotations, it is for the purpose of suggesting that they be modified to suit individual con-

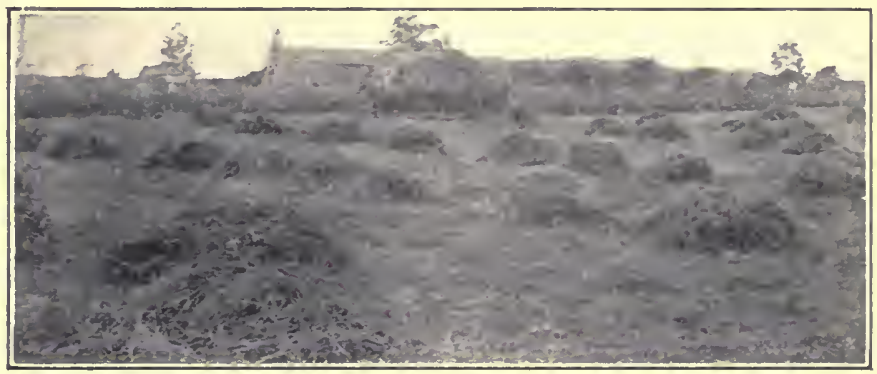

TIMOTHY MAY GO IN ROTATION

But then a good deal of plant food is removed, and the food value is below either clover or alfalfa

ditions as nearly as possible, but, above all, for the rotation you ought to keep in mind these things:

There is to be a money crop.

'There is to be a cultivated crop.

There is to be one or more legume crops.

There is to be live-stock feeding crop.

Rotations planned on these principles are certain to - secure the most satisfactory results only. Take this old rotation-wheat, clover, potatoes. Here is what you have: Two money crops-wheat and potatoes; a cultivated crop-potatoes; a legume crop-clover; and two live-stock crops-wheat, straw, and clover. 
Take this old rotation-corn. wheat, clover, grass-a four-year rotation. It may be modified by being in corn two years, or in wheat two years, or in grass for mowing or grazing two years. Still, it is the same; it meets the four conditions-money crops, the cultivated crop, the legume crop, and the live-stock crop. Why have you no plan in operation that secures to your land a change in crops? The power is in your hand; who shall hinder you from using it? 


\section{CHAPTER XXIX}

\section{THE OLD, WORN-OUT SOILS: WHAT MAY WE DO FOR THEM}

Maybe some of your tillable land is unproductive; it does not give you good crops: it often fails in rewarding you with returns commensurate with the labor and expense you have bestowed upon it. You may be dejected and despondent over the outlook. You wonder does it pay, and the question comes, the same one again and again, What may I do to change this state of affairs? How may I restore these lands, now so unresponsive and so unattractive, to their old positions for doing things-of raising crops that shall be worth the effort, the labor, and the expense?

Just take comfort in this: you are not alone in your troubles; your difficulties are not visited upon you only; your lands are not the sole examples of their kind, requiring much and returning little. All over the country their like exists-worn out, depleted, exhausted, almost dead.

But here is the comfort: These soils possess possibilities and may be restored to high productive power, provided you do a few simple things. You will be rewarded most richly if you do these:

I. Improve the physical life of the soil.

2. Call tillage into service.

3. Get humus into the soil.

4. Keep live stock from tramping and injuring wet lands.

5. Come into close contact with every sort of manure.

6. Grow legumes constantly. 
7. Let green manures help.

8. Rotate crops on the land.

Improving the physical condition the first step.-You will make no mistake in giving prominence to the physical improvement of the soils. It is the first step needed in the work of rejuvenation. A soil offers little when its

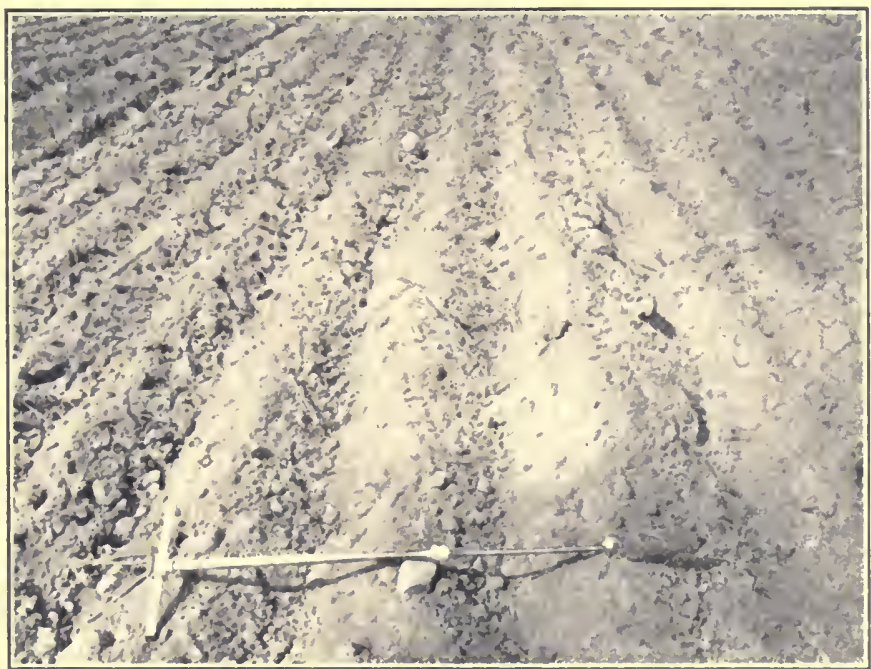

IN I'ERFECT CONDITION

The seed-bed has been made well and the mulch is holding the water for the crop

physical life is at a low chb. A plant can give you but a small harvest if its soil home is clistasteful to it. Just remember these two facts. It may be you will fund your whole trouble located here. lianish the tromble and your question may be answered, your problem may be solved.

I have suggested heretofore what may be done in helping these ofd, depleted lands. It rests with yout to diagr- 
nose the cases as they come up and to prescribe the remedy. If they require drainage, it is to your profit to drain them. It is likely that nothing else will avail. Certainly, stiff, wet soils are useless to you for many kinds of crop. You gain nothing by postponement-you lessen your income only. If any of your soils are sour, then sweeten them with lime, and put them in fit condition for plants that would do their best if their home environments were only such that they might do so.

Call tillage into use.-You should be thinking of tillage much of the time. It should occupy a large place in your thoughts. It should be a sort of human connection with the soil.

Here is an old story:

Once upon a time an old man who was dying called his sons to his bedside and told them in whispers that in the garden a treasure was hidden which, if they would dig diligently, they would find. The sons could hardly wait to bury their dead father before thud, thud, thud, their picks were going in the garden. Day after day they dug; they dug deep; they dug wide. Yet of treasure of silver or gold found they none as they feverishly searched. But still no treasure was found.

"Our father has deceived us," one said.

"Let us not lose every bit of our labor; let us plant this pick-scarred garden," said the eldest.

So the garden was planted, and in the fullness of time the earth yielded up her increase; and when it was seen how wondrously bountiful was the harvest-and so unexpected-the father's meaning dawned upon them. "Truly," they said, "a treasure was hidden there. Let us seek it in all our fields."

The story applies to-day as it did when it was first told. 
Deep breaking of the soil, frequent and intelligent tillage-these are the foundations of soil restoration.

Do you send your plow deep into the soil? Perhaps deep tillage is the sort of medicine your land needs. If you have been accustomed to plow shallow, just try this plan: the next time you plow, set your plow in such a way that it will go deeper into the soil-at least two inches. And the next time go two inches more; and continue to do this until you get a plowed body of land at

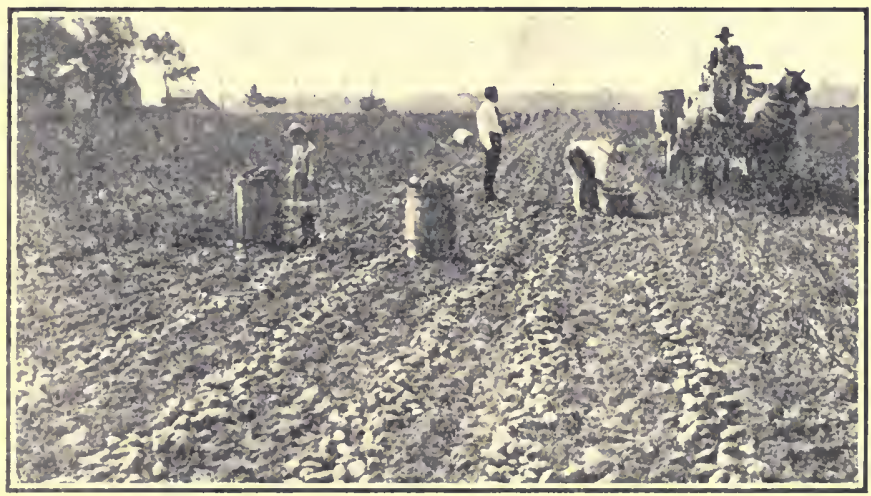

WIIT HUMUS IOOES IN THE SOH,

least nine or ten inches leep. You better to this work gradually, for you night injure your land by turning to the surface a quantity too great to be purified and aerated in a single season. Combine with this gool plowing the most thorough sort of culture; use every sort of preparation tool that is needed to secure gool tilth and a grood seed-bed. Thomas Tusser long aro expressed the meaning in a quaint couplet:

Good tilth brings seeds, IIl tilth, weeds. 
Soils that are plowed deep never wash away; gullies and ditches seldom wrinkle and disfigure where the plow is intelligently used.

Get humus into the soil.-Another step in soil improvement is taken when humus is got into the soil. You can never farm successfully without the co-operation of humus, for it is the backbone and the life of the soil.

You have many ways of securing humus, but stable manure is best. It offers a big opportunity in this direction. It even comes to your very door. I doubt if you use it to the very best advantage, so few of us do.

The old saying that runs,

No grass, no cattle;

No cattle, no manure;

No manure, no grass.

applies to every American farm to-day. The cry of a great majority of farms is for more manure and for better preserved manure, that shall be applied to the soil more intelligently and more thoughtfully than is now the case.

In some parts of the country stable manure is never used; it rots and ferments and finds its way into the air and streams to be lost forever to the soil and world. And what a loss of wealth! Just bear in mind that a day of reckoning will come, and if you have been guilty, either you or your children will have the penalty to pay. No plea will protect and none will save. Rob the soil of the humus already containeri in it, deny admission to the humus rightly belonging there, and the earth will become sullen, stubborn, unkind; it will be unproductive; it will refuse to yield forth its income.

Live stock tramps the land and injures.-A great injury is done every soil when live stock is given liberty and freedom over it, and especially when fall and winter and 
spring are on with their wetness and cold. Cattle tramp the land. They crush the soil particles together, drive the air away, induce the formation of clods and holes; they deaden the soil; they drive life away. Why allow such treatment anyway? Is it necessary? Must cattle be given dominion over the entire farm? Certainly not. Cattle have no place in fields, cultivated or grass lands during the winter months. Their place is in stables, or in barnyards, or in feeding lots, but not in the fields.

Never neglect a manure of any sort.-You should never neglect a manure of any kind. Surely not the home-made sort. Make a lot of manure on your farm. Get cattle; get all kinds of live stock. Sell your crops through them. Never go to a single line in crop production. It means inefficiency; it means soil depletion; it means a worn-out farm.

Study these problems of soil building. Ascertain if your land is lacking any special element. If you are convinced that such is the case, then purchase the needed element and add it to your land. W'ith a small effort in the line of experimentation given you nay learn some valuable lessons that may produce wonderful results.

Grow legumes constantly.-Nothing helps old, wornout soils more than the legumes. They give nitrogen and humus, and they open the subsoil to air and water. Clover and cow peas come first. Either one or the other will grow in your climate and fit into your work. Take the cow pea, for instance. It is an a(luniral)le plant for a depleted soil. Though poor tillage be provided, though the soil be hard and dead, the cow pea will respond with a luxurious crop. Look into the soil and you will fincl the evidences of the little fairies that dicl the work-the bacteria and their tubercle lomes-gathering nitrogen for the plant and leaving what was unused in the soil for the 
following crop. But this first cow-pea crop may not be what you like to see; it may lack vigor and aggressiveness. But just wait, and the next year repeat the workuse the same crop over again. Now you will see a difference, for the bacteria have increased sufficiently to meet all the demands. Now you get your reward! Now you become a friend of the cow pea! And the same is true of all other legumes-of the clovers, of the soy bean, of the vetches, of the alfalfa.

You should use these legumes in every kind of rotation-a legume every year if possible, and cow peas in

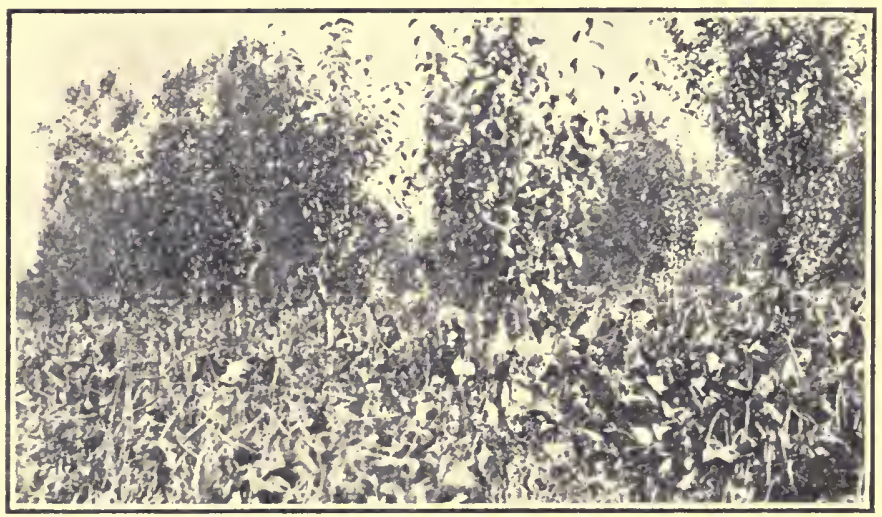

GROW LEGUMES CONSTANTLY

every crop of corn, using the last cultivation of the crop as the seeding time for the cow peas. This is a practical way to do this, so practical that thousands of farmers in all parts of the country have adopted it. The author harvested thirty-six bushels of corn and twelve bushels of cow peas from a field a few years before abandoned and forsaken because of its worn-out condition, which has 
been restored to high productive powers in just the way herein described.

Let green manures help.-Some soils are so completely devoid of humus it often is best to center the first effort in humus supply to them. This may be done by the use of green manures. You may have to pick your crop. For the reason the soil is so poor it may refuse to do much. You had better use the cow pea for this purpose. It seldom will fail. Use a bushel of seed per acre, applying them broadcast. When mature, plow under, turning the soil an inch or two deeper than the previous preparation. The following season either disk the land or replow and sow the second crop of cow peas, using the same quantity per acre and seeding broadcast.

This second crop will tempt you greatly; you will be inclined to harvest it as hay. liut it will pay you to remain firm to your original resolution; let it mature and be plowed into the soil, where it is needed for the nitrogen it holds and for the humus locked in its rich tissues.

The old soils deficient in fertility it will pay you to assist. Iclp the soil and crop through an application of fertilizers. Something like this will do: Mix acid phosphate and liainit together- -500 pounds of the former and 500 pomnds of the latter. ()f this mixture use from 200 to 400 pounds per acre. depending upon the productive power of the soil. IIthe this treatment griven, your old soils will soon be on the way of recovery; they soon will be available for all sorts of crops.

Rotate crops on these lands.--Now, lo nut neglect crop rotation. Remember that this negleet in the past was one of the reatsons why your sorils becane worn out and exhausted-one reason why they became "run down." Surely you do not want this to happen a second time. Crop rotation will largely help, in preventing such a con- 
dition. It matters not what money crops you grow, give your soil a change. Introduce legume crops frequently and constantly. They will keep nitrogen and humus in the soil; they will keep the soil mellow and friable; they will open the subsoil to other roots; and they will save the land. 


\section{CHAPTER XXX}

\section{CONCLUSION: A BIT OF PHILOSOPHY}

We have now followed the progress of soil buildingfollowed it in history as men have labored and struggled to deduce fundamental principles and laws; followed it from the time the earliest soil workers and soil makers hegan their work: followed it as the elements of plant food are taken up and converted into luscious and nutritious food for animal and man; followed it as the opera-

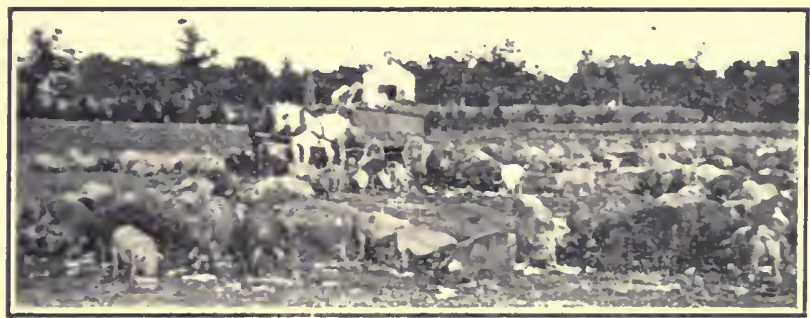

ONE KIND OF FARMING THAT IMPROVES THE LAND

Let your farm be a factory, a farm-factory, where most of the crops raised shall be consumed as feed for live stock

tions of tillage have gone on making the soil better and more productive; followed it as the bacteria, the grood fairies of the soil, have renclered plant fool availahle and air nitrogen assimilable: followed it as water is taken into the soil, and as it is renwered by plant and by inperiect soil managenent ; followel it as sun and air and rain leclp) or liurt: followed it as every implement of tillage and 
culture, work and influence assist in the production of remunerative crops; followed it as every resource is brought into use-the manures of the farm, the artificial plant foods of the commercial factory, the nitrogen of the leguminous plant; followed it as old lands are redeemed and restored to life and productivity; followed it as all agencies and factors that improve and maintain are set at work that the greatest good may result.

And yet the true philosophy of farming and soil management is expressed in the few simple words of Lockhardt: "Good farming consists in taking large crops from the land, while at the same time you leave the soil in better condition for succeeding crops."

The true philosophy of farming is correct handling of the soil that abundant vegetation may be produced.

A story is related of a celebrated English general who had charge of his country's troops in a colonial land, and who was criticised for the attention he gave to the growing of crops in that country.

"General, it seemis to the IIar Department that the thing that most concerns you is the growing of forage for bullocks."

"Yes, sir," the general replied: "that's the principal thing in carrying on a successful warfare in India or any other country. If we have the forage we shall have the bullocks; if we have the bullocks we shall be able to support the men; and if our men be well supported we shall have no trouble in conquering the enemy."

The goal of soil treatment: better crops.-It is indeed a worthy goal that we have-to so treat and handle our soils that we may grow better crops; to ally ourselves with the movement of increasing the food supply of the world; to join laands in the service, that higher living may be possible. Or to accept, in truth and in fact, as a part 
of our efforts, the noble words of Jethro Tull, the Father of Tillage: "Men of the greatest Learning have spent their Time in contriving Instruments to measure the immense Distance of the Stars, and in finding out the Dimensions, and even Weight of the Planets: They think it more eligible to study the Art of plowing the Sea with Ships, than of tilling the Land with Ploughs, they bestow the utmost of their Skill, learnedly, to prevent the natural Use of all of the Elements of Destruction of their own Species, by the bloody Art of War. Some waste their whole Lives in studying how to arm Death with new

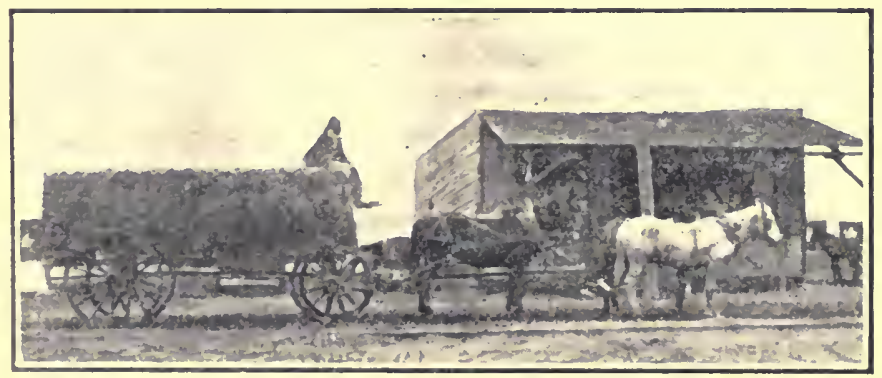

A SURE WAY TO RUIN THE FARM

It is impossible to estimate the enormous quantity of fertility that has been sent from American farms in baled bundles

Engines of Horror, and inventing an infinite Variety of Slaughter; but think it beneath Men of Learning (who only are capable of doing it) to employ their learned Labours in the invention of new (or even improving the old) Instruments for increasing of Bread."

We must keep the fertility up: we must annihilate the soil robber.-Just go into any old section of the countryinto New England, if you please. There you find many deserted homes and abandoned farms. Why? Because the fertility was sold and none replaced. It was sent away 
from the farms in bushel baskets, in baled bundles, in cotton sacks-by the pound, by the bushel, by the ton. Go into the South-into the land blessed in every way beyond measure. You find impoverished soils; you see worn-out fields, gullied and wrinkled and cast aside. The fat of the land was gathered up and shipped away in cotton, in tobacco, in corn, and none was returned to take its place. The humus was used up and burned by onehorse plows and shallow working tools and the land was bereft of its powers of high production.

Go into any of the older portions of the country-go even into the West, into the newest settlements. You find depleted soils, lands robbed of fertility, farms rendering their owners a bare existence. Why is this all so true? Because the soil robber in every instance had been present, and because of a compact with the fool the fertility has been taken away and the lands reduced to the lowest point of production.

But the brighter side of the picture is coming into view; we see the soil robber and the fool far in the distance, disappearing; we see the intelligent tiller of the soil in the foreground, already at work with vim and courage and determination, adding humus to the soil and restoring life to the land. And so every earnest husbandman can take courage, for the land is not lost to the wise farmer-either East or West, or North or South. For brains mixed with the soil and applied to intelligent culture will restore the land and save the nation.

Diversify your crops: have many to support you.-It matters not what your line of farming-your specialtymay be, you must have the help of many crops. Is it wheat? You need clover and grasses for humus and nitrogen. Is it corn? You need animals to consume it that the manure may be returned to the land; you need 
clover and alfalfa as preceding crops to corn. Is it cotton? You need cow peas to subsoil the land, to get all humus that is needed, and to provide the costly nitrogen; you need the clovers and the cereals to feed your work stock and to prevent the washing of the soils by the winter rains. Is it potatoes, or truck, or a cultivated crop of

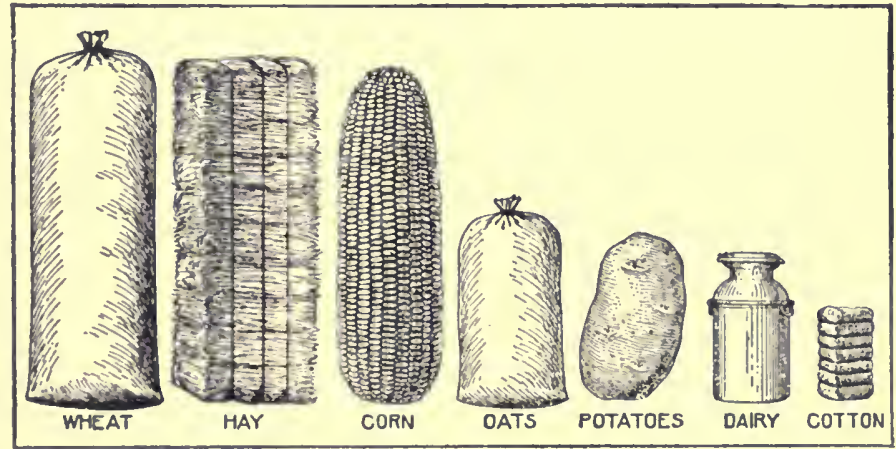

SEVEN OF OUR LEADING PRODUCTS

When sold off the farm just so much plant food is sent away. The relative proportions are shown above and apply to nitrogen, phosphorus and potassium in a ton of each product

any kind? You need, just the same, cow peas and clover; you need a variety of crops.

All these things you need, not for the land's sake only, but you need them as agents in the support of your business; you need them for the improvement of your farmstead; you need them as contributions in your welfare and happiness.

Be a legume farmer: be up with the times.-In the old days legumes were appreciated, but only slightly used. The up-to-date farmer, who prospers and improves his plant, is now a legume farmer. He uses one or more legrume in every rotation to get all needed nitrogen, to 
add to every nitrogen store, to get the best crops for feed, to get the best yields from other crops that follow.

Do your work well: farm intensively.-Equally as bad as the soil robber is the soil killer-the man who kills and deadens the soil by ruthless methods; who farms large areas by slashes and stabs; who takes and never gives back to the soil; who farms extensive areas but harvests

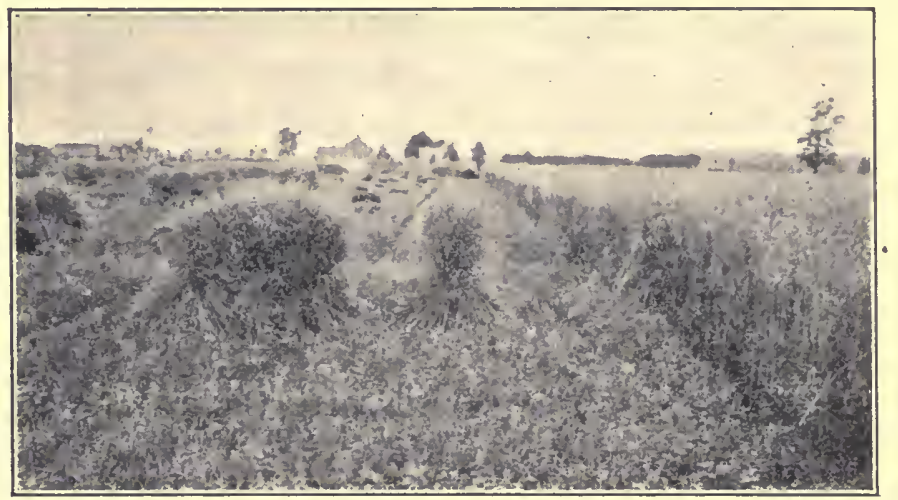

INTENSIVE FARMING

Good tillage, crop rotation and an abundance of humus are all back of this crop

little yịelds. He is in New England, where his hay yields him a quarter to a half ton per acre; he is in the South, where his quarter a bale per acre of cotton is produced at a loss; he is in the West, where his corn is but "twenty" and his wheat but "thirteen"- and neither is grown at a profit.

You cannot afford to be classed with this tribe. Yours must be another caste if you bear any respect for your family or yourself.

Take up the better way, the way of doing things right and square and manly. Farm wisely, that you may be 
a man, a wise man at work with Nature, in sympathy with her laws and decrees. Take the sullen and stubborn soil (rendered so by the bad treatment of your predecessor) and render it so gentle and pliable and responsive that henceforth it will do your will.

Eliminate hand work: use machinery.-The farmer enters into his own at the very moment he realizes that he ought to be educated; when he uses his powers of thought to till his land and to grow his crops; when he uses his muscles less and his brain more; when he spares the physical body and crowds the tool or machine he has created. The effect of the elimination of hand labor and the use of muscle-saving machinery on the plyysical and mental man is soon apparent. Before the coming of machinery this was true, as Edward Markham has said:

Stolid and stunned, a brother to the ox,

He stands and leans on his hoe and gazes on the ground;

The emptiness of the ages on his face,

And on his back the burdens of the world.

While now he rides and directs every sort of machine that is made to do his will, he fittingly represents his highest and loftiest mission. Now he stands as Henry Jerome Stockard sees him:

Imperial man! co-worker with the wind And rain and light and heat and cold, and all

The agencies of God to feed and clothe

And render beautiful and glad the world!

Foremost among the causes that have occasinned this change in physical and mental man, in adding ease, comfort, and length of life, in making possible the nation's wealth and greatness, is the application of machinery to agriculture. 
Consider for a moment the ancient man with his sickle in one of our Western wheat fields alongside a modern combined header and thresher, which takes twenty feet at a "through" and drops the grain off in sacks; and imagine, if you can, how many of these fellows with the sickle it would take to harvest our immense crops of $60,000,000$ acres of wheat. Put our ancient father with his crooked stick for a plow in one of these large wheat fields and count up, if you can, at some idle hour how many like him it would take to do the work of the man who

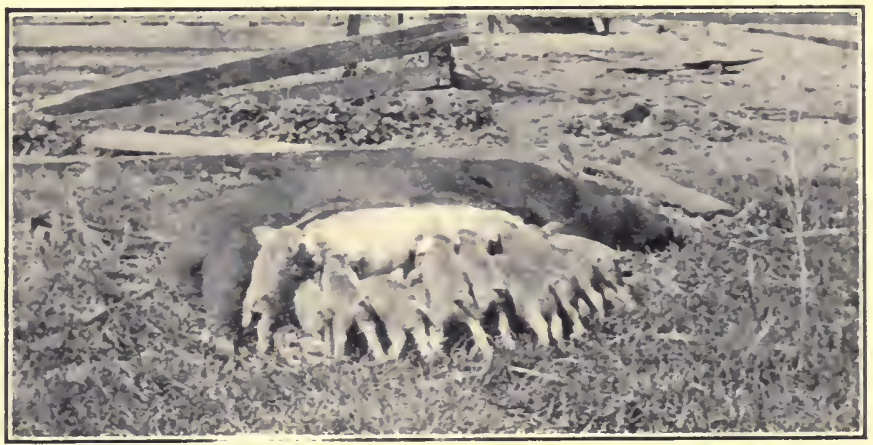

$\triangle$ DEPARTMENT OF THE FARM-FACTORY

to-day drives the modern steam gang-plow at the rate of ten miles per hour, taking twenty-four one-foot furrows at a "through."

If we to-day used the old hand methods and produced our present food supply, fifty millions of people more would need to be added to our population, and all of us would be required in our agricultural fields, and even then we should need to eat sparingly and to fast often, else the day of little harvest might come and we perish altogether. 
Feed your crops to live stock: make the farm a factory. - Let your farm be a factory, a farm-factory, where most of the crops raised shall be consumed as feed for live stock, that finished products may be made and as such be sold, rather than as raw materials, in which form they were raised. Such a system of farming will lead to permanent improvement of the soil ; it will secure from it the highest efficiency. These things it means: that there shall be diversity in crops; that more live stock shall be

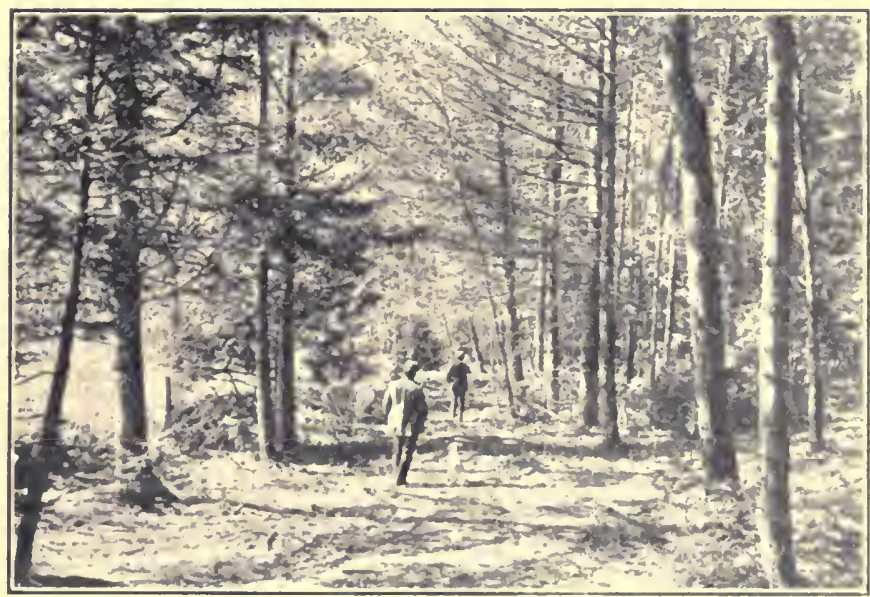

"THRO' WOOD AND MEAD"

bred and fed on the factory-farm: that the entire plant shall be managed as a business enterprise of the largest magniturle.

Study your work and be a man.-Finally, your lusiness opens widest the gates of opportunity for studly and development and right living.

The following words of liberty 11 ycle laiky, as beanti- 
ful as they are simple, as strong as they are true, indicate the ideal of your regal pursuit:

I teach

The earth and soil

To them that toil,

The hill and fen

To common men

That live just here;

The plants that grow,

The winds that blow,

The streams that run,

In rain and sun

Throughout the year;

And then I lead

Thro' wood and mead,

Thro' mold and sod,

Out unto God.

With love and cheer,

I teach. 


\section{INDEX}

Acidity corrected ........... PAGE detceted $\ldots \ldots \ldots \ldots \ldots \ldots \ldots \ldots . . \ldots 104$ Acid-made manures, when to use 75 helps soil-making............ 9

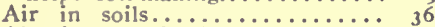

Aluminum defined............. 6 i

Analyses, early faith in...... 71 average soils................... 66 crops ............... 80 determine soil needs......... 71 fail to dctermine fertility..... 72 mechanieal ............ 30 numerous, necessary........ 75 should be extensive......... 75 sliow condition of plant food.. 76 subsoil ................. 76 typical soils............. 27 value of ................... 74

Animals in soil-making......20, 21 Barley, analyses of plant food

80,81 Barn-yards, good and bad..... 2I!

Berthelot ............... 114 Blood, dried............... 231

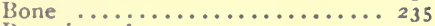

lioussingault ............. I1

Calcium defined............. 60

Calcium in good supply........ so

Capacity of soils to hold water.. 42

Carbon defined.............. 56 dioxide in soil-making.......9, 10 function of .............56, I 8 secured by leaves.......... 45 where secured ............. 45

Cellulose defined............ 50

Chlorine defined............ 58 function of .............. 58

Circulation, air................ 36

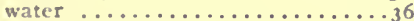

Classification of soils........ 25

Clay soil analysis........... 27 soils modifierl............. 35

Composition of plants........ 45 of soils................ 23

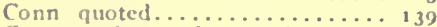

Corn, analyses of plant food..80, 8I 's. dairying ............. $26_{3}$ soil a nalysis.............. 27 yicld in Xinth Carolina....... 274

Cotton z's. dairying........... 263

Cotton-seed ineal.............232

Crops, better................ 292 demanils for forl......... 81 diversifying .............. 294 for various soils........... 31

Cultivation checks evaporation.. 167
Cultivation, PAGE

depth of.........201 destroys weeds............. 199 saves water.............. 172 shallow and deep............201

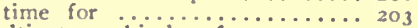

Cultivators, kinds of ............ 199

Culture, level............... 203

Dairying, a balanee in fcrtility.. 261 and wheat compared........ 257 enriches land............. 260 makes fat............... 257 remakes soil.............. 258 vs. grain ................ 255

Decay in soil-making......... 19

Denitrification ............. 123

Disking, value of........... 180

Ditch, digging the.......... 162

Drain, kind of ............. 159

Drainage, admits air......... 154 objeetion to open........... 160 outlet, protect............. $16_{3}$ tiles the perfect............ 16t admits air............... 154 assists manure............ 154 assists tillage............ 156 deepens soil.............. 152 function of ............. 152 lengthens season........... 156 prevents drouth .......... 157 prevents washing............ I58 sanitary effect of........... I 59 warms soil.............. 155 where not needed.......... 159

Drains, depth of ............. 162 distance between........... 161

Drift soils................ I 5

Elements, constructive........ 118 defined .................. 52 how used................ 53 of plants................ 44

Evaporation by sun and wind.. I66 elieekerl ..................167

Farming, dry, defincd........ 178

Fecding luabits of erop........ 269

Fertility defined.............. 5 kecping up............85, 203 more than soil............. 5 not found by analysis....... 72

Fertilizer, amount to use...... 251 analyoses ................. 243 pereentalges ............ 254 problems ............... 252 factory mixed ............. 239 home nuixing..................... 246 to. lam for .............. 249 voluse of ....................

Field tests esscutial.......... 78 
Film, water.................. 38

soil................ 37

Fish dried and ground.......232

Food, available, small.......... 66 forms of plant................ $6_{4}$ how used by plant.......... 50 increased ................ 92 stupply large............. 87

Frost in soil-making.......... I

Glacier soils............... I5

Grain vs. dairying............ 255

Grass lands................. ${ }_{28}$ soil analysis............. 27

Growth affected by soil......... 28

Gypsum ...............99, 100

Harrow, function of.......... 192 kinds of ............... I 93

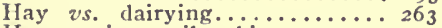

Heat assists soil-making........... I0

Hellriegcl ........... I09, I I4, I 39

Humus affects water flow..... 40 effect of decaying......... 95 effect on soils............ 30 holds plant food............ 66 in soil, get.............. 286

Husbandry, horse-hoeing....... 90

Hydrogen defined............ 54 function of ............ 5.5

Ice helps soil-making........... I 4

Improvement, first steps in . . . . . 283

Inoculation by pure culture.... 149 by soaking seed........... 148 by soil ............... I 48 essentials $\ldots \ldots \ldots \ldots \ldots \ldots \ldots$ r 5 r methods of............... 147 what it means............. I 44

Intensive farming............... 296

Iron defined.............. $6_{\text {I }}$

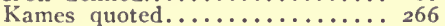

Kainit ................. 237

Laboratory defects........... 73

Lawes \& Gilbert............ 112, 1 37

Leaves secure food........... 45 wither to save water........ 50

Legume farmer, be a........ 295 function of ............. II grow constantly........... 287 increase nitrogen.......... 85 necessary in rotation........ 273 secure nitrogen............. I 36

Liebig ................. I I I, I I 2

Lime affects soil particles...... 103 applying .............. r 105 corrects acidity........... 104 function of ............. ror gas $\ldots \ldots \ldots \ldots \ldots \ldots \ldots \ldots$ rot kinds used ............... 99 promotes good texture........ I02 quantity to use............. I 106 lime-spreader ............. r 06

Liming ................. 99 when to practice.......... 75

Jitmus $\ldots \ldots \ldots \ldots \ldots \ldots \ldots \ldots$ 104

Machinery preferred........... 297

Magnesium defined.............6 60

Manure, accumulative effect of. . 225
Manure, amount to Erf system of to apply...... 224 erving..... 212 grcen $\ldots \ldots \ldots \ldots \ldots \ldots \ldots \ldots \ldots 289$ handling $\ldots \ldots \ldots \ldots \ldots \ldots \ldots \ldots$ 21 influenced by bedding........ 209 influenced by fecd............ 207 influenced by stock......... 209

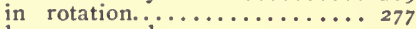
large mound............. 219 losses through year.......... 264 methods of applying........ 218 never neglect............. 287 objections to hand scattering...2 2 I9 preservatives ............ 214 preserving $\ldots \ldots \ldots \ldots \ldots \ldots \ldots 2$ II small piles of $\ldots \ldots \ldots \ldots \ldots \ldots$ 21 solid and liquid............ 2 Io spreader for .............. 220 waste and wash of ............ 263 water in ................ 206 whicn to apply............. 222 whcre to apply........... 223 Markliam quoted............. 297

Marl ................... 99

Metals of plant growth......... 58

Mississippi action on soils....... 13

Moisture in soil-making....... 10

Molasses illustrates osmosis..... 47

Mulching, henefits of ....... 173

IIulch, making effective........ r 74

Nature slow worker.......... 90

New Hampshire manure experiments ............... 225

Nitrification $\operatorname{defined...\ldots .........~} 126$ essential ................ 1 28 when favored............. 75

Nitrogen defined............. 55 fixation............ 109, I 35 , I 40 fixed in soil.............. 35 function of . . . . . gathercd by tubercles......... 137 how lost $\ldots \ldots \ldots \ldots \ldots \ldots \ldots \ldots$ I 33 increased by legumes.......... 85 losses of............... I 22, I 33 more needed................ 1 36 preventing losses of.......... I 34 reclaiming $\ldots \ldots \ldots \ldots \ldots \ldots \ldots$ I 34 secured by inoculation....... I 50 sources of............. II9, 230 where secured.............. 45

North Carolina corn yield....... 274

Oats, analyses of plant food..80, $8 \mathrm{I}$

Ohio station manure experiments 217 manure experiments......225, 263

Organic matter modifies soils.... 35

Osmosis dcfined............. 47

Oxygen defined.............. 53 function of ............ 54 in soil-making.............. 9 where secured .............. 45

Packing, sub-surface.......... I 82

Phosphorus defined........... 57 function of .......... 57, 228 sources of ............45, 233

Potash defined............... 58 function of ............. 60 
PAGE

Potash, muriate............ 237

office of................ 228

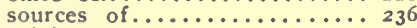

sulphate $\ldots \ldots \ldots \ldots \ldots \ldots \ldots 237$

where secured............. 45

Potassium, function of ....... 228

Plant composition........... 45 food, available..........67, 69 food supply large........... 87

food, unavailable.......... 69

Plants assist soil-making....... I9 demands upon plant food.... 79 exhaust soil............27 in soil-making............. 17 prefer certain soils......... 24 prehistoric .............. 18

Plow, disk................. Ig I gang $\ldots \ldots \ldots \ldots \ldots \ldots \ldots \ldots \ldots$ I9l one-horse .............. 189 work it should do.......... 186 ancient and modern........... 185 various $\ldots \ldots \ldots \ldots \ldots \ldots \ldots$ 189

Plowing, poor, example........ I 88

l'ore-spaces in soil......... 37

Production related to soil texture 87

Protoplasm defined........... 50

Roberts' manure experiments... 223

Koller, function of.......... 93

Root, inethod of growth...... $4^{1}$ wastes $\ldots \ldots \ldots \ldots \ldots \ldots \ldots \ldots 275$ depth of $\ldots \ldots \ldots \ldots \ldots \ldots \ldots . \ldots \ldots$ in soil-making............ 21 sccure food $\ldots \ldots \ldots \ldots \ldots \ldots \ldots .45$

Root-hairs, action........... 47 function of .............. 46

Rotation, destroy weeds....... 274 example for 50 years....... 82 examples of................280 for different fields......... 270 ó manure in .............. 277 on worn land ............ 289 with mixed farming.......... 279

Running out of soils, the cause of 85

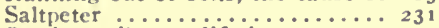

Sandy soils modified......... 35

Sap flow............... 47

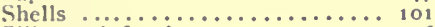

Silicon jefined.................. 56 function of ............. 57

Size of soil particles.......... 24

Snyder's manure experiments... 225

Soda, nitrate.............. 230

Sodium defined.............. 60 function of ................ 60

Sourness in soils.............. 104

Sireader, manure............. 220

Stables ................... $2: 3$

Sinck, feed crops to........... 298 injures soil............... 286

Simbble, managing........... 179

Subsoil defined.............. 4 dliffers irum surface........... g g plant foul froun........... 86

Sulphur defined........... 57 futction of ............. 57

Symbiosis defined............ 140
Tankage ...............

Temperature helps soil-making.. ${ }^{232}$

Texture improved by lime...... I02 improving $\ldots \ldots \ldots \ldots \ldots \ldots . . . . .93$

may be modified............. 35

Thorne's manure experiments

225,263

Tiles, advantages of.......... 161 the perfect drain................ 161

Tillage benefits............ 92 checks denitrification......... 124 destroys weeds............ 97 effect of..............91, 92 increases moisture.......... 96 increases plant food.......... 94 natural ................ 88

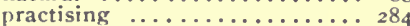

Tobacco soil analysis......... 27

Tools, interculture............. 198 preparation .............. 192

Transpiration .............. I64

Truck soil analysis.......... 27

Tubercles, root.........114, 137

Tull, J...................

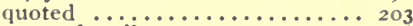

Types of soil.................. 26 of soil, secondary......... 30

Ville ................... 114

Voelcher ................. I 13

Water, capillary............ 40 capacity to liold........... 42 conserving ............. 205 films................ $3^{8}$ gravitational ............... 49 helps soil-naking........... ${ }_{12}$ holding capacity of soils...... 42 holding increased............ 96 hygroscopic ............. 40 incrcased $\ldots \ldots \ldots \ldots \ldots \ldots \ldots 196$ increased by compaction........ 196 in soils, kinds of .......... 40 in soil-making.......... 10, 12, 14 lifts plant food............. 41 passes through soil............ 38 saved by leaves withering.... 50 saved by tillage.........167, 172

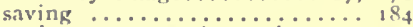
saving means early work...... 204 sorts soils.............. 14 three kinds in soil............ to used 11 by weeds............ 109

Weeds affect water content.... 199

Wheat, analyses of plant fond 80,81 and dairying compared...... 257 continuously grown......... 261 lands .................. 28 snil analyses............ 27 Wilfarth............. 100. 11.4. 139 W'ind liclps soil-making....... is Woll on disirying............ 255 IVork, climinato hani......... 297 IIorn-ont soils not exhansted.. 87 II'orms |relp soil-naking....... 21

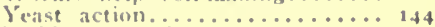
Yeddes, quoted........... 177 




UNIVERSITY OF CALIFORNIA LIBRARY

Los Ar ŗeles

- icnl "TE on" tate stam ' 
S591

B9ls

Agriaitaro

Library 
University of Cailfornia

SOUTHERN REGIONAL LIBRARY FACILITY
405 Hilgard Avenue, LOS Angeles, CA $90024-1388$

Return this materiai to the library

from which it was borrowed.

1.I QL JAIV , o by 
